\title{
WET AIR OXIDATION OF BENZENE
}

\author{
by
}

Basim Ahmed Abussaud

A Thesis submitted to the Faculty of graduate Studies

and Research in Partial Fulfillment of the

Requirements for the Degree of

Doctorate of Philosophy

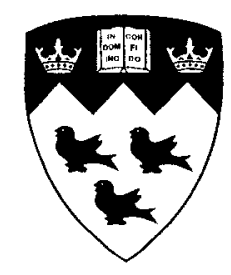

Department of Chemical Engineering

McGill University

Montréal (Quebec)

(C) Basim Abussaud, 2007 
Library and

Archives Canada

Published Heritage

Branch

395 Wellington Street

Ottawa ON K1A 0N4

Canada
Bibliothèque et

Archives Canada

Direction du

Patrimoine de l'édition

395 , rue Wellington

Ottawa ON K1A ON4

Canada

Your file Votre référence

ISBN: 978-0-494-38555-5

Our file Notre référence

ISBN: 978-0-494-38555-5

NOTICE:

The author has granted a nonexclusive license allowing Library and Archives Canada to reproduce, publish, archive, preserve, conserve, communicate to the public by telecommunication or on the Internet, loan, distribute and sell theses worldwide, for commercial or noncommercial purposes, in microform, paper, electronic and/or any other formats.

The author retains copyright ownership and moral rights in this thesis. Neither the thesis nor substantial extracts from it may be printed or otherwise reproduced without the author's permission.
AVIS:

L'auteur a accordé une licence non exclusive permettant à la Bibliothèque et Archives Canada de reproduire, publier, archiver, sauvegarder, conserver, transmettre au public par télécommunication ou par l'Internet, prêter, distribuer et vendre des thèses partout dans le monde, à des fins commerciales ou autres, sur support microforme, papier, électronique et/ou autres formats.

L'auteur conserve la propriété du droit d'auteur et des droits moraux qui protège cette thèse. $\mathrm{Ni}$ la thèse ni des extraits substantiels de celle-ci ne doivent être imprimés ou autrement reproduits sans son autorisation.
In compliance with the Canadian

Privacy Act some supporting forms may have been removed from this thesis.

While these forms may be included in the document page count, their removal does not represent any loss of content from the thesis.
Conformément à la loi canadienne sur la protection de la vie privée, quelques formulaires secondaires ont été enlevés de cette thèse.

Bien que ces formulaires aient inclus dans la pagination, il n'y aura aucun contenu manquant.

\section{Canada}


This thesis is dedicated to my parents, my wife, ellaxam, my daughter \&ude, \&

myron exhumed

whose true love and permanent support have enabled me to achieve the goal Of was after 


\begin{abstract}
Processing of petrochemical compounds produces a large amount of wastewater. This wastewater consists of toxic (hazardous) materials that can not be discharged to the environment without treatment. As restrictive environmental constraints increase, new technologies are needed to treat those toxic materials before discharging them to the environment. Wet Air Oxidation (WAO) is one of these new methods.

This study casts light on the effect of initial $\mathrm{pH}$ on the WAO of benzene at different temperatures and pressures. It was found that at $\mathrm{pH} 6$, a temperature of $260^{\circ} \mathrm{C}$ and a partial pressure of oxygen of $1.38 \mathrm{MPa}$ around $97 \%$ degradation was achieved in one hour. When the initial $\mathrm{pH}$ was lowered to 4 more than $90 \%$ degradation was achieved at $220^{\circ} \mathrm{C}$ and $\mathrm{P}_{\mathrm{O} 2}$ of $1.38 \mathrm{MPa}$ in only 15 minutes. It was concluded that the higher the temperature the better the benzene degradation, and the faster benzene degradation has been obtained with the increasing partial pressure of oxygen. The main intermediates were acetic acid and formic acid.

Furthermore, it was found that the degradation of benzene can be further enhanced in the presence of phenol. The main reason can be attributed to the effect of the free radicals generated from the fast phenol degradation. A simplified pathway for oxidation of benzene was proposed.
\end{abstract}




\section{RÉSUMÉ}

Le traitement de composants pétrochimiques produit une quantité importante d'eaux usées. Composées de matériaux toxiques, ces eaux usées ne peuvent être déversées dans la nature sans traitements additionnels. Au fur et à mesure que les contraintes environnementales augmentent, de nouvelles technologies sont indispensables afin de réduire ces matériaux dangereux; l'oxydation en phase aqueuse est l'une de ces techniques.

Cette étude s'intéresse à l'effet du $\mathrm{pH}$ initial sur l'oxydation en phase aqueuse du benzène à différentes températures et pressions. On note qu'à un $\mathrm{pH}$ de 6 , une température de $260^{\circ} \mathrm{C}$ et une pression partielle d'oxygène $\mathrm{P}_{\mathrm{O} 2}$ à $1.38 \mathrm{Mpa}$, environ $97 \%$ du benzene est oxydé en une heure. Lorsque le pH initial est diminué à 4, plus de $90 \%$ de la décomposition s'est produite en seulement 15 minutes à $220^{\circ} \mathrm{C}$ et à une pression partielle $\mathrm{P}_{\mathrm{O} 2}$ de $1.38 \mathrm{Mpa}$. Ces résultats suggèrent que cette réaction se fait mieux à des températures plus élevées. De plus, une augmentation de la pression partielle de l'oxygène permet d'accélérer le processus. Les intermédiaires principaux de cette réaction sont l'acide acétique et l'acide formique.

En outre, on observe que la présence de phénol favorise la transformation du benzène; ceci peut être attribué aux radicaux libres générés par la décomposition rapide du phénol. Une approche simplifiée pour l'oxydation du benzène a été proposé. 


\section{ACKNOWLEDGMENTS}

Praise and gratitude be to God "he who taught (the use of) the pen. Taught man that which he knew not."

It is a great pleasure to any human being to accomplish the work he devoted to. Yet, it is a pride to human being to remember, in those moments of pleasures, those who contributed to get the work completed.

Therefore, in acknowledgment thereof, I wish to express appreciation to McGill University, College of Graduate Studies and Chemical Engineering Department who granted me the chance and facilitated matters to me to do my $\mathrm{PhD}$.

Also, I would like to sincerely thank King Fahd University of Petroleum and Minerals for the scholarship awarded to me.

Extreme appreciation and deep thanks are extended to my supervisors; Dr. George Kubes and Dr. Dimitrios Berk for their sincere advice, valuable guidance and continuance assistance throughout the course of this work.

Gratitude and thanks are also extended to Dr. Nilgun Ulkem for her assistance and advices.

I am also deeply thankful to Charles Dolan, Alain Gagnon and Lou Cusmich for their help during this work.

Special Thanks to Ed Siliauskas and Ranjan Roy for all the technical assistance they offered during this work.

I also wish to thank all the member of the Pulp and Paper Center at McGill University for their friendship.

Last, but not least, I wish to express my gratitude to my parents for their moral support. Many thanks go to my loving wife, Maram, for her sacrifices, much encouragements, and moral support; very special thanks go to our daughter Jude and son Ahmed for the joy they brought us.

Finally, I extend thanks and appreciation to everyone helped directly or indirectly to get this work done. 


\section{TABLE OF CONTENTS}

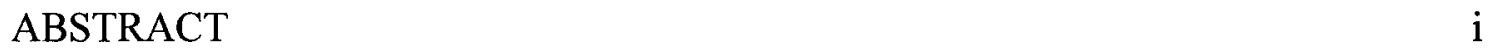

RÉSUMÉ

ACKNOWLEDGMENTS

LIST OF FIGURES viii

LIST OF TABLES Xiv

CHAPTER ONE

INTRODUCTION

1.1 Petrochemical Wastewater Effluent 2

$\begin{array}{ll}\text { 1.1.1 Benzene } & 2\end{array}$

1.2 Objectives 3

1.3 Thesis Structure $\quad 4$

\section{CHAPTER TWO}

\section{LITERATURE REVIEW}

2.1 WAO of Organic Compounds

2.1.1 WAO of Phenol 5

2.1.2 WAO of Formic Acid and Acetic Acid 6

2.2 Free Radical Mechanism $\quad 8$

$\begin{array}{ll}\text { 2.2.1 Induction Period } & 10\end{array}$

2.3 Effect of the Initial $\mathrm{pH}$ on the WAO 11

2.4 Wet Air Oxidation Enhancements $\quad 12$ 


\section{CHAPTER THREE \\ Experimental Setup and Procedure}

$\begin{array}{ll}3.1 \text { Apparatus } & 15\end{array}$

$\begin{array}{ll}\text { 3.2 Materials } & 17\end{array}$

$\begin{array}{ll}\text { 3.3 Experimental Procedures } & 18\end{array}$

$\begin{array}{ll}3.4 \text { Analytical Methods } & 19\end{array}$

3.4.1 Gas Chromatography Analysis $\quad 19$

3.4.1.1 Gas Chromatography Method 20

3.4.1.2 Calibration of the GC 21

$\begin{array}{ll}\text { 3.4.2 Ion Chromatography } & 21\end{array}$

3.4.2.1 Ion Chromatography Method 22

3.4.2.2 Repeatability of the IC 22

3.4.3 Total Organic Compound Measurement 23

$\begin{array}{ll}\text { 3.4.3.1 TOC Method } & 23\end{array}$

\section{CHAPTER FOUR} RESULTS AND DISCUSSIONS WET AIR OXIDATION OF BENZENE

4.1 Experiments with Benzene in the Absence of Oxygen 25

4.2 Chemical Oxygen Demand Measurements 26

4.3 Repeatability of the Results $\quad 26$

4.4 Influence of $\mathrm{pH}$ on Benzene Degradation $\quad 28$

4.4.1 Effect of Temperature on Degradation of Benzene at pH 6

4.4.2 Effect of Oxygen Pressure on Benzene Degradation at $\mathrm{pH} 6 \quad 36$ 
4.4.3 Effect of Temperature on the Benzene Degradation at pH 5

4.4.4 Effect of the Oxygen Pressure on Benzene Degradation at pH 5

4.4.5 Effect of Temperature on Benzene Degradation at $\mathrm{pH} 4 \quad 40$

4.4.6 Effect of the Oxygen Pressure on the Benzene Degradation at pH $4 \quad 42$

4.4.7 The $\mathrm{pH}$ Fluctuation during the Experiments 45

4.4.8 Effect of Acidification Methods on the Degradation of Benzene 46

4.5 Effect of Initial Benzene Concentration on its Degradation 48

4.6 Kinetic Modeling 51

\section{CHAPTER FIVE RESULTS AND DISCUSSION REACTION INTERMEDIATES}

$\begin{array}{ll}5.1 \text { Total Organic Carbon Measurements } & 62\end{array}$

5.2 Effect of Temperature on the Production and Degradation of both Acetic Acid 69 and Formic Acid

5.3 Effect of Oxygen Pressure on the Production and Degradation of both Acetic 72 Acid and Formic Acid

5.4 Effect of pH on Acetic and Formic Acids

5.4.1 Effect of Acidification Methods on the Intermediates 81

5.5 Effect of Initial Benzene Concentration on Both Acetic and Formic Acids 83

5.6 Wet Air Oxidation of Both Acetic and Formic Acids $\quad 84$

5.7 Repeatability of the Results $\quad 86$ 


\section{CHAPTER SIX \\ RESULTS AND DISCUSSIONS \\ WET AIR OXIDATION OF BENZENE ENHANCED BY \\ PHENOL}

6.1 Wet Air Oxidation of Phenol in Absence of Benzene

6.2 Wet Air Oxidation of Benzene in Presence of Phenol

6.2.1 Effect of the Initial Phenol Concentration on Benzene Degradation

6.2.2 Effect of Temperature on the Benzene Degradation

6.2.3 Effect of Benzene on the Phenol Oxidation

6.3 Reaction Kinetics of Benzene Oxidation

6.4 Repeatability of the Experiments

6.5 Proposed Simplified Pathway for Oxidation of Benzene

104

\section{CHAPTER SEVEN \\ CONCLUSIONS AND RECOMMENDATIONS}

7.1 Conclusions

7.2 Recommendations for future work

7.3 Contributions to Knowledge 109

REFERENCES

\section{APPENDICES}

Appendix A: Calculation of Oxygen Pressure Needed

Appendix B: Oxygen Solubility in Water

Appendix C: Calculation of Theoretical Amount of Carbon Dioxide Generated 


\section{LIST OF FIGURES}

Figure 3.1 Schematic Diagram of the Experimental Setup

Page

Figure 3.2 Schematic Diagram for the Reactor, ID $=8.2 \mathrm{~cm}, \mathrm{OD}=11.2 \mathrm{~cm}$,

$\mathrm{L}=23.0 \mathrm{~cm}$

Figure 3.3 Upper View for the Cap

Figure 4.1 Repeatability of Data from Two Experiments at $220^{\circ} \mathrm{C}$,

$\mathrm{P}_{\mathrm{O} 2}=1.38 \mathrm{MPa}, \mathrm{pH}=4$.

Figure 4.2 Repeatability of Data from Two Experiments at $240^{\circ} \mathrm{C}$,

$\mathrm{P}_{\mathrm{O} 2}=1.38 \mathrm{MPa}, \mathrm{pH}=4$.

Figure 4.3 Repeatability of Data from Two Experiments at $260^{\circ} \mathrm{C}$, $\mathrm{P}_{\mathrm{O}_{2}}=1.38 \mathrm{MPa}, \mathrm{pH}=4$.

Figure 4.4 Effect of $\mathrm{pH}$ on Benzene Degradation at $190^{\circ} \mathrm{C}, \mathrm{P}_{\mathrm{O} 2}=1.38 \mathrm{MPa}$

Figure 4.5 Effect of $\mathrm{pH}$ on the Benzene Degradation at $220^{\circ} \mathrm{C}$,

$$
\mathrm{P}_{\mathrm{O} 2}=1.38 \mathrm{MPa}
$$

Figure 4.6 Effect of $\mathrm{pH}$ on the Benzene Degradation at $240^{\circ} \mathrm{C}$,

$\mathrm{P}_{\mathrm{O} 2}=1.38 \mathrm{MPa}$

Figure 4.7 Effect of $\mathrm{pH}$ on the Benzene Degradation at $260^{\circ} \mathrm{C}$,

$$
\mathrm{P}_{\mathrm{O} 2}=1.38 \mathrm{MPa}
$$

Figure 4.8 Degradation of Benzene at Different Temperatures,

$$
\mathrm{P}_{\mathrm{O} 2}=1.38 \mathrm{MPa}, \mathrm{pH}=6
$$

Figure 4.9 Repeatability of Data from Two Experiments at $240^{\circ} \mathrm{C}$,

$\mathrm{P}_{\mathrm{O} 2}=1.38 \mathrm{MPa}, \mathrm{pH}=6$

Figure 4.10 Degradation of Benzene at $200^{\circ} \mathrm{C}, \mathrm{P}_{\mathrm{O} 2}=1.38 \mathrm{MPa}, \mathrm{pH}=6$

Figure 4.11 Degradation of Benzene at $210^{\circ} \mathrm{C}, \mathrm{P}_{\mathrm{O} 2}=1.38 \mathrm{MPa}, \mathrm{pH}=6$.

Figure 4.12 Degradation of Benzene at Different Temperatures, $\mathrm{P}_{\mathrm{O} 2}=1.38 \mathrm{MPa}, \mathrm{pH}=6$

Figure 4.13 Degradation of Benzene at Different Oxygen Pressure, $\mathrm{T}=260^{\circ} \mathrm{C}$, 36 $\mathrm{pH}=6$ 
Figure 4.14 Effect of Oxygen Pressure on the Benzene Degradation at $260^{\circ} \mathrm{C}, \quad 37$ $\mathrm{pH}=6$

Figure 4.15 Effect of Temperature on the Benzene Degradation at $\mathrm{pH}$, $\mathrm{P}_{\mathrm{O} 2}=1.38 \mathrm{MPa}$

Figure 4.16 Effect of Oxygen Pressure on the Benzene Degradation at pH 5

Figure 4.17 Effect of Temperature on the Benzene Degradation at 1.03 MPa, $\mathrm{pH}=4$

Figure 4.18 Effect of Temperature on the Benzene Degradation at $1.38 \mathrm{MPa}$, $\mathrm{pH}=4$

Figure 4.19 Effect of Temperature on the Benzene Degradation at $1.72 \mathrm{MPa}$, $\mathrm{pH}=4$

Figure 4.20 Effect of Oxygen Pressure on the Benzene Degradation at $220^{\circ} \mathrm{C}$, $\mathrm{pH} 4$

Figure 4.21 Effect of Oxygen Pressure on the Benzene Degradation at $240^{\circ} \mathrm{C}$, $\mathrm{pH} 4$

Figure 4.22 Effect of Oxygen Pressure on the Benzene Degradation at $260^{\circ} \mathrm{C}$, $\mathrm{pH} 4$

Figure 4.23 Change of $\mathrm{pH}$ with Time during Experiment, $\mathrm{P}_{\mathrm{O} 2}=1.38 \mathrm{MPa}$, Initial Benzene Concentration $=5.63 \mathrm{mmol} / \mathrm{L}$

Figure 4.24 Degradation of Benzene with Sulfuric Acid at $220^{\circ} \mathrm{C}$, $\mathrm{P}_{\mathrm{O} 2}=1.38 \mathrm{MPa}, \mathrm{pH}=4$

Figure 4.25 Degradation of Benzene at $240^{\circ} \mathrm{C}, \mathrm{P}_{\mathrm{O} 2}=1.38 \mathrm{MPa}, \mathrm{pH}=4$

Figure 4.26 Degradation of Benzene at $260^{\circ} \mathrm{C}, \mathrm{P}_{\mathrm{O} 2}=2.07 \mathrm{MPa}, \mathrm{pH}=6$, Initial Benzene Concentration $=11.25 \mathrm{mmol} / \mathrm{L}$

Figure 4.27 Degradation of Benzene at $260^{\circ} \mathrm{C}, \mathrm{P}_{\mathrm{O} 2}=2.07 \mathrm{MPa}, \mathrm{pH}=6$,

Initial Benzene Concentration $=16.88 \mathrm{mmol} / \mathrm{L}$

Figure 4.28 Effect of Temperature on Benzene Degradation, $\mathrm{P}_{\mathrm{O} 2}=2.76 \mathrm{MPa}, \quad 50$ $\mathrm{pH}=4$, Initial Benzene Concentration of $11.25 \mathrm{mmol} / \mathrm{L}$

Figure 4.29 Change of $\mathrm{pH}$ with Time during Experiment, $\mathrm{T}=220^{\circ} \mathrm{C}, \mathrm{P}_{\mathrm{O} 2}=2.76$ $\mathrm{MPa}$, Initial Benzene Concentration $=11.25 \mathrm{mmol} / \mathrm{L}$

Figure 4.30 First Order Kinetic Model Fit of Benzene Degradation, $\mathrm{T}=220^{\circ} \mathrm{C}$, $\mathrm{P}_{\mathrm{O} 2}=0.69 \mathrm{MPa}, \mathrm{pH}=4$

Figure 4.31 First Order Kinetic Model Fit of Benzene Degradation, $\mathrm{T}=220^{\circ} \mathrm{C}$, 52 $\mathrm{P}_{\mathrm{O} 2}=0.86 \mathrm{MPa}, \mathrm{pH}=4$ 
Figure 4.32 First Order Kinetic Model Fit of Benzene Degradation, $\mathrm{T}=220^{\circ} \mathrm{C}, \quad 52$ $\mathrm{P}_{\mathrm{O} 2}=1.03 \mathrm{MPa}, \mathrm{pH}=4$

Figure 4.33 First Order Kinetic Model Fit of Benzene Degradation, $\mathrm{T}=220^{\circ} \mathrm{C}, \quad 53$ $\mathrm{P}_{\mathrm{O} 2}=1.38 \mathrm{MPa}, \mathrm{pH}=4$

Figure 4.34 First Order Kinetic Model Fit of Benzene Degradation, $\mathrm{T}=220^{\circ} \mathrm{C}, \quad 53$ $\mathrm{P}_{\mathrm{O} 2}=1.72 \mathrm{MPa}, \mathrm{pH}=4$

Figure 4.35 First Order Kinetic Model Fit of Benzene Degradation, $\mathrm{T}=240^{\circ} \mathrm{C}, \quad 54$ $\mathrm{P}_{\mathrm{O} 2}=1.03 \mathrm{MPa}, \mathrm{pH}=4$

Figure 4.36 First Order Kinetic Model Fit of Benzene Degradation, $\mathrm{T}=240^{\circ} \mathrm{C}, \quad 55$ $\mathrm{P}_{\mathrm{O} 2}=1.38 \mathrm{MPa}, \mathrm{pH}=4$

Figure 4.37 First Order Kinetic Model Fit of Benzene Degradation, $\mathrm{T}=240^{\circ} \mathrm{C}, \quad 55$ $\mathrm{P}_{\mathrm{O} 2}=1.72 \mathrm{MPa}, \mathrm{pH}=4$

Figure 4.38 First Order Kinetic Model Fit of Benzene Degradation, $\mathrm{T}=260^{\circ} \mathrm{C}, \quad 56$ $\mathrm{P}_{\mathrm{O} 2}=1.03 \mathrm{MPa}, \mathrm{pH}=4$

Figure 4.39 First Order Kinetic Model Fit of Benzene Degradation, $\mathrm{T}=260^{\circ} \mathrm{C}, \quad 56$ $\mathrm{P}_{\mathrm{O} 2}=1.38 \mathrm{MPa}, \mathrm{pH}=4$

Figure 4.40 First Order Kinetic Model Fit of Benzene Degradation, $\mathrm{T}=260^{\circ} \mathrm{C}, \quad 57$ $\mathrm{P}_{\mathrm{O} 2}=1.72 \mathrm{MPa}, \mathrm{pH}=4$

Figure 4.41 k' vs. $\mathrm{P}_{\mathrm{O} 2}, \mathrm{~T}=220^{\circ} \mathrm{C}, \mathrm{pH}=4$

Figure 4.42 k'vs. $\mathrm{P}_{\mathrm{O} 2}, \mathrm{~T}=240^{\circ} \mathrm{C}, \mathrm{pH}=4$

Figure 4.43 k'vs. $\mathrm{P}_{\mathrm{O} 2}, \mathrm{~T}=260^{\circ} \mathrm{C}, \mathrm{pH}=4$

Figure 4.44 Arrhenius Plot for Oxidation of Benzene, $\mathrm{pH}=4$

Figure 5.1 TOC Reduction with Time, $\mathrm{P}_{\mathrm{O} 2}=1.38 \mathrm{MPa}, \mathrm{pH}=6$

Figure 5.2 Detailed Change in Carbon Concentration with Time, T $=220^{\circ} \mathrm{C}, \quad 64$ $\mathrm{pH}=6, \mathrm{P}_{\mathrm{O} 2}=1.38 \mathrm{MPa}$

Figure 5.3 Detailed Change in Carbon Concentration with Time, $\mathrm{T}=240^{\circ} \mathrm{C}, \quad 64$ $\mathrm{pH}=6, \mathrm{P}_{\mathrm{O} 2}=1.38 \mathrm{MPa}$

Figure 5.4 Detailed Change in Carbon Concentration with Time, $\mathrm{T}=260^{\circ} \mathrm{C}, \quad 65$ $\mathrm{pH}=6, \mathrm{P}_{\mathrm{O} 2}=1.38 \mathrm{MPa}$

Figure 5.5 Carbon Balance, $\mathrm{T}=220^{\circ} \mathrm{C}, \mathrm{pH}=6, \mathrm{P}_{\mathrm{O} 2}=1.38 \mathrm{MPa}$ 
Figure 5.6 Carbon Balance, $\mathrm{T}=240^{\circ} \mathrm{C}, \mathrm{pH}=6, \mathrm{P}_{\mathrm{O} 2}=1.38 \mathrm{MPa}$

Figure 5.7 Carbon Balance, $\mathrm{T}=260^{\circ} \mathrm{C}, \mathrm{pH}=6, \mathrm{P}_{\mathrm{O} 2}=1.38 \mathrm{MPa}$

Figure 5.8 Repeatability of Carbon Balance, $\mathrm{T}=220^{\circ} \mathrm{C}, \mathrm{pH}=6, \mathrm{P}_{\mathrm{O} 2}=1.38 \mathrm{MPa} \quad 67$

Figure 5.9 Repeatability of Carbon Balance, $\mathrm{T}=240^{\circ} \mathrm{C}, \mathrm{pH}=6, \mathrm{P}_{\mathrm{O} 2}=1.38 \mathrm{MPa} \quad 67$

Figure 5.10 Repeatability of Carbon Balance, $\mathrm{T}=260^{\circ} \mathrm{C}, \mathrm{pH}=6, \mathrm{P}_{\mathrm{O} 2}=1.38 \mathrm{MPa} \quad 68$

Figure 5.11 Effect of Temperature on Acetic Acid, $\mathrm{P}_{\mathrm{O} 2}=1.38 \mathrm{MPa}, \mathrm{pH}=6$

Figure 5.12 Effect of Temperature on Acetic Acid, $\mathrm{P}_{\mathrm{O} 2}=1.38 \mathrm{MPa}, \mathrm{pH}=4$

Figure 5.13 Effect of Temperature on Formic Acid, $\mathrm{P}_{\mathrm{O} 2}=1.38 \mathrm{MPa}, \mathrm{pH}=6$

Figure 5.14 Effect of Temperature on Formic Acid, $\mathrm{P}_{\mathrm{O} 2}=1.38 \mathrm{MPa}, \mathrm{pH}=4$

Figure 5.15 Effect of Pressure on Acetic Acid $\mathrm{T}=260^{\circ} \mathrm{C}, \mathrm{pH}=6$

Figure 5.16 Effect of Pressure on Formic Acid, $\mathrm{T}=260^{\circ} \mathrm{C}, \mathrm{pH}=6$

Figure 5.17 Effect of Pressure on Acetic Acid, $\mathrm{T}=220^{\circ} \mathrm{C}, \mathrm{pH}=4$

Figure 5.18 Effect of Pressure on Acetic Acid, $\mathrm{T}=240^{\circ} \mathrm{C}, \mathrm{pH}=4$

Figure 5.19 Effect of Pressure on Acetic Acid, $\mathrm{T}=260^{\circ} \mathrm{C}, \mathrm{pH}=4$

Figure 5.20 Effect of Pressure on Formic Acid, $\mathrm{T}=220^{\circ} \mathrm{C}, \mathrm{pH}=4$

Figure 5.21 Effect of Pressure on Formic Acid, $\mathrm{T}=240^{\circ} \mathrm{C}, \mathrm{pH}=4$

Figure 5.22 Effect of Pressure on Formic Acid, $\mathrm{T}=260^{\circ} \mathrm{C}, \mathrm{pH}=4$

Figure 5.23 Effect of $\mathrm{pH}$ on Acetic Acid, $\mathrm{T}=220^{\circ} \mathrm{C}, \mathrm{pH}=4, \mathrm{P}_{\mathrm{O} 2}=1.38 \mathrm{MPa}$ 
Figure 5.24 Effect of $\mathrm{pH}$ on Formic Acid, $\mathrm{T}=220^{\circ} \mathrm{C}, \mathrm{pH}=4, \mathrm{P}_{\mathrm{O} 2}=1.38 \mathrm{MPa}$

Figure 5.25 Effect of $\mathrm{pH}$ on Acetic Acid, $\mathrm{T}=240^{\circ} \mathrm{C}, \mathrm{pH}=4, \mathrm{P}_{\mathrm{O} 2}=1.38 \mathrm{MPa}$

Figure 5.26 Effect of $\mathrm{pH}$ on Formic Acid, $\mathrm{T}=240^{\circ} \mathrm{C}, \mathrm{pH}=4, \mathrm{P}_{\mathrm{O} 2}=1.38 \mathrm{MPa}$

Figure 5.27 Effect of $\mathrm{pH}$ on Acetic Acid, $\mathrm{T}=260^{\circ} \mathrm{C}, \mathrm{pH}=4, \mathrm{P}_{\mathrm{O} 2}=1.38 \mathrm{MPa}$

Figure 5.28 Effect of $\mathrm{pH}$ on Formic Acid, $\mathrm{T}=260^{\circ} \mathrm{C}, \mathrm{pH}=4, \mathrm{P}_{\mathrm{O} 2}=1.38 \mathrm{MPa}$

Figure 5.29 Effect of Acidification Methods on Acetic Acid, $\mathrm{T}=220^{\circ} \mathrm{C}$, $\mathrm{P}_{\mathrm{O} 2}=1.38 \mathrm{MPa}, \mathrm{pH}=4$

Figure 5.30 Effect of Acidification Methods on Formic Acid, $\mathrm{T}=220^{\circ} \mathrm{C}$, $\mathrm{P}_{\mathrm{O} 2}=1.38 \mathrm{MPa}, \mathrm{pH}=4$

Figure 5.31 Effect of Temperature on Acetic Acid, $\mathrm{P}_{\mathrm{O} 2}=2.76 \mathrm{MPa}, \mathrm{pH}=4$, Initial Benzene Concentration $=11.3 \mathrm{mmol} / \mathrm{L}$

Figure 5.32 Effect of Temperature on Formic Acid, $\mathrm{P}_{\mathrm{O} 2}=2.76 \mathrm{MPa}, \mathrm{pH}=4$

Figure 5.33 Degradation of Acetic Acid, $\mathrm{T}=260^{\circ} \mathrm{C}, \mathrm{P}_{\mathrm{O} 2}=2.07 \mathrm{MPa}$

Figure 5.34 Acetic acid profile for replicates, $\mathrm{T}=220^{\circ} \mathrm{C}, \mathrm{P}_{\mathrm{O} 2}, 1.38 \mathrm{MPa}, \mathrm{pH}=4$

Figure 5.35 Acetic acid profile for replicates, $\mathrm{T}=240^{\circ} \mathrm{C}, \mathrm{P}_{\mathrm{O} 2}, 1.38 \mathrm{MPa}, \mathrm{pH}=4$

Figure 5.36 Acetic acid profile for replicates, $\mathrm{T}=260^{\circ} \mathrm{C}, \mathrm{P}_{\mathrm{O} 2}, 1.72 \mathrm{MPa}, \mathrm{pH}=4$

Figure 5.37 Formic acid profile for replicates, $\mathrm{T}=220^{\circ} \mathrm{C}, \mathrm{P}_{\mathrm{O} 2}, 1.38 \mathrm{MPa}, \mathrm{pH}=4$

Figure 5.38 Formic acid profile for replicates, $\mathrm{T}=240^{\circ} \mathrm{C}, \mathrm{P}_{\mathrm{O} 2}, 1.38 \mathrm{MPa}, \mathrm{pH}=4$

Figure 5.39 Formic acid profile for replicates, $\mathrm{T}=260^{\circ} \mathrm{C}, \mathrm{P}_{\mathrm{O} 2}, 1.72 \mathrm{MPa}, \mathrm{pH}=4$

Figure 6.1 Acetic Acid and Formic Acid Profile, $\mathrm{T}=220^{\circ} \mathrm{C}, \mathrm{P}_{\mathrm{O} 2}=2.07 \mathrm{MPa}$, $\mathrm{pH}=4$. Initial Phenol Concentration $=500 \mathrm{mg} / \mathrm{L}$

Figure 6.2 Acetic Acid and Formic Acid Profile, $\mathrm{T}=220^{\circ} \mathrm{C}, \mathrm{P}_{\mathrm{O} 2}=1.38 \mathrm{MPa}$, $\mathrm{pH}=6$. Initial Phenol Concentration $=500 \mathrm{mg} / \mathrm{L}$ 
Figure 6.3 Acetic Acid and Formic Acid Profile, $\mathrm{T}=220^{\circ} \mathrm{C}, \mathrm{P}_{\mathrm{O} 2}=0.51 \mathrm{MPa}, \quad 93$ $\mathrm{pH}=4$. Initial Phenol Concentration $=200 \mathrm{mg} / \mathrm{L}$

Figure 6.4 Degradation of Benzene at $220^{\circ} \mathrm{C}, \mathrm{P}_{\mathrm{O} 2}=1.72 \mathrm{MPa}$

Figure 6.5 Degradation of Phenol at $220^{\circ} \mathrm{C}, \mathrm{P}_{\mathrm{O} 2}=1.72 \mathrm{MPa}$

Figure 6.6 Degradation of Benzene at Different Initial Phenol 96 Concentrations, $\mathrm{T}=220^{\circ} \mathrm{C}, 100 \%$ Excess $\mathrm{O}_{2}$, Initial $\mathrm{pH}=6$

Figure 6.7 Degradation of Benzene at Different Initial Phenol 97 Concentrations, $\mathrm{T}=200^{\circ} \mathrm{C}, 100 \%$ Excess $\mathrm{O}_{2}$, Initial $\mathrm{pH}=6$

Figure 6.8 Degradation of Benzene at Different Temperatures, 100\% Excess 98 $\mathrm{O}_{2}$, Initial Phenol Concentration $=0.27 \mathrm{mmol} / \mathrm{L}$, Initial $\mathrm{pH}=6$

Figure 6.9 Degradation of Benzene at Different Temperatures, $100 \%$ Excess $\mathrm{O}_{2}$, Initial Phenol Concentration $=0.53 \mathrm{mmol} / \mathrm{L}$, Initial $\mathrm{pH}=6$

Figure 6.10 Normalized concentration of Phenol with Time, 100\% Excess $\mathrm{O}_{2}$, Initial $\mathrm{pH}=6$, Initial Phenol Concentration $=0.53 \mathrm{mmol} / \mathrm{L}$

100

Figure 6.11 Normalized concentration of Phenol with Time, 100\% Excess $\mathrm{O}_{2}, \quad 101$ Initial $\mathrm{pH}=6$, Initial Phenol Concentration $=0.27 \mathrm{mmol} / \mathrm{L}$

Figure 6.12 Pseudo First Order Kinetic Plot for Benzene

Figure 6.13 Arrhenius Plot for Pseudo First Order Rate Constant Calculated 102 from Benzene Removal Data

Figure 6.14 Repeatability of Benzene Result at $220^{\circ} \mathrm{C}, 100 \%$ Excess $\mathrm{O} 2,103$ Initial $\mathrm{pH}=6$, Initial Phenol Concentration $=0.27 \mathrm{mmol} / \mathrm{L}$

Figure 6.15 Repeatability of Phenol Result at $220^{\circ} \mathrm{C}, 100 \%$ Excess O2, Initial $\mathrm{pH}=6$, Initial Phenol Concentration $=0.27 \mathrm{mmol} / \mathrm{L}$

Figure 6.16 Simplified Pathway for Oxidation of Benzene 


\section{LIST OF TABLES}

Table 4.1 Solubility of Oxygen in Water at Different Temperatures

Table 4.2 k' Values at Different $\mathrm{P}_{\mathrm{O} 2}$ for the Fast Step, $\mathrm{T}=220^{\circ} \mathrm{C}$

Table 4.3 k' Values at Different $\mathrm{P}_{\mathrm{O} 2}$ for the Fast Step, $\mathrm{T}=240^{\circ} \mathrm{C}$

Table 4.4 k' Values at Different $\mathrm{P}_{\mathrm{O} 2}$ for the Fast Step, $\mathrm{T}=260^{\circ} \mathrm{C}$

Table 4.5 Rate Constant Value at Different Temperatures

Table 5.1 Carbon Dioxide Measurement, $\mathrm{pH}=6, \mathrm{P}_{\mathrm{O} 2}=1.38 \mathrm{MPa}$

Table 5.2 Effect of Temperature on Formic Acid

Table 5.3 Concentration of Formic Acid at Different Temperatures

Table 6.1 Degradation of Phenol at $220^{\circ} \mathrm{C}$

92 


\section{CHAPTER ONE}

\section{INTRODUCTION}

Processing of organic compounds produces a large amount of wastewater, which consists of toxic (hazardous) materials that cannot be discharged to the environment without treatment. As restrictive environmental constraints increase, new technologies are needed to treat those toxic materials before discharging them to the environment. Wet Air Oxidation (WAO) is one of these methods. It is defined as the oxidation of soluble or suspended oxidizable components in an aqueous environment using either pure oxygen or air as an oxidizing agent at elevated temperature and pressure. It is a very attractive method for wastewater treatment, especially when the effluent is too dilute for incineration, and either too toxic or concentrated for biological treatment. Typically, WAO takes place at a temperature range of $125-320^{\circ} \mathrm{C}$ and at a pressure range of $0.5-30$ $\mathrm{MPa}$. The residence time ranges between 15 and 120 minutes. The need of the high pressure is to maintain the liquid phase at the elevated temperatures. The final products in this method are water, carbon dioxide and low molecular weight organics. The overall reaction for organic materials can be expressed as:

$$
\text { Organics }+\mathrm{O}_{2} \longrightarrow \mathrm{CO}_{2}+\mathrm{H}_{2} \mathrm{O}+\mathrm{LMWO}
$$

WAO has several advantages and disadvantages. Some of the advantages are as follows: It can treat more than one chemical compound at the same time; it is environmentally friendly since the destruction of the wastes is in the liquid phase and in comparison to incineration, no nitrogen oxides are generated. Finally, it does not need a dewatering step as a pretreatment. On the other hand, there are some disadvantages associated with the WAO. It is limited to wastes that contain oxidizable organic and 
inorganic compounds. Also, it is costly since it involves both high temperatures and pressures.

\subsection{Petrochemical Wastewater Effluent}

The waste effluents from the petrochemical industries contain a large amount of various organic compounds which cannot be discharged to the environment without treatment. Among the many available methods, activated sludge treatment is the most widely used because of its simplicity and low cost [47]. However, it can not be used for highly concentrated wastes due to a low biodegradability and inhibitory effects of the organic compounds [50]. For the wastewaters containing phenol and phenolic compounds which are very common in petrochemical industries, solvent extraction is an economical method if the concentration of these compounds is high (i.e. over $1 \%$ ) $[12,22]$. If the concentration is low, biological treatment is the appropriate method. Finally, incineration can be an economically attractive alternative although it is limited only for concentrated wastes and it contributes to air pollution.

\subsubsection{Benzene}

Benzene $\left(\mathrm{C}_{6} \mathrm{H}_{6}\right)$ is an aromatic hydrocarbon with a molecular weight of $78.1 \mathrm{~g} / \mathrm{mol}$. It is a clear, colorless liquid that is volatile and highly flammable. Its water solubility is about $1750 \mathrm{mg} / \mathrm{L}$ at $25^{\circ} \mathrm{C} \mathrm{[5].} \mathrm{It} \mathrm{is} \mathrm{known} \mathrm{to} \mathrm{be} \mathrm{a} \mathrm{carcinogenic} \mathrm{compound} \mathrm{[23]} \mathrm{and} \mathrm{is}$ usually found in the wastewater effluents of the petrochemical industries. A strong association between leukemia and modest benzene exposure greater than $16 \mathrm{mg} / \mathrm{L}$ per year has been demonstrated [21]. Effluents that contain benzene can not be discharged to 
the environment without further treatment in order to remove benzene, which is very harmful to the environment even at very low concentrations. While the exposure limit for

drinking water to benzene is set to be $5 \mu \mathrm{g} / \mathrm{L}$ in the United States, it is set to be $25 \mu \mathrm{g} / \mathrm{L}$ in Canada [35]. Benzene is known to be a very refractory compound; that is very difficult to oxidize. While the aerobic benzene biodegradation has been observed since the 1950 's, the anaerobic benzene degradation was only discovered on 1980 by Ward et al. [68] and since then much attention was given to it, especially when an extensive anaerobic zone was developed by soils and sediments contaminated with benzene $[1,9,43]$. Coates et al. [10] were the first group to report the isolation of two Dechloromonas strains that can completely degrade the benzene anaerobically under nitrate reducing conditions. There has been no single publication available that deals with the wet air oxidation of benzene.

\subsection{Objectives}

The objectives of this study were as follows:

- To study the effect of initial $\mathrm{pH}$ on the wet air oxidation of benzene at different temperatures and pressures, hence to find the optimum conditions at which the benzene will be degraded.

- To determine the main intermediates that resulted from benzene degradation.

- To study the kinetics of benzene degradation.

- To study the degradation of benzene in the presence of phenol which is known to be a common component in many of the wastewater streams.

- To study the kinetics of benzene degradation enhanced by phenol. 


\subsection{Thesis Structure}

This thesis casts light on the wet air oxidation of benzene. The literature about the wet air oxidation of some of the organic components that exist in the wastewater from petrochemical industries will be reviewed in chapter 2 .

Chapter 3 summarizes the experimental methods that were utilized in this study. A detailed description of the experimental setup, materials, procedures and analytical methods used for analysis is presented. In Chapter 4 , the results for benzene degradation are presented. The influence of $\mathrm{pH}$ on benzene degradation at different temperatures and pressures is discussed. The kinetic modeling for benzene removal is presented.

Chapter 5 deals with the results that have been obtained regarding the reaction intermediates. Total Organic Carbon (TOC) measurements are presented. Effect of temperature, pressure and $\mathrm{pH}$ on both, production and degradation of intermediates, is discussed. WAO for acetic acid and formic acid is presented.

The WAO of benzene enhanced by phenol is presented in Chapter 6 . The effect of the initial phenol concentration on benzene degradation is shown. The effect of temperature on the benzene degradation is discussed. The effect of benzene on the oxidation of phenol is presented. Reaction kinetics of benzene oxidation enhanced by phenol is presented. The simplified pathway for benzene oxidation is presented.

The general conclusions, recommendations for future work and contributions to knowledge are presented in Chapter 7. 


\section{CHAPTER TWO}

\section{LITERATURE REVIEW}

During the last decades, WAO has been the subject of intensive studies in both chemical and environmental engineering literature. The most important applications are in municipal sewage sludge treatment, industrial wastewater treatment, carbon regeneration, and pulping spent liquors. Many of the studies that have been reported in the literature dealt with both phenol and carboxylic acids. [6,48]

\subsection{WAO of Organic Compounds}

Numerous studies have been done on the WAO of organic compounds. Phenol in particular was a subject of considerable interest since it is found in the wastewater of many industries such as the petrochemicals, plastics and pulp and paper industries. Also, numerous studies have been done on the wet air oxidation of the carboxylic acids since they are the main intermediates during the wet air oxidation of the other organic compounds, and they are usually difficult to oxidize.

\subsubsection{WAO of Phenol}

Phenol is considered to be one of the most common and important pollutants that can be found in the effluent streams of most chemical plants. It is highly toxic even at low concentrations and therefore wastewaters that contain phenol should be treated before they can be discharged to environment. WAO is an effective method for the treatment of effluents containing phenol. Some researchers studied the degradation of phenol while 
the others were more concerned about the environment and therefore studied the COD reduction instead. Joglekar et al. [33] studied the WAO of phenol in the temperature range of $150-180^{\circ} \mathrm{C}$ and oxygen partial pressure from 0.3 to $1.5 \mathrm{MPa}$, and reported that more than $90 \%$ COD reduction was achieved, while Lin and Chuang [39] reached $100 \%$ COD reduction at an oxygen partial pressure of $10.3 \mathrm{MPa}$ and $300^{\circ} \mathrm{C}$. Kolaczkowski et al. [36] showed that more than $95 \%$ phenol degradation was achieved in less than 30 minutes at $200^{\circ} \mathrm{C}$ and total pressure of 3.0 MPa. Portela Miguelez [52] studied the WAO of phenol and achieved around $100 \%$ degradation at $300^{\circ} \mathrm{C}$ and a total pressure of 10 MPa in less than 10 minutes. Imamura [24] studied the degradation of phenol at $220^{\circ} \mathrm{C}$ and oxygen partial pressure of 3MPa. The COD and TOC reduction achieved in two hours were $93 \%$ and $88 \%$, respectively. Complete phenol degradation was achieved in 10 minutes at $220^{\circ} \mathrm{C}$ and $10.15 \mathrm{MPa}$ in the study that has been done by Vicente et al. [66]. Vaidya and Mahajani [64] reported more than $90 \%$ COD reduction in 30 minutes at $230^{\circ} \mathrm{C}$ and oxygen partial pressure of $0.69 \mathrm{MPa}$ in their study of WAO of phenol.

In summary, the WAO of phenol was studied at a temperature range between 150 to $300^{\circ} \mathrm{C}$ and oxygen partial pressure range between 0.3 to $10.3 \mathrm{MPa}$. It was found that considerable phenol degradation can be achieved even at mild temperatures.

\subsubsection{WAO of Formic Acid and Acetic Acid}

Low molecular weight carboxylic acids, especially acetic acid, are resistant to oxidation $[26,29,30,31]$. They are either originally found in the waste or generated as intermediates during the WAO of various waste streams, and they accumulate at the latter stages of WAO $[3,4,17,18,19,34,72]$, hence becoming a major limitation of the process. 
Many studies that deal with the oxidation of the mono-and dicarboxylic acids were carried out with the main aim being the determination of the kinetic parameters together with TOC and COD removal. Most of the studies were done using a temperature in the range of $230-290^{\circ} \mathrm{C}$, and a pressure of $0.35-12.8 \mathrm{MPa}$ [48]. Chowdary and Copa [8] achieved $98.3 \%$ reduction of formic acid at $300^{\circ} \mathrm{C}$ in 60 minutes. Shendi and Mahajani [59] studied the WAO of formic acid in the temperature range $150-240^{\circ} \mathrm{C}$ and partial oxygen pressure of $0.69 \mathrm{MPa}$. Their results showed $12.92 \%$ and $95 \%$ COD reduction at $150^{\circ} \mathrm{C}$ and $240^{\circ} \mathrm{C}$, respectively. Shendi and Levec [58] studied the wet oxidation kinetic of some refractory low molecular mass carboxylic acids. While only $24 \%$ formic acid degradation was achieved in 2 hours at $240^{\circ} \mathrm{C}$ and $0.8 \mathrm{MPa}$ of partial oxygen pressure, around $90 \%$ degradation was achieved at $270^{\circ} \mathrm{C}$.

For the acetic acid, 9\% degradation was achieved at $300^{\circ} \mathrm{C}$ and partial oxygen pressure of $6 \mathrm{MPa}$ while $20 \%$ degradation was achieved at $320^{\circ} \mathrm{C}$ and partial oxygen pressure of $3 \mathrm{MPa}$. The methyl group which is an electron donor to the carbon having $=\mathrm{O}$ and $-\mathrm{OH}$ group is the main cause for the high stability of acetic acid [58]. While Imamura et al. [25] showed only $24.9 \%$ TOC reduction at $150^{\circ} \mathrm{C}$ and an oxygen pressure of $1 \mathrm{MPa}$ in 1 hour, $42.0 \%$ TOC removal was achieved for acetic acid when the temperature was increased to $247^{\circ} \mathrm{C}$ [28]. The wet air oxidation of acetic acid was studied by Merchant [46] and it was found that only $7 \% \mathrm{COD}$ reduction was achieved at $275^{\circ} \mathrm{C}$ in 5 hours. The WAO of both formic acid and acetic acid were studied by Imamura [24] at $220^{\circ} \mathrm{C}$ and partial oxygen pressure of $3 \mathrm{MPa}$ in 2 hours. $99 \%$ TOC reduction and $100 \%$ COD reduction was achieved for formic acid while only $4 \%$ TOC reduction and $10 \%$ COD reduction were achieved for acetic acid. 
In summary, the wet air oxidation of acetic and formic acids was studied at a temperature range between 150 to $320^{\circ} \mathrm{C}$ and an oxygen pressure range between 0.35 to 12.8 MPa. It can be concluded that while the formic acid was easily degraded, the acetic acid was resistant to oxidation and in most cases stayed as a final product.

\subsection{Free Radical Mechanism}

The destruction of the organic compounds in the WAO method follows a free-radical mechanism [38]. The free radical mechanism has been proposed by many researchers $[13,16,32,39,45,51,54,67]$; however, only a few of them supported that by direct experimental evidence [6]. In the absence of initiators, free radicals are formed by the reaction of oxygen with the weakest $\mathrm{C}-\mathrm{H}$ bonds of the oxidized organic compound as follows:

$$
\begin{aligned}
& \mathrm{RH}+\mathrm{O}_{2} \rightarrow \mathrm{R}^{\bullet}+\mathrm{HO}_{2}^{\bullet} \\
& \mathrm{RH}+\mathrm{HO}_{2}^{\bullet} \rightarrow \mathrm{R}^{\bullet}+\mathrm{H}_{2} \mathrm{O}_{2}
\end{aligned}
$$

where $\mathrm{R}$ denotes the organic functional group. In the case of phenol, the reaction of oxygen with the $\mathrm{O}-\mathrm{H}$ bond may also form free radicals. The hydrogen peroxide decomposes to generate hydroxyl radicals. The oxidation of the organic compound by hydroxyl radicals follows a hydrogen abstraction mechanism as shown in equation 2-4.

$$
\begin{aligned}
& \mathrm{H}_{2} \mathrm{O}_{2} \rightarrow 2 \mathrm{HO}^{\bullet} \\
& \mathrm{RH}+\mathrm{HO}^{\bullet} \rightarrow \mathrm{R}^{\bullet}+\mathrm{H}_{2} \mathrm{O}
\end{aligned}
$$


The organic radical $R^{\bullet}$ then reacts with oxygen to form an organic peroxy radical $\left(R O O^{\circ}\right)$ which further abstracts hydrogen atom from the organic compound to produce an organic hydroperoxide $(\mathrm{ROOH})$ and another organic radical.

$\mathrm{R}^{\bullet}+\mathrm{O}_{2} \rightarrow \mathrm{ROO}^{\bullet}$

$R O O^{\bullet}+R H \rightarrow R O O H+R^{\bullet}$

The organic hydroperoxides, which are formed are relatively unstable and decompose to intermediates with lower carbon numbers. These reactions continue rapidly until the formation of the acetic and formic acid which will eventually be converted to carbon dioxide and water [38].

Robert et al. [56] is the only one who provided a direct experimental evidence of free radical intermediates under typical WO conditions when they studied the wet oxidation of cellulose. In their study, the $\left(\mathrm{HO}^{\circ}\right)$ hydroxyl radical that is a free radical intermediate proposed by many researchers was identified. On the other hand, there are some indirect methods to determine the free radical reactions. The co-oxidation is one of these methods. In this method the free radicals that are produced from an easily oxidizable compound are used to initiate the oxidation of more refractory compounds [6]. In his study of WO of sodium malonate in highly alkaline solution, Tardio [61] used this method to determine the presence of free radical intermediates. Imamura also reported this method in his study of the wet oxidation of Polyethylene glycols (PEG's).

Some researchers used a free radical initiator to enhance the oxidation. Rivas et al. [55] showed that the addition of hydrogen peroxide not only significantly enhanced the wet air oxidation of phenol but also eliminated the induction time period experienced 
during the conventional wet air oxidation at mild conditions. Rivas et al. [53] in their study about the wet air oxidation of landfill leachates tried both hydrogen peroxide and Oxone as free radical promoters. They showed that the additions of those promoters enhanced the COD reduction. Using free radical reaction inhibitors is another indirect method to determine free radical reactions. Vaidya and Mahajani [64] showed that by using t-butanol, which is known to be a free radical inhibitor, the degradation rate of phenol was decreased.

\subsubsection{Induction Period}

The induction period, which is typical of free radical reactions, is defined as the time needed for the free radicals to be generated in a sufficient concentration [69]. Willms et $a l$. [70] studied the WAO of both m-xylene and phenol at a temperature range between 27 to $227^{\circ} \mathrm{C}$ and a total pressure range between $7-14 \mathrm{MPa}$. They found that the oxidation reactions of both compounds are characterized by an induction period during which no reaction was noticed. They reported that the induction time was inversely proportional to the dissolved oxygen concentration. The induction period was also observed for phenol by Joglekar et al. [33]. Their study was conducted in temperature range between 150$180^{\circ} \mathrm{C}$ and oxygen partial pressures range between 0.3 to $1.5 \mathrm{MPa}$ and initial phenol concentration was $200 \mathrm{mg} / \mathrm{L}$. Portela Miguelez et al. [52] studied the wet air oxidation of phenol in a batch reactor at temperatures between $150-300^{\circ} \mathrm{C}$ and pressures from 10 to 20 $\mathrm{MPa}$, while the initial oxygen concentration was always above $800 \%$ excess. They found that the induction time was over 1 hour at $150^{\circ} \mathrm{C}$ and it decreased with the increase of the temperature until it almost disappeared at $300^{\circ} \mathrm{C}$. Thomsen [62] in his study about the 
degradation of quinoline by wet oxidation found that the temperature has a dramatic effect on the induction period. While the induction time was 45 minutes at $220^{\circ} \mathrm{C}$, it was less than 10 minutes when the temperature was increased to $240^{\circ} \mathrm{C}$. These studies showed the significant effect of the temperature on the induction period.

\subsection{Effect of the Initial pH on the WAO}

The initial $\mathrm{pH}$ has a significant effect on both the WAO reaction rate and pathway [36]. However, the operating $\mathrm{pH}$, which is different than the initial $\mathrm{pH}$, has a complex effect on reaction rate $[36,64]$. Only a few studies have been reported about the effect of $\mathrm{pH}$ on the wet oxidation of organic compounds [64]. The $\mathrm{pH}$ of the solution has an effect on the type of free radical reactions that occur during WAO and the stability of the free radical intermediates formed. The oxidizing strength of free radical intermediates decreases at alkaline conditions in most cases since in alkaline solution, carbonate, bicarbonate and hydroxide can scavenge hydroxyl radicals [6]

$$
\begin{aligned}
& \mathrm{HO}^{\bullet}+\mathrm{CO}_{3}^{2-} \rightarrow{ }^{-} \mathrm{OH}+{ }^{\bullet} \mathrm{CO}_{3}^{-} \\
& \mathrm{HO}^{\bullet}+\mathrm{HCO}_{3}^{2-} \rightarrow \mathrm{H}_{2} \mathrm{O}^{\bullet} \mathrm{CO}_{3}^{-} \\
& \mathrm{HO}^{\bullet}+{ }^{-} \mathrm{OH} \rightarrow \mathrm{H}_{2} \mathrm{O}+\mathrm{O}^{\bullet-}
\end{aligned}
$$

Kolaczkowski et al. [36] studied the WAO of phenol at $200^{\circ} \mathrm{C}$ and pressure of 3.0 $\mathrm{MPa}$ with different initial $\mathrm{pH}$ and found that the initial $\mathrm{pH}$ has a significant effect on the WAO reaction rate. For $\mathrm{pH}$ less than or equal to 2 and between 7 and 10 , no reaction took place. However, when no acid or base was added, i.e. when $\mathrm{pH}$ was approximately 4, significant phenol decomposition was achieved. Also, when the $\mathrm{pH}$ was adjusted to be above the $\mathrm{pK}_{\mathrm{a}}$ of phenol, rapid oxidation was achieved with no induction period. This can 
be attributed to the effect $\mathrm{pH}$ has on the chemical structure of the phenol, i.e. the phenolate ion is highly reactive [6,36]. The change of $\mathrm{pH}$ during the oxidation period has a noticeable effect on both the phenol decomposition and COD removal [39]. When buffer was added in order to stabilize the $\mathrm{pH}$, the COD reduction decreased dramatically.

The WAO of carboxylic acids is also affected by the $\mathrm{pH}$ of the solution. While $90 \%$ TOC reduction was achieved for oxalic acid at a $\mathrm{pH}$ of 2.5 and $160^{\circ} \mathrm{C}$ within 20 minutes [27], less than $2 \%$ TOC conversion was achieved at $\mathrm{pH}$ greater than 14 within $2 \mathrm{~h}$ at $165^{\circ} \mathrm{C}[60,61]$. In their study of the catalytic WAO of formic acid Imamura et al. [25] showed that the reactivity depends remarkably on $\mathrm{pH}$. They achieved total TOC removal at $150^{\circ} \mathrm{C}$, oxygen partial pressure of $1.0 \mathrm{MPa}$ and at $\mathrm{pH}$ of 1.9 , while only $7 \%$ degradation was achieved at $\mathrm{pH}$ of 5.6, which suggests that the reactivity of the formic acid is more than the formate ion since the $\mathrm{pK}_{\mathrm{a}}$ of formic acid is 3.75 . They showed also that the oxidation of acetic acid was also affected by the $\mathrm{pH}$. While $44.5 \%$ TOC degradation was achieved at $200^{\circ} \mathrm{C}$ in 1 hour at $\mathrm{pH}$ of 2.7 in the oxidation catalyzed by $\mathrm{Ru} / \mathrm{Ce}$, only $19.4 \%$ was achieved at $\mathrm{pH}$ of 6.9 . Those results show the strong influence of the $\mathrm{pH}$ on the WAO process for different organic compounds.

\subsection{Wet Air Oxidation Enhancements}

In the last section, it was shown how the $\mathrm{pH}$ can affect the WAO of many organic compounds. In addition, there are numerous other methods that have been reported in order to increase the effectiveness of the WAO. One of these is the catalytic wet air oxidation in which either homogenous or heterogeneous catalysts were used to enhance the degradation $[11,25,40,44]$. The wet oxidation method was also enhanced by using 
ozone [3] or hydrogen peroxide $[14,15,42]$ as an oxidizing agent. Supercritical oxidation [37] was also tried in order to improve the oxidation of some compounds.

The Co-oxidation method, which was discussed in section 2.3, was reported to be one of the promising methods that can be used to enhance the WAO. In 1987, Willims et al. [71] showed that the addition of phenol to a solution containing $\mathrm{m}$-xylene enhanced the oxidation rate of $\mathrm{m}$-xylene. Ingale et al. [32] reported that the degradation rate of acetic acid is faster when it is present with other compounds than when it is alone. Shendi and Levec [58] showed that at the same operating conditions, the conversion of formic acid was about $11 \%$ higher when an equal amount of acetic acid was added to the solution. Birchmeier et al. [7] reported that the oxidation of recalcitrant low molecular weight acids was enhanced by the addition of either phenol or cellobiose to the solution. The degradation of thiocyanate was significantly enhanced when simultaneously oxidized together with phenol, as shown by Vicente and Diaz [65]. Recently, Fu et al. [20] studied the wet air oxidation of nitrobenzene and they reported that the presence of phenol in the reaction media enhanced the removal of nitrobenzene.

As suggested in the literature, the first intermediate formed during the wet air oxidation of phenol is hydroquinone, which is unstable and breaks rapidly in the presence of excess oxygen forming other low molecular weight products and carbon dioxide [51]. It also forms hydrogen peroxide. The hydrogen peroxide then produces hydroxyl and perhydroxyl radicals [36]. Hydroxyl radicals have the second highest oxidation potential after fluorine, which makes them very reactive oxidants [64]. Because of the presence of these radicals the rate of the degradation reaction increases. The following reactions show the mechanism [64]: 
<smiles>O=C1C=CC(=O)C=C1</smiles>

$\mathrm{H}_{2} \mathrm{O}_{2} \longrightarrow 2 \mathrm{OH}^{\bullet}$

$\mathrm{H}_{2} \mathrm{O}_{2}+\mathrm{O}_{2} \longrightarrow 2 \mathrm{HO}_{2}{ }^{\bullet}$

Since the oxidation of phenol is very fast, the free radicals that will be produced form the phenol oxidation could also help to expedite the oxidation of benzene. 


\section{CHAPTER THREE \\ Experimental Setup and Procedure}

\subsection{Apparatus}

A schematic diagram of the experimental setup is shown in Figure 3.1. The setup consists of 3 main parts: the high pressure reactor, the electrically heated autoclave shell and the rocking mechanism. For safety reasons, the setup is placed inside a metal protective cage during the experiment. Figure 3.2 shows that the reactor consists of the bomb, the cap and the lid. The bomb itself is made of a 316 stainless steel and has a volume of $1.24 \mathrm{~L}$. The cap (Figure 3.3) contains 10 retention bolts and is fitted over the lid which is screwed tightly to the bomb. The lid that seals the bomb has 4 openings with a diameter of $5.50 \mathrm{~mm}$ to connect the gas inlet, the thermocouple, the pressure transducer and the sampling line. A micro sparger with a very fine opening is used to introduce the gas in the form of small bubbles. For heating purposes, the bomb is fitted inside the autoclave shell that contains a $1600 \mathrm{~W}$ heating coil and is rocked by a small motor through approximately thirty degrees to achieve a good mixing. The temperature is measured via a $\mathrm{J}$ type thermocouple, which sends the reading to the controller (Omega $\mathrm{CN} 8500$ ). In turn, the controller sends a signal to the autoclave heater. The temperature within the reactor is controlled to an accuracy of $\pm 2{ }^{\circ} \mathrm{C}$. The pressure transducer (Dynisco instruments Model PT-4626-5m) is designed for both high pressure and temperature and can be read from the digital pressure display. The capillary tubing is attached to the sampling line, which is well immersed in the reaction mixture. The unit is also equipped with the pressure safety valve. 
There are some design limitations associated with the experimental setup. The rocking mechanism has to be stopped while the bomb is facing downward when a liquid sample is withdrawn. This limits the number of samples that can be collected. Also, the heating time to the operating temperature is considerably long and there is no cooling mechanism. In addition the sampling tube must be immersed in an ice bath in order to collect the sample in a liquid phase and to condense all the volatile compounds in the sample.

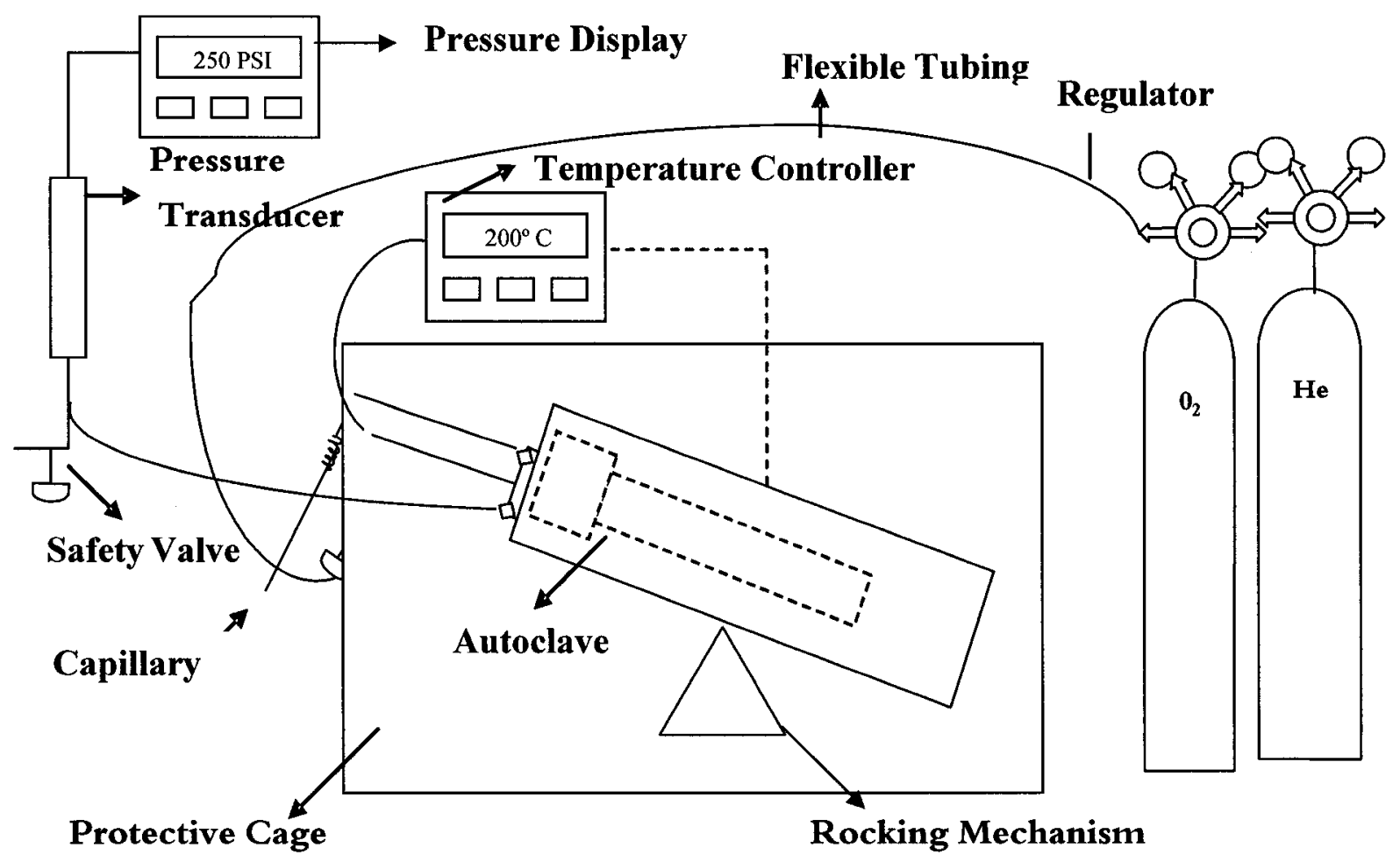

Figure 3.1: Schematic Diagram of the Experimental Setup. 


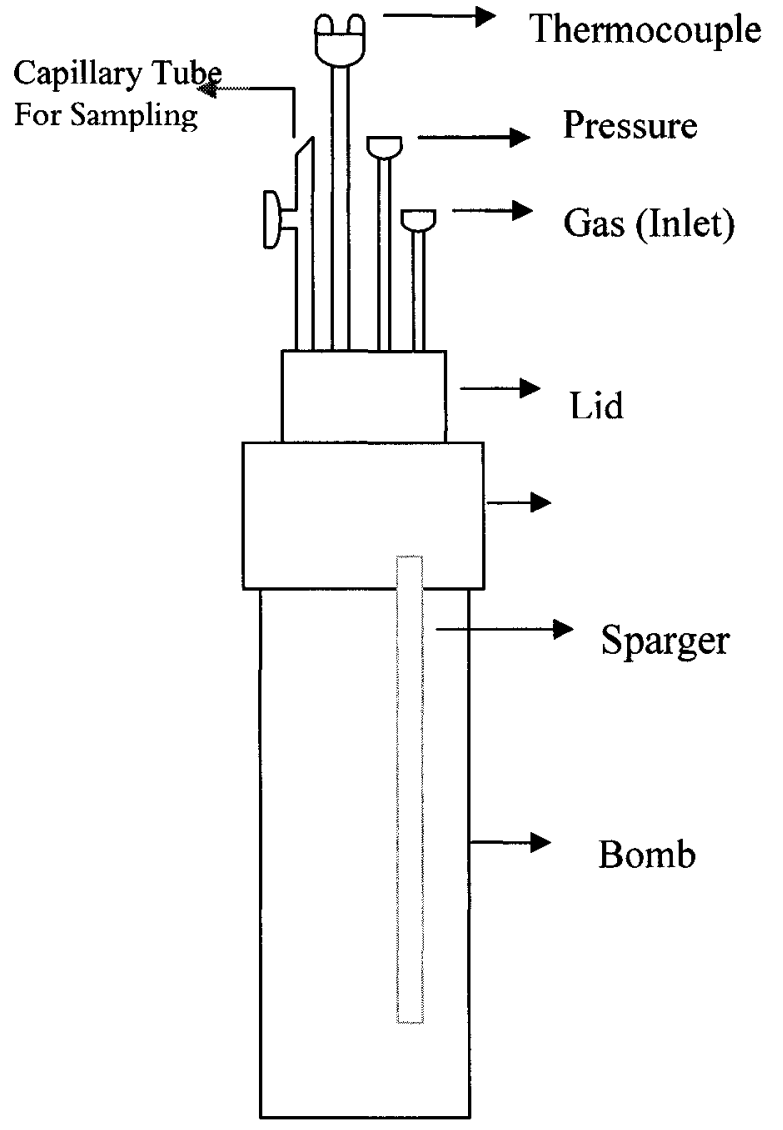

Figure 3.2: Schematic Diagram of the Reactor $\mathrm{ID}=8.2 \mathrm{~cm}, \mathrm{OD}=11.2 \mathrm{~cm}$, $\mathrm{L}=23.0 \mathrm{~cm}$.

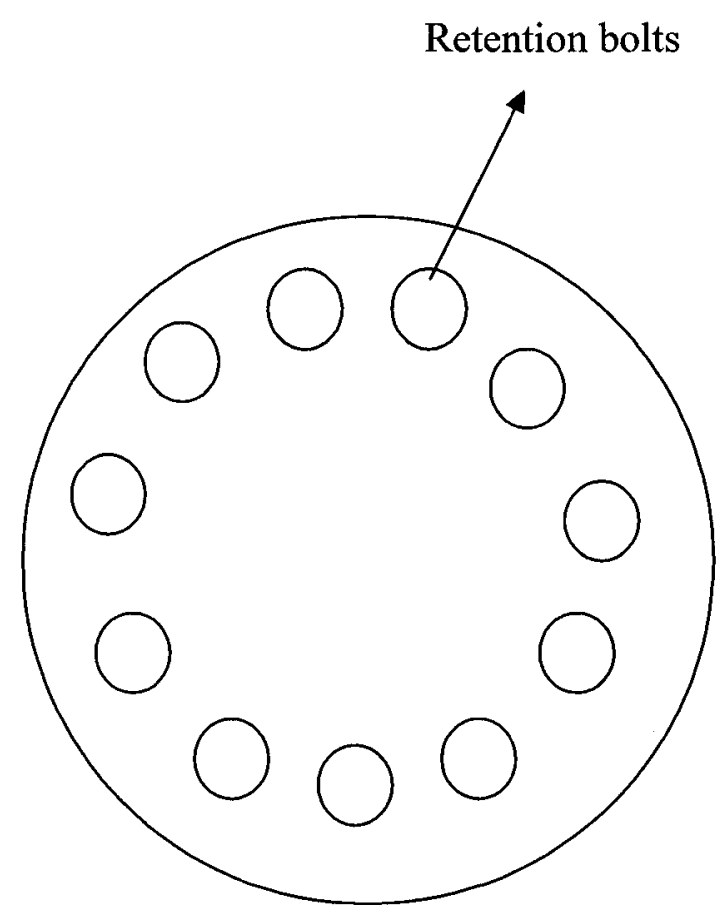

Figure 3.3: Upper View for the Cap

\subsection{Materials}

Benzene ACS grade was obtained from Fisher Scientific with a $99.9 \%$ purity and was used as received from the supplier. Toluene HPLC grade was obtained from American Chemicals LMD. Oxygen from a cylinder with a minimum purity of $99.6 \%$ was used as oxidant. Helium that is the inert gas used in the experiment was also used from a cylinder with a purity of $99 \%$. Both oxygen and helium were obtained from BOC Gases in Montreal, Canada. Phenol (ACS grade) was obtained from J.T Baker and used without further purification. Sulfuric acid and nitric acid were ACS grade and obtained 
Fisher Scientific. Formic acid (ACS grade) was obtained from American Chemicals LMD. Acetic acid (trace metal grade) was obtained from Fisher Scientific.

\subsection{Experimental Procedures}

Throughout the experiments, $500 \mu \mathrm{L}$ of benzene was added to $1000 \mathrm{~mL}$ of water and stirred for 1 hour. Since the benzene is a very dangerous and carcinogenic material, this was done in the fume hood and gloves were worn. The initial $\mathrm{pH}$ of the solution was in the range of 4-6. Depending on the desired initial value, the $\mathrm{pH}$ was typically lowered with nitric acid, but sulfuric acid or acetic acid were also used to determine if the type of acid has any influence on the reaction. The solution was then transferred to the reactor, which was then sealed at once. All auxiliary components were connected and the reactor was purged with helium to remove any oxygen in the reactor. Helium was added to the system before heating to prevent the oxidation before the reaction temperature was reached and to keep the effluent in the liquid phase. After that, the reactor was placed inside the autoclave that was pre-heated for about $60-75$ minutes to minimize the time needed to reach the operating temperature. Then, the system was heated to the predetermined operating temperature. The operating temperature was in the range of 190$260^{\circ} \mathrm{C}$. When the operating temperature was reached, the reactor was pressurized with pure $\mathrm{O}_{2}$ to the appropriate oxygen partial pressure. This was considered as time zero for the reaction. In all experiments the amount of oxygen was always in excess. Appendix A shows the calculation for the theoretical amount of oxygen needed. To collect a liquid sample from the reactor, the rocking mechanism was stopped, and with the bomb facing downward, the capillary tube was immersed in an ice bath. All collected samples were of 
the same volume and they were weighed and stored in the refrigerator. Toluene was added to each sample as an internal standard for the GC analysis of the benzene and the phenol. The above mentioned procedure was repeated at different temperatures and pressures. Usually, experiments were done in duplicate.

In the second part of this study, phenol was used to enhance the degradation of the benzene. Experiments were done with different phenol concentrations in the range of 10 to $200 \mathrm{mg} / \mathrm{L}$ with $100 \%$ excess of oxygen. In those experiments, the concentration of benzene was kept constant at $5.63 \mathrm{mmol} / \mathrm{L}$. The operating temperatures were in the range of $160-220^{\circ} \mathrm{C}$. After the preparation of the solution, the experimental procedure was exactly as it was described before.

\subsection{Analytical Methods}

The main analytical method that was used to study the effectiveness of the WAO method was Gas Chromatography (GC). It was used to measure the degree of oxidation for both benzene and phenol. Also, in some experiments the Total Organic Carbon (TOC) analysis was used to determine the carbon degradation. Ion Chromatography (IC) was used to study the production and the degradation of organic acids.

\subsubsection{Gas Chromatography Analysis}

Gas Chromatography is one of the most important separation methods, which is based on components partitioning between a stationary phase that can be either liquid or solid, and a mobile phase, which is an inert carrier gas. The column used in this work was 
bought from Chromatographic Specialties Inc. and it was a Stabilwax column 30 meter long with $0.32 \mathrm{~mm} \mathrm{ID}$ and $0.25 \mu \mathrm{m}$ df. The GC apparatus was a Hewlett Packard 5890.

\subsubsection{Gas Chromatography Method}

The injector temperature was set to $215^{\circ} \mathrm{C}$ while the FID detector temperature was set at $275^{\circ} \mathrm{C}$. The flow rates for the air, hydrogen, and helium were $300,30,30 \mathrm{~mL} / \mathrm{min}$, respectively. Before the analysis, the split ratio of helium was set to $10 \mathrm{~mL} / \mathrm{min}$ and the column temperature was set at $215^{\circ} \mathrm{C}$ for about an hour, in order to flush the column. Then, the temperature was reduced to $80^{\circ} \mathrm{C}$ as the initial temperature. The initial time was set to 2 minutes, after which the temperature was increased to $200^{\circ} \mathrm{C}$ at a rate of $20^{\circ} \mathrm{C} / \mathrm{min}$. The sample volume was $0.3 \mu \mathrm{L}$. Toluene was used as an internal standard because it has similar structure to benzene and has similar retention time. The use of internal standard is very important in order to minimize the error during the injection of the sample. When using an internal standard, the standard that contains known concentrations of both benzene and toluene was prepared. The standard was injected into the GC in order to calculate the $k$ factor which is defined as

$$
k=\frac{(\text { area / amount })_{C}}{(\text { area / amount })_{I}}
$$

where,

$[(\text { area/amount })]_{\mathrm{C}}$ : value of the compound

$[(\text { area/amount })]_{\mathrm{I}}:$ Value of the internal standard

This $k$ value is constant which is used to calculate the concentration of tested component. 


\subsubsection{Calibration of the GC}

Three benzene standards that contain the same benzene and toluene concentrations were prepared. Five $0.3 \mu \mathrm{L}$ samples from each standard were injected randomly in the GC. These 15 samples were used to calibrate the GC, which is done automatically by the instrument. After calibration, a sample from each standard was injected in order to check the calibration. The results that were obtained showed that the maximum deviation was $6.8 \%$. There are many sources that can lead to this deviation, such as error that results from the preparation of the standards, error that can results from the addition of the internal standard and instrument's error. It should be mentioned that for two injections from the same sample, the reading was close to each other with a difference less than $4 \%$ in most cases. This difference decreased for highly concentrated samples and increased when the concentration of the sample was less than $0.1 \mathrm{mmol} / \mathrm{L}$.

After the calibration of the GC apparatus, a repeatability of the standard was determined. A fresh standard with a known concentration was prepared and it was used to calibrate the GC. After calibration, two fresh standards that have the same concentration were prepared to check the repeatability of the results. It was found that the maximum deviation was $5.3 \%$

\subsubsection{Ion Chromatography}

Ion Chromatography (IC), which is a form of liquid chromatography, is an analytical method used to separate atomic or molecular ions by the use of ion exchange resins, and this is based on their interaction with the resin. In this study, IC was used mainly to determine the concentration of the molecular ions for both the acetate and formate. The 
IC used was the DX-100 which is manufactured by the Dionex Corporation. The column which was used is IonPac AS14 $4 \mathrm{~mm}$ while the eluent was $2.7 \mathrm{mmol} \mathrm{Na} \mathrm{CO}_{3} / \mathrm{L}+0.3$ mmol $\mathrm{NaHCO}_{3} / \mathrm{L}$. One limitation of this method was the poor separation between the acetic acid and the formic acid, due to the isocratic technique that was used. In this technique, the solvent composition remains constant throughout the analysis since no gradient pump was used to change the concentration of the eluent after certain time, which is important to achieve better separation. This problem was overcome by using a slow pump speed in order to get better separation.

\subsubsection{Ion Chromatography Method}

Standards with different concentrations for both acetic acid and formic acid were prepared. A calibration curve for each acid was produced and stored in the IC program. The pump speed was adjusted to $50 \mathrm{~mL} / \mathrm{min}$ and the eluent nitrogen pressure was adjusted to $68.9 \mathrm{kPa}$. A blank was injected to check for any contaminants that may be present in the column. $1.0 \mathrm{~mL}$ of the sample was injected in the column after which the values of the acids were recorded.

\subsubsection{Repeatability of the IC}

Five different standards with five different concentrations of both acetic and formic acids were prepared for the IC calibration. After calibration, fresh standards of both acetic acid and formic acid were prepared and were injected to check the validity of the IC calibration. The results showed that the calibration was good and the error was less than $3 \%$. To study the calibration of a mixture of both acetic and formic acids, a fresh 
standard that contained a known concentration of both acids was prepared and injected in the IC. The results show that the calibration was good even for the mixtures. For example, when a standard that contain $60 \mathrm{mmol} / \mathrm{L}$ formic acid and $20 \mathrm{mmol} / \mathrm{L}$ acetic acid was prepared and injected in the IC after calibration, the results that were obtained were $59.4 \mathrm{mmol} / \mathrm{L}$ for formic acid and 19.6 for acetic acid. The same results were obtained even if only formic or acetic acid was injected.

\subsubsection{Total Organic Compound Measurement}

Total Organic Carbon analysis is a method that measures the carbon content of dissolved organic matter present in a solution and it is a common parameter that can describe the efficiency of the treatment process. TOC does not measure any organically bound elements other than carbon and it does not depend on the oxidation state of the organic matter. Also, TOC does not measure the inorganic compounds, which may contribute to the oxygen demand as measured by Chemical Oxygen Demand analysis (COD). For this study, the UV-Persulfate method was used. The organic compounds

were oxidized to carbon dioxide by persulphate in the presence of a UV light source. A nondispersive infrared analyzer measured the $\mathrm{CO}_{2}$ generated during the reaction. The apparatus that was used for the TOC measurement was the DC-80 Total Carbon Analyzer manufactured by Rose Mount Dohrmann.

\subsubsection{TOC Method}

Before the measurement, the TOC analyzer was calibrated with a $400 \mathrm{mg} / \mathrm{L}$ standard of Potassium Hydrogen Phthalate (KPH). After calibration, the sample was injected with 
a $200 \mu \mathrm{L}$ syringe into the apparatus. All samples were injected with both lamp on and lamp off. When the lamp was on, the results included both Total Organic Carbon and Total Inorganic Carbon, while with the lamp off, only the Total Inorganic Carbon was detected. Then, the TOC was calculated as the difference between the two values. This has been done in order to minimize any error that may occur because of the interference of the inorganic compounds. The repeatability of the TOC analysis was tested by 10 injections for the same sample and the standard deviation was found to be $2.95 \%$. 


\section{CHAPTER FOUR \\ RESULTS AND DISCUSSIONS \\ WET AIR OXIDATION OF BENZENE}

The wet air oxidation of benzene was studied to determine the optimum conditions required to achieve benzene degradation. The effect of initial $\mathrm{pH}$ on the degradation of benzene has been studied at different temperatures and pressures. Results from experiments that have been performed in the absence of oxygen are presented. The repeatability of the results was tested. The $\mathrm{pH}$ fluctuation during the experiment was also shown. Both the effect of acidification method and the effect of the initial benzene concentration on its degradation were examined. Finally, a simple kinetic model was proposed.

\subsection{Experiments with Benzene in the Absence of Oxygen}

At the beginning of this study, two experiments were carried out without oxygen using only nitrogen to determine whether any pyrolysis of the benzene took place. These two experiments were done under 1.1 MPa nitrogen pressure with $11.3 \mathrm{mmol} / \mathrm{L}$ benzene solution at $20^{\circ} \mathrm{C}$ and $250^{\circ} \mathrm{C}$. In the absence of oxygen, no degradation was observed. These experiments also showed that the sampling procedure did not have any effect on the liquid concentration and the benzene stayed in the liquid phase throughout the experiment. 


\subsection{Chemical Oxygen Demand Measurements}

Chemical Oxygen Demand (COD) is one of the most widely used parameters to evaluate the degree of oxidation during the WAO. At the beginning of this study, the COD was one of the parameters used to study the extent of degradation of organic compound. However, the results showed that benzene was not completely oxidized under the conditions of the COD test. This observation is in agreement with the literature (2). For example, when the benzene concentration was $4.52 \mathrm{mmol} / \mathrm{L}$, the equivalent $\mathrm{COD}$ concentration should have been $33.9 \mathrm{mmol} \mathrm{O}_{2} / \mathrm{L}$. In fact, the actual COD value measured was $26.6 \mathrm{mmol} \mathrm{O}_{2} / \mathrm{L}$. Therefore, in this thesis the results will be reported in terms of the concentrations of benzene, byproducts and the total organic carbon.

\subsection{Repeatability of the Results}

Repeatability of the experimental results has been tested by conducting duplicate experiments. The majority of the data points that will be shown in this chapter are averages of two experiments. Figures 4.1, 4.2 and 4.3 demonstrate the repeatability of the experimental points obtained at oxygen pressure of $1.38 \mathrm{MPa}, \mathrm{pH} 4$ and temperatures of 220,240 and $260^{\circ} \mathrm{C}$, respectively. It is apparent that excellent repeatability has been achieved. 


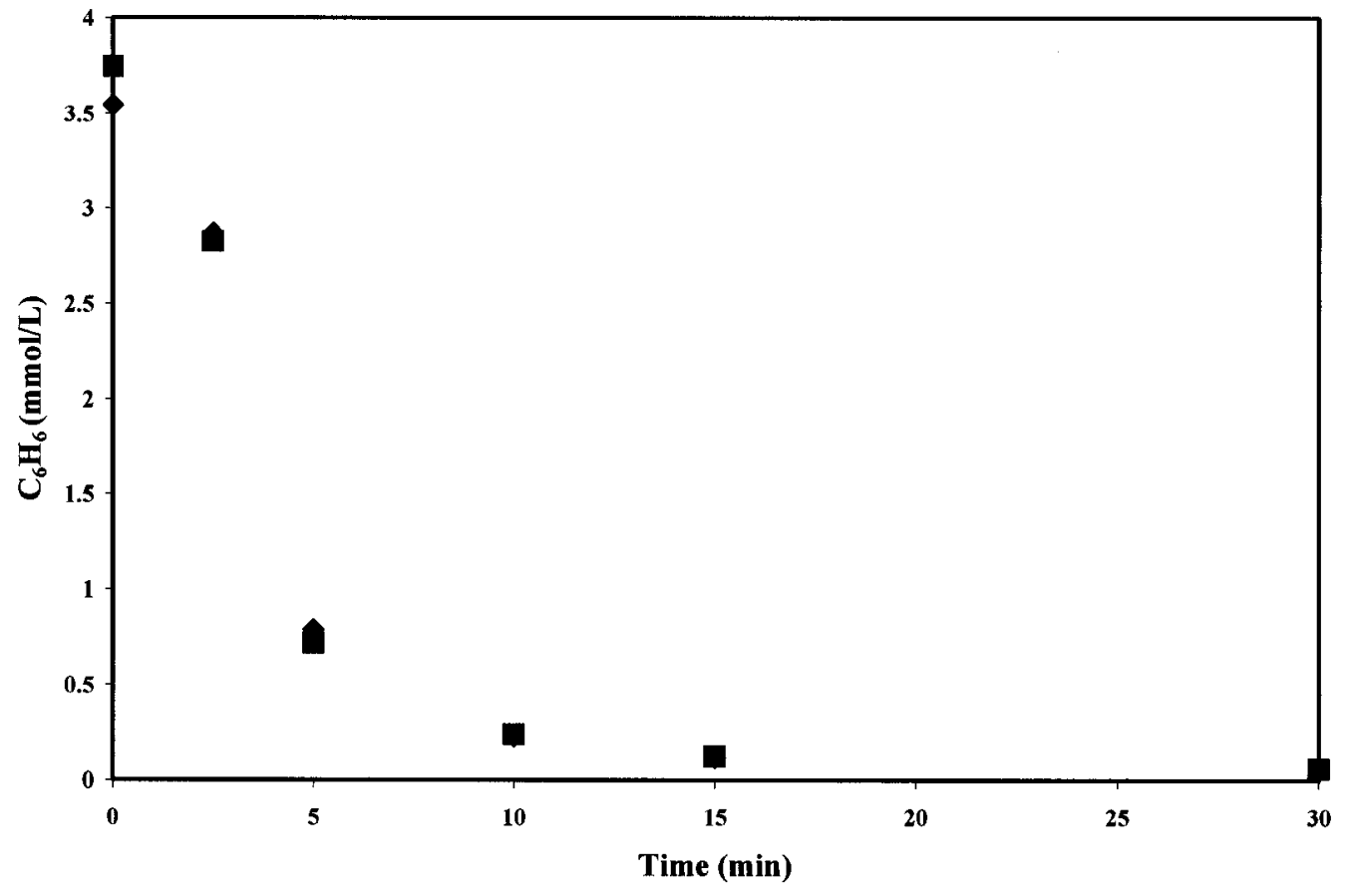

Figure 4.1: Repeatability of Data from Two Experiments at $220^{\circ} \mathrm{C}, \mathrm{P}_{\mathrm{O} 2}=1.38 \mathrm{MPa}, \mathrm{pH}=4$.

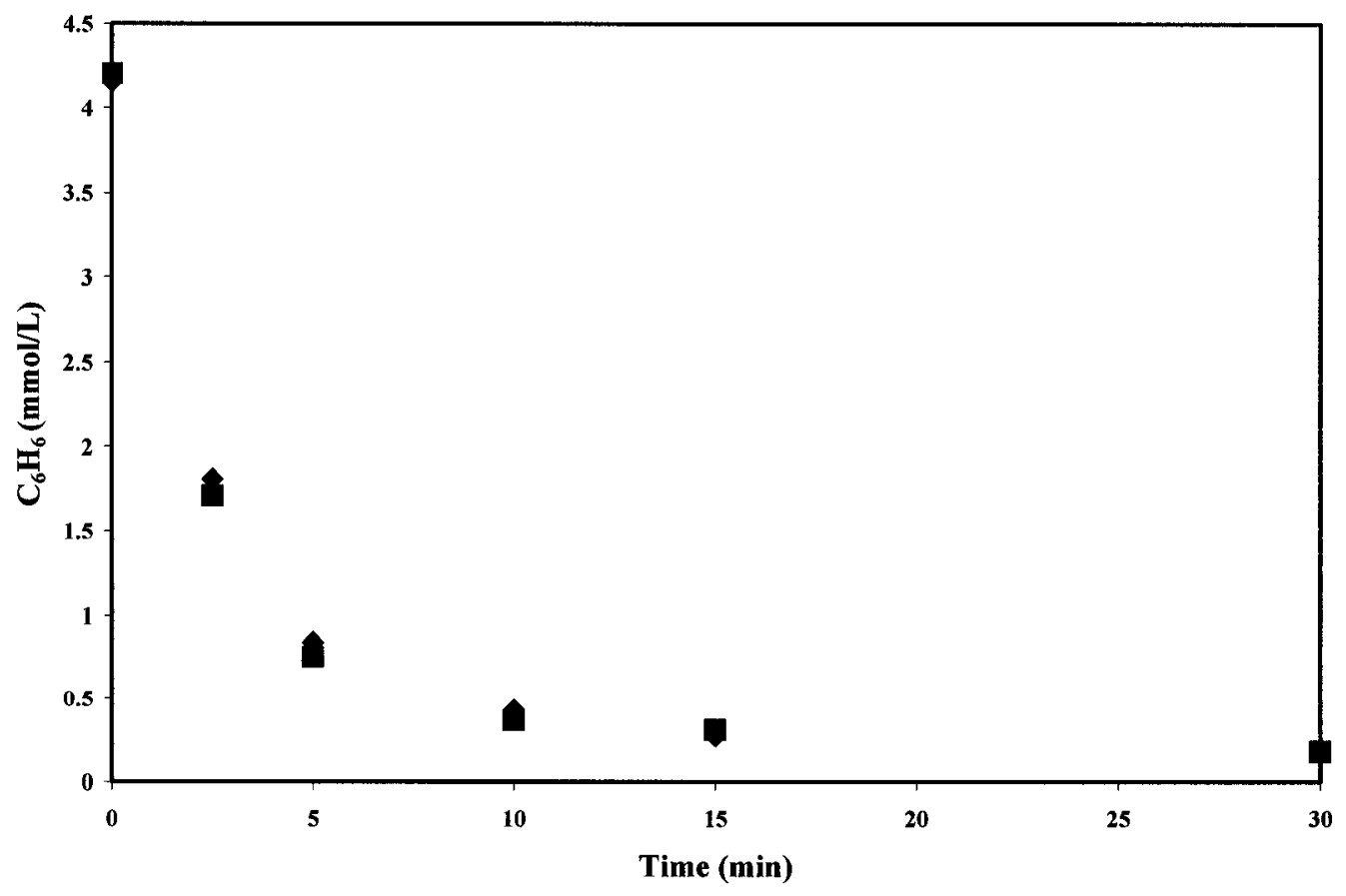

Figure 4.2: Repeatability of Data from Two Experiments at $240^{\circ} \mathrm{C}, \mathrm{P}_{\mathrm{O} 2}=1.38 \mathrm{MPa}, \mathrm{pH}=4$. 


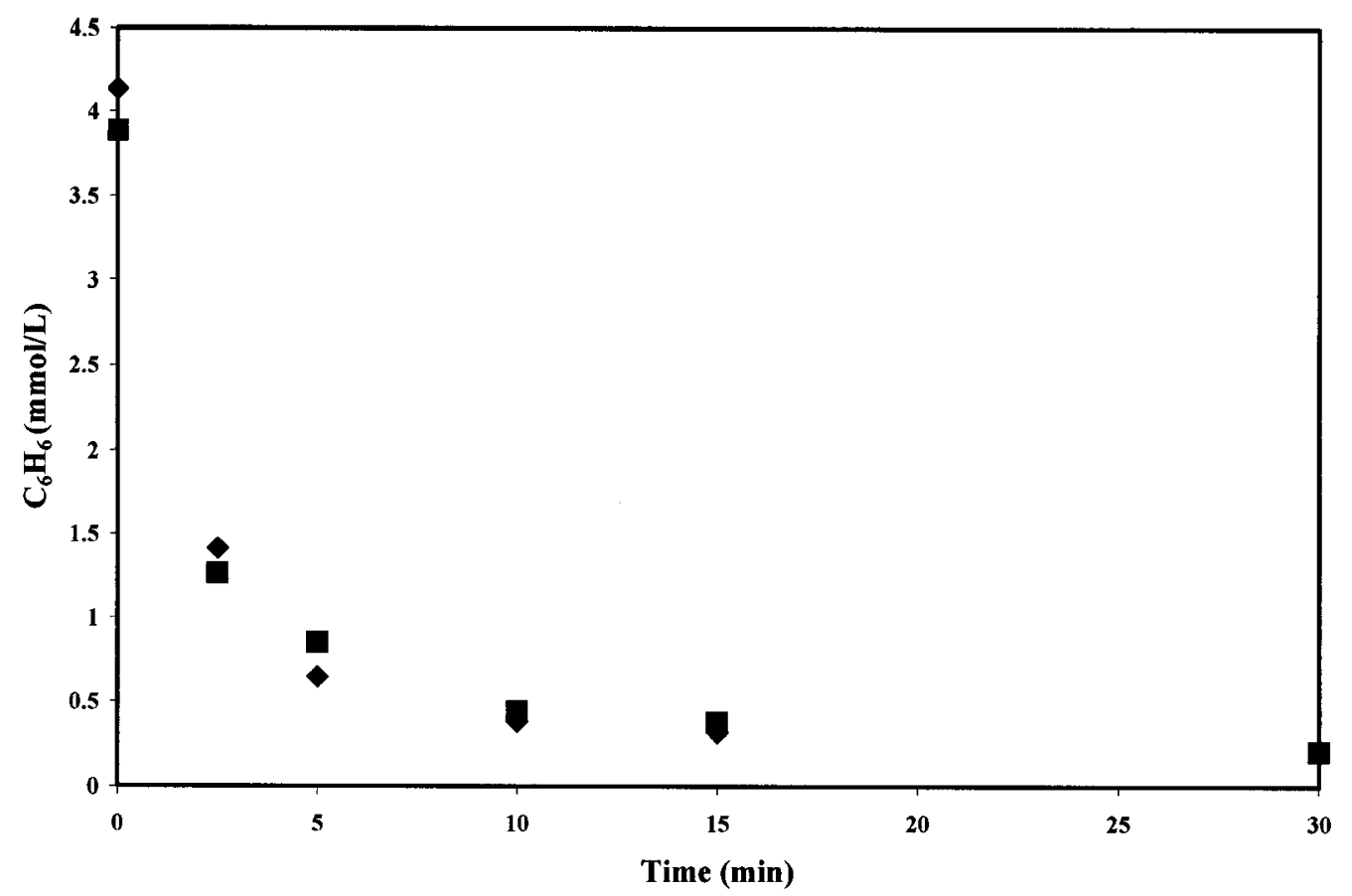

Figure 4.3: Repeatability of Data from Two Experiments at $260^{\circ} \mathrm{C}, \mathrm{P}_{\mathrm{O} 2}=1.38 \mathrm{MPa}, \mathrm{pH}=4$.

\subsection{Influence of Initial pH on Benzene Degradation}

In this section, the effect of initial $\mathrm{pH}$ at four different temperature levels at $190^{\circ} \mathrm{C}$, $220^{\circ} \mathrm{C}, 240^{\circ} \mathrm{C}$ and $260^{\circ} \mathrm{C}$ was studied. The oxygen pressure was kept constant at 1.38 $\mathrm{MPa}$. Two experiments were conducted at $190^{\circ} \mathrm{C}$. The initial $\mathrm{pH}$ was 4 and 6 . Figure 4.4 demonstrates that when the initial $\mathrm{pH}$ was 6 , almost no degradation took place even after 5 hours of oxidation time. However, when the initial $\mathrm{pH}$ was lowered to 4 about $98 \%$ degradation was achieved within 1 hour.

Figure 4.5 shows the effect of the initial $\mathrm{pH}$ on the benzene degradation at $220^{\circ} \mathrm{C}$. When the initial $\mathrm{pH}$ was reduced from 6 to 5 the reaction became faster. However, when the initial $\mathrm{pH}$ was reduced from 5 to 4 the change in the reaction rate was only noticeable at the first 2.5 minutes and after that the results were similar. The induction time 
decreased with $\mathrm{pH}$ from 50 minutes to 2.5 minutes when the $\mathrm{pH}$ was decreased from 6 to 5. At $\mathrm{pH} 4$, the induction time disappeared suggesting that at lower $\mathrm{pH}$ there was much higher accumulation of the free radicals, which helped to initiate the oxidation even faster. During the course of the reaction and because of the intermediates that were produced, the $\mathrm{pH}$ of the reaction medium kept changing continuously. At the beginning of the reaction, due to the production of acetic and formic acid (See Chapter 5), the $\mathrm{pH}$ decreased to around 3. When the acids started to oxidize, the $\mathrm{pH}$ increased again (This change in $\mathrm{pH}$ will be presented in Section 4.4.7 in more detail). However, in almost all cases the final $\mathrm{pH}$ of the solution was about 4 , mainly because of the acetic acid that remained as a final product as will be explained later.

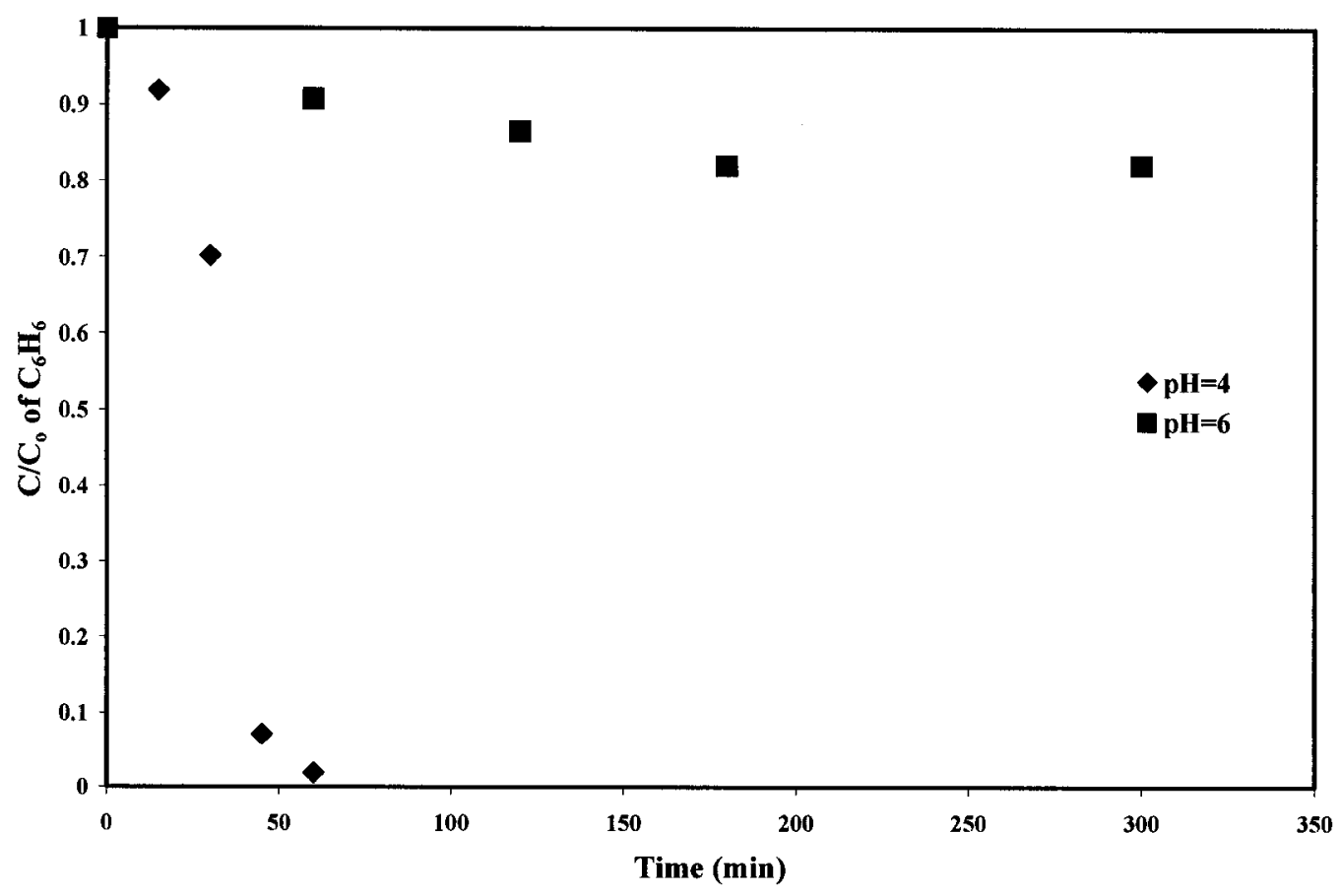

Figure 4.4: Effect of $\mathrm{pH}$ on Benzene Degradation at $190^{\circ} \mathrm{C}, \mathrm{P}_{\mathrm{O} 2}=1.38 \mathrm{MPa}$. 


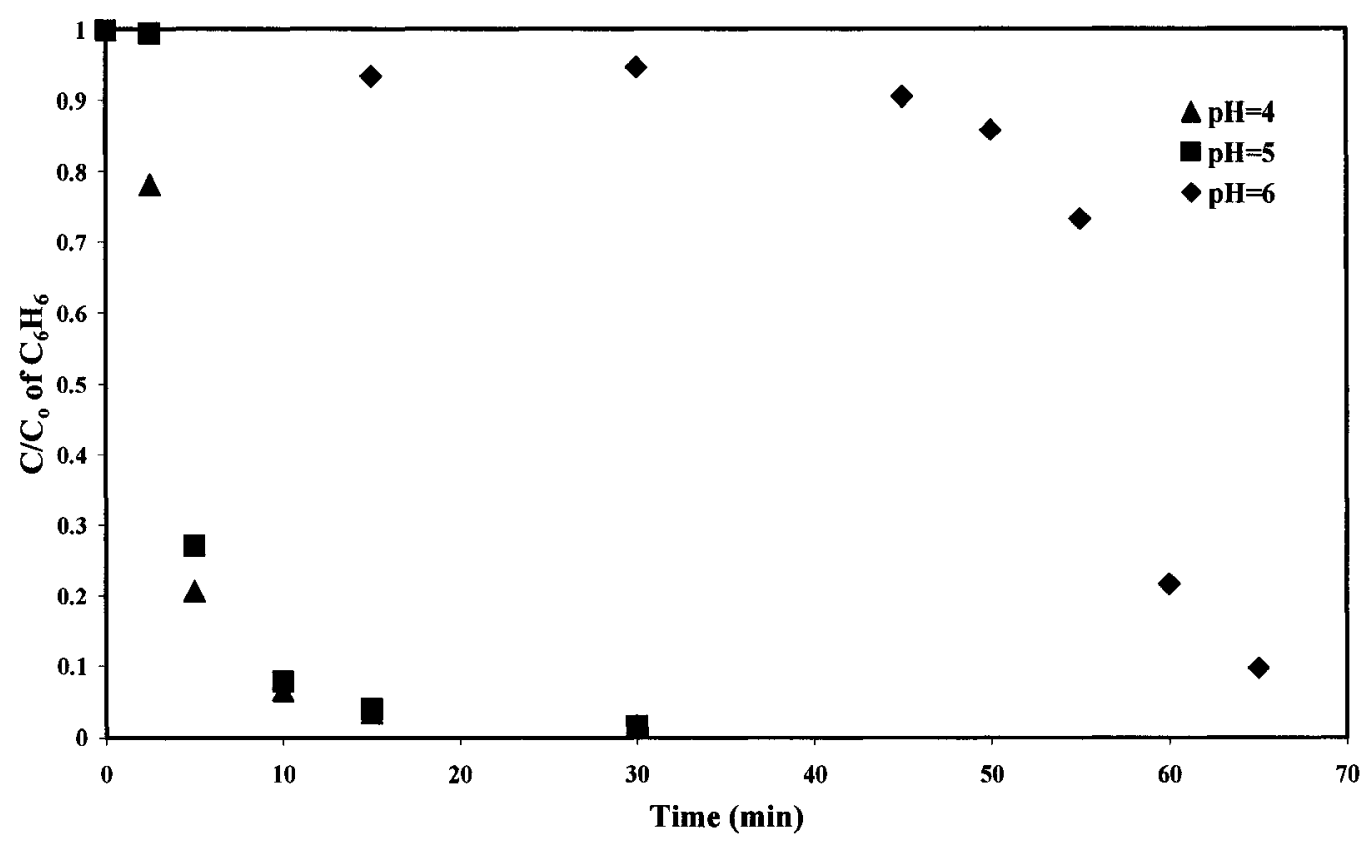

Figure 4.5: Effect of $\mathrm{pH}$ on the Benzene Degradation at $220^{\circ} \mathrm{C}, \mathrm{P}_{\mathrm{O} 2}=1.38 \mathrm{MPa}$.

Similarly, at $240^{\circ} \mathrm{C}$ (Figure 4.6), reducing the $\mathrm{pH}$ from 6 to 5 had a large effect on the degradation of benzene. The induction time, which was about 15 minutes at $\mathrm{pH} 6$, disappeared entirely at $\mathrm{pH} 5$ and $\mathrm{pH} 4$. Also, reducing the $\mathrm{pH}$ from 5 to 4 did not change the benzene degradation at this temperature, suggesting that at $240^{\circ} \mathrm{C}$ the accumulation of the free radicals at both $\mathrm{pH} 4$ and $\mathrm{pH} 5$ was comparable.

The effect of $\mathrm{pH}$ was further studied at $260^{\circ} \mathrm{C}$ where the oxidation was fast even in the first 5 minutes of the experiment. Figure 4.7 shows the degradation at $260^{\circ} \mathrm{C}$ at both $\mathrm{pH} 4$ and $\mathrm{pH}$ 6. The degradation of benzene was enhanced dramatically especially at the beginning of the reaction. While only $48 \%$ degradation was achieved at $\mathrm{pH} 6$ in the first 2.5 minutes, about $67 \%$ has been achieved at $\mathrm{pH} 4$.

In summary, the initial $\mathrm{pH}$ of the reaction medium had a significant effect on the benzene oxidation; especially at lower oxidation temperatures, because the $\mathrm{pH}$ of the solution influences the type of free radical reactions that occur and also the stability of 
the free radical intermediates formed (See Section 2.3). This confirms what was reported in the literature [6].

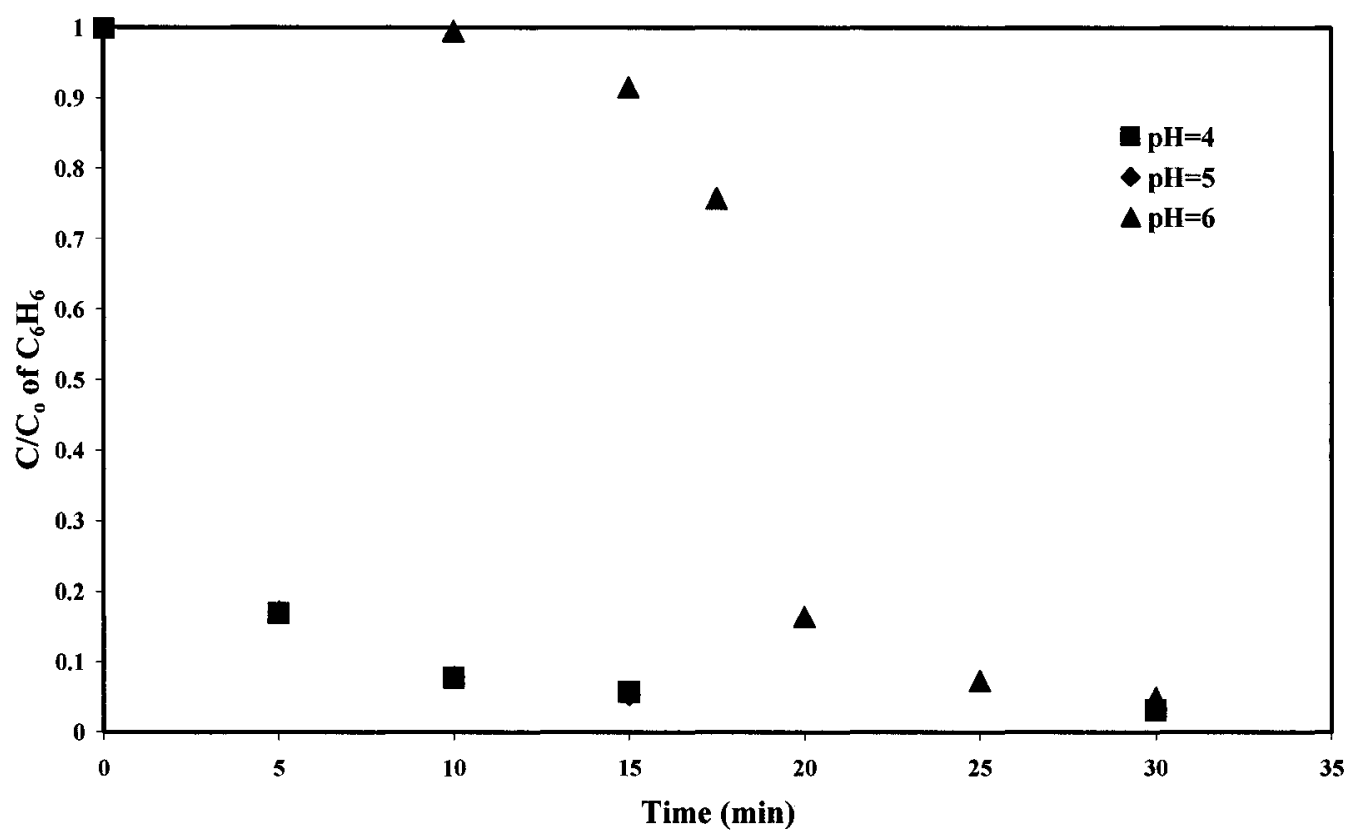

Figure 4.6: Effect of $\mathrm{pH}$ on the Benzene Degradation at $240^{\circ} \mathrm{C}, \mathrm{P}_{\mathrm{O} 2}=1.38 \mathrm{MPa}$.

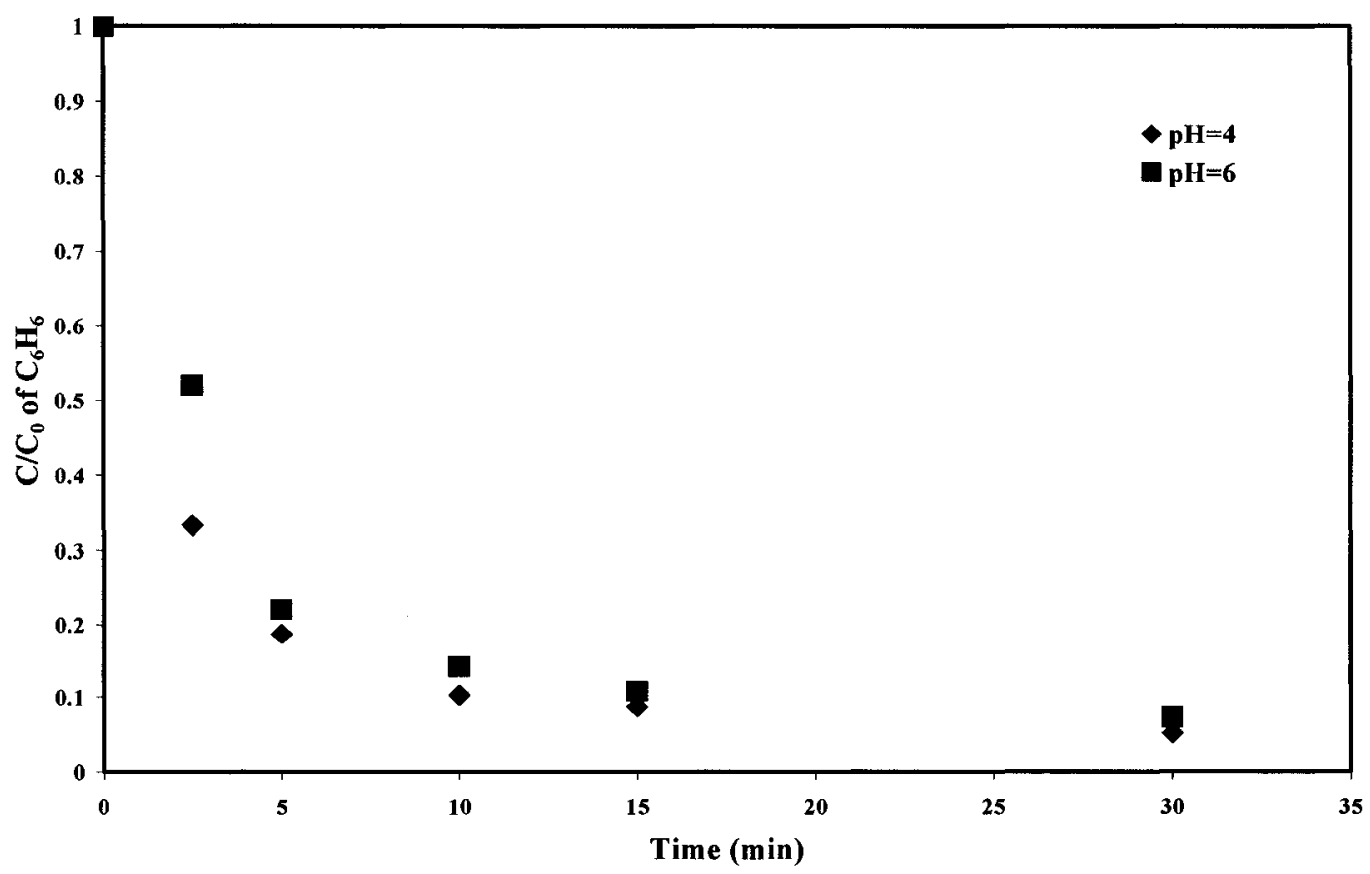

Figure 4.7: Effect of $\mathrm{pH}$ on the Benzene Degradation at $260^{\circ} \mathrm{C}, \mathrm{P}_{\mathrm{O} 2}=1.38 \mathrm{MPa}$. 


\subsubsection{Effect of Temperature on Degradation of Benzene at pH 6}

Based on the results of the previous section, further experiments were carried out at two different temperature ranges: (a) high temperatures $\left(220^{\circ} \mathrm{C}, 240^{\circ} \mathrm{C}\right.$ and $\left.260^{\circ} \mathrm{C}\right)$ and (b) low temperatures $\left(200^{\circ} \mathrm{C}\right.$ and $\left.210^{\circ} \mathrm{C}\right)$. The oxygen pressure was kept constant at 1.38 $\mathrm{MPa}$ at given temperature.

Figure 4.8 shows the normalized concentration of benzene at $220^{\circ} \mathrm{C}, 240^{\circ} \mathrm{C}$ and $260^{\circ} \mathrm{C}$, respectively. The results shown in this figure are the averages of duplicate experiments. At $260^{\circ} \mathrm{C}, 92 \%$ degradation was achieved within 15 minutes, compared to $26 \%$ at $240^{\circ} \mathrm{C}$ in 15 minutes and only $12 \%$ at $220^{\circ} \mathrm{C}$ after 30 minutes. However, more than $97 \%$ degradation was achieved in one hour at all temperatures and degradation of about 99\% was achieved after 3 hours (Figure 4.9). The experiments also show that taking a sample every 15 minutes was not sufficient to describe the decrease of benzene concentration. Therefore, in the next set of experiments samples were taken more frequently at the beginning of the experiments. Figure 4.9 shows an excellent repeatability of the experimental data at $240^{\circ} \mathrm{C}$.

In two experiments at $260^{\circ} \mathrm{C}$, a gas sample was collected at the end of the experiment after the bomb was cooled to room temperature. The purpose of this analysis was to ensure that there would not be a considerable amount of benzene in the gas phase. The gas sample was analyzed using the GC. The amount of benzene in the gas phase was found negligible, i.e. less than $0.03 \mathrm{mmol}_{6} \mathrm{H}_{6} / \mathrm{L}$.

Eight experiments were done at $200^{\circ} \mathrm{C}$ and four experiments at $210^{\circ} \mathrm{C}$. The results were very scattered (Figures 4.10 and 4.11). The only reason that can explain this is that 
this may be near the border temperature at which the activation energy may be high and a small increase in the temperature may ignite the reaction.

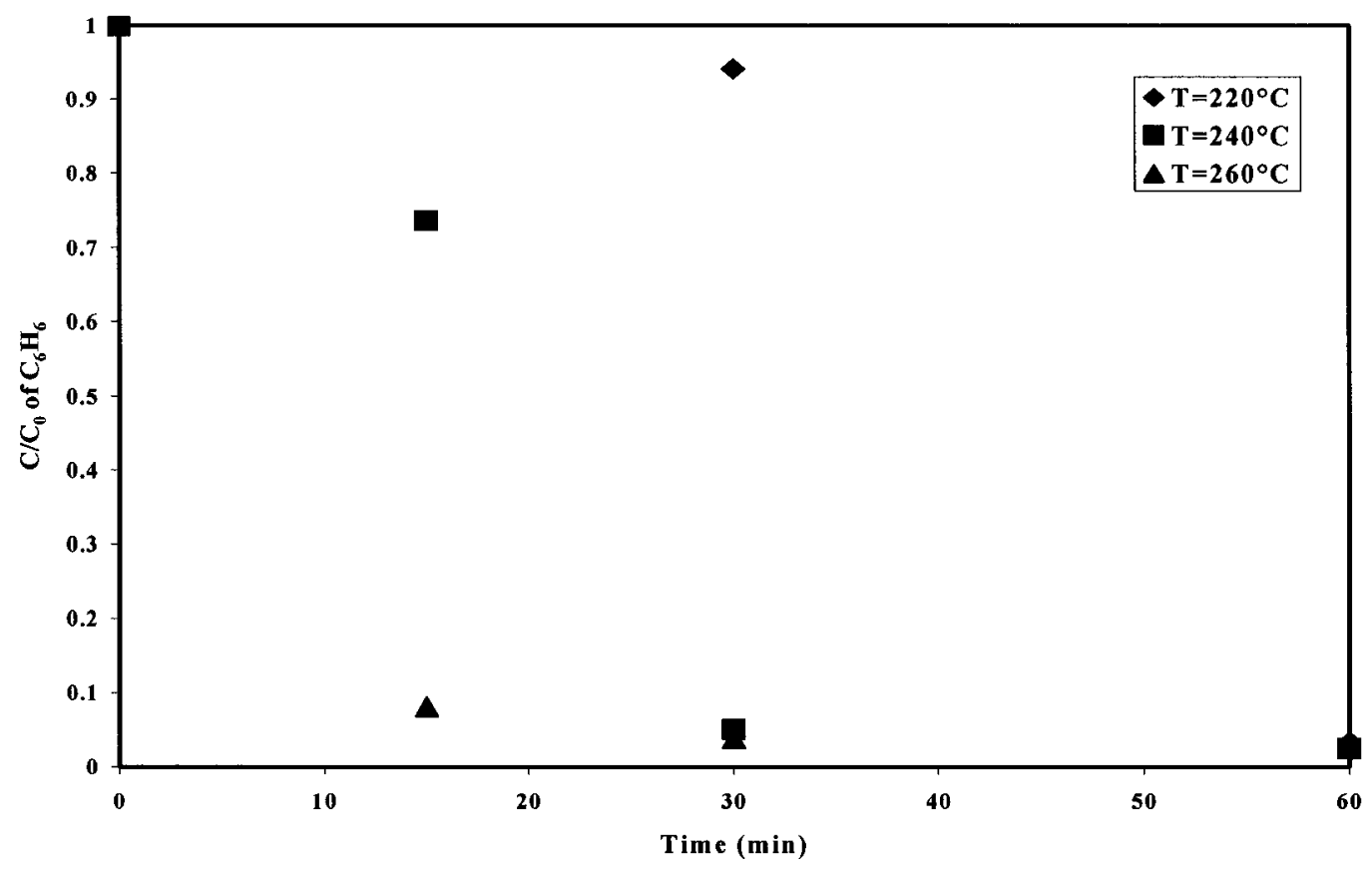

Figure 4.8: Degradation of Benzene at Different Temperatures, $\mathrm{P}_{\mathrm{O} 2}=1.38 \mathrm{MPa}, \mathrm{pH}=6$.

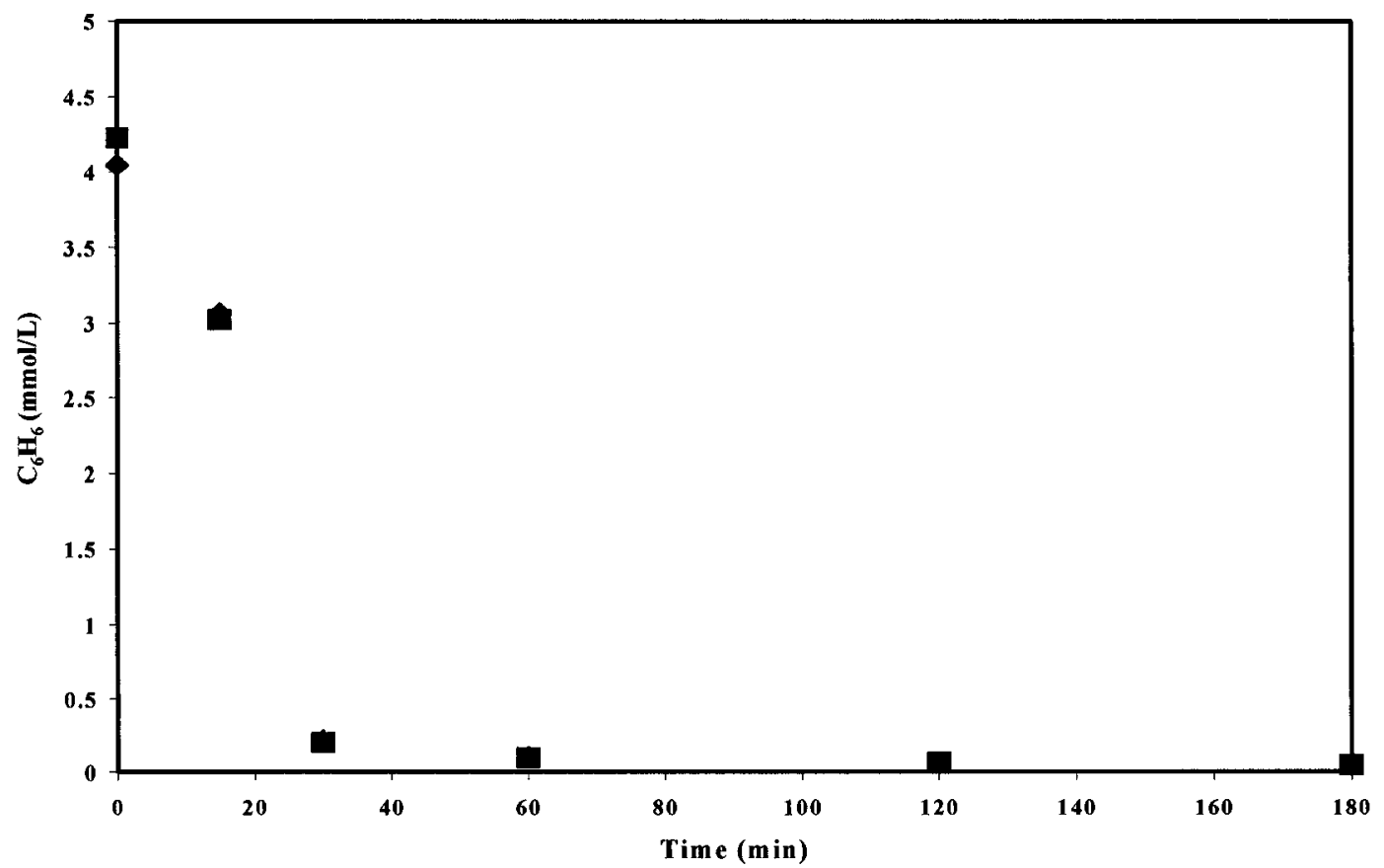

Figure 4.9: Repeatability of Data from Two Experiments at $240^{\circ} \mathrm{C}, \mathrm{P}_{\mathrm{O} 2}=1.38 \mathrm{MPa}, \mathrm{pH}=6$. 


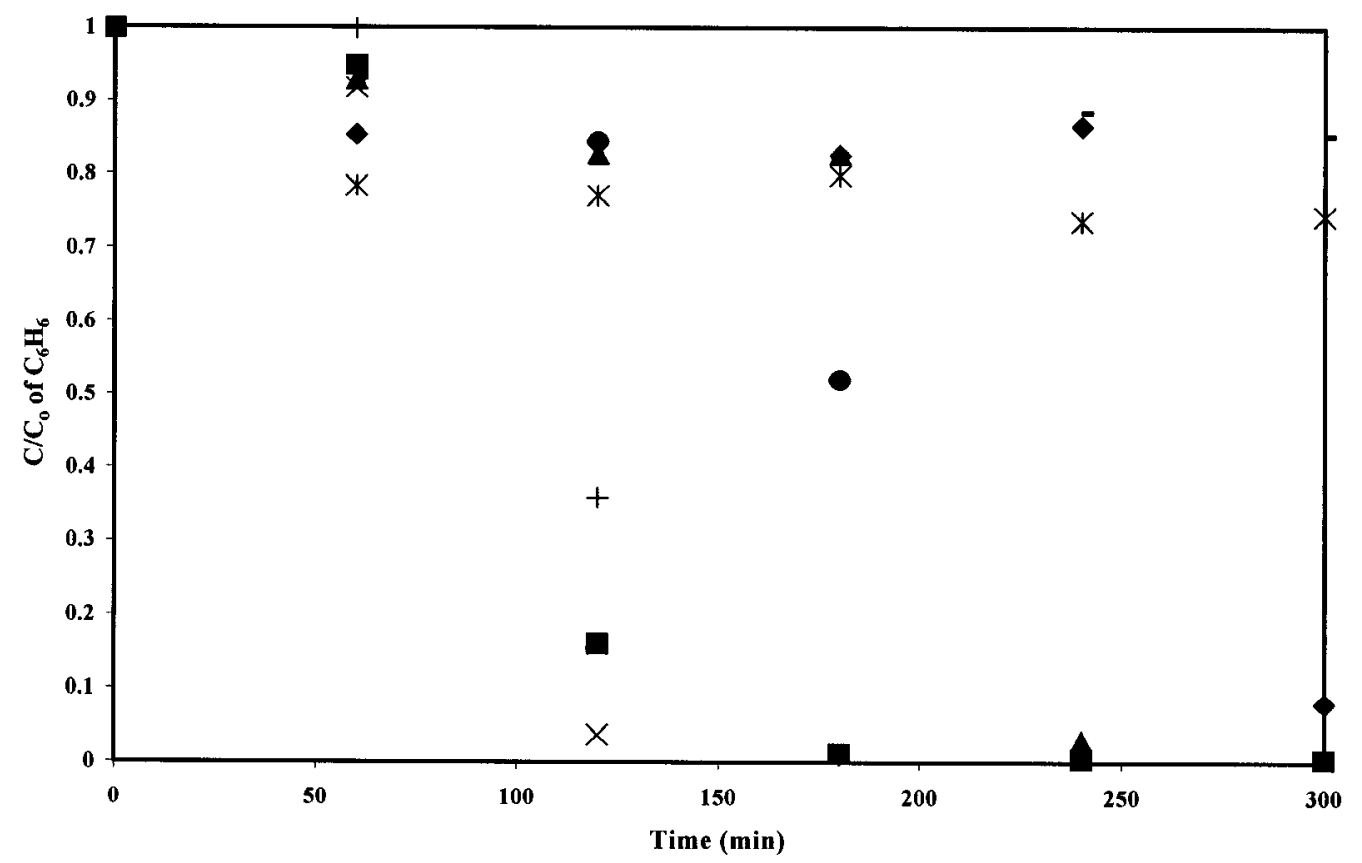

Figure 4.10: Degradation of Benzene at $200^{\circ} \mathrm{C}, \mathrm{P}_{\mathrm{O} 2}=1.38 \mathrm{MPa}, \mathrm{pH}=6$.

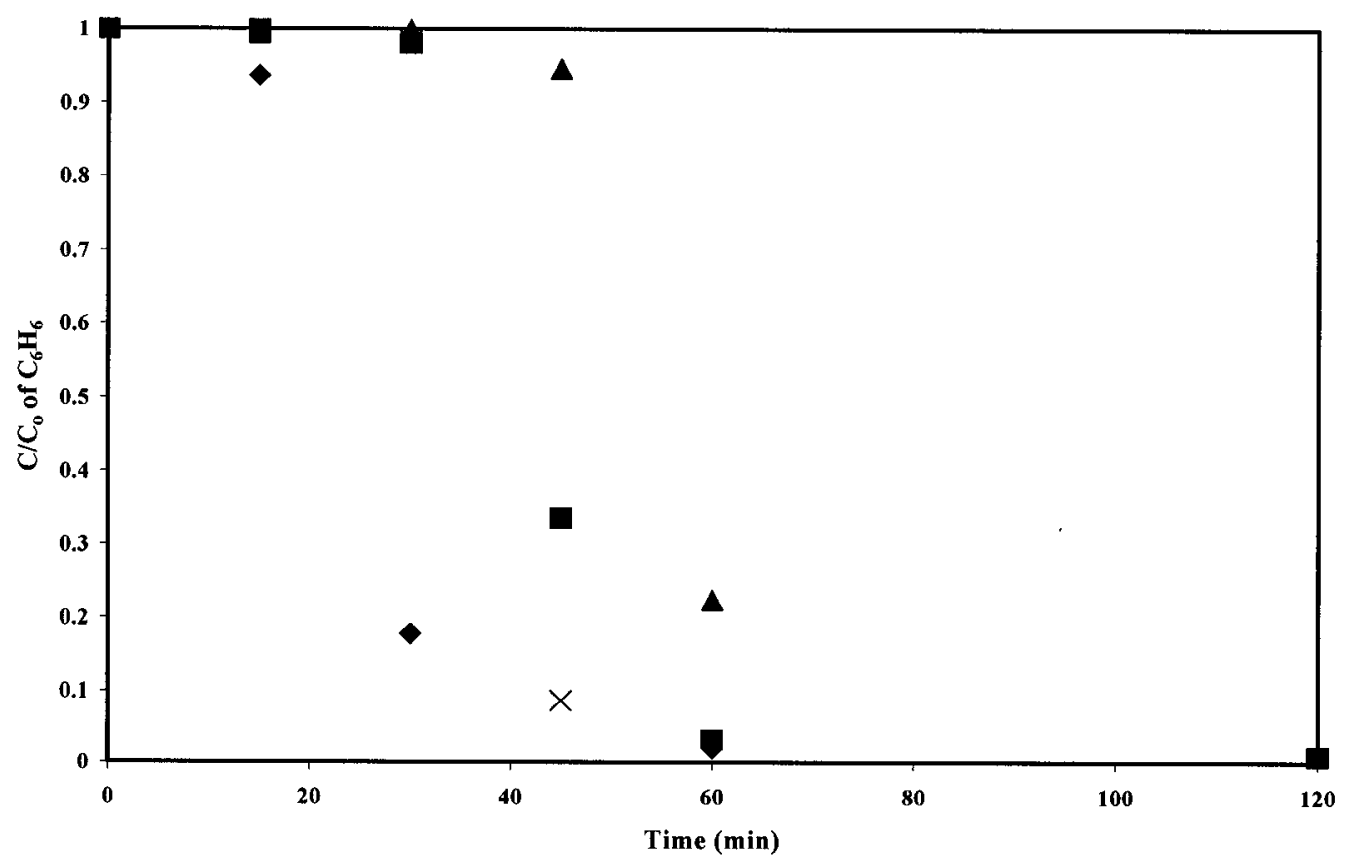

Figure 4.11: Degradation of Benzene at $210^{\circ} \mathrm{C}, \mathrm{P}_{\mathrm{O} 2}=1.38 \mathrm{MPa}, \mathrm{pH}=6$. 
The results that were obtained during the preliminary experiments led us to decide to work with the high temperatures range (from $220-260^{\circ} \mathrm{C}$ ), at which more samples were collected at each run. In those experiments, the oxygen pressure was kept constant at 1.38 $\mathrm{MPa}$ at given temperature. The initial $\mathrm{pH}$ of the solution was 6 . Figure 4.12 shows the degradation of benzene at $220^{\circ} \mathrm{C}, 230^{\circ} \mathrm{C}, 240^{\circ} \mathrm{C}, 250^{\circ} \mathrm{C}$ and $260^{\circ} \mathrm{C}$, respectively. As expected the degradation of benzene became faster with the increasing temperature. The reaction consisted of three steps; induction, fast reaction, and the termination. This is a typical pattern of the reactions governed by the free radical mechanism (See Chapter 2). During the induction time there was an accumulation of the hydroxyl radicals and as soon as there was a sufficient amount of hydroxyl radicals, the reaction proceeded quickly until most of the reactant was oxidized [69]. Then the rate of reaction decreased until the oxidation was complete. As the temperature increased the induction time decreased until it almost disappeared at $250^{\circ} \mathrm{C}$.

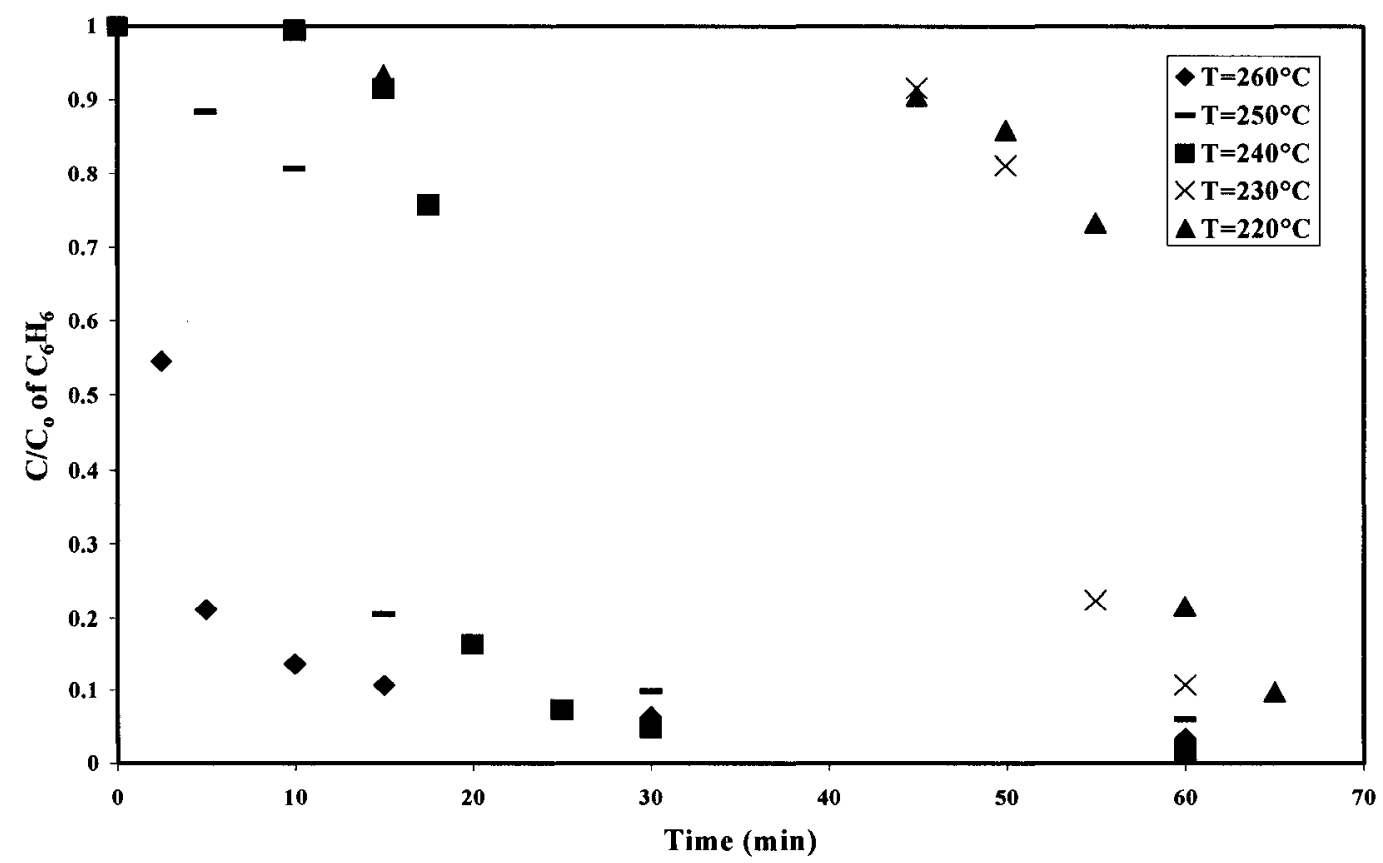

Figure 4.12: Degradation of Benzene at Different Temperatures, $\mathrm{P}_{\mathrm{O} 2}=1.38 \mathrm{MPa}, \mathrm{pH}=6$. 


\subsubsection{Effect of Oxygen Pressure on Benzene Degradation at pH 6}

The effect of pressure was studied at $260^{\circ} \mathrm{C}$ and the samples were collected periodically during the experiment and at the end of the experiment. Figure 4.13 shows the degradation of $\mathrm{C}_{6} \mathrm{H}_{6}$ at two different pressures. It was found that $99 \%$ degradation was achieved in just 15 minutes when the pressure was $5.52 \mathrm{MPa}$ while only $86 \%$ was reached when the pressure was $1.38 \mathrm{MPa}$. However, the difference became negligible after 3 hours. The main reason is that at the higher oxygen pressure the solubility of the oxygen in the liquid phase increases.

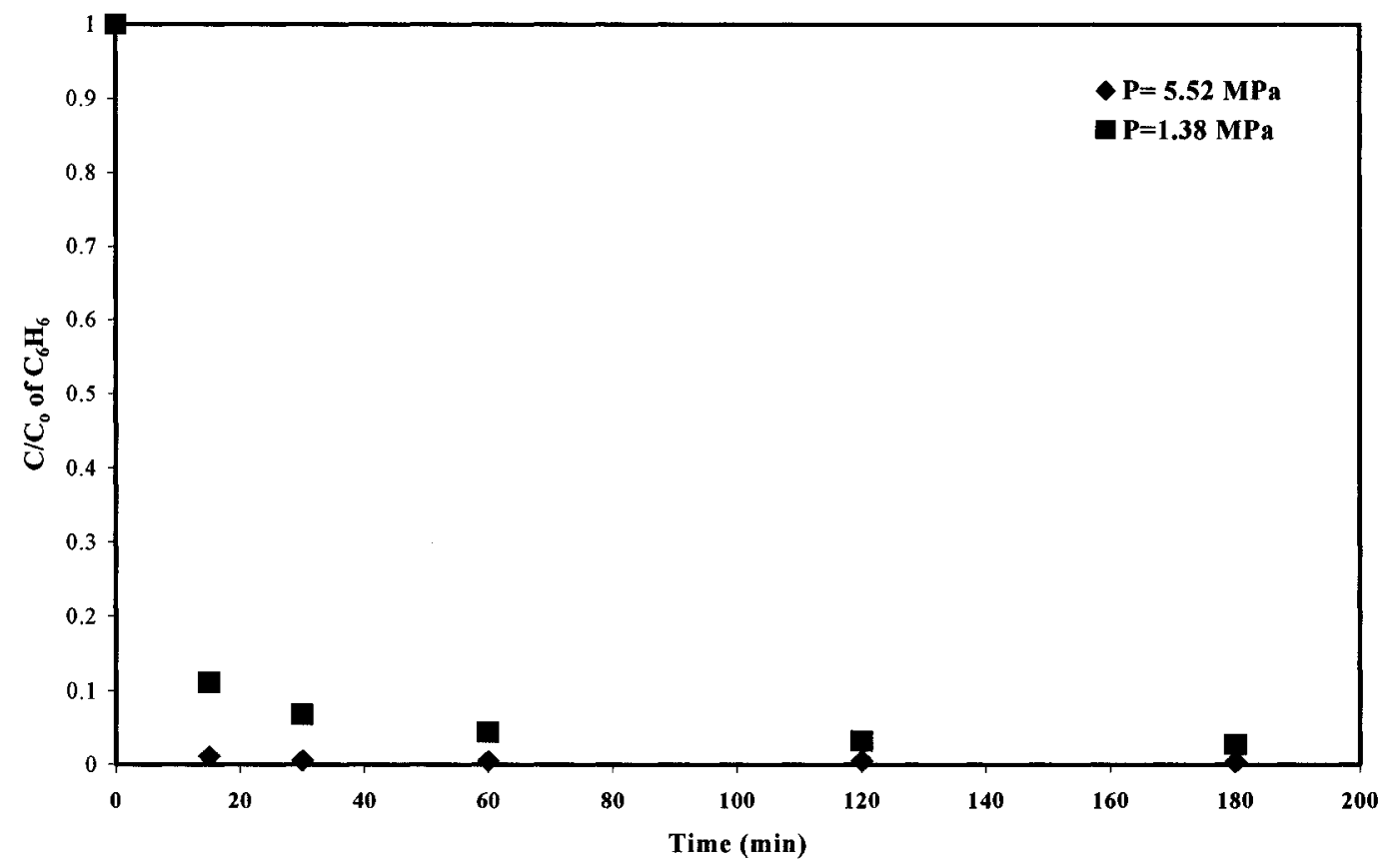

Figure 4.13: Degradation of Benzene at Different Oxygen Pressure, $\mathrm{T}=260^{\circ} \mathrm{C}, \mathrm{pH}=6$.

Furthermore, the effect of the oxygen pressure on the benzene degradation was studied at $260^{\circ} \mathrm{C}$ and $\mathrm{pH} 6$, at which more samples were collected. Figure 4.14 shows that 
at $1.03 \mathrm{MPa}$ the degradation of benzene was slow, and that in the first 2.5 minutes higher degradation was achieved with $2.07 \mathrm{MPa}$ than 1.38 MPa. However, this effect diminished as the time proceeded. Also, comparable results were obtained for both $1.38 \mathrm{MPa}$ and 1.72 MPa. This is attributed to the amount of dissolved oxygen in the liquid phase. More clearly, since at the beginning of the experiment more benzene was present in the solution, more oxygen was needed. However, after the oxidation proceeded less oxygen was needed, which made the results comparable at the later stages. A detailed discussion about the effect of $\mathrm{P}_{\mathrm{O} 2}$ on the dissolved oxygen is discussed in Section 4.4.6.

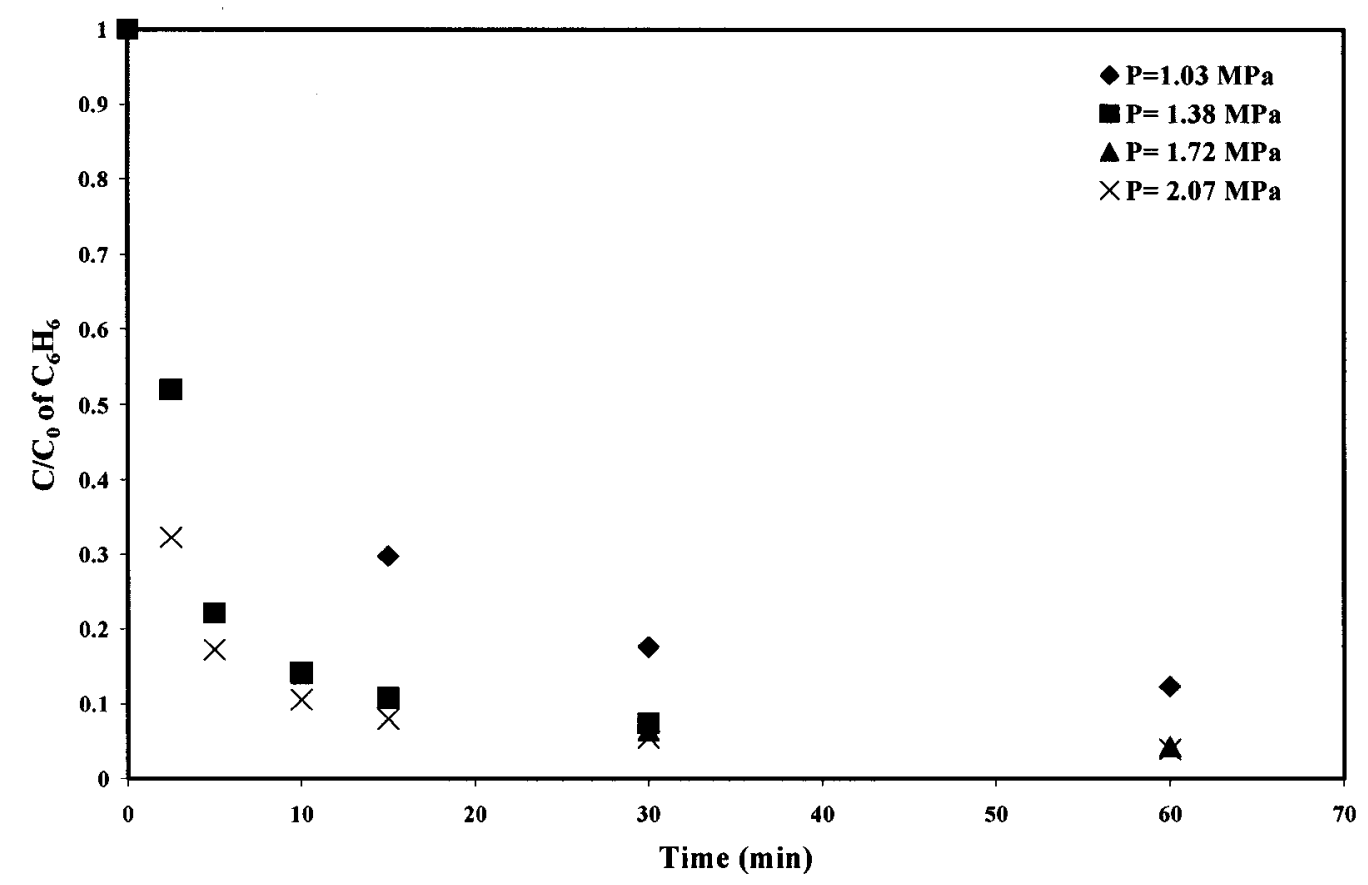

Figure 4.14: Effect of Oxygen Pressure on the Benzene Degradation at $260^{\circ} \mathrm{C}$, $\mathrm{pH}=6$. 


\subsubsection{Effect of Temperature on the Benzene Degradation at $\mathrm{pH} 5$}

As explained in the previous section, the major effect of temperature is in the high range; therefore experiments were done at $\mathrm{pH} 5$ and two temperatures, $220^{\circ} \mathrm{C}$ and $240^{\circ} \mathrm{C}$. As expected, the degradation was faster at $240^{\circ} \mathrm{C}$; however, a slightly higher conversion was achieved after 15 minutes at the lower temperature (Figure 4.15). The main reason for this may be that at the lower temperature more of the carboxylic acids produced during the degradation of benzene stayed in the solution. This keeps the $\mathrm{pH}$ of the solution low hence resulting in higher conversion of benzene.

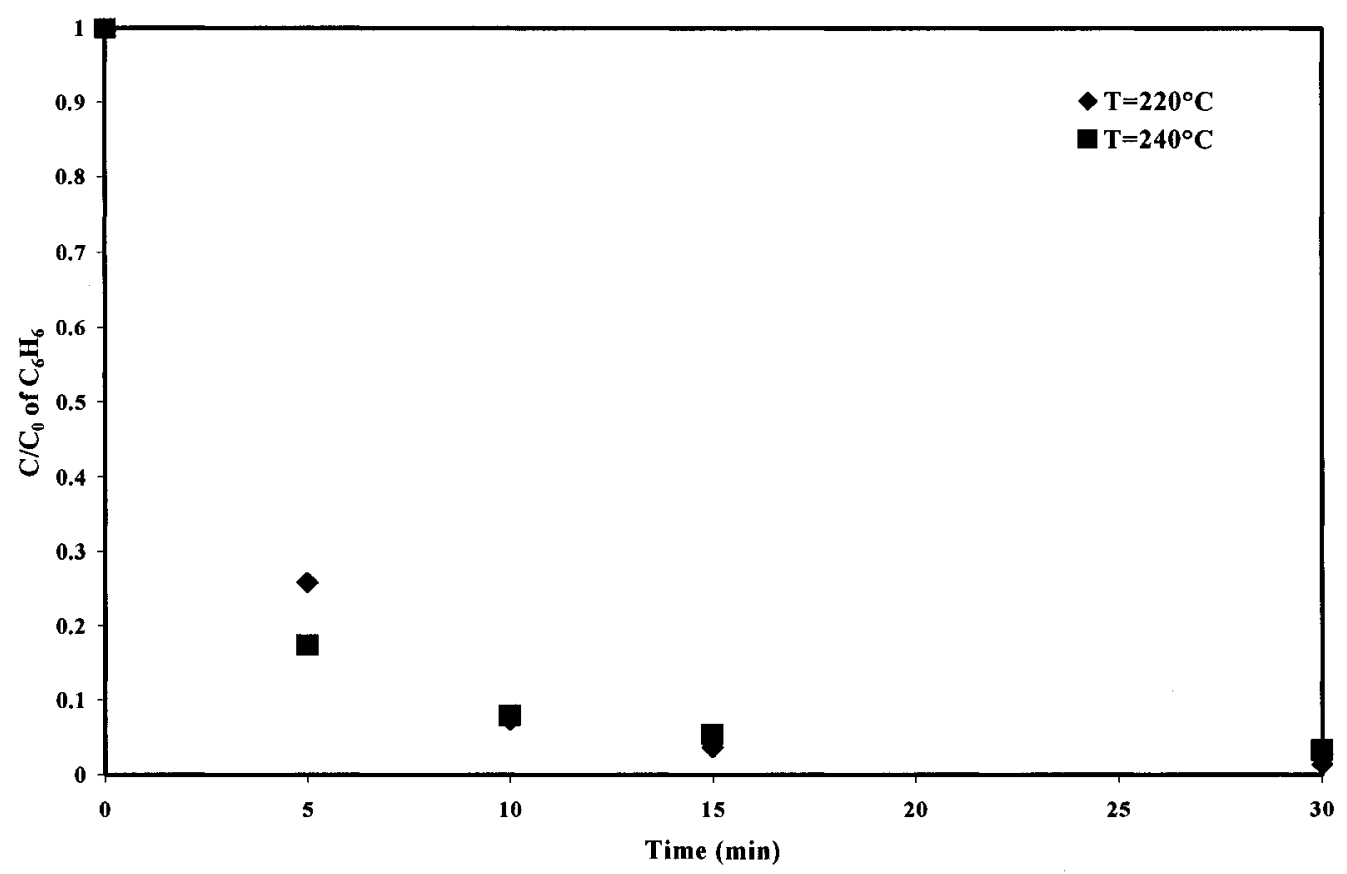

Figure 4.15: Effect of Temperature on the Benzene Degradation at $\mathrm{pH} 5, \mathrm{P}_{\mathrm{O} 2}=1.38 \mathrm{MPa}$. 


\subsubsection{Effect of the Oxygen Pressure on Benzene Degradation at pH 5}

Three different oxygen pressures were chosen $(1.38,1.72$ and $2.07 \mathrm{MPa})$ to study the effect of oxygen pressure on the benzene degradation at $220^{\circ} \mathrm{C}$ and $\mathrm{pH}$. Figure 4.16 shows the effect of oxygen pressure on the benzene degradation. It is apparent that the higher the oxygen pressure the higher the benzene degradation, especially at the beginning of the oxidation. This effect diminished as the oxidation proceeded. More details about the effect of $\mathrm{P}_{\mathrm{O} 2}$ on the benzene degradation will be shown in Section 4.4.6

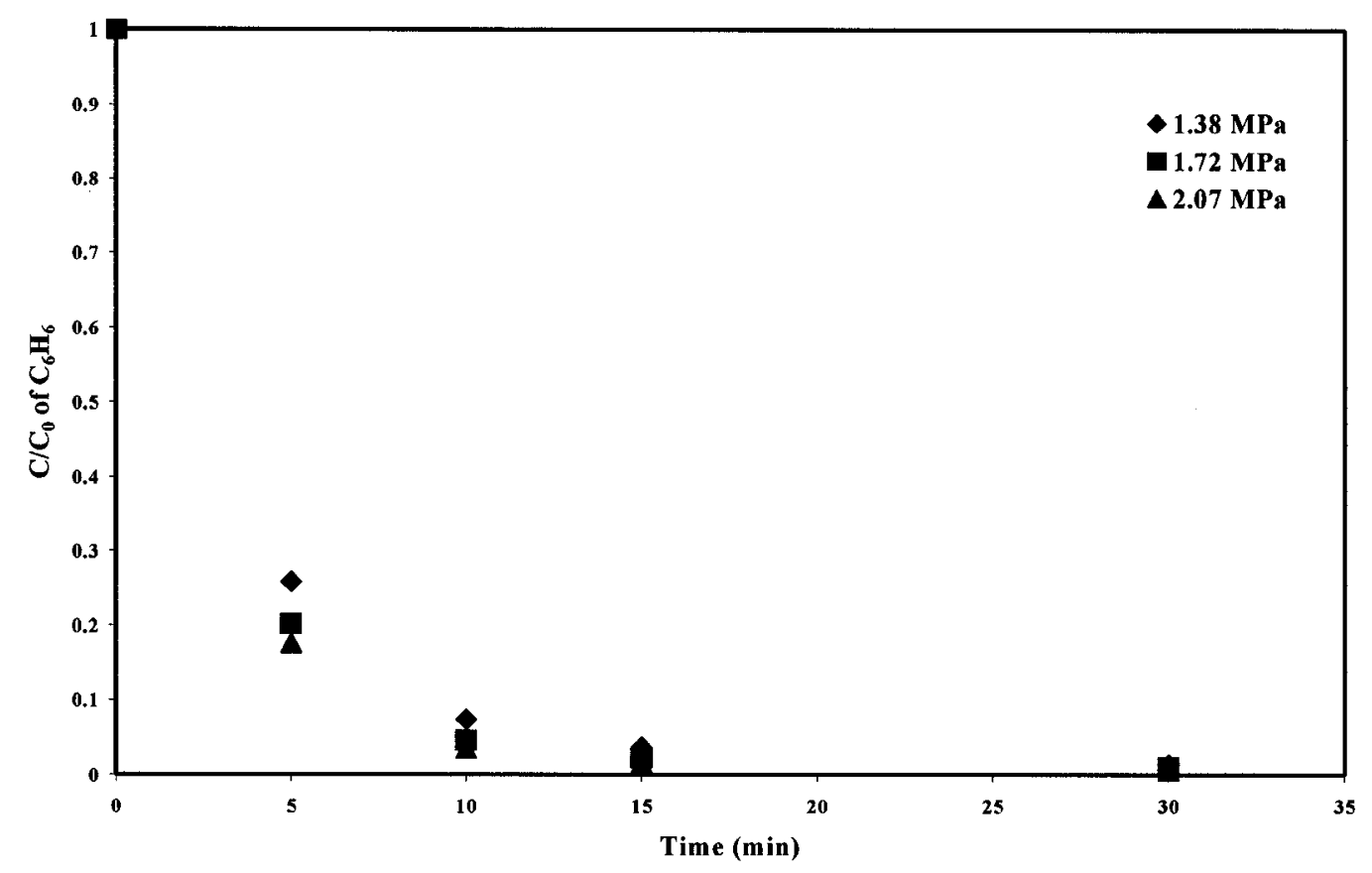

Figure 4.16: Effect of Oxygen Pressure on the Benzene Degradation at $\mathrm{pH} 5$. 


\subsubsection{Effect of Temperature on Benzene Degradation at pH 4}

The effect of temperature on the benzene degradation has been studied at different temperatures and pressures at $\mathrm{pH} 4$. Figures $4.17,4.18$ and 4.19 show the effect of temperature on the degradation of benzene at $\mathrm{pH} 4$ and at oxygen pressures of $1.03,1.38$ 1.72 MPa, respectively. It can be seen that at lowest pressure almost same results have been obtained for the $240^{\circ} \mathrm{C}$ and $260^{\circ} \mathrm{C}$, especially in the first 5 minutes. In this period the oxidation at those two temperatures was faster than that of $220^{\circ} \mathrm{C}$. After 10 minutes of oxidation, the degradation was better at $220^{\circ} \mathrm{C}$ than those at $240^{\circ} \mathrm{C}$ and $260^{\circ} \mathrm{C}$. At 1.38 $\mathrm{MPa}$, higher benzene degradation has been achieved at $260^{\circ} \mathrm{C}$ at the beginning of the experiment. After 5 minutes of oxidation the results became comparable for all three temperatures and later, the higher benzene conversion has been achieved for the lowest temperature. When the pressure was increased to $1.72 \mathrm{MPa}$ the similar pattern was observed. One possible reason for this is that at the beginning of the oxidation, the higher temperature resulted in higher degradation, hence more acids were produced. This lowered the $\mathrm{pH}$ of the reaction medium (Section 4.4.7). At higher temperatures (i.e. $260^{\circ} \mathrm{C}$ ), these acids were oxidized faster (see Chapter 5), and because of that the $\mathrm{pH}$ of the medium increased. However, at lower temperature, produced acids were more stable which kept the $\mathrm{pH}$ lower than that achieved at higher temperature, thus resulting in higher degradation. 


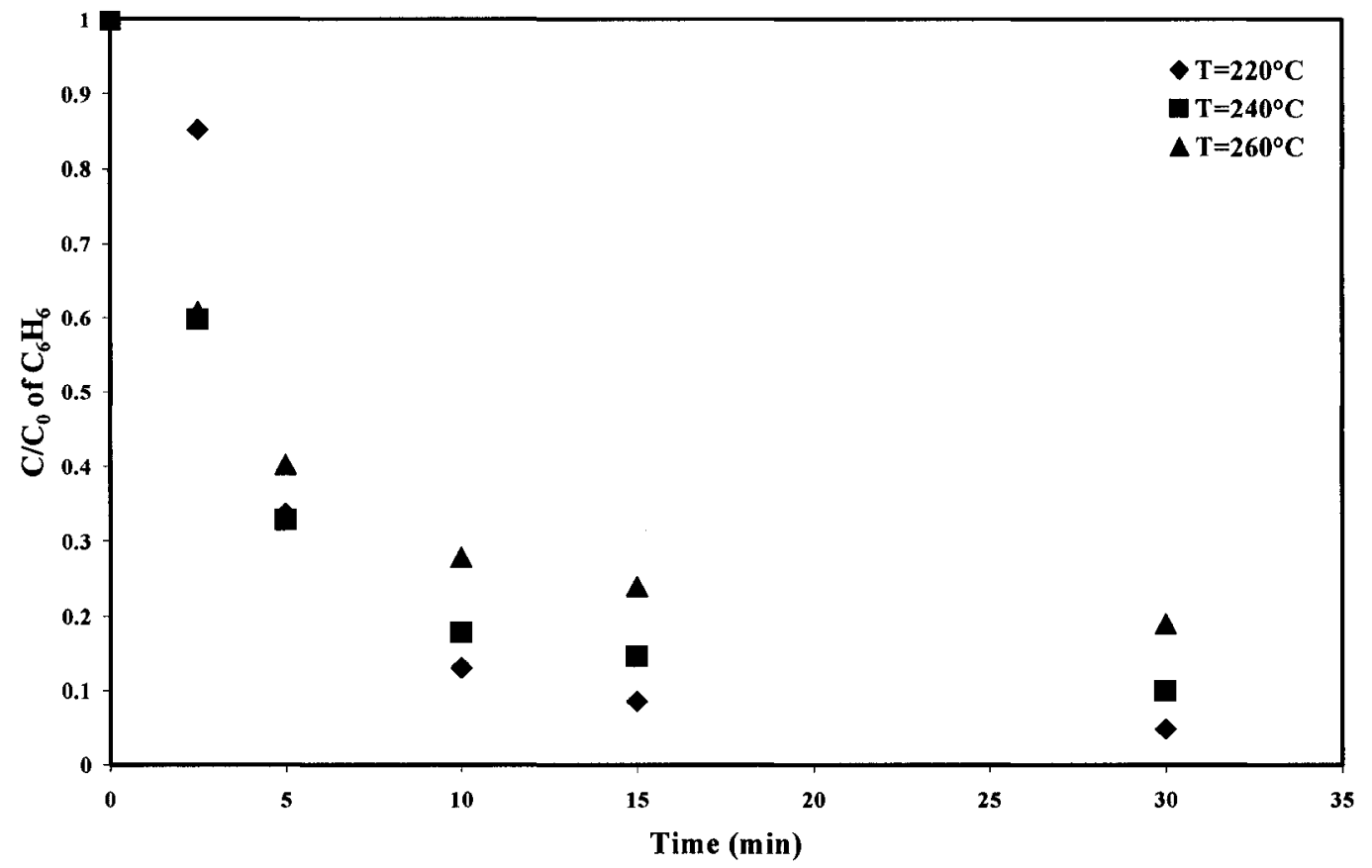

Figure 4.17: Effect of Temperature on the Benzene Degradation at $1.03 \mathrm{MPa}, \mathrm{pH}=4$.

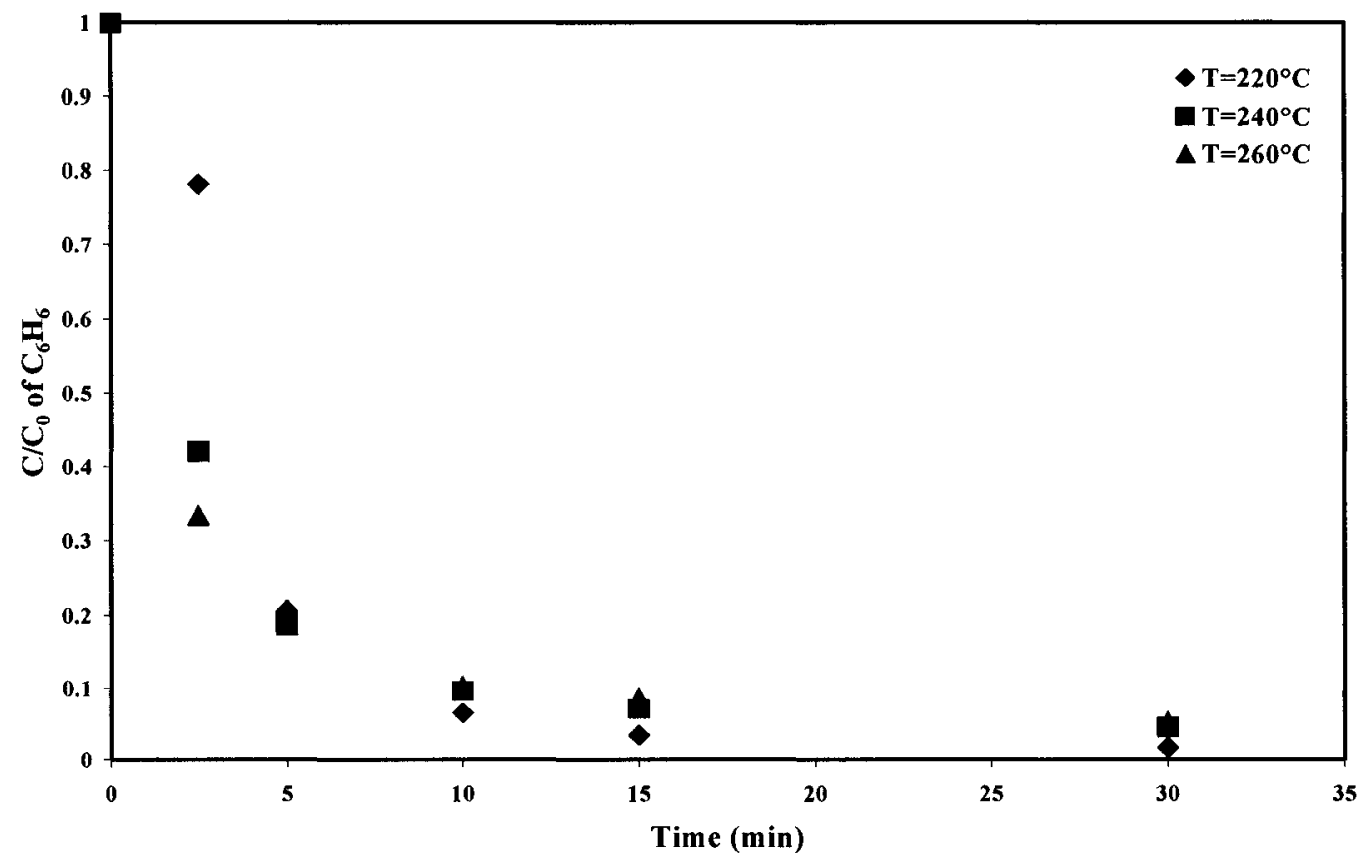

Figure 4.18: Effect of Temperature on the Benzene Degradation at $1.38 \mathrm{MPa}, \mathrm{pH}=4$. 


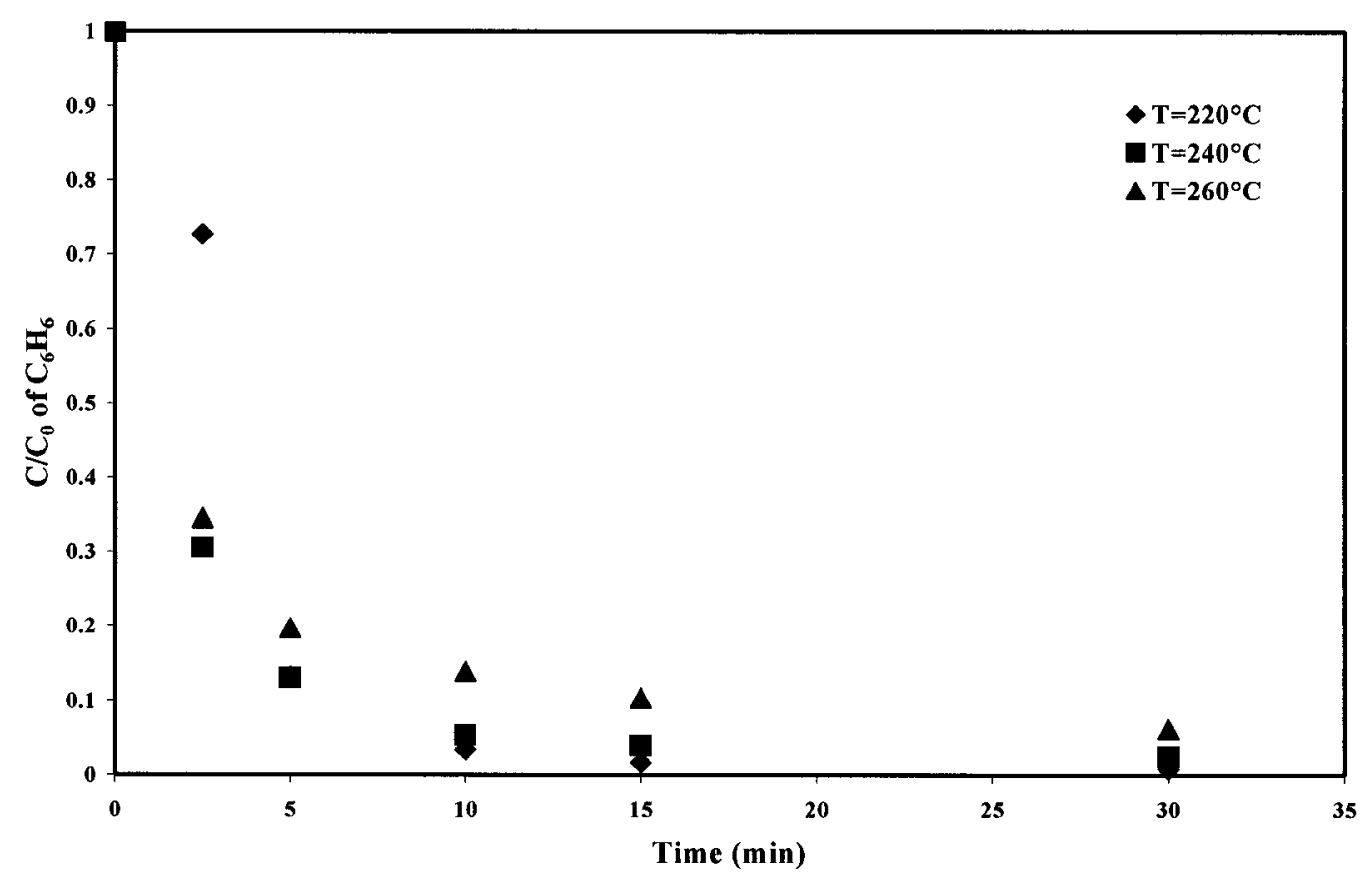

Figure 4.19: Effect of Temperature on the Benzene Degradation at $1.72 \mathrm{MPa}, \mathrm{pH}=4$.

\subsubsection{Effect of the Oxygen Pressure on the Benzene Degradation at pH 4}

The effect of oxygen partial pressure on the benzene degradation was further studied at 220,240 and $260^{\circ} \mathrm{C}$, respectively and at $\mathrm{pH} 4$. At $220^{\circ} \mathrm{C}$ the degradation was studied at the range of $0.69 \mathrm{MPa}$ to $1.72 \mathrm{MPa}$. Figure 4.20 demonstrates that the oxidation started slowly within the first 2.5 minutes followed by a fast oxidation step, during which most of the benzene was degraded. After that, the oxidation slowed down. It is apparent that the degradation in the first 2.5 minutes, in which the oxidation process was slow, was almost comparable for $0.69,0.86$ and $1.03 \mathrm{MPa}$, while it was slightly faster for both 1.38 and 1.72 MPa, respectively. This may be due to the accumulation of radicals at this low temperature and low $\mathrm{P}_{\mathrm{O} 2}$. After 5 minutes of oxidation, it was clear that the degradation of benzene increased with the increase of the oxygen partial pressure. At higher 
temperatures, the effect of the oxygen pressure on the benzene degradation was more pronounced as it appears in Figures 4.21 and 4.22 at 240 and $260^{\circ} \mathrm{C}$, respectively. While only $40 \%$ degradation was achieved at $240^{\circ} \mathrm{C}$ after 2.5 minutes with $1.03 \mathrm{MPa}, 58 \%$ and $70 \%$ have been achieved at 1.38 and $1.72 \mathrm{MPa}$, respectively. It is apparent that the oxygen partial pressure has a significant effect on the benzene degradation. This is attributed to the amount of the oxygen dissolved in the liquid phase. Table 4.1 shows the solubility of oxygen (Caq) in the water at different temperatures. The detailed calculation can be found in Appendix B.

Table 4.1: Solubility of Oxygen in Water at Different Temperatures.

\begin{tabular}{||c|c|c|c|}
\cline { 2 - 4 } \multicolumn{1}{c|}{} & \multicolumn{3}{c|}{ Caq (mol/kg water) } \\
\hline $\mathrm{P}_{\mathrm{O} 2}(\mathrm{MPa})$ & $\mathrm{T}=220^{\circ} \mathrm{C}$ & $\mathrm{T}=240^{\circ} \mathrm{C}$ & $\mathrm{T}=260^{\circ} \mathrm{C}$ \\
\hline 0.69 & 0.012 & & \\
\hline 0.86 & 0.014 & & 0.027 \\
\hline 1.03 & 0.017 & 0.021 & 0.035 \\
\hline 1.38 & 0.023 & 0.028 & 0.044 \\
\hline 1.72 & 0.029 & 0.035 & \\
\hline
\end{tabular}




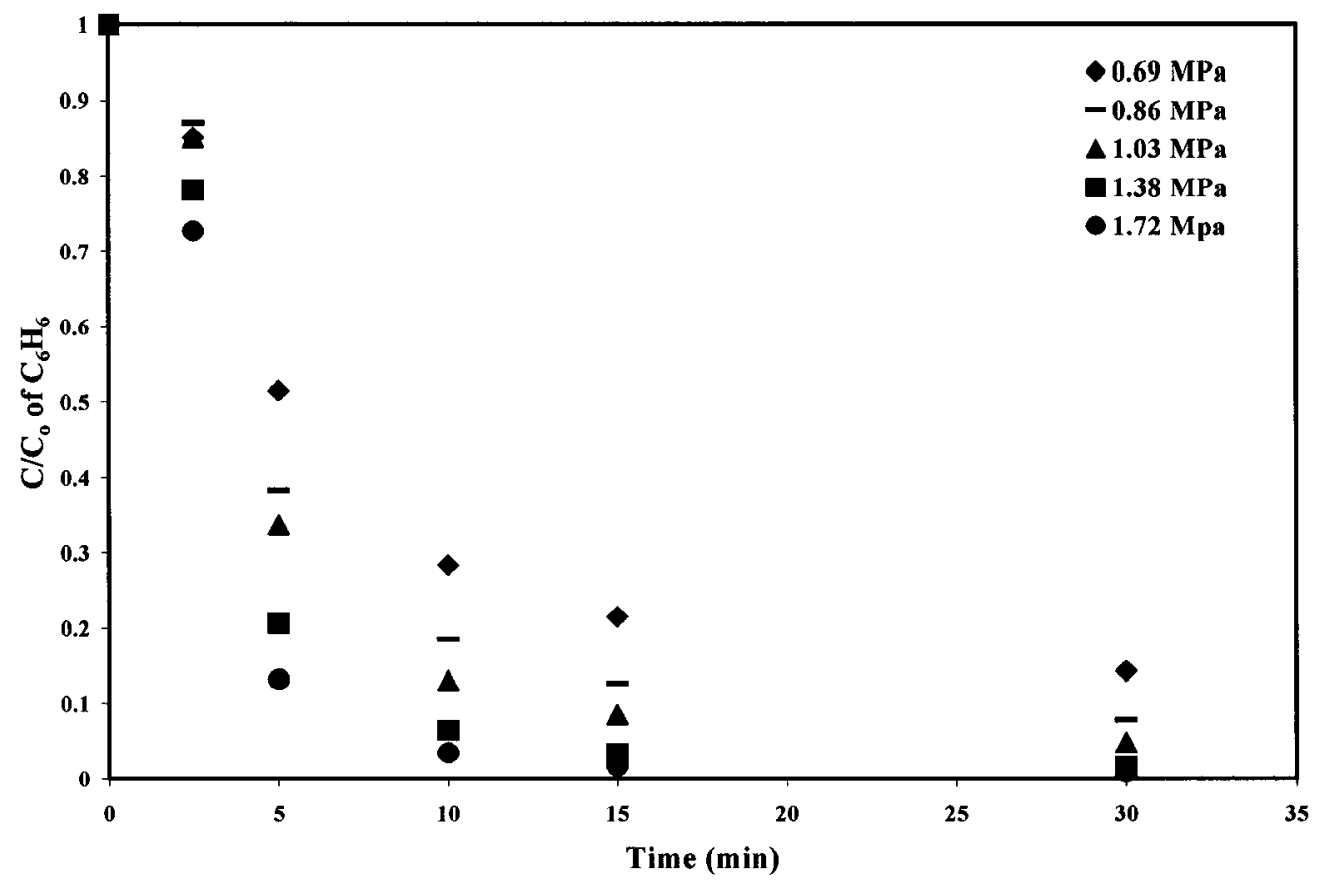

Figure 4.20: Effect of Oxygen Pressure on the Benzene Degradation at $220^{\circ} \mathrm{C}, \mathrm{pH} 4$.

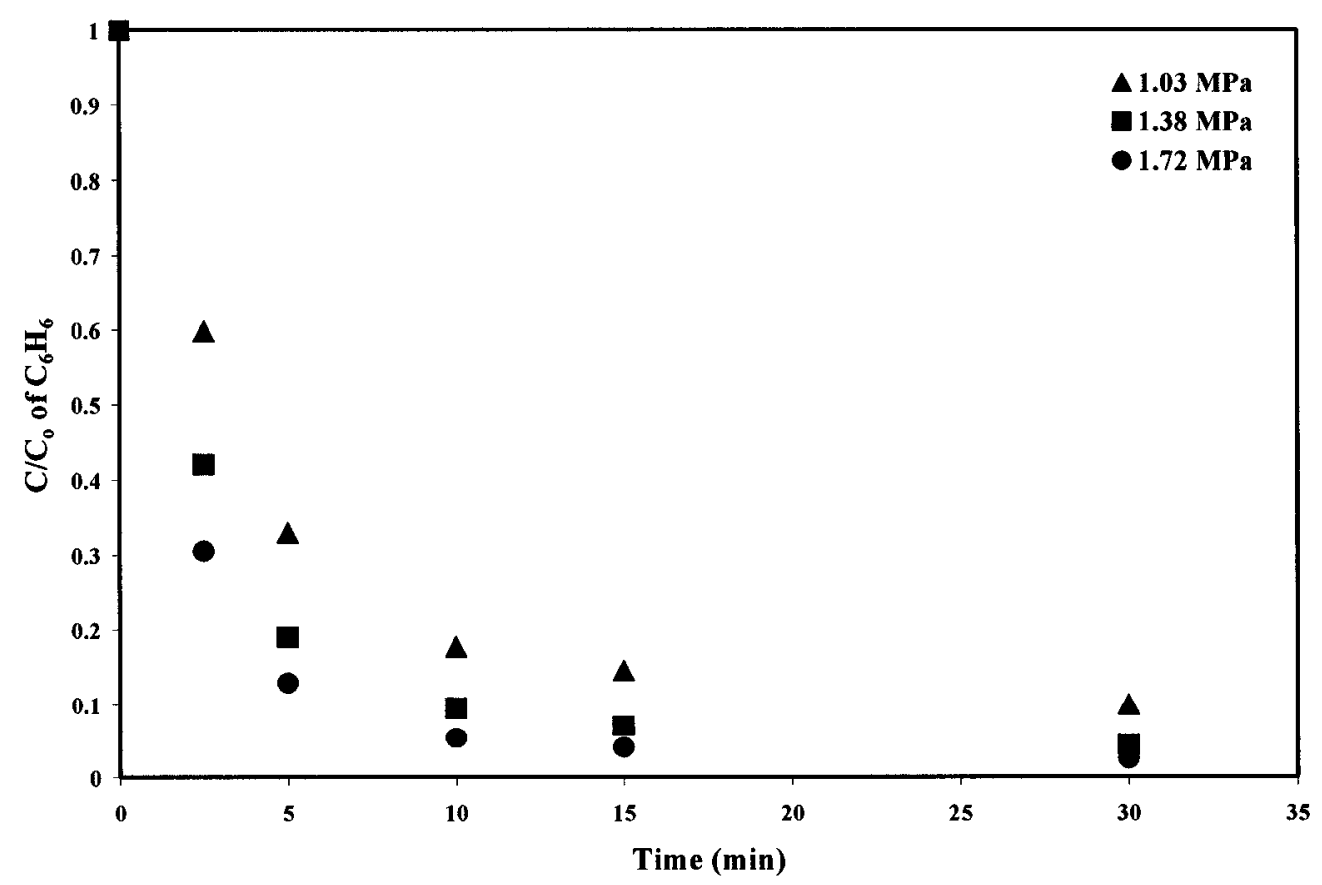

Figure 4.21: Effect of Oxygen Pressure on the Benzene Degradation at $240^{\circ} \mathrm{C}, \mathrm{pH} 4$. 


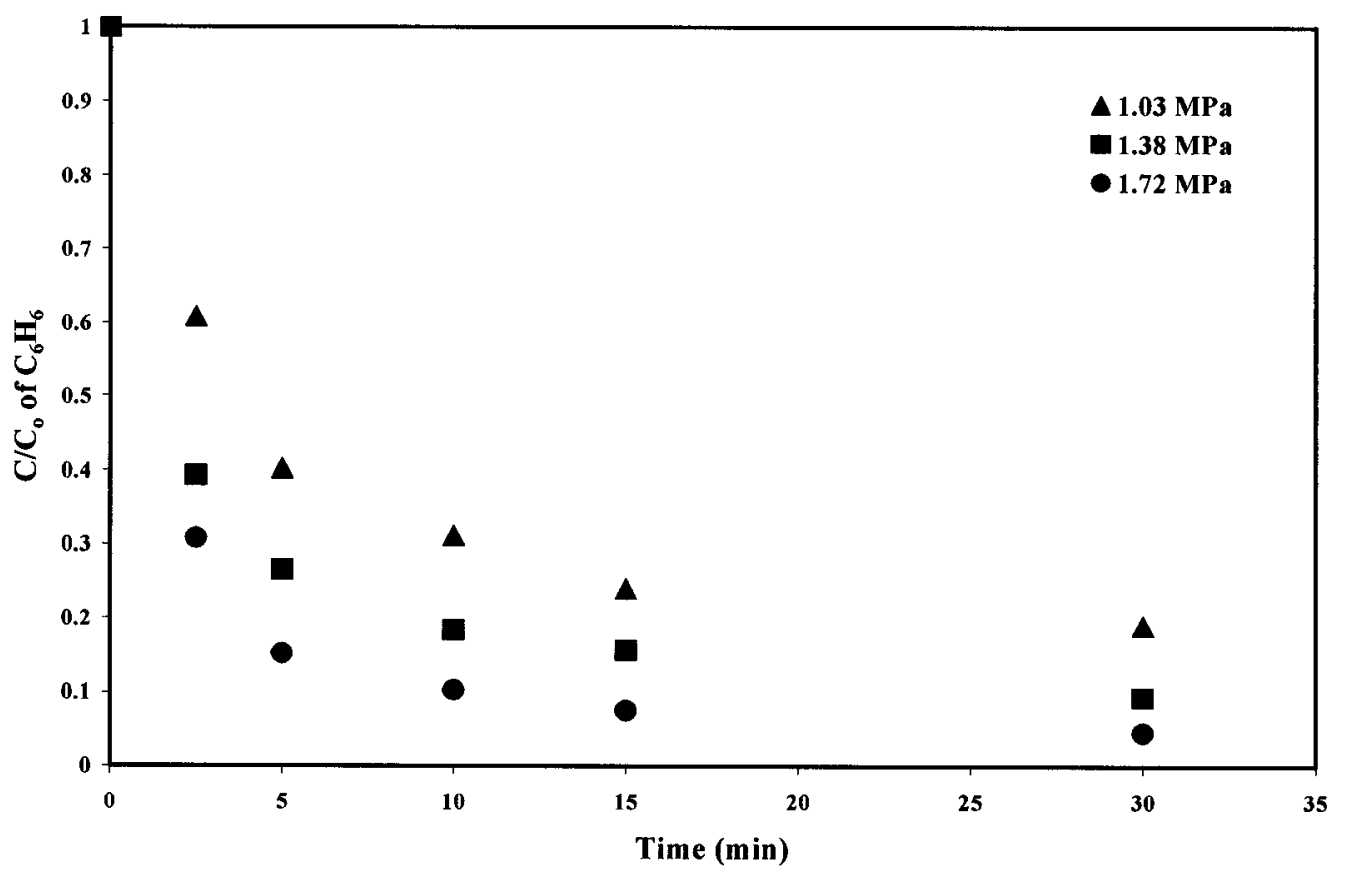

Figure 4.22: Effect of Oxygen Pressure on the Benzene Degradation at $260^{\circ} \mathrm{C}, \mathrm{pH} 4$.

\subsubsection{The pH Fluctuation during the Experiments}

As was mentioned before, during each experiment the $\mathrm{pH}$ of the solution fluctuated. At the beginning of the experiment, as benzene started to oxidize organic acids were produced and the $\mathrm{pH}$ of the solution decreased. As the experiment proceeded most of the produced organic acids oxidized, thus increasing the $\mathrm{pH}$ of the solution. As shown in Figure 4.23 , the $\mathrm{pH}$ decreased faster at 240 and 260 than $220^{\circ} \mathrm{C}$. Also, as will be seen in chapter 5, at higher temperatures lower amounts of acids were produced and degraded faster than at the lower temperature. This is reflected on the $\mathrm{pH}$ value with its initial steep decrease followed by the subsequent increase. 


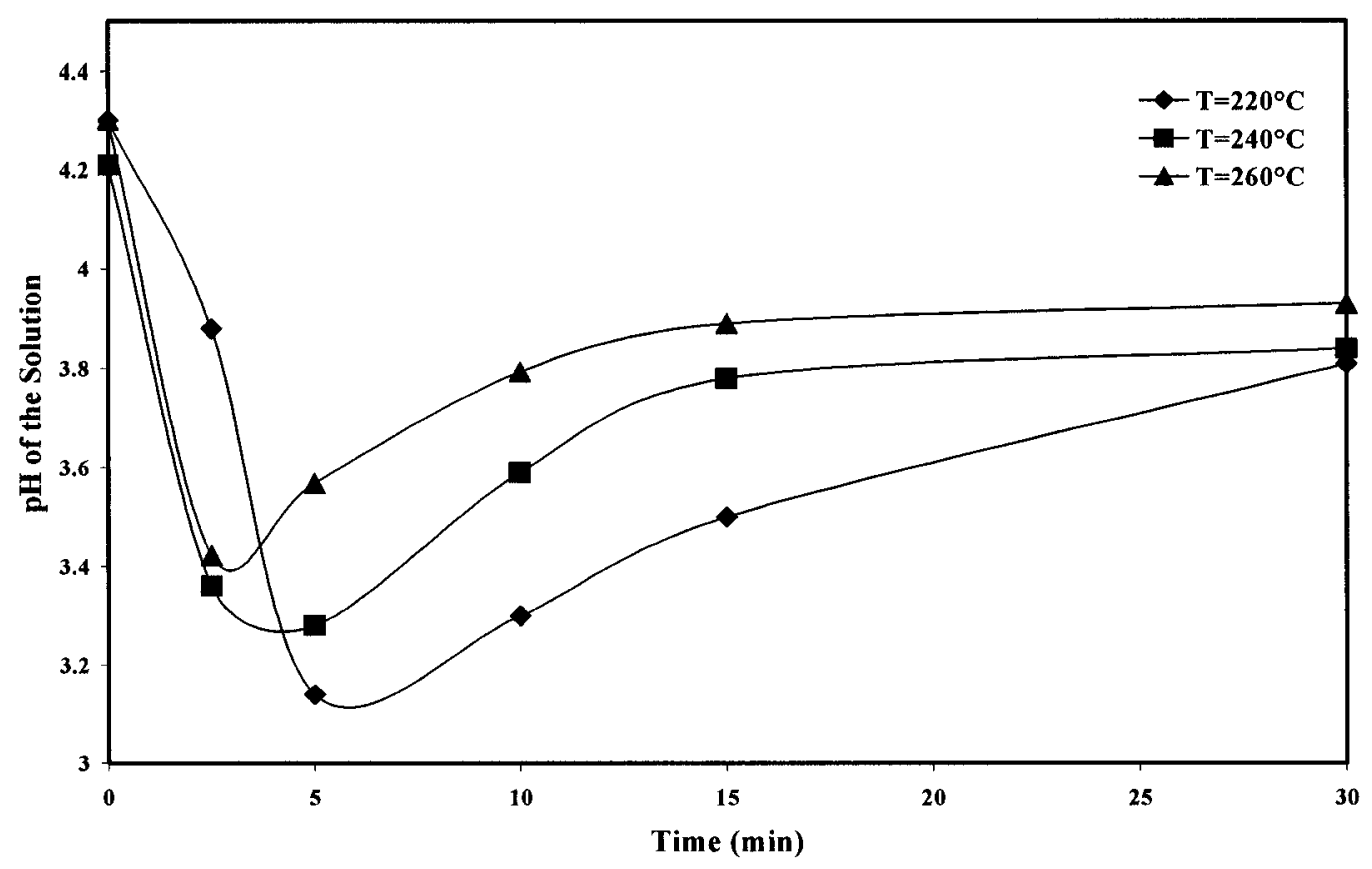

Figure 4.23: Change of $\mathrm{pH}$ with Time during Experiment, $\mathrm{P}_{\mathrm{O} 2}=1.38 \mathrm{MPa}$, Initial Benzene Concentration $=5.63 \mathrm{mmol} / \mathrm{L}$.

\subsubsection{Effect of Acidification Methods on the Degradation of Benzene}

Nitric acid was commonly used to lower the $\mathrm{pH}$ of the reaction medium. However, sulfuric acid was also tried. From Figure 4.24, it is obvious that with the sulfuric acid also a good degradation was achieved at $220^{\circ} \mathrm{C}$ and $1.38 \mathrm{MPa}$. The initial $\mathrm{pH}$ of this experiment was 4 . Furthermore, to determine whether the type of the additive has an effect on the quality of the oxidation, two experiments have been repeated at the same $\mathrm{pH}$ with two different additives, nitric and acetic acids. These experiments have been done at $240^{\circ} \mathrm{C}$ and oxygen pressure of $1.38 \mathrm{MPa}$. It can be seen from Figure 4.25 that the results were comparable, which suggests that the oxidation is independent on the type of acid, as long as the given $\mathrm{pH}$ is reached. 


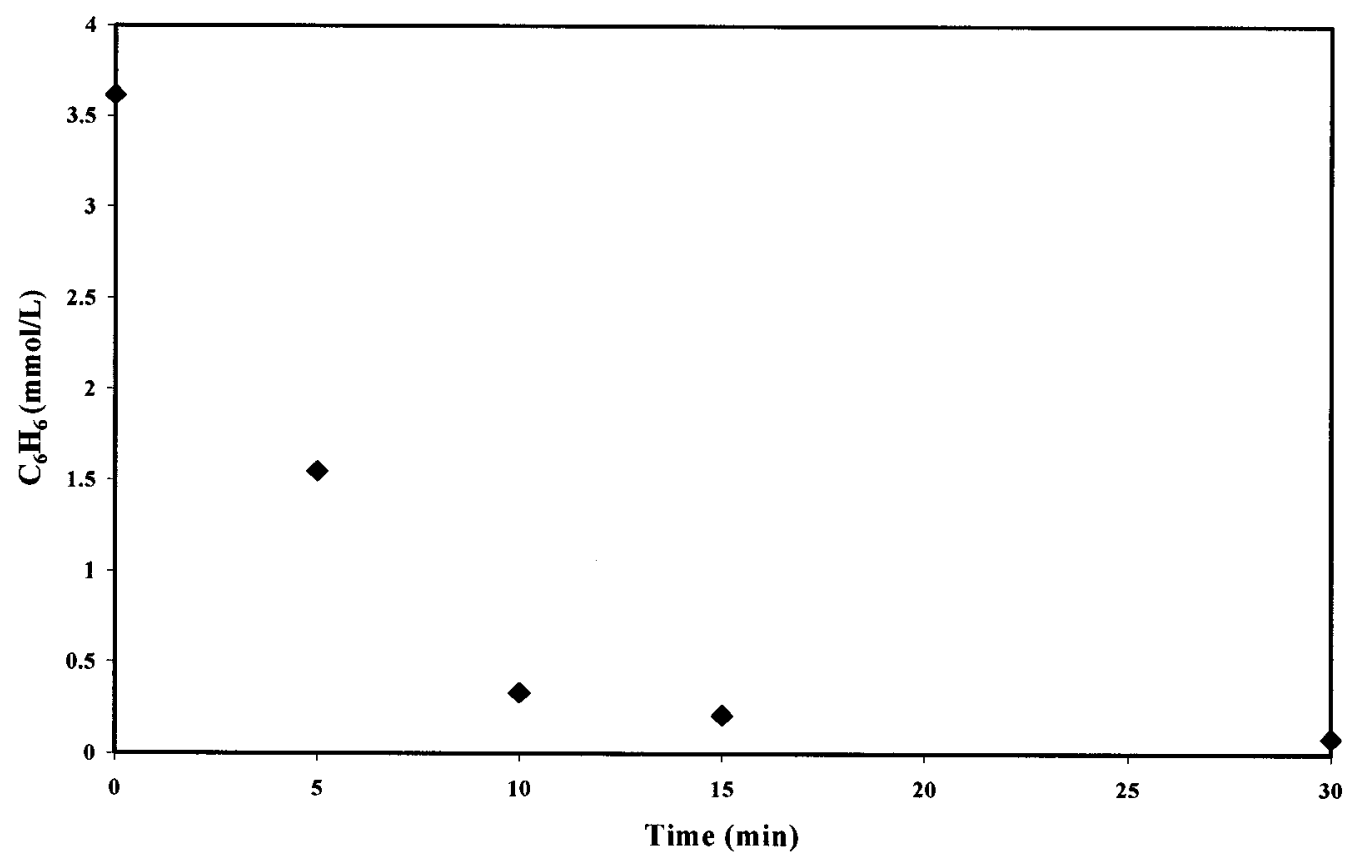

Figure 4.24: Degradation of Benzene with Sulfuric Acid at $220^{\circ} \mathrm{C}, \mathrm{P}_{\mathrm{O} 2}=1.38 \mathrm{MPa}, \mathrm{pH}=4$.

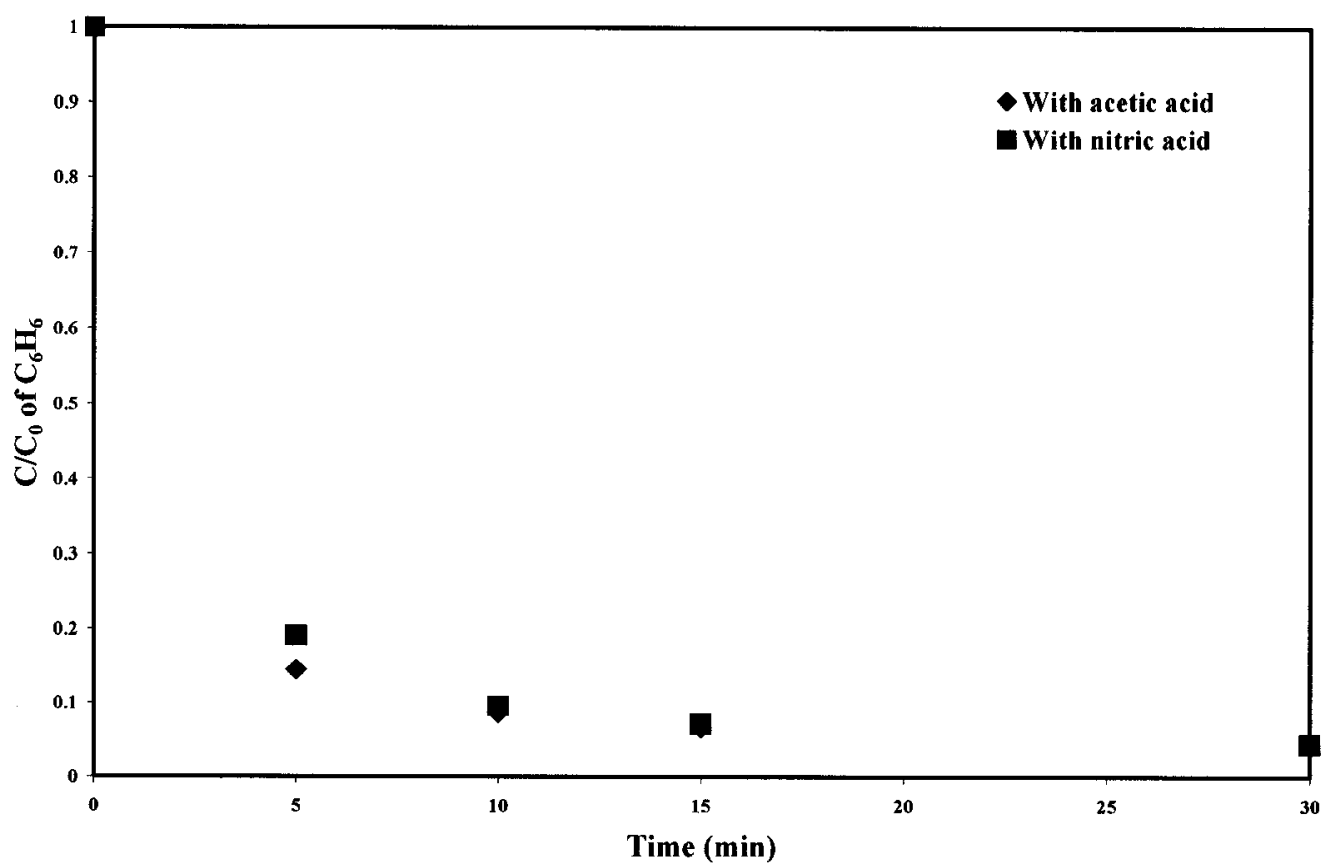

Figure 4.25: Degradation of Benzene at $240^{\circ} \mathrm{C}, \mathrm{P}_{\mathrm{O} 2}=1.38 \mathrm{MPa}, \mathrm{pH}=4$. 


\subsection{Effect of Initial Benzene Concentration on its Degradation}

In the results presented thus far, the initial benzene concentration was $5.63 \mathrm{mmol} / \mathrm{L}$. In order to determine the effect of concentration, two experiments were done with initial benzene concentration of $11.25 \mathrm{mmol} / \mathrm{L}$ and $16.88 \mathrm{mmol} / \mathrm{L}$. Experiments carried out in the high temperature region, i.e. 220,240 and $260^{\circ} \mathrm{C}$ and at $\mathrm{pH} 6$ and 4 . There was always the excess amount of oxygen in these experiments.

Figures 4.26 and 4.27 show the benzene degradation at $260^{\circ} \mathrm{C}$ and $\mathrm{pH} 6$. In both experiments, $95 \%$ degradation of benzene was achieved. In both of these experiments the amount of acids that have been produced was higher than what was produced with the lower initial benzene concentration, as expected, and that lowered the $\mathrm{pH}$ to less than 3 . The effect of initial benzene concentrations was further studied at $\mathrm{pH} 4$. Two experiments were done with initial benzene concentration of $11.25 \mathrm{mmol} / \mathrm{L}$. These experiments were conducted at both 220 and $240^{\circ} \mathrm{C}$, and the oxygen pressure of $2.76 \mathrm{MPa}$ (Figure 4.28). It can be seen that at the first 2.5 minutes the degradation was much faster at $240^{\circ} \mathrm{C}$ and after that the results were comparable.

Figure 4.29 shows the $\mathrm{pH}$ profile of the solution when the initial benzene concentration was $11.25 \mathrm{mmol} / \mathrm{L}$ at $220^{\circ} \mathrm{C}$ and an initial oxygen pressure of $2.76 \mathrm{MPa}$. It is apparent that the $\mathrm{pH}$ reached below 3 after 5 minutes of oxidation. One of the important issues in these experiments was the safety concern raised from the high concentration of the organic acid produced due to the high initial benzene concentration when the $\mathrm{pH}$ of the solution dropped below 3. This low $\mathrm{pH}$ in combination with the high temperature and pressure may corrode the reactor walls thus weakening its structure. 
Because of that, such experiments which resulted in $\mathrm{pH}$ lower than 3 could not be repeated often.

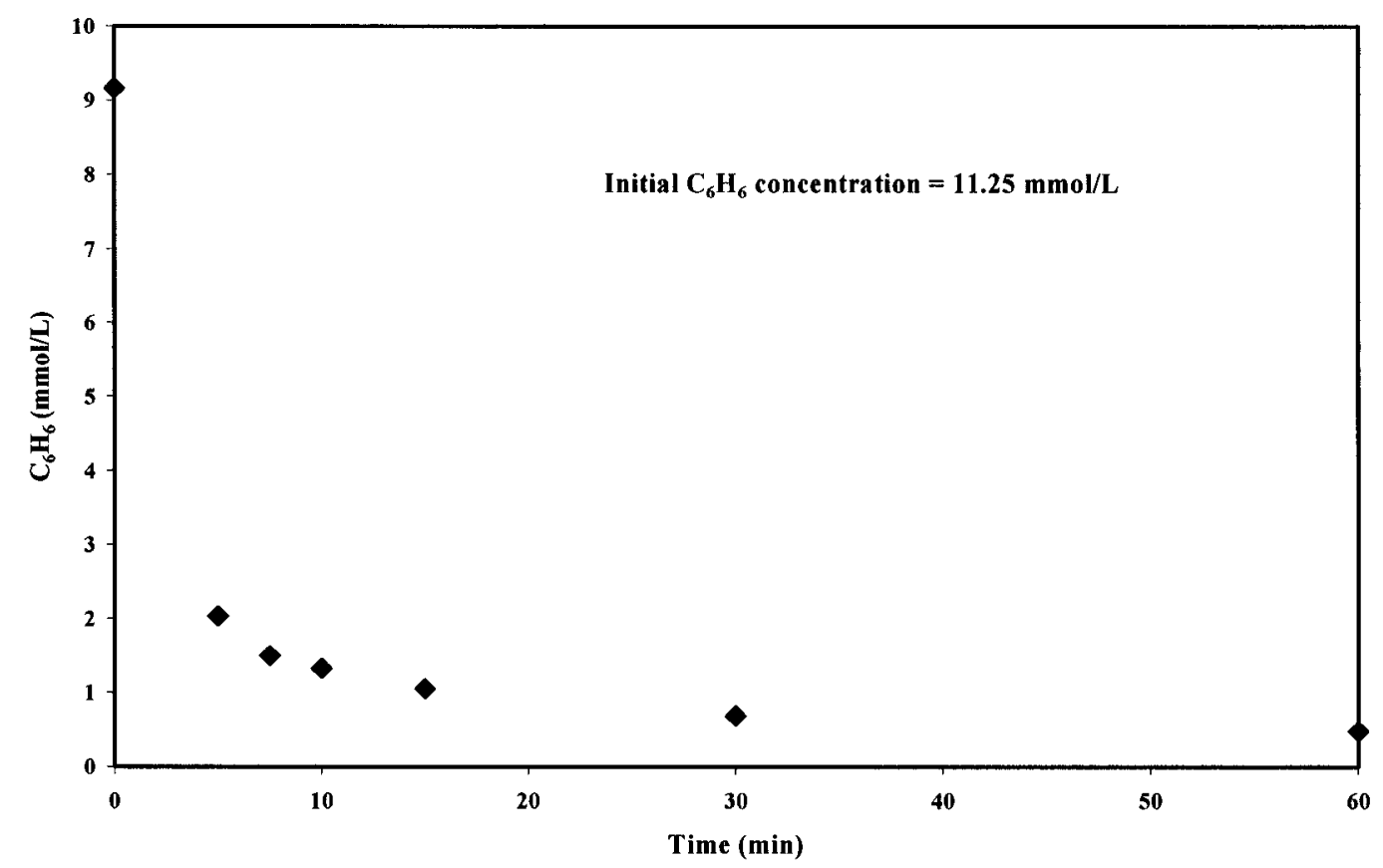

Figure 4.26: Degradation of Benzene at $260^{\circ} \mathrm{C}, \mathrm{P}_{\mathrm{O} 2}=2.07 \mathrm{MPa}, \mathrm{pH}=6$.

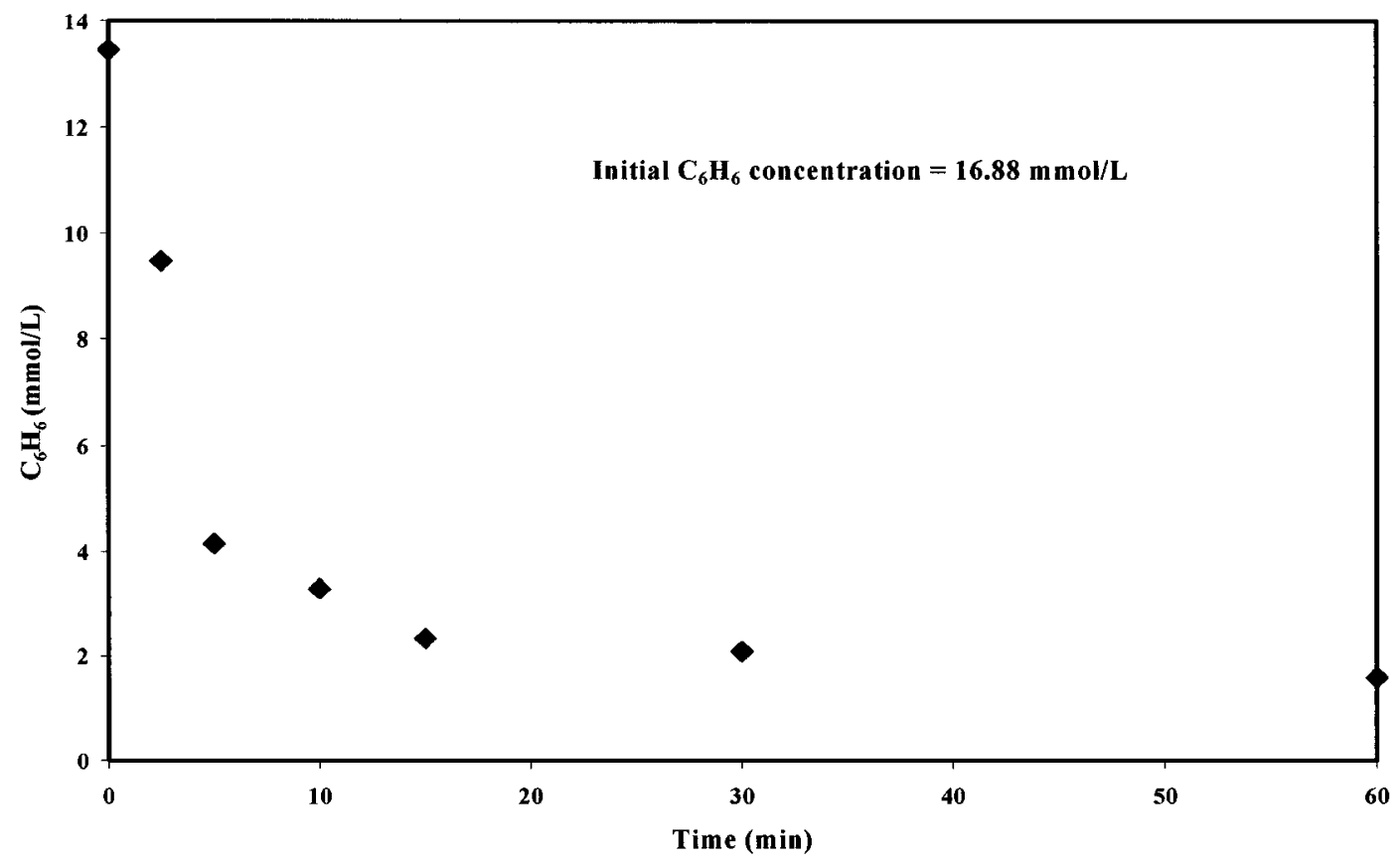

Figure 4.27: Degradation of Benzene at $260^{\circ} \mathrm{C}, \mathrm{P}_{\mathrm{O} 2}=2.07 \mathrm{MPa}, \mathrm{pH}=6$. 


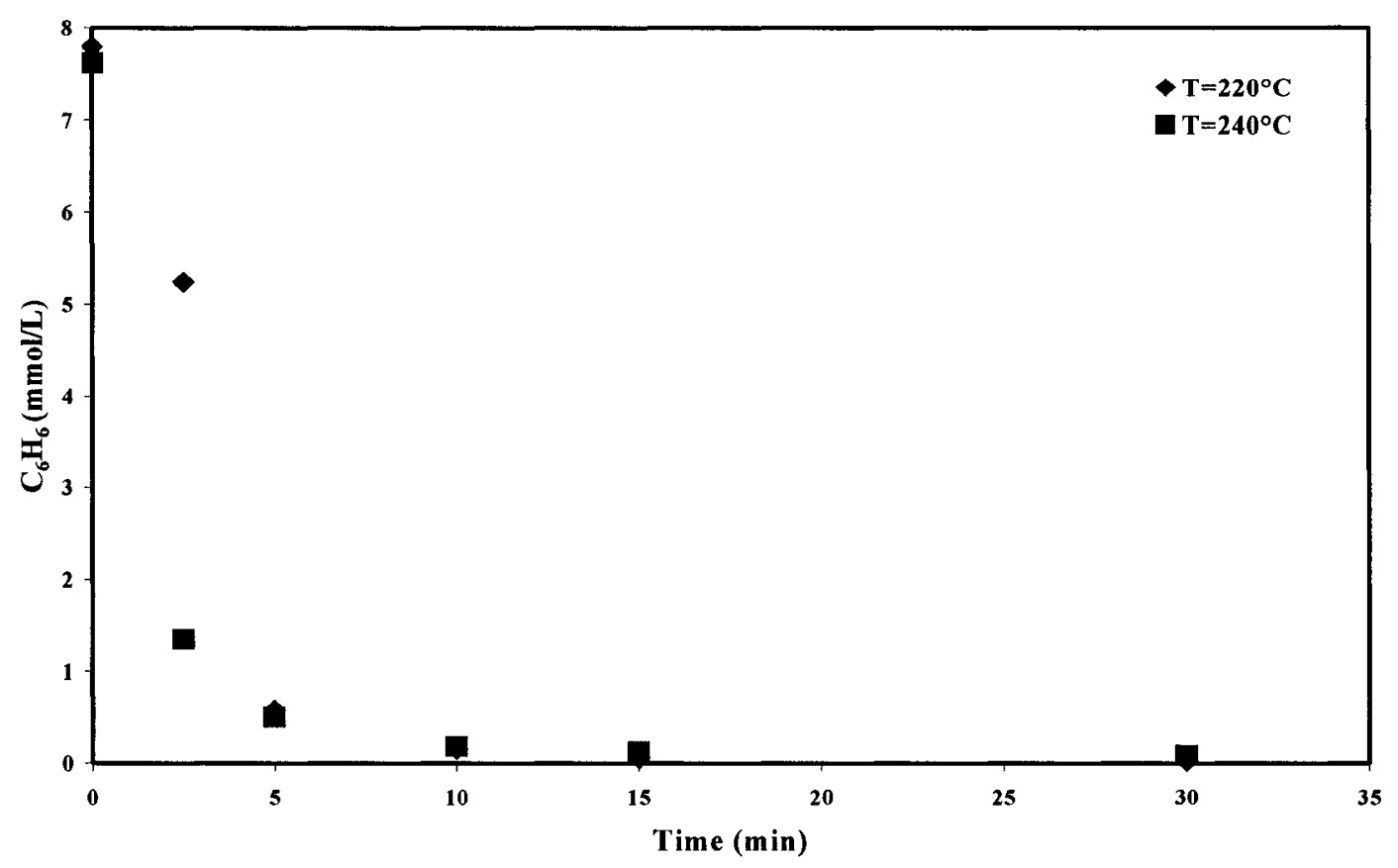

Figure 4.28: Effect of Temperature on Benzene Degradation, $\mathrm{P}_{\mathrm{O} 2}=2.76 \mathrm{MPa}, \mathrm{pH}=4$. Initial Benzene Concentration of $11.25 \mathrm{mmol} / \mathrm{L}$.

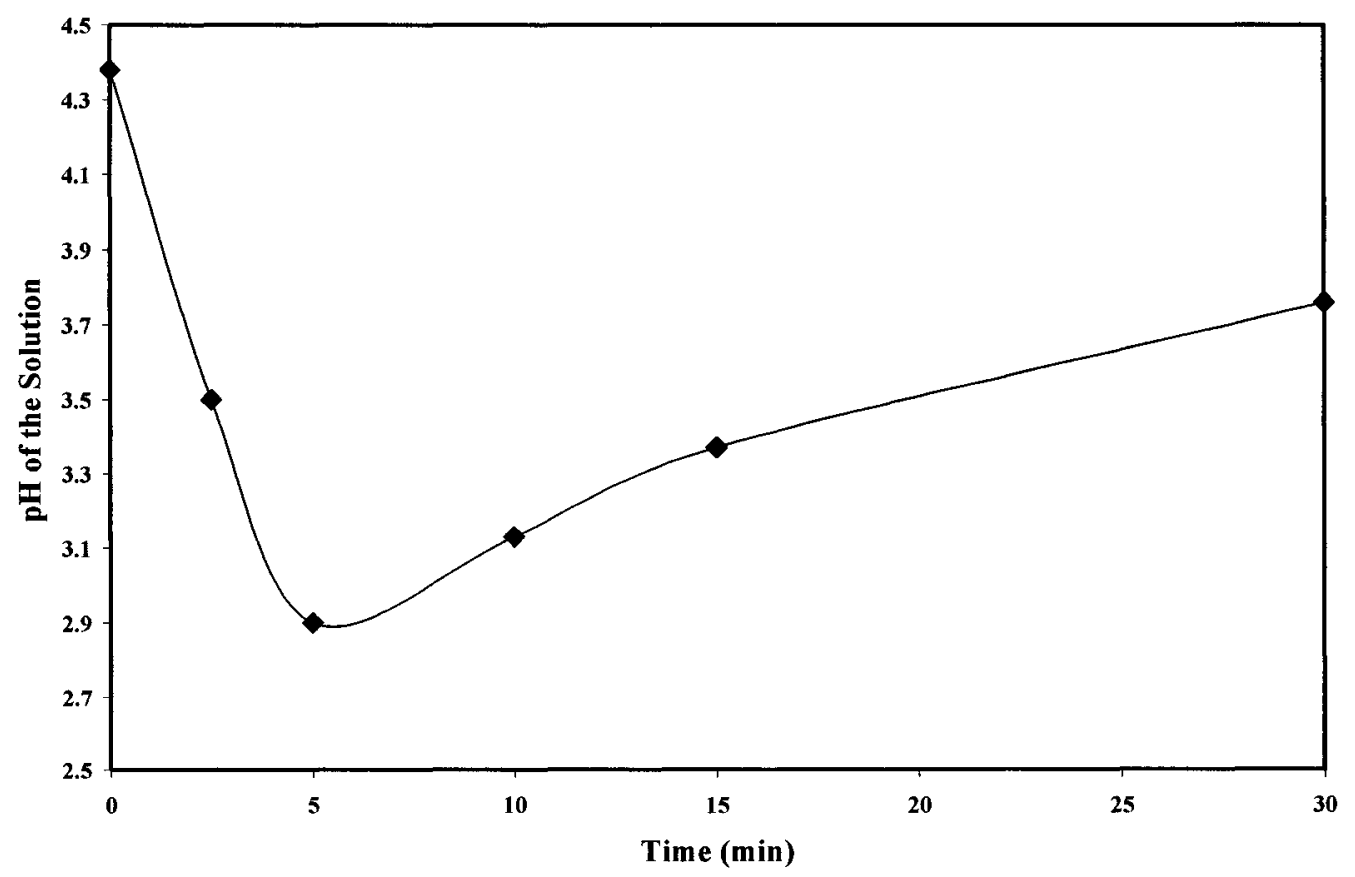

Figure 4.29: Change of $\mathrm{pH}$ with Time during Experiment, $\mathrm{T}=220^{\circ} \mathrm{C} \mathrm{P}_{\mathrm{O} 2}=2.76 \mathrm{MPa}$. Initial Benzene Concentration $=11.25 \mathrm{mmol} / \mathrm{L}$. 


\subsection{Kinetic Modeling}

The kinetics of benzene oxidation was studied at temperatures between $220-260^{\circ} \mathrm{C}$ with oxygen pressures from $0.69 \mathrm{MPa}$ to $1.72 \mathrm{MPa}$, and at initial $\mathrm{pH}$ of 4 . These conditions were chosen because they gave the best degradation results. Because of the experimental set-up limitation, the number of the samples collected during the experiments was limited especially at the beginning of the experiment when the oxidation was very fast. It has affected the quality of the model. Figures $4.30-4.34$ show the results that were obtained at $220^{\circ} \mathrm{C}$ at different oxygen pressures. The oxidation reaction can be represented by two first order reaction kinetics, corresponding to the two steps of the degradation. At the beginning, the oxidation of benzene was fast and it was followed by the slow oxidation step. Most of the benzene was degraded during the first step.

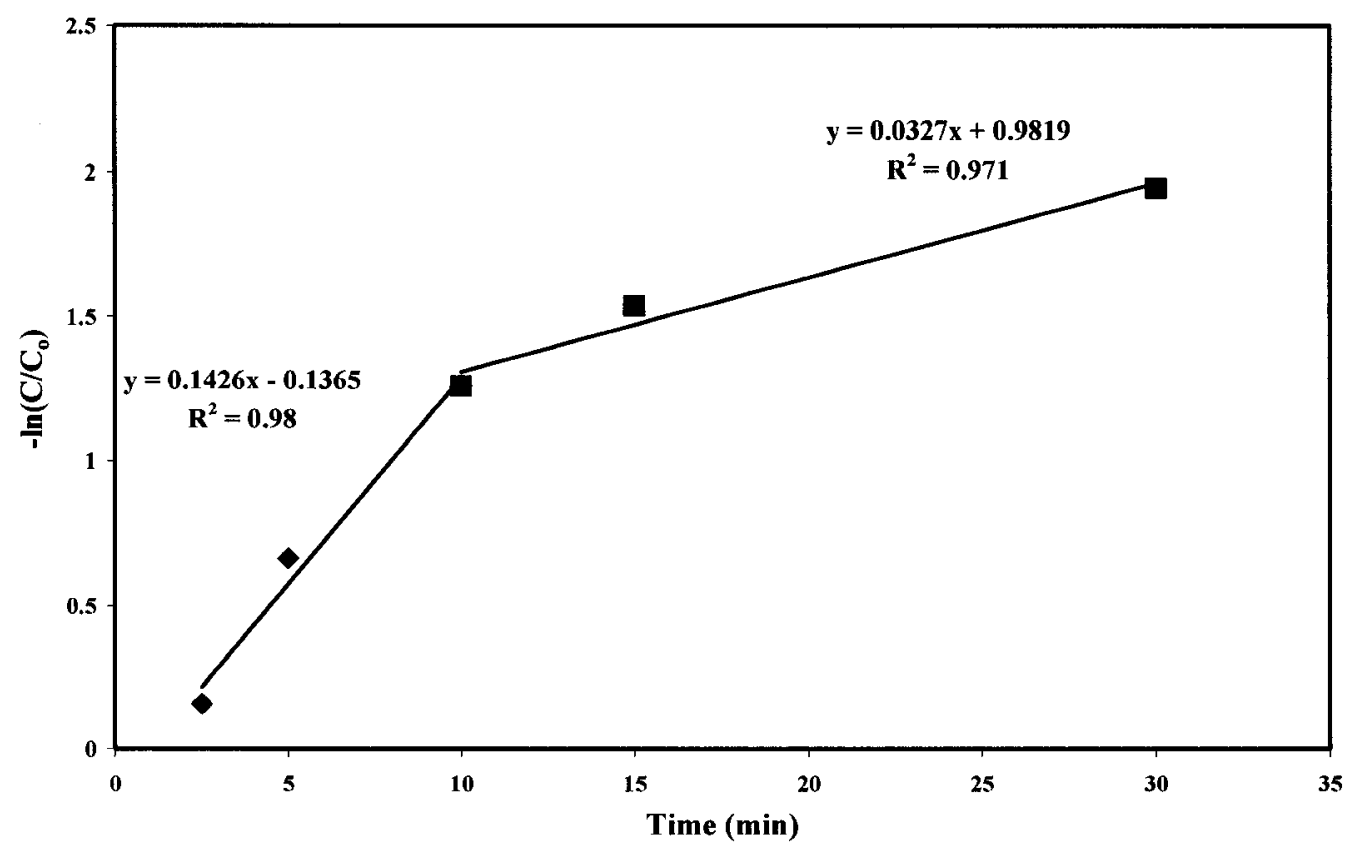

Figure 4.30: First Order Kinetic Model Fit of Benzene Degradation, $\mathrm{T}=220^{\circ} \mathrm{C}$, $\mathrm{P}_{\mathrm{O} 2}=0.69 \mathrm{MPa}, \mathrm{pH}=4$. 


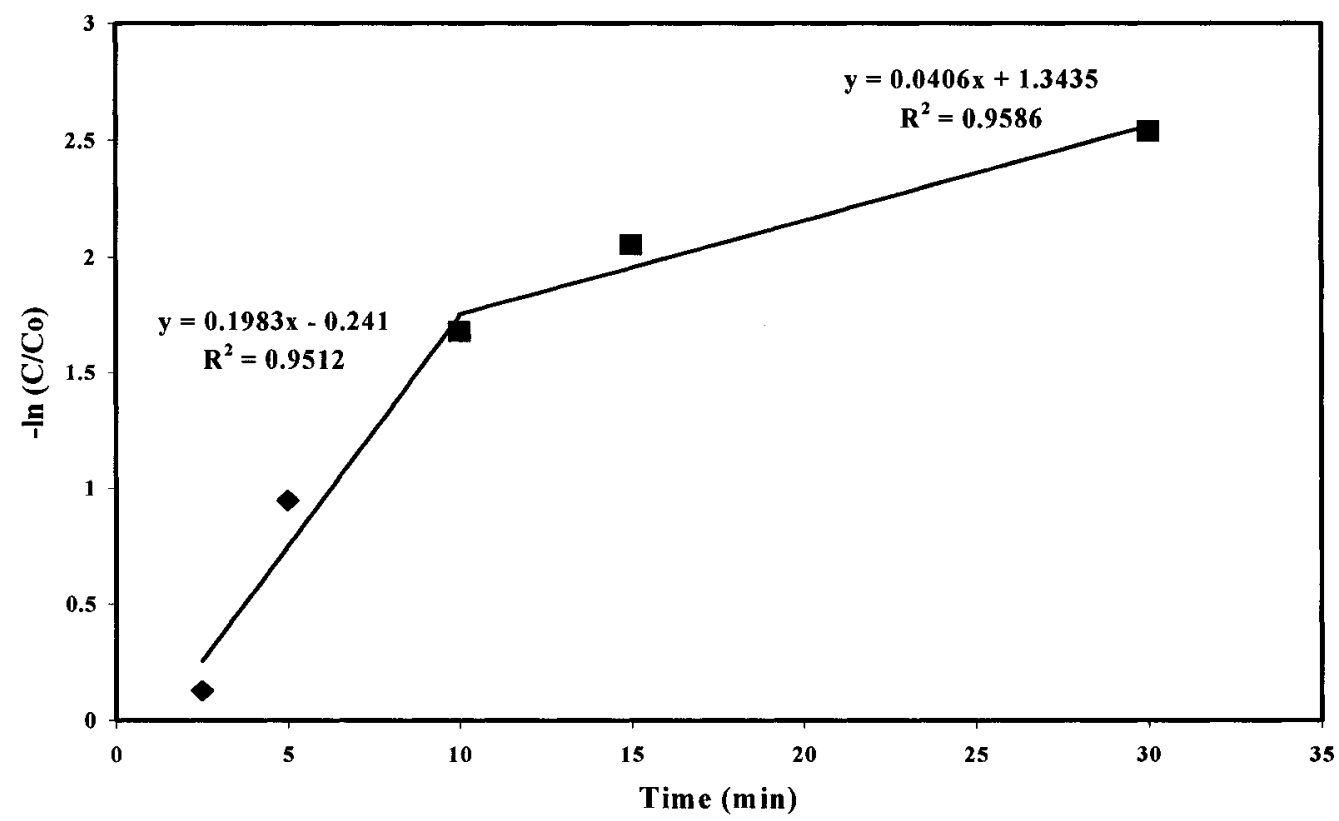

Figure 4.31: First Order Kinetic Model Fit of Benzene Degradation, $\mathrm{T}=220^{\circ} \mathrm{C}$, $\mathrm{P}_{\mathrm{O} 2}=0.86 \mathrm{MPa}, \mathrm{pH}=4$.

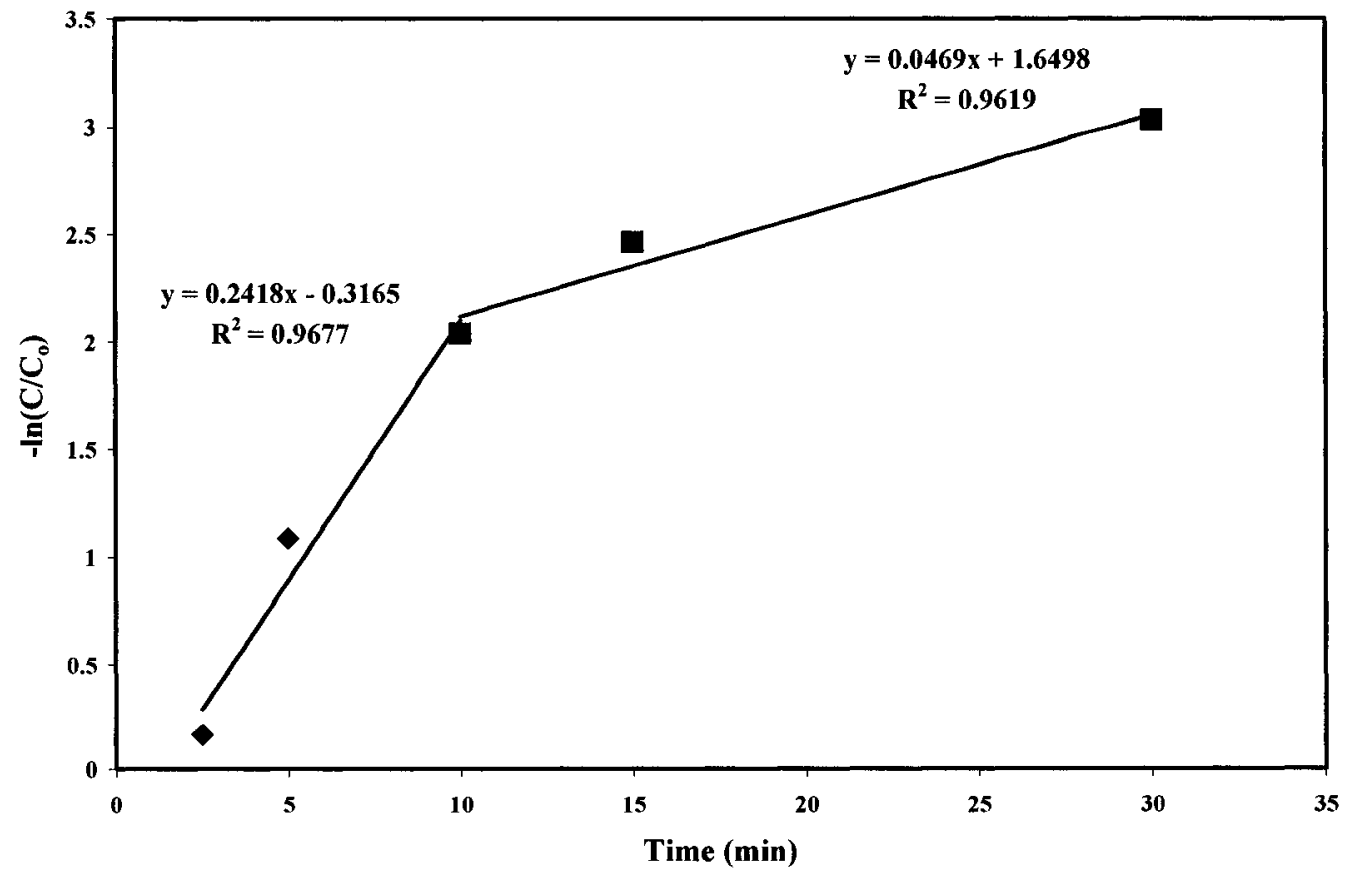

Figure 4.32: First Order Kinetic Model Fit of Benzene Degradation, $\mathrm{T}=220^{\circ} \mathrm{C}$, $\mathrm{P}_{\mathrm{O} 2}=1.03 \mathrm{MPa}, \mathrm{pH}=4$. 


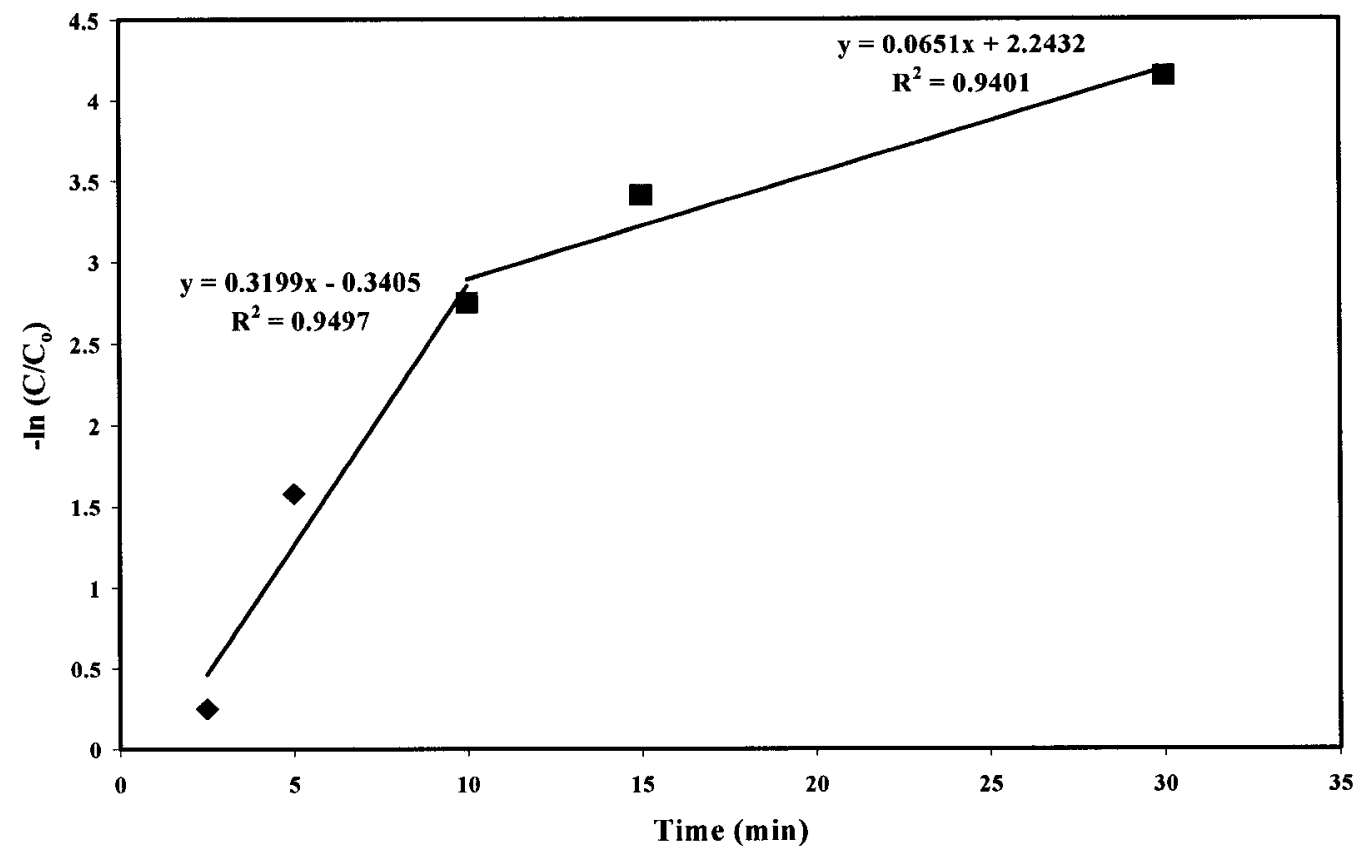

Figure 4.33: First Order Kinetic Model Fit of Benzene Degradation, $\mathrm{T}=220^{\circ} \mathrm{C}$, $\mathrm{P}_{\mathrm{O} 2}=1.38 \mathrm{MPa}, \mathrm{pH}=4$.

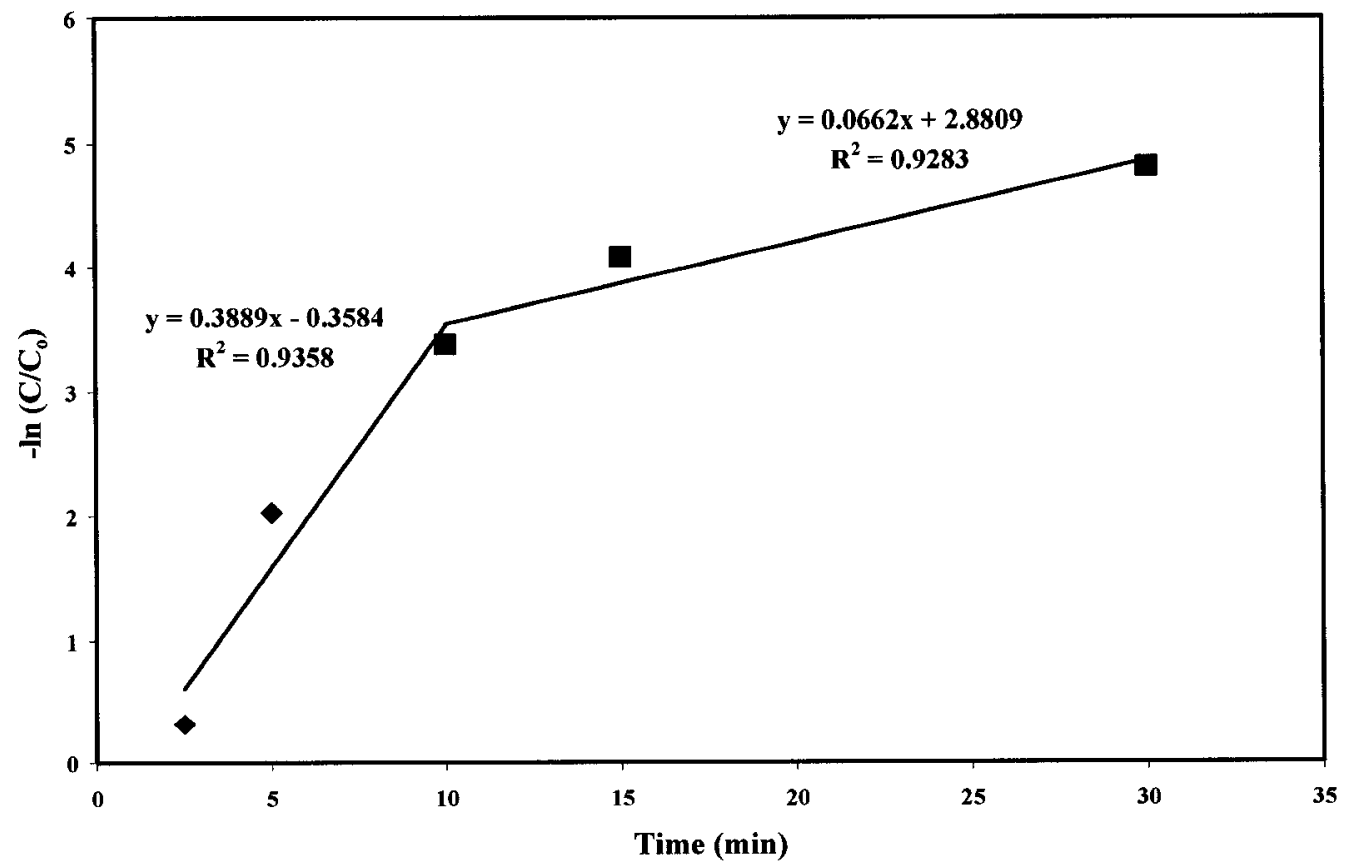

Figure 4.34: First Order Kinetic Model Fit of Benzene Degradation, $\mathrm{T}=220^{\circ} \mathrm{C}$, $\mathrm{P}_{\mathrm{O} 2}=1.72 \mathrm{MPa}, \mathrm{pH}=4$. 
From those figures $\mathrm{k}^{\prime}$, which is equal to the reaction rate constant $(\mathrm{k})$ multiplied by the oxygen pressure $\mathrm{P}_{\mathrm{O} 2}$, can be calculated and the values are summarized in Table 4.2.

Table 4.2: $\mathrm{k}^{\prime}$ Values at Different $\mathrm{P}_{\mathrm{O} 2}$ for the Fast Step, $\mathrm{T}=220^{\circ} \mathrm{C}$.

\begin{tabular}{||c|c||}
\hline $\mathbf{P}_{\mathbf{O} 2}(\mathbf{M P a})$ & $\mathbf{k}^{\prime}$ \\
\hline 0.69 & 0.1426 \\
\hline 0.86 & 0.1983 \\
\hline 1.03 & 0.2418 \\
\hline 1.38 & 0.3199 \\
\hline 1.72 & 0.3889 \\
\hline
\end{tabular}

The first order kinetic model fit for 240 and $260^{\circ} \mathrm{C}$ and different oxygen pressure can be found at figures $4.35-4.37$ and figures $4.38-4.40$, respectively.

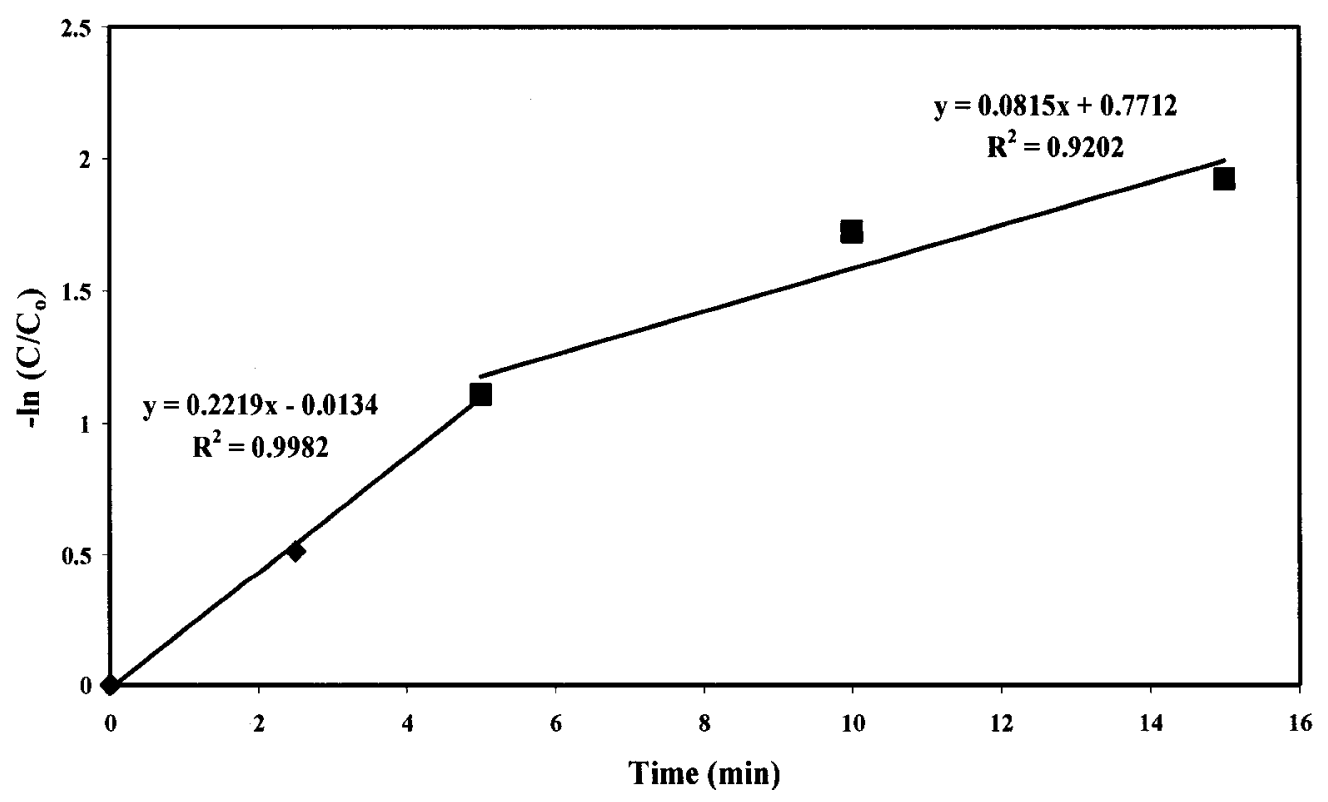

Figure 4.35: First Order Kinetic Model Fit of Benzene Degradation, $\mathrm{T}=240^{\circ} \mathrm{C}$, $\mathrm{P}_{\mathrm{O} 2}=1.03 \mathrm{MPa}, \mathrm{pH}=4$. 


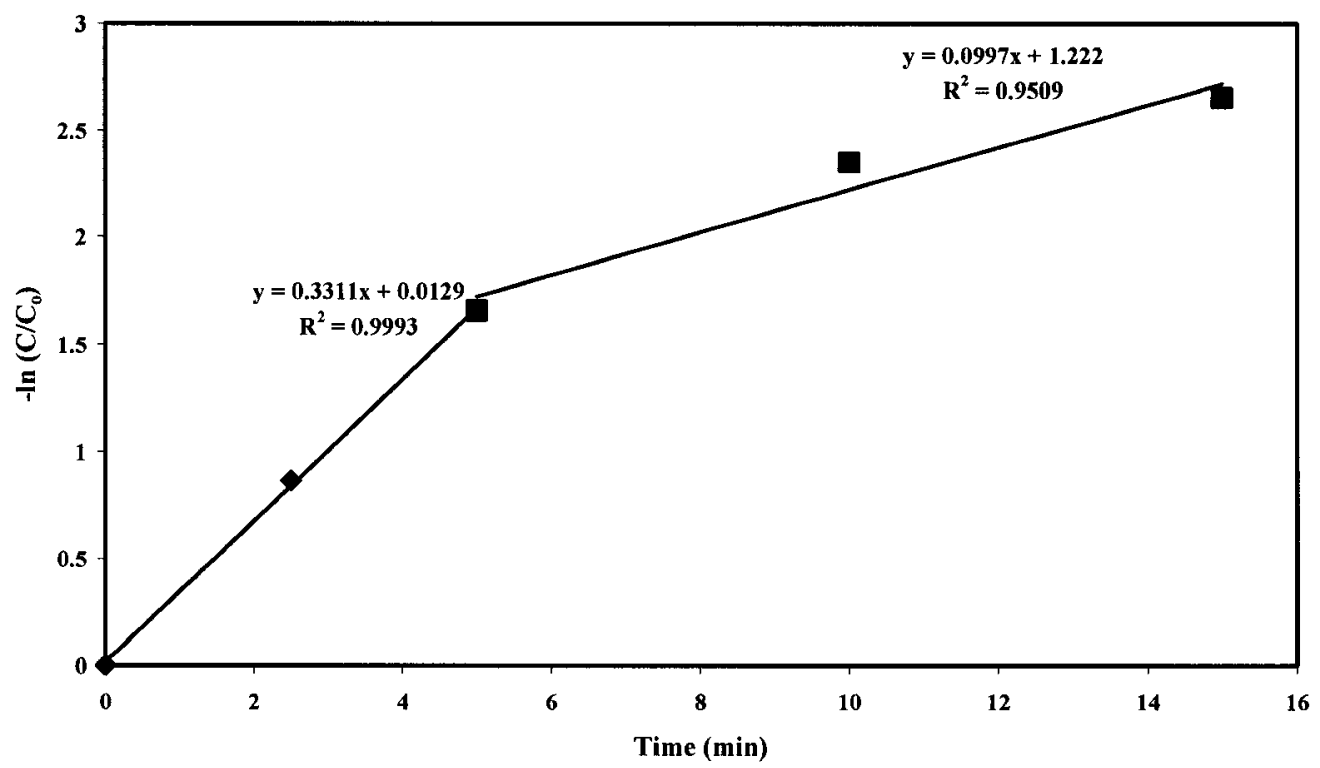

Figure 4.36: First Order Kinetic Model Fit of Benzene Degradation, $\mathrm{T}=240^{\circ} \mathrm{C}$, $\mathrm{P}_{\mathrm{O} 2}=1.38 \mathrm{MPa}, \mathrm{pH}=4$.

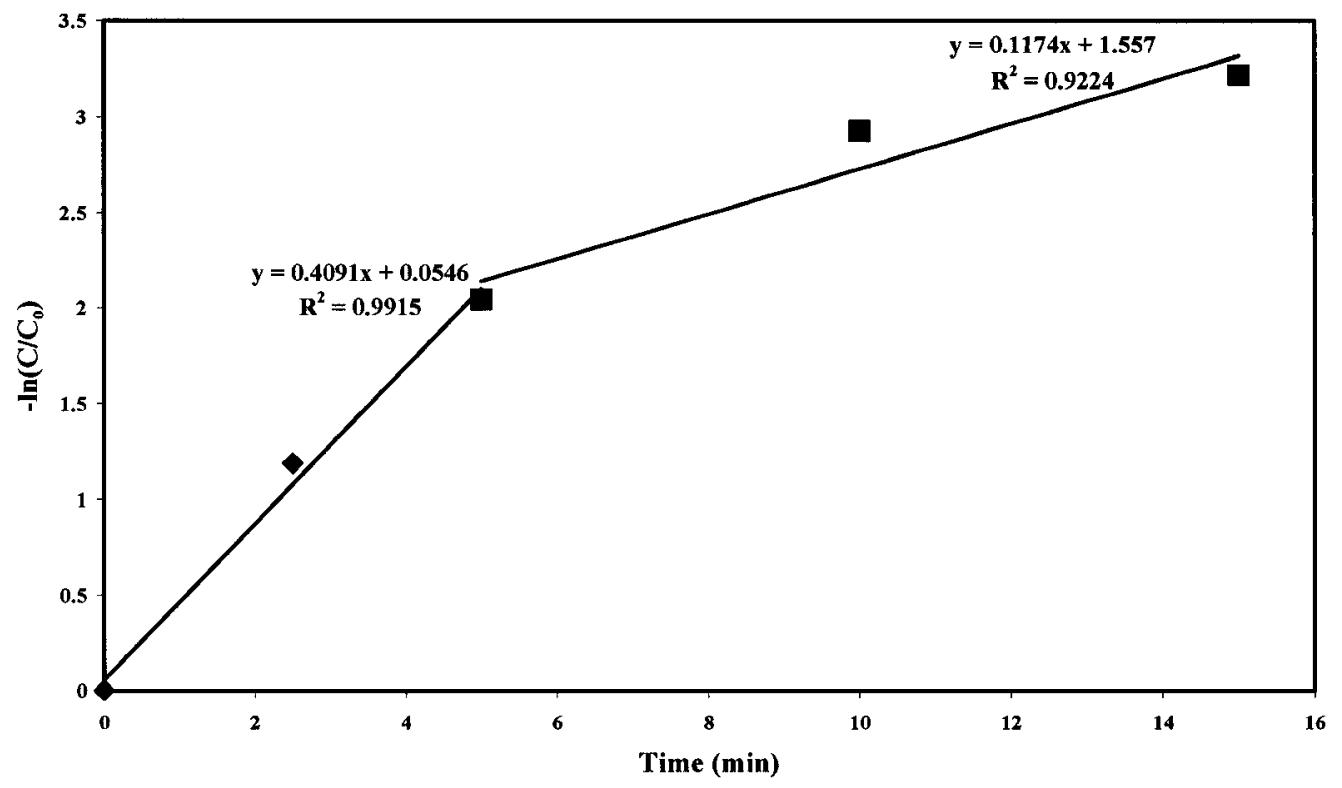

Figure 4.37: First Order Kinetic Model Fit of Benzene Degradation, $\mathrm{T}=240^{\circ} \mathrm{C}$, $\mathrm{P}_{\mathrm{O} 2}=1.72 \mathrm{MPa}, \mathrm{pH}=4$. 


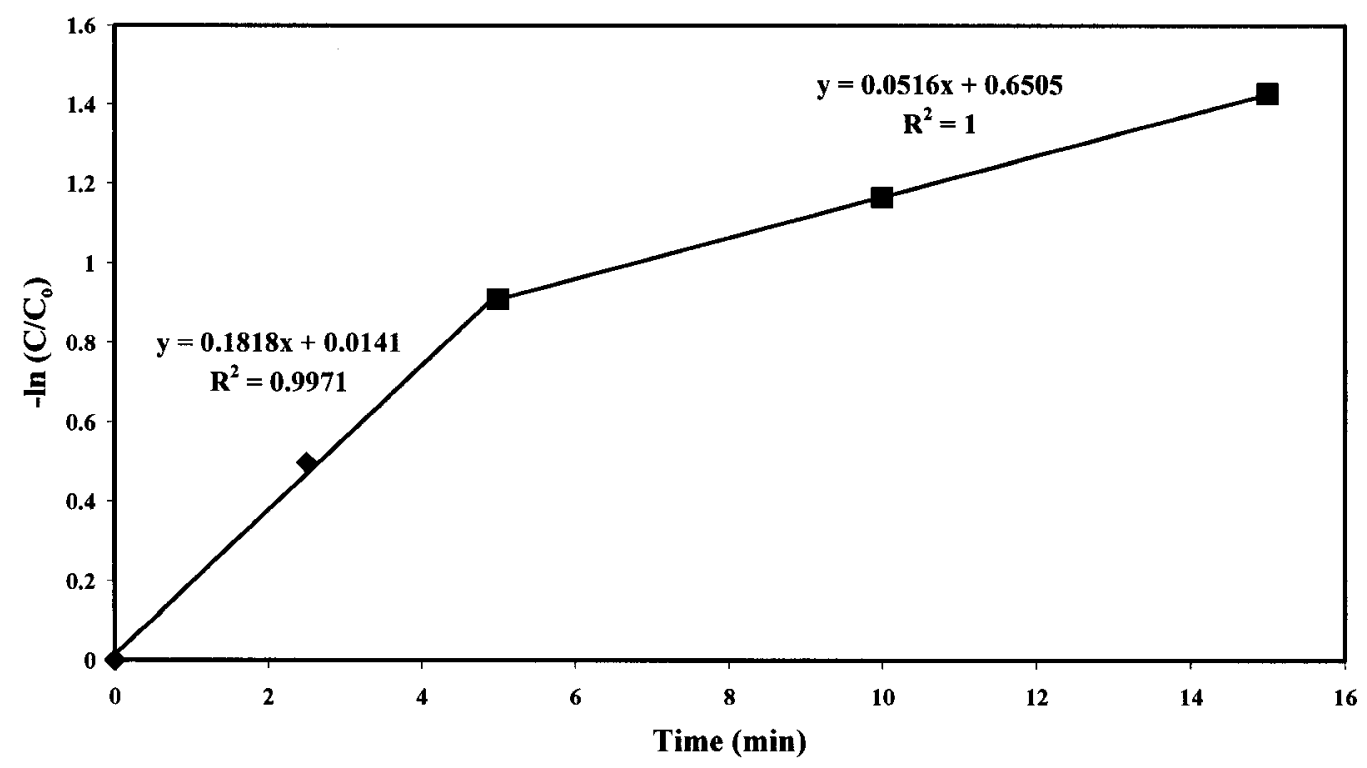

Figure 4.38: First Order Kinetic Model Fit of Benzene Degradation, $\mathrm{T}=260^{\circ} \mathrm{C}$, $\mathrm{P}_{\mathrm{O} 2}=1.03 \mathrm{MPa}, \mathrm{pH}=4$.

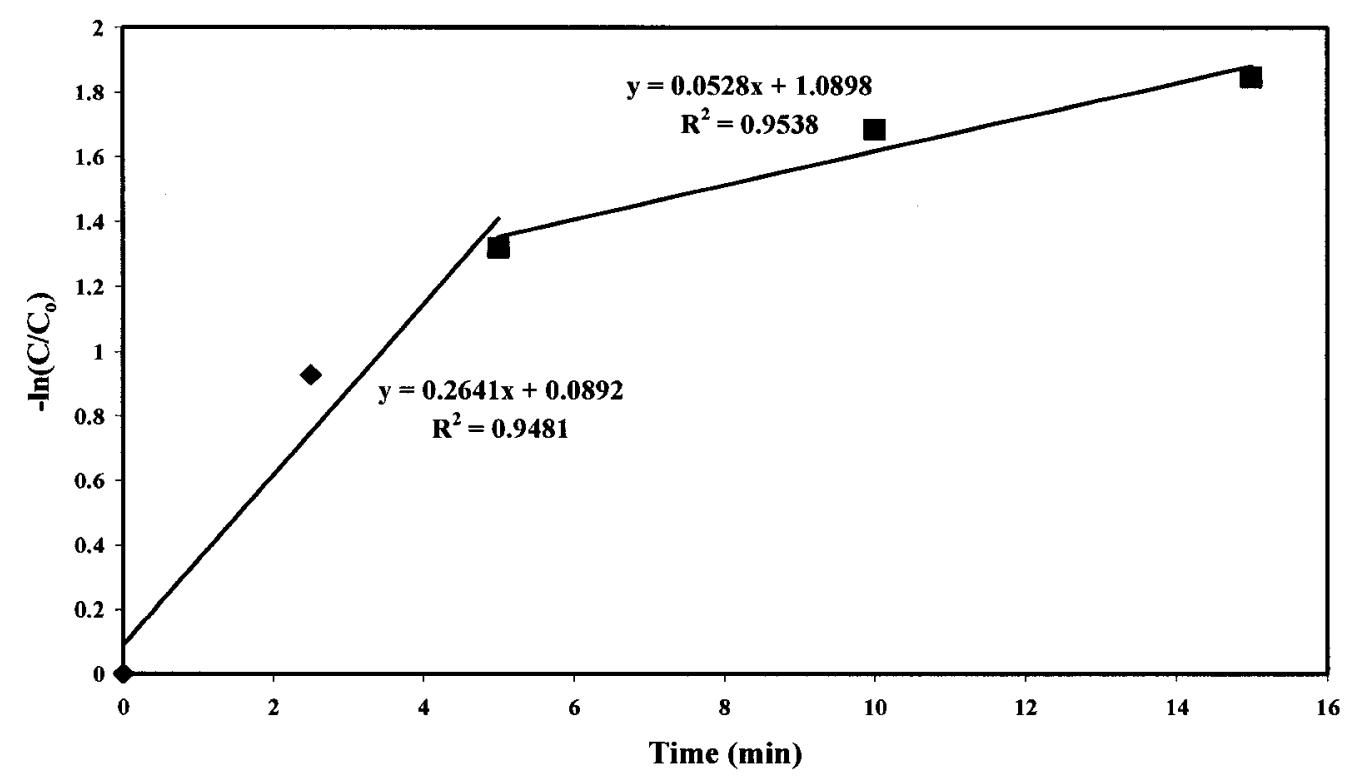

Figure 4.39: First Order Kinetic Model Fit of Benzene Degradation, $\mathrm{T}=260^{\circ} \mathrm{C}$, $\mathrm{P}_{\mathrm{O} 2}=1.38 \mathrm{MPa}, \mathrm{pH}=4$. 


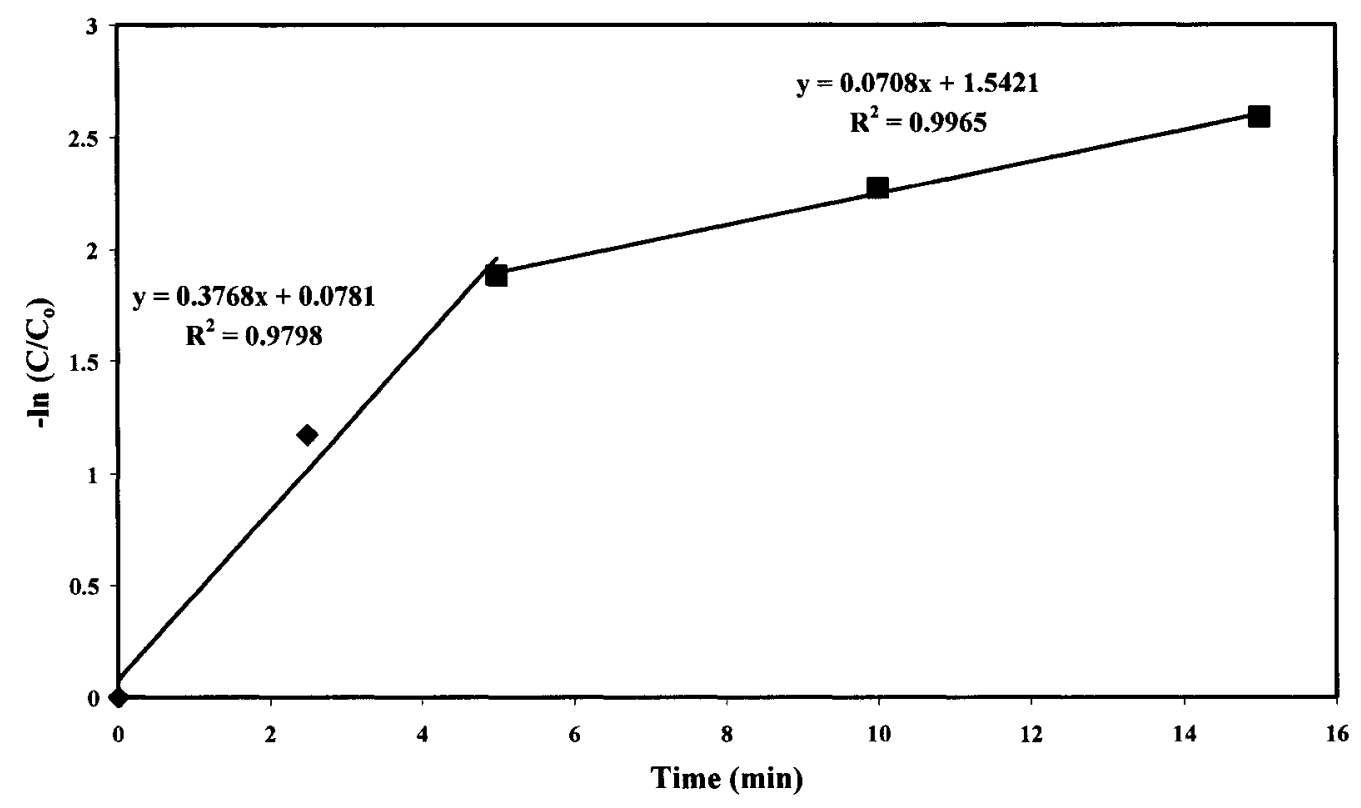

Figure 4.40: First Order Kinetic Model Fit of Benzene Degradation, $\mathrm{T}=260^{\circ} \mathrm{C}$, $\mathrm{P}_{\mathrm{O} 2}=1.72 \mathrm{MPa}, \mathrm{pH}=4$.

From the above figures $\mathrm{k}^{\prime}$ can be calculated for both 240 and $260^{\circ} \mathrm{C}$ and the values are presented at Table 4.3 and 4.4, respectively.

Table 4.3: $\mathrm{k}$ ' Values at Different $\mathrm{P}_{\mathrm{O} 2}$ for the Fast Step, $\mathrm{T}=240^{\circ} \mathrm{C}$.

\begin{tabular}{||c|c||}
\hline $\mathbf{P}_{\mathbf{O} 2}(\mathbf{M P a})$ & $\mathbf{k}^{\prime}$ \\
\hline 1.03 & 0.2219 \\
\hline 1.38 & 0.3311 \\
\hline 1.72 & 0.4091 \\
\hline
\end{tabular}


Table 4.4: k' Values at Different $\mathrm{P}_{\mathrm{O} 2}$ for the Fast Step, $\mathrm{T}=260^{\circ} \mathrm{C}$.

\begin{tabular}{||c|c|}
\hline $\mathbf{P}_{\mathbf{O} 2}$ (MPa) & $\mathbf{k}^{\prime}$ \\
\hline 1.03 & 0.1818 \\
\hline 1.38 & 0.2641 \\
\hline 1.72 & 0.3768 \\
\hline
\end{tabular}

Figures 4.41-4.43 show plots of $\mathrm{k}^{\prime}$ against $\mathrm{P}_{\mathrm{O} 2}$ which are used to calculate the rate constant at 220,240 and $260^{\circ} \mathrm{C}$, respectively. Those figures also show that the reaction was first order with the oxygen pressure. The values for the rate constant can be found in Table 4.5.

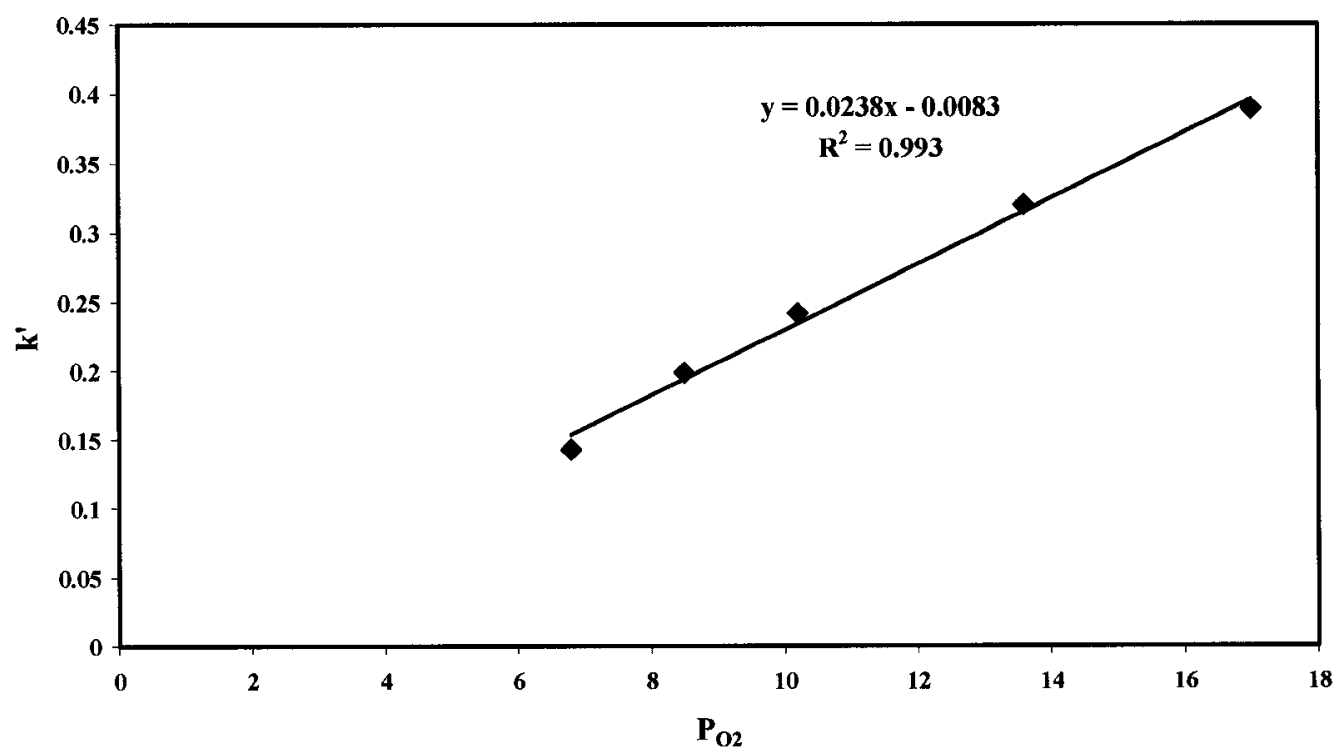

Figure 4.41: $\mathrm{k}$ ' vs. $\mathrm{P}_{\mathrm{O} 2}, \mathrm{~T}=220^{\circ} \mathrm{C}, \mathrm{pH}=4$. 


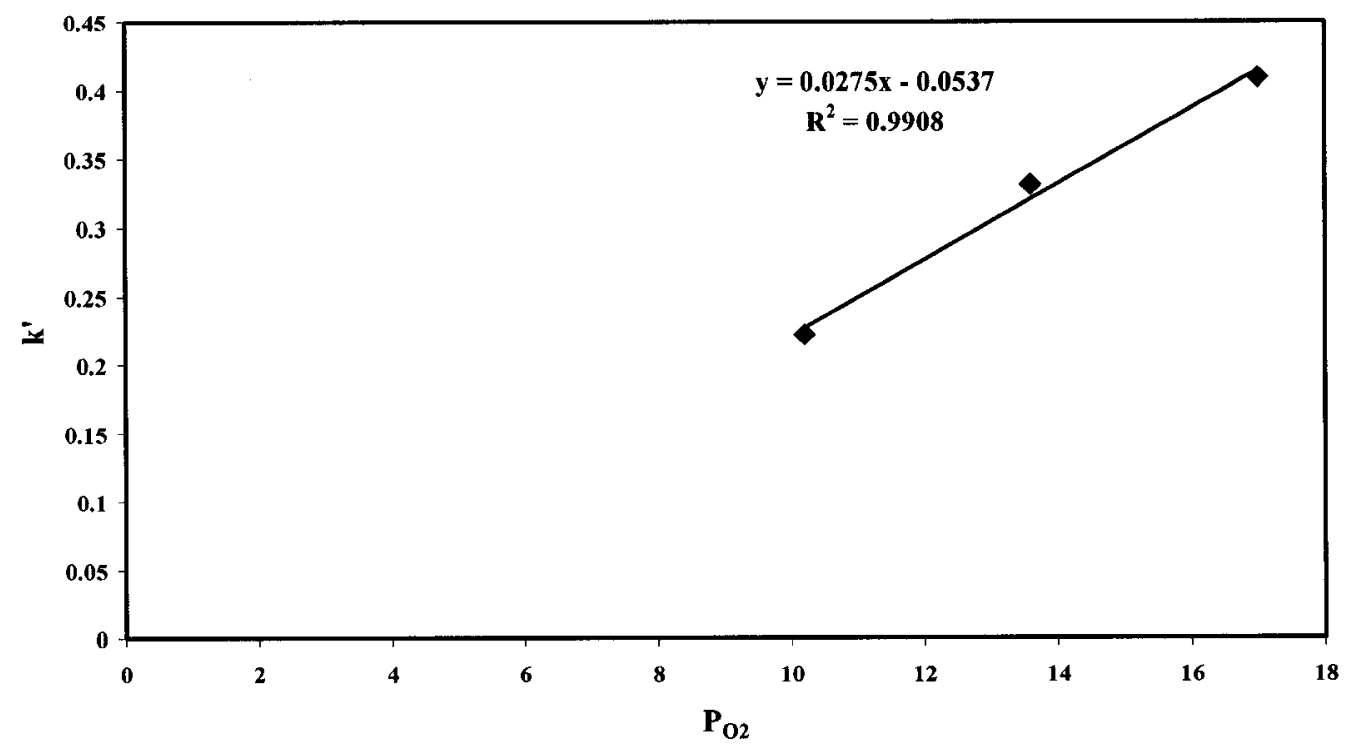

Figure 4.42: $\mathrm{k}^{\prime}$ vs. $\mathrm{P}_{\mathrm{O} 2}, \mathrm{~T}=240^{\circ} \mathrm{C}, \mathrm{pH}=4$.

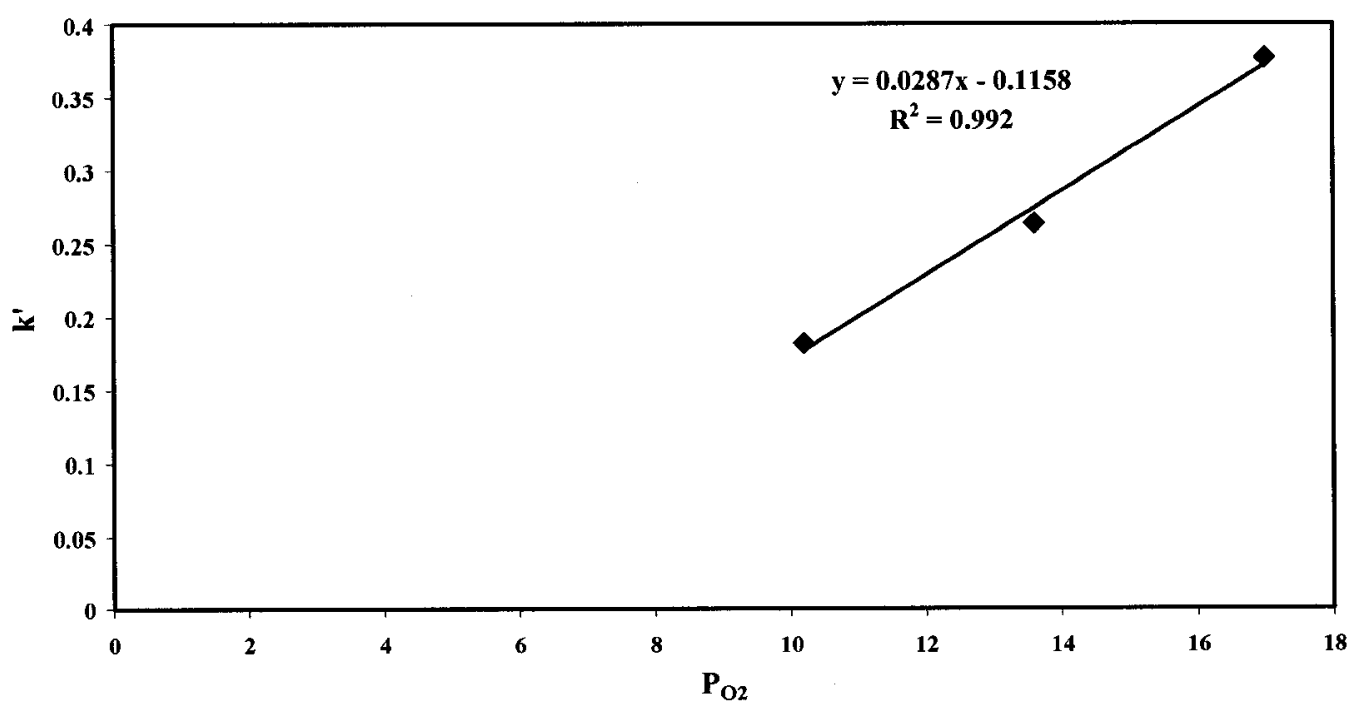

Figure 4.43: k' vs. $\mathrm{P}_{\mathrm{O} 2}, \mathrm{~T}=260^{\circ} \mathrm{C}, \mathrm{pH}=4$. 
Table 4.5: Rate Constant Value at Different Temperatures.

\begin{tabular}{||c|c||}
\hline $\mathbf{T}\left({ }^{\circ} \mathbf{C}\right)$ & $\mathbf{k}$ \\
\hline 220 & 0.0238 \\
\hline 240 & 0.0275 \\
\hline 260 & 0.0287 \\
\hline
\end{tabular}

The Arrhenius plot is shown in Figure 4.44. The activation energy for the fast step of the benzene oxidation can then be calculated from the plot to be $10.3 \mathrm{~kJ} / \mathrm{mol}$.

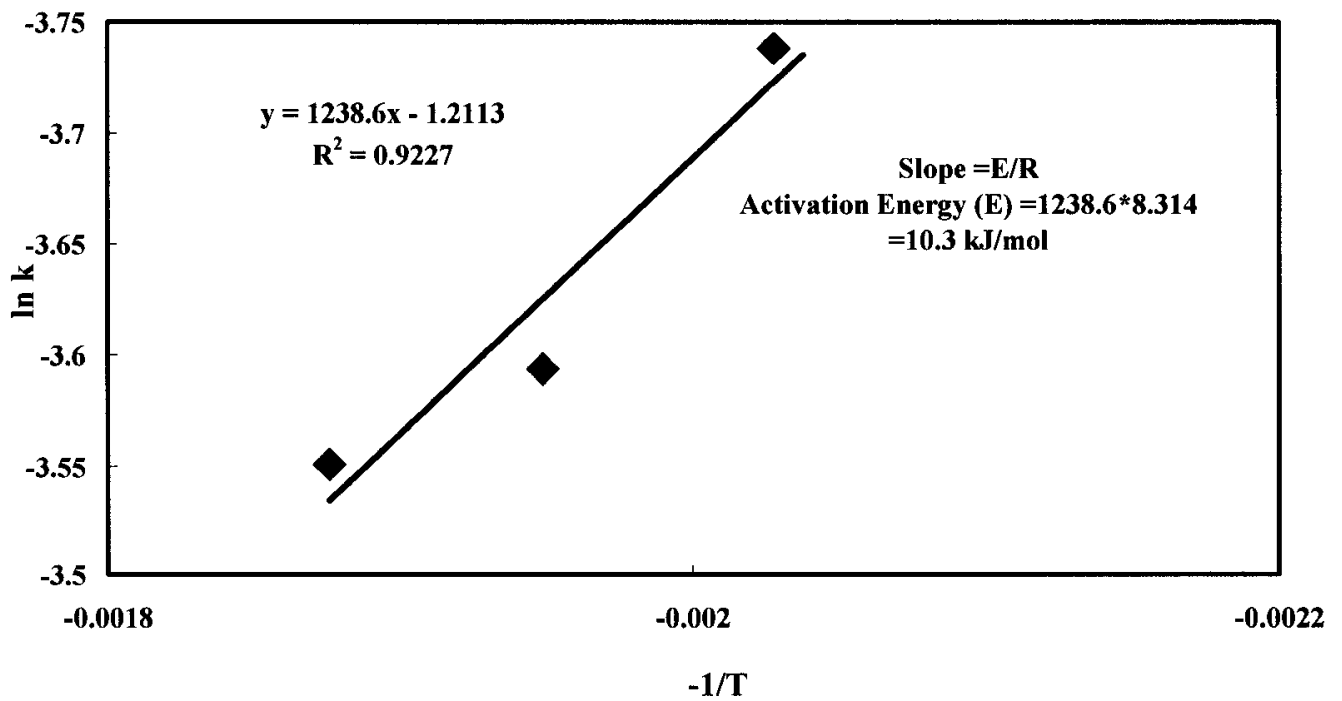

Figure 4.44: Arrhenius Plot for Oxidation of Benzene, $\mathrm{pH}=4$. 
In summary, it is apparent from the results obtained in this chapter that the wet air oxidation of benzene was affected by temperature, pressure and $\mathrm{pH}$. Also, it was shown that the wet air oxidation of benzene exhibited a two-step reaction. The initial step was fast followed by a slow rate of reaction. The oxidation rate was found to be first order with oxygen. The order with respect to benzene was found to be one in both steps. 


\section{CHAPTER FIVE}

\section{RESULTS AND DISCUSSIONS \\ REACTION INTERMEDIATES}

During the course of experiments, different reaction intermediates were produced. Most of those intermediates were oxidized further to the final products. Some of them were more stable during the oxidation under the experimental conditions and appeared as final products (e.g. the acetic acid). From an environmental point of view, it is important to know that the intermediates produced during waste treatment processes are not more harmful than the original materials in the waste effluent.

\subsection{Total Organic Carbon Measurements}

The Total Organic Carbon (TOC) measurements were performed in order to close the carbon balance, to demonstrate indirectly that the main reaction products were acetic acid and formic acid and that almost total degradation of benzene to $\mathrm{CO}_{2}$ and $\mathrm{H}_{2} \mathrm{O}$ was achieved. The effect of temperature on the formation of the intermediates was studied by measuring the TOC reduction during the experiment.

Figure 5.1 shows the TOC results obtained at oxygen pressure of $1.38 \mathrm{MPa}, \mathrm{pH} 6$ and temperatures of 220,240 and $260^{\circ} \mathrm{C}$. The results suggest that the higher the temperature, the faster the TOC reduction, especially within the first 60 minutes, implying that at higher temperature, the reaction proceeded fast to the final products. 


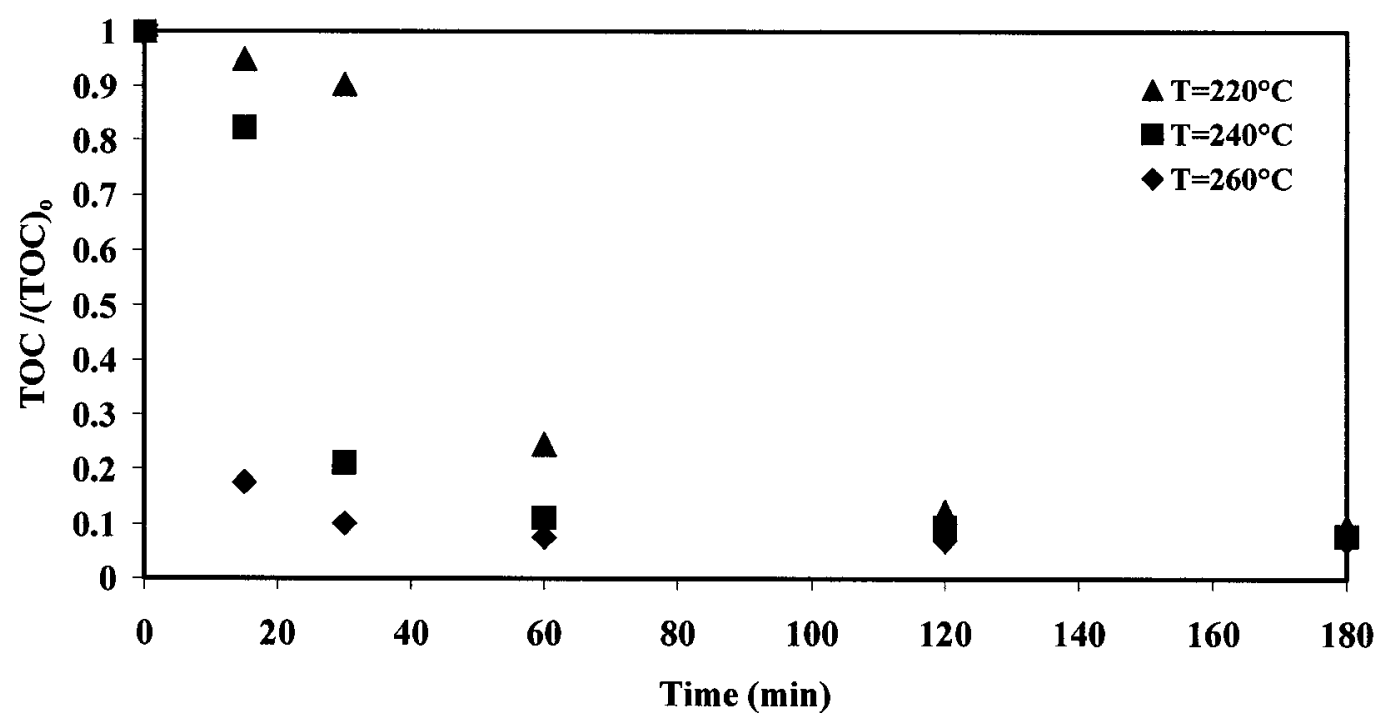

Figure 5.1: TOC Reduction with Time, $\mathrm{P}_{\mathrm{O} 2}=1.38 \mathrm{MPa}, \mathrm{pH}=6$.

Figures 5.2, 5.3 and 5.4 show the results from the TOC measurements together with the results that were calculated from the remaining benzene and the produced acids at 220,240 and $260^{\circ} \mathrm{C}$, respectively. The results show that the acetic acid was one of the final products and could not be degraded within the range of temperatures studied. The amount of TOC was compared to the total amount of carbon in the produced acetic acid, formic acid and in the remaining unreacted benzene during the experiment in order to verify the carbon balance. Figures 5.5, 5.6 and 5.7 show that the results obtained from the TOC measurement were comparable to the total amount of carbon that was calculated at 220,240 and $260^{\circ} \mathrm{C}$, respectively, confirming the carbon balance. It should be mentioned that negligible amounts of propanoic acid, glycolic acid and benzoquinone were detected during the oxidation at all conditions. 


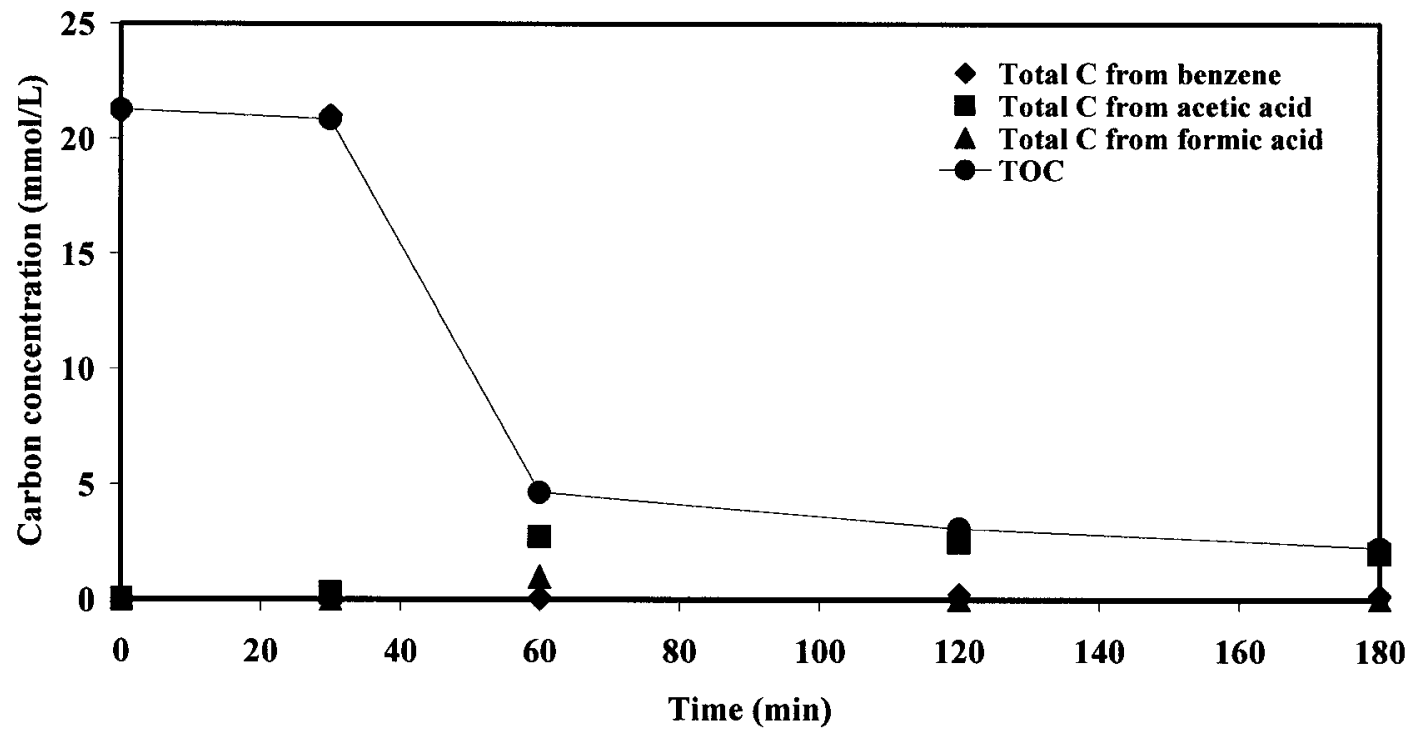

Figure 5.2: Detailed Change in Carbon Concentration with Time, $\mathrm{T}=220^{\circ} \mathrm{C}, \mathrm{pH}=6$, $\mathrm{P}_{\mathrm{O} 2}=1.38 \mathrm{MPa}$.

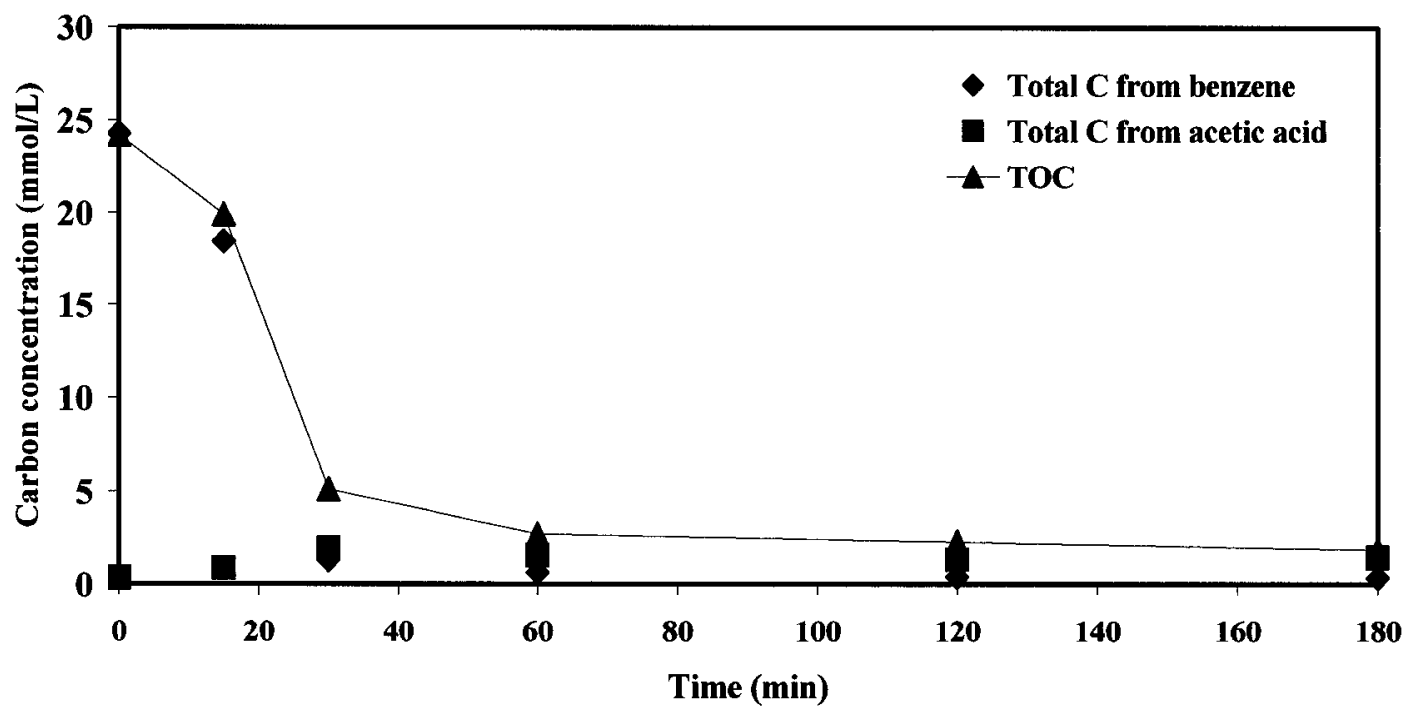

Figure 5.3: Detailed Change in Carbon Concentration with Time, $\mathrm{T}=240^{\circ} \mathrm{C}, \mathrm{pH}=6$, $\mathrm{P}_{\mathrm{O} 2}=1.38 \mathrm{MPa}$. 


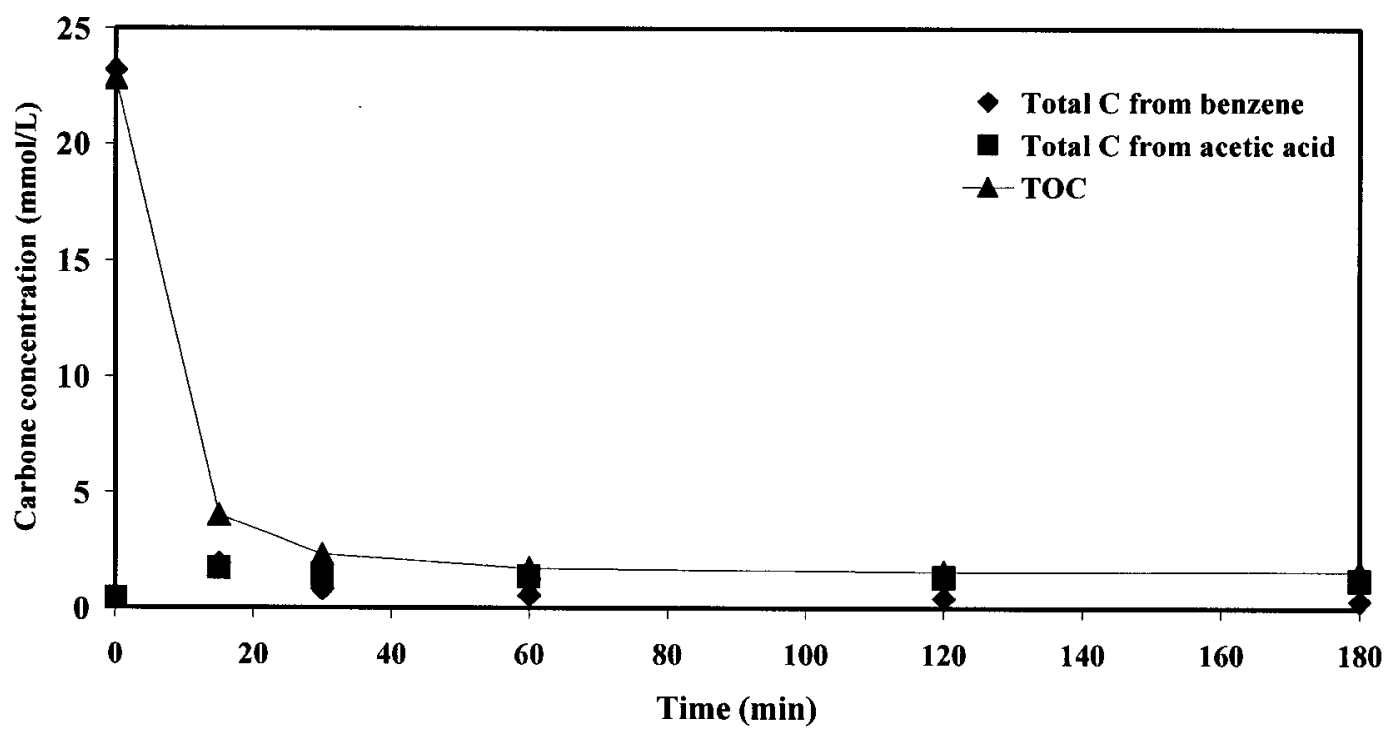

Figure 5.4: Detailed Change in Carbon Concentration with Time, $\mathrm{T}=260^{\circ} \mathrm{C}, \mathrm{pH}=6$, $\mathrm{P}_{\mathrm{O} 2}=1.38 \mathrm{MPa}$.

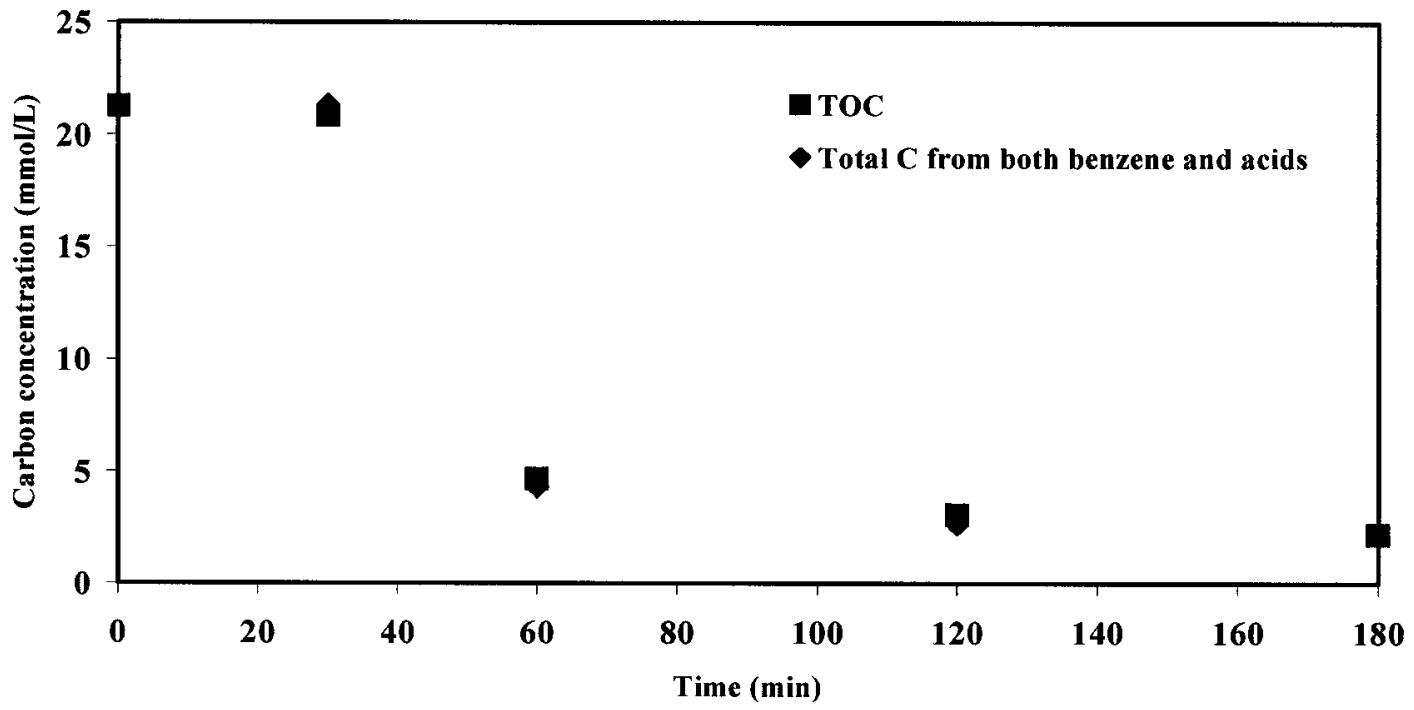

Figure 5.5: Carbon Balance, $\mathrm{T}=220^{\circ} \mathrm{C}, \mathrm{pH}=6, \mathrm{P}_{\mathrm{O} 2}=1.38 \mathrm{MPa}$. 


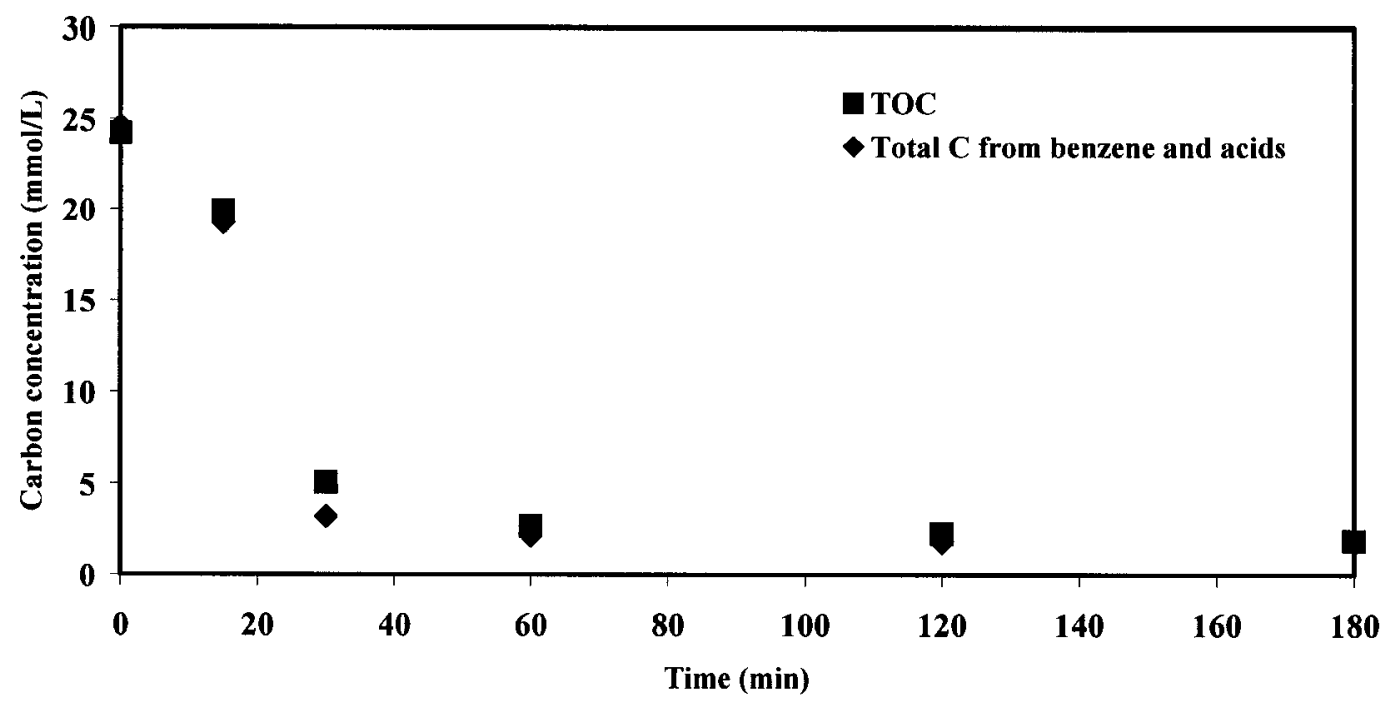

Figure 5.6: Carbon Balance, $\mathrm{T}=240^{\circ} \mathrm{C}, \mathrm{pH}=6, \mathrm{P}_{\mathrm{O} 2}=1.38 \mathrm{MPa}$.

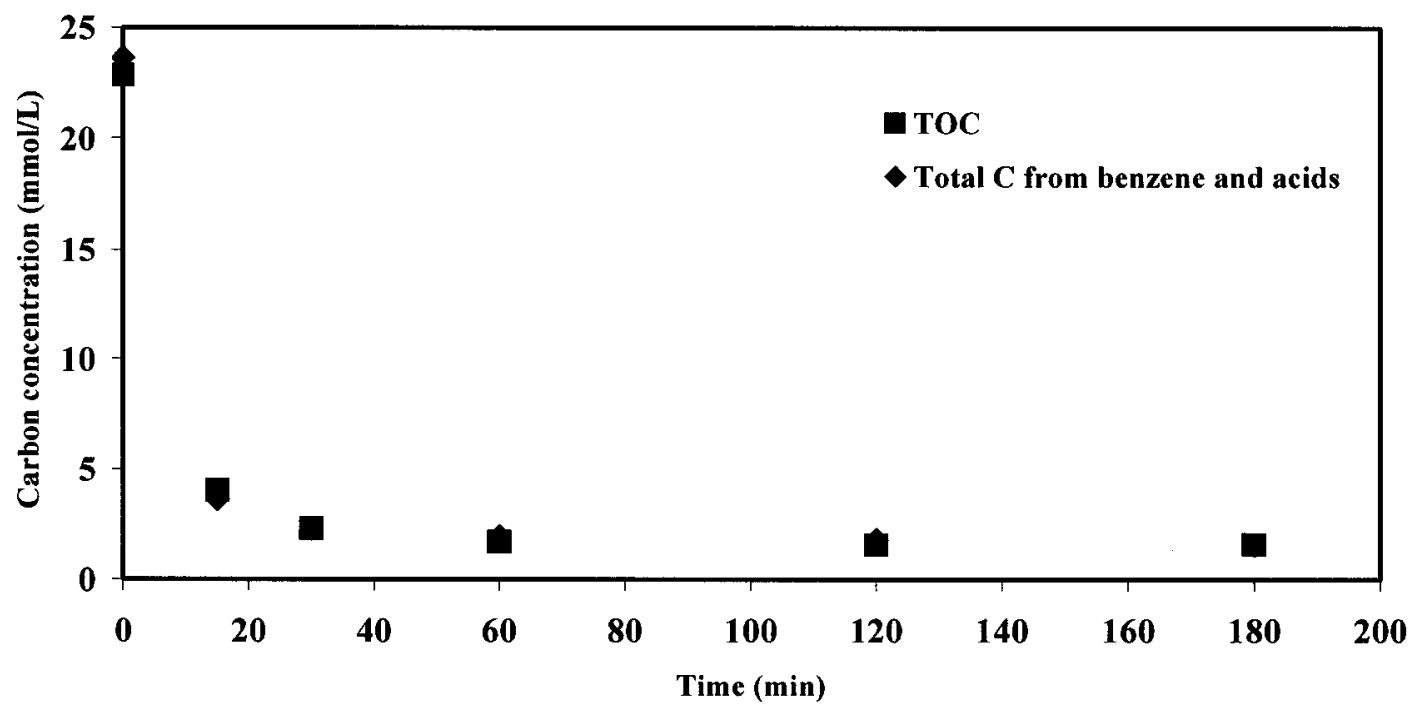

Figure 5.7: Carbon Balance, $\mathrm{T}=260^{\circ} \mathrm{C}, \mathrm{pH}=6, \mathrm{P}_{\mathrm{O} 2}=1.38 \mathrm{MPa}$. 
In order to test the repeatability of the results another set of experiments were done at $220^{\circ} \mathrm{C}, 240^{\circ} \mathrm{C}$ and $260^{\circ} \mathrm{C}$, respectively. The experiment were performed at pH 6 and 1.38 $\mathrm{MPa}$ of oxygen pressure. Figures 5.8, 5.9 and 5.10 show that the results shown in figures 5.5, 5.6 and 5.7 were repeatable.

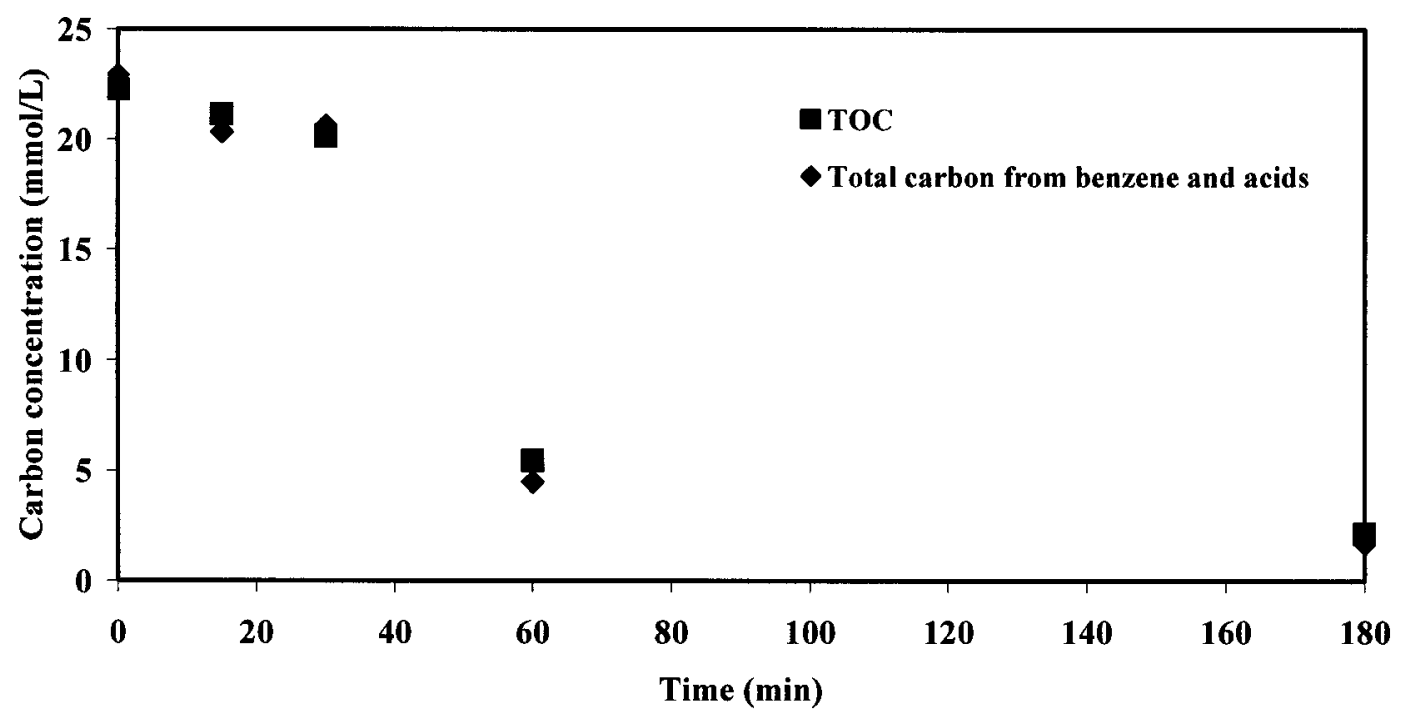

Figure 5.8: Repeatability of Carbon Balance, $\mathrm{T}=220^{\circ} \mathrm{C}, \mathrm{pH}=6, \mathrm{P}_{\mathrm{O} 2}=1.38 \mathrm{MPa}$.

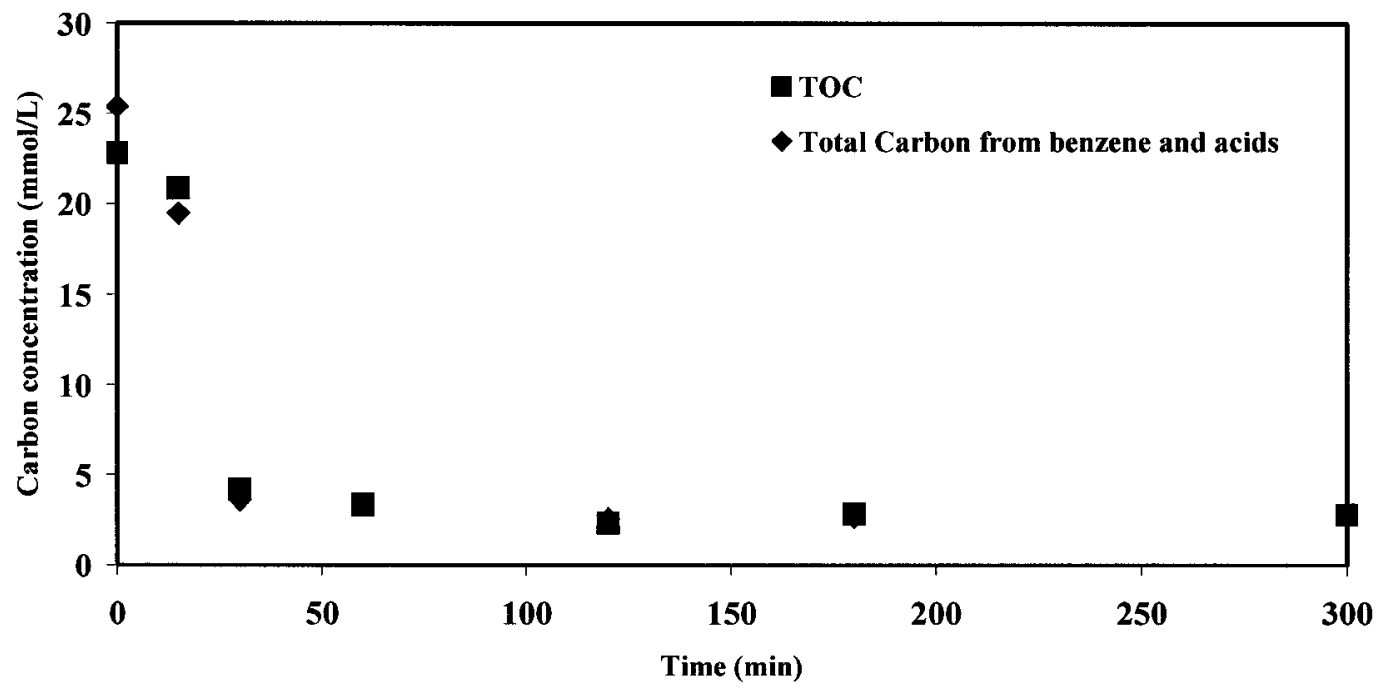

Figure 5.9: Repeatability of Carbon Balance, $\mathrm{T}=240^{\circ} \mathrm{C}, \mathrm{pH}=6, \mathrm{P}_{\mathrm{O} 2}=1.38 \mathrm{MPa}$. 


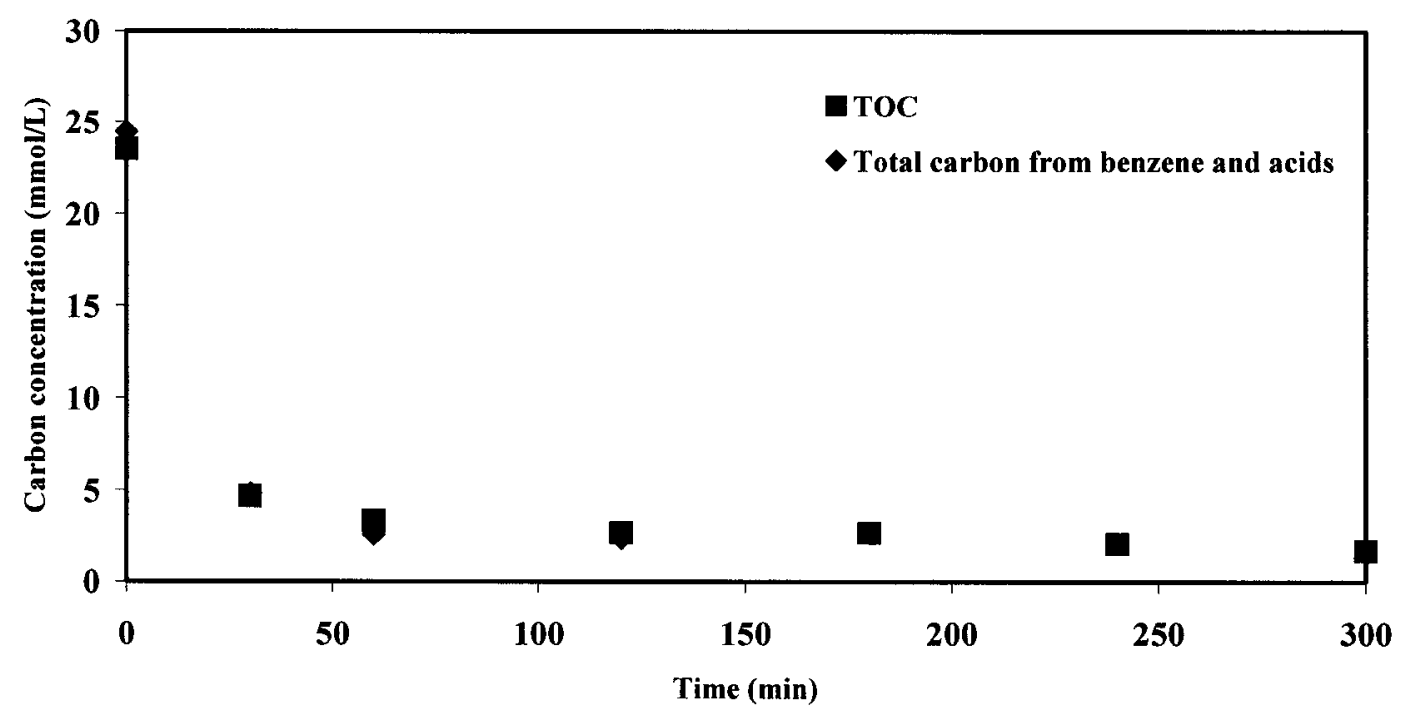

Figure 5.10: Repeatability of Carbon Balance, $\mathrm{T}=260^{\circ} \mathrm{C}, \mathrm{pH}=6, \mathrm{P}_{\mathrm{O} 2}=1.38 \mathrm{MPa}$.

In some experiments, the amount of carbon dioxide that was produced during the oxidation was measured and compared with the theoretical amount that should be present at the end of the reaction if only the acetic acid and the remaining unreacted benzene existed as final products. The carbon dioxide in both the gas phase and the liquid phase was measured at the end of the experiment. The amount of the carbon dioxide in the gas phase was collected by passing the gas through a solution of a $2 \mathrm{M} \mathrm{NaOH}$ in order to convert the carbon dioxide to carbonate, which could then be analyzed in the TOC analyzer. Table 5.1 shows the results for an experiment that was conducted at $260^{\circ} \mathrm{C}$, indicating a good agreement with those calculated theoretically. Detailed calculations can be found in the Appendix $\mathrm{C}$. 
Table 5.1: Carbon Dioxide Measurement, $\mathrm{pH}=6, \mathrm{P}_{\mathrm{O} 2}=1.38 \mathrm{MPa}$.

\begin{tabular}{|c|c|c|}
\hline $\begin{array}{c}\text { Temperature } \\
\left({ }^{\circ} \mathrm{C}\right)\end{array}$ & $\begin{array}{c}\text { Theoretical } \\
\mathrm{CO}_{2}(\mathrm{mmol})\end{array}$ & $\begin{array}{c}\text { Experimental } \\
\mathrm{CO}_{2}(\mathrm{mmol})\end{array}$ \\
\hline 260 & 21.4 & 20.8 \\
\hline
\end{tabular}

\subsection{Effect of Temperature on the Production and Degradation of both Acetic Acid and Formic Acid}

In this section the results of the generation and degradation of acetic acid are shown at 220,240 and $260^{\circ} \mathrm{C}$ and at different $\mathrm{pH}$. In those experiments, the oxygen pressure was kept at $1.38 \mathrm{MPa}$. The results as shown in Figures 5.11 and 5.12 have been obtained at $\mathrm{pH} 6$ and $\mathrm{pH} 4$, respectively. In both cases the production of acetic acid reached a maximum followed by a partial degradation as the experiment proceeded. Also, it can be noted that at all temperatures some of the acetic acid produced during the process was further oxidized. However, since the reaction at $\mathrm{pH} 4$ was faster, the production of acetic acid started earlier than at $\mathrm{pH}$ 6. At $\mathrm{pH} \mathrm{4,} \mathrm{at} \mathrm{the} \mathrm{higher} \mathrm{temperature} \mathrm{smaller} \mathrm{amounts} \mathrm{of}$ acetic acid were produced suggesting that at higher temperature most of the benzene is converted directly to the final product, which is the carbon dioxide. Another explanation may be due to fast degradation of the acetic acid at the beginning of the reaction at higher temperature. 


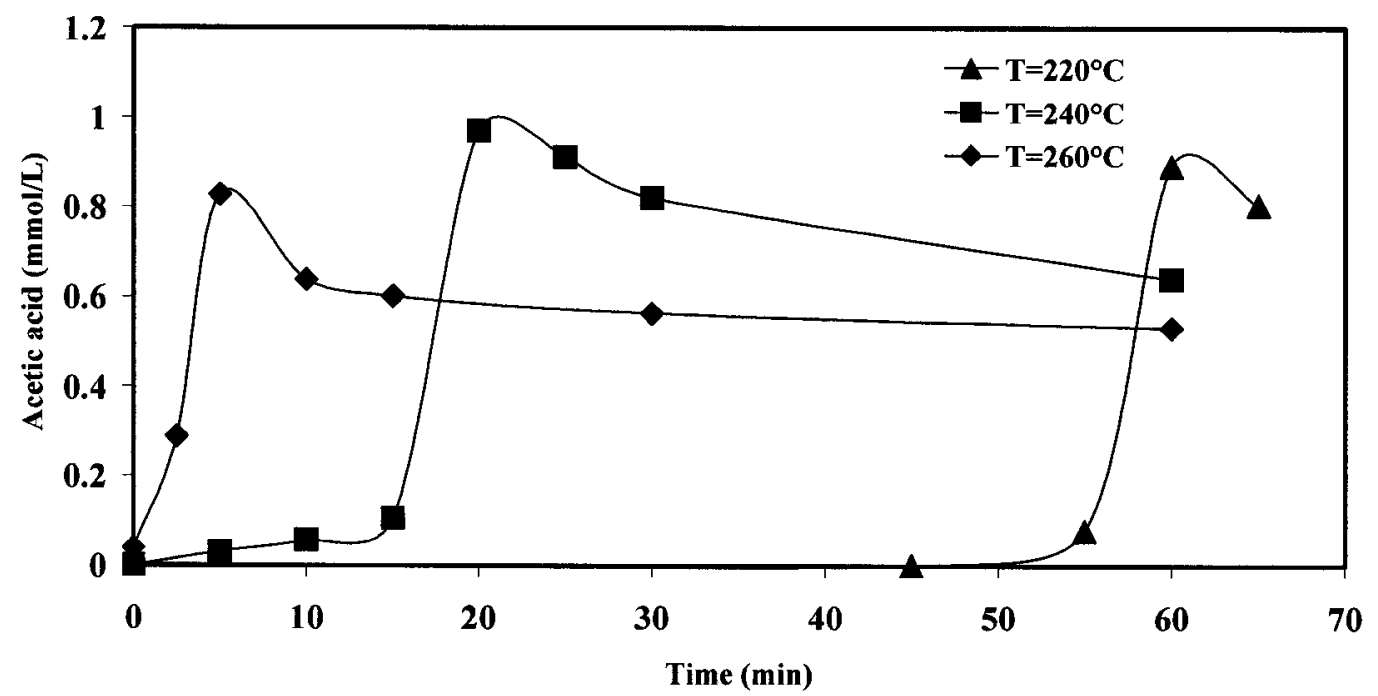

Figure 5.11: Effect of Temperature on Acetic Acid, $\mathrm{P}_{\mathrm{O} 2}=1.38 \mathrm{MPa}, \mathrm{pH}=6$.

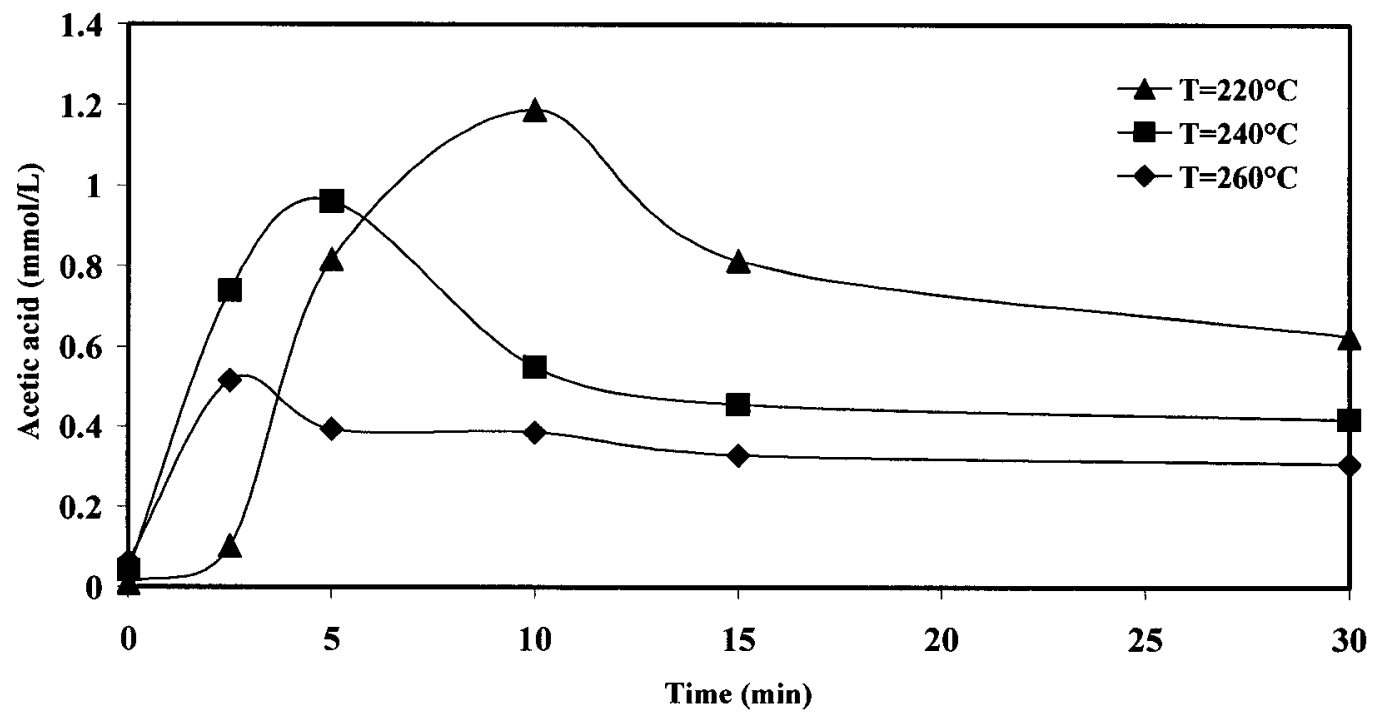

Figure 5.12: Effect of Temperature on Acetic Acid, $\mathrm{P}_{\mathrm{O} 2}=1.38 \mathrm{MPa}, \mathrm{pH}=4$. 
Unlike the acetic acid, the formic acid produced during the WAO was completely degraded to $\mathrm{CO}_{2}$ and $\mathrm{H}_{2} \mathrm{O}$, especially at higher temperature. Figures 5.13 and 5.14 show the results obtained for formic acid at different temperatures for $\mathrm{pH} 6$ and $\mathrm{pH} 4$, respectively. At $\mathrm{pH} 6$, all the formic acid produced at $260^{\circ} \mathrm{C}$ and most produced at $240^{\circ} \mathrm{C}$, was degraded after 60 minutes of oxidation. However, at $220^{\circ} \mathrm{C}$ due to slow reaction, the production of formic acid started late and it did not get degraded during the course of the experiment. In contrast, at $\mathrm{pH} 4$, as the temperature increased less formic acid was produced. Also, as the temperature increased the degradation of formic acid became faster, i.e. no formic acid was found after 15 minutes at $260^{\circ} \mathrm{C}$. This will be further explored in section 5.6 where the WAO of acetic acid and formic acid is discussed.

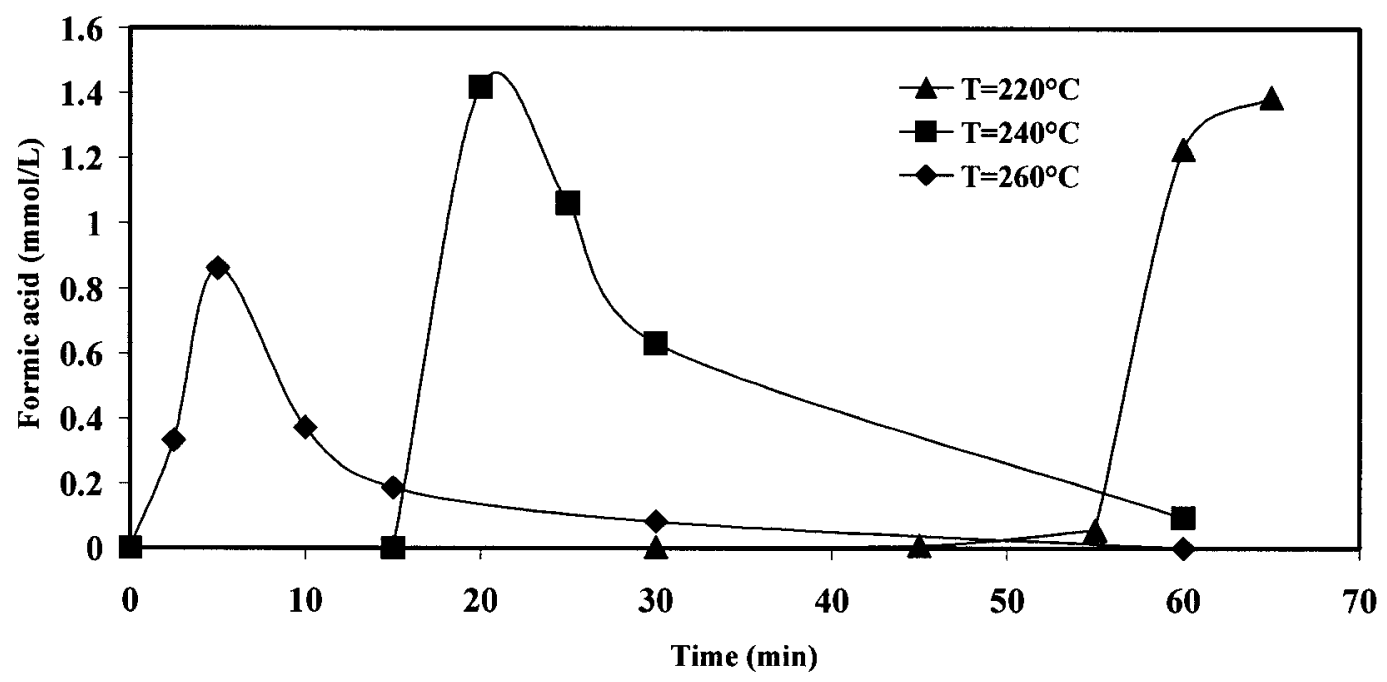

Figure 5.13: Effect of Temperature on Formic Acid, $\mathrm{P}_{\mathrm{O} 2}=1.38 \mathrm{MPa}, \mathrm{pH}=6$. 


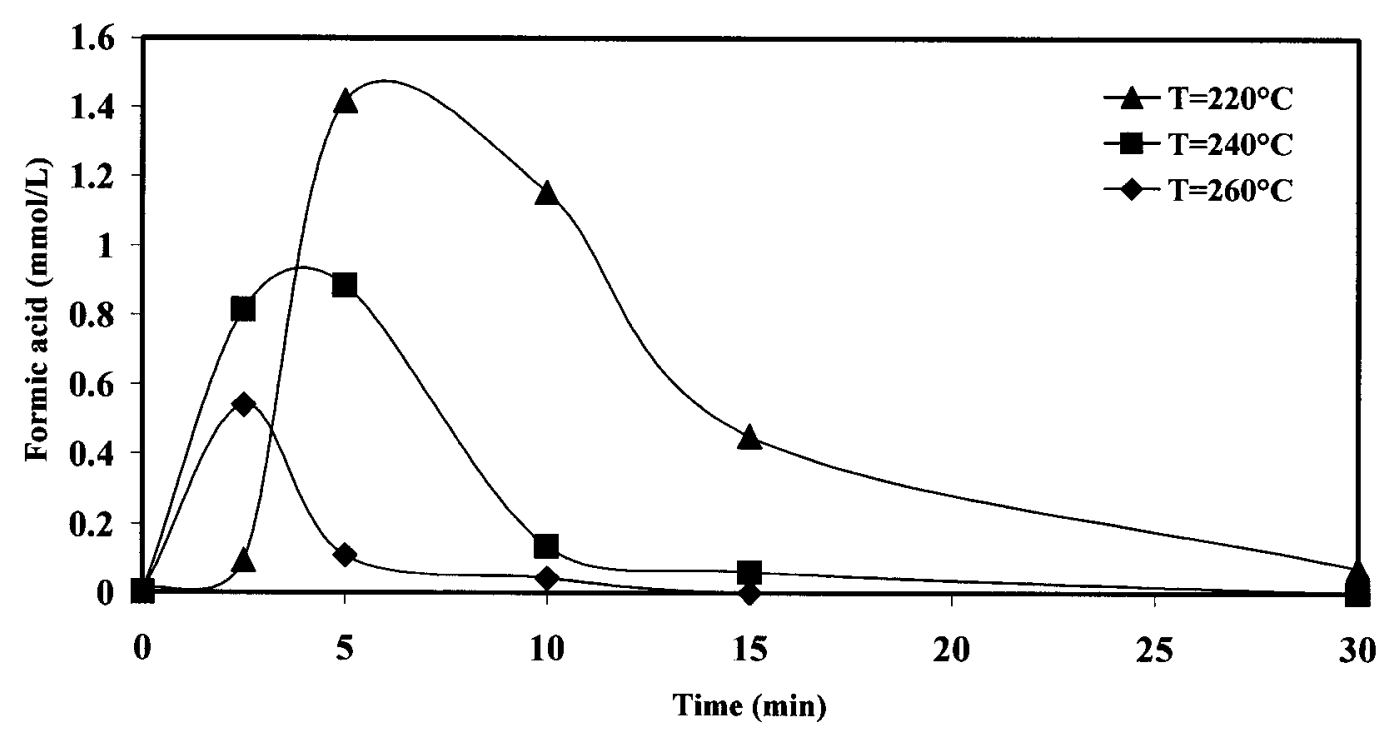

Figure 5.14: Effect of Temperature on Formic Acid, $\mathrm{P}_{\mathrm{O}_{2}}=1.38 \mathrm{MPa}, \mathrm{pH}=4$.

\subsection{Effect of Oxygen Pressure on the Production and Degradation of both Acetic Acid and Formic Acid}

The effect of oxygen pressure was studied at different temperatures and different $\mathrm{pH}$ levels. Figures 5.15 and 5.16 show the effect of oxygen pressure on both the acetic and the formic acids, respectively, at $260^{\circ} \mathrm{C}$ and $\mathrm{pH} 6$. At all pressures the same trend was observed for acetic acid, except that at lower pressure the acetic acid production was slower due to the slower benzene degradation. At all pressures, acetic acid remained as one of the final products while most of the formic acid produced was completely degraded to $\mathrm{CO}_{2}$ and $\mathrm{H}_{2} \mathrm{O}$.

Figures 5.17, 5.18 and 5.19 show the effect of the oxygen pressure on the acetic acid at $\mathrm{pH} 4$ and 220,240 and $260^{\circ} \mathrm{C}$, respectively. In all experiments, the same trend was observed, suggesting that acetic acid was produced at the beginning of the experiment, 
and as the reaction proceeded some of the acetic acid was degraded. It can also be seen that more acetic acid was produced at the higher oxygen pressure because the higher oxygen pressure resulted in higher dissolution of oxygen in the liquid phase. This enhanced the benzene degradation and resulted in the higher production of acids (See section 4.4.6).

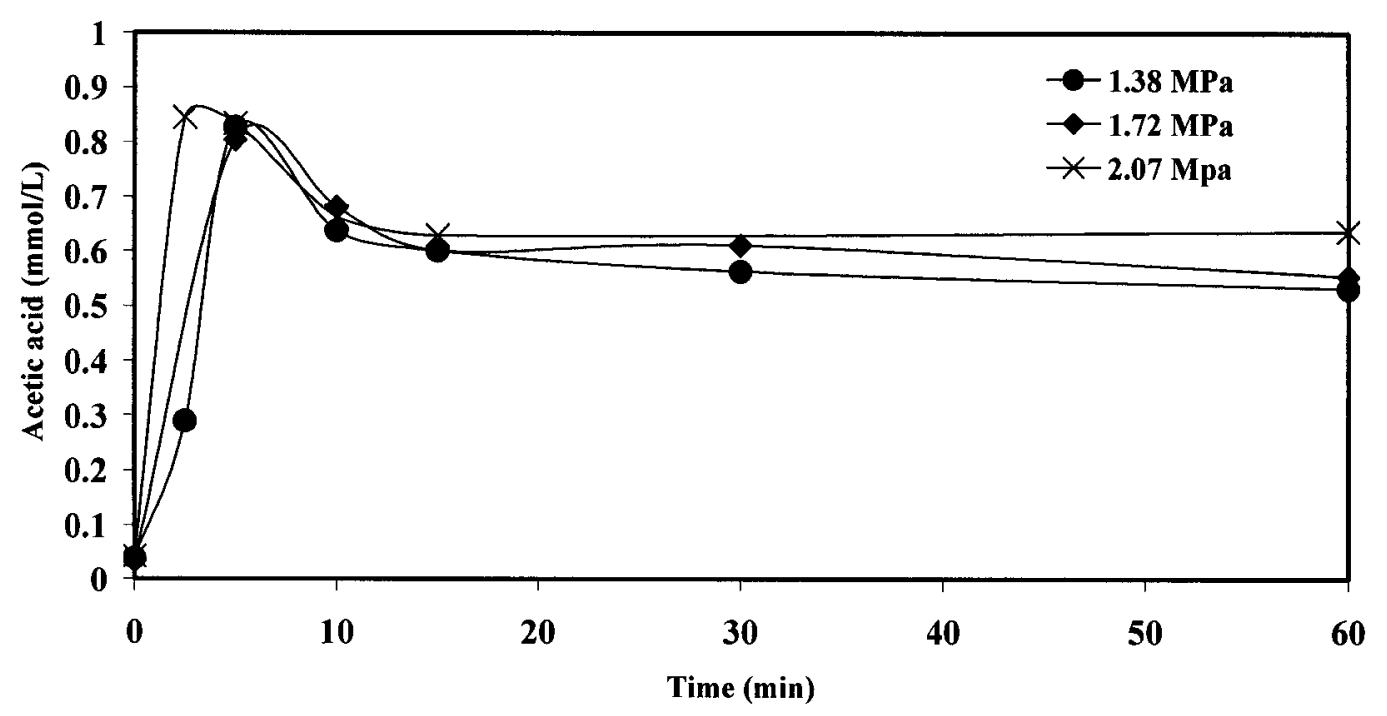

Figure 5.15: Effect of Pressure on Acetic Acid $\mathrm{T}=260^{\circ} \mathrm{C}, \mathrm{pH}=6$.

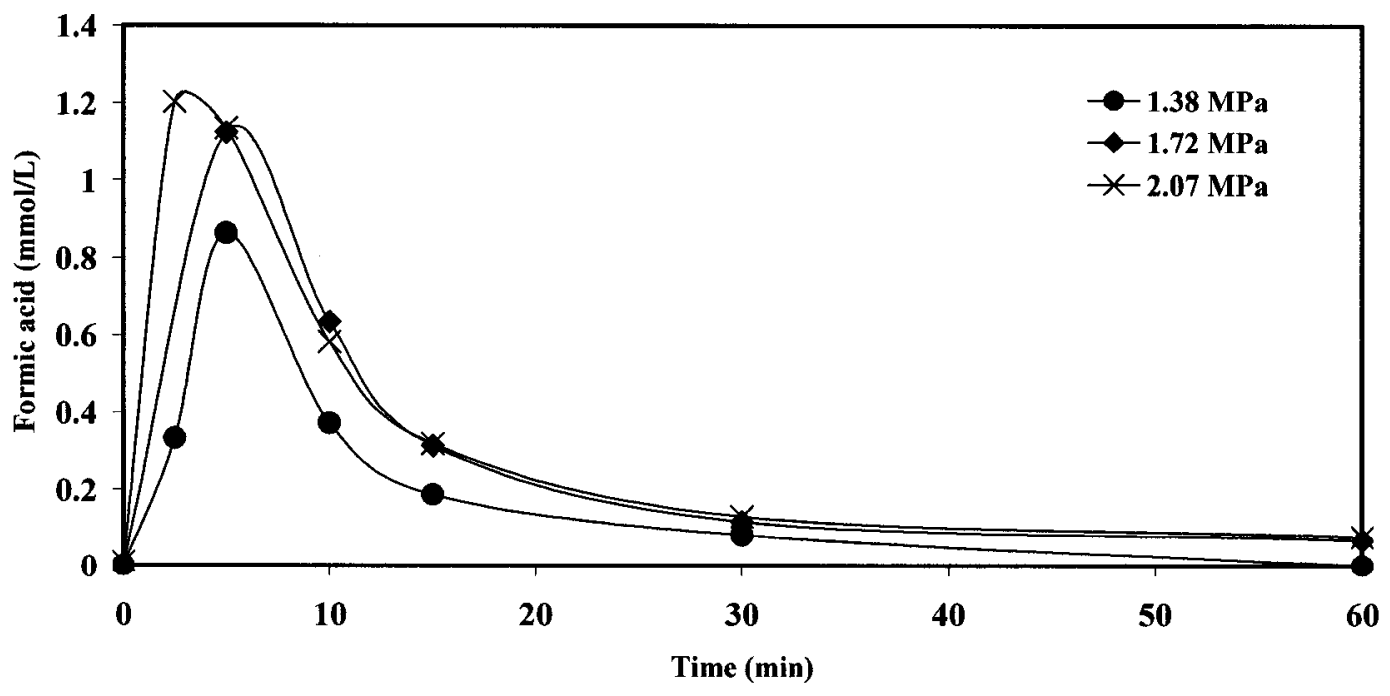

Figure 5.16: Effect of Pressure on Formic Acid, $\mathrm{T}=260^{\circ} \mathrm{C}, \mathrm{pH}=6$. 


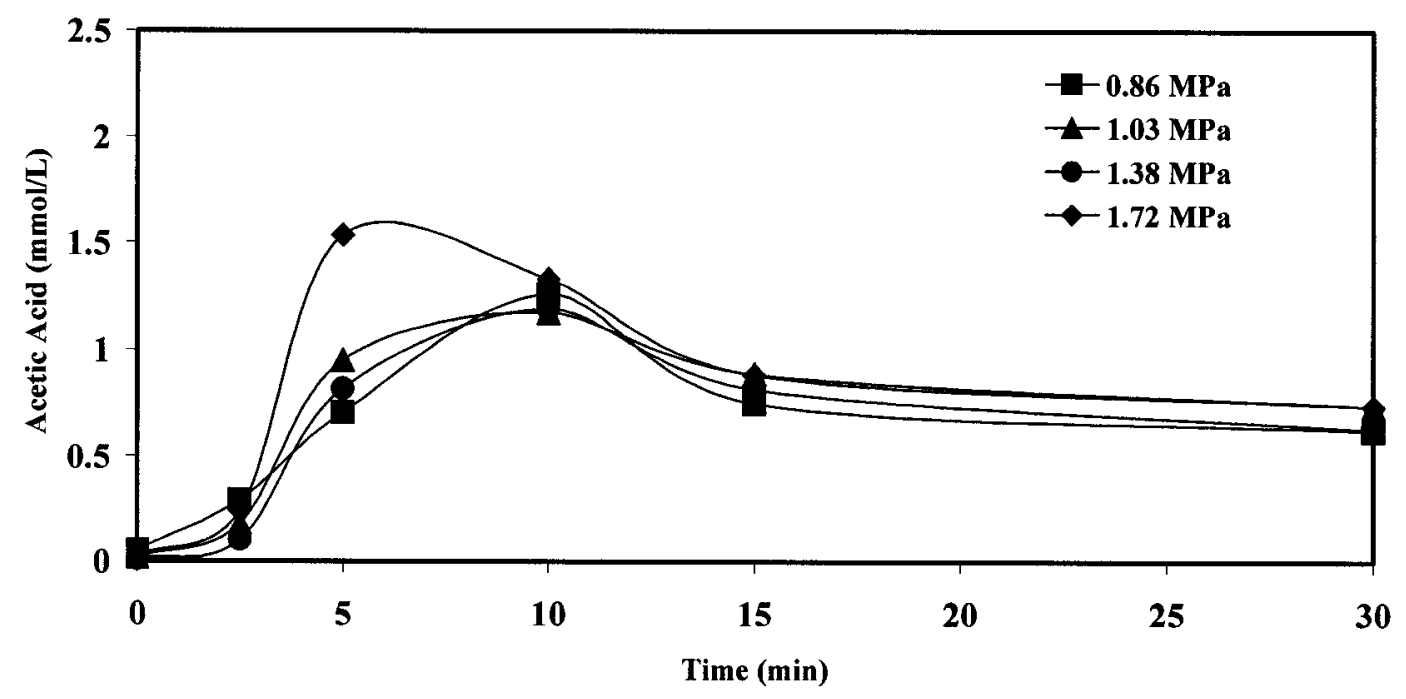

Figure 5.17: Effect of Pressure on Acetic Acid, $\mathrm{T}=220^{\circ} \mathrm{C}, \mathrm{pH}=4$.

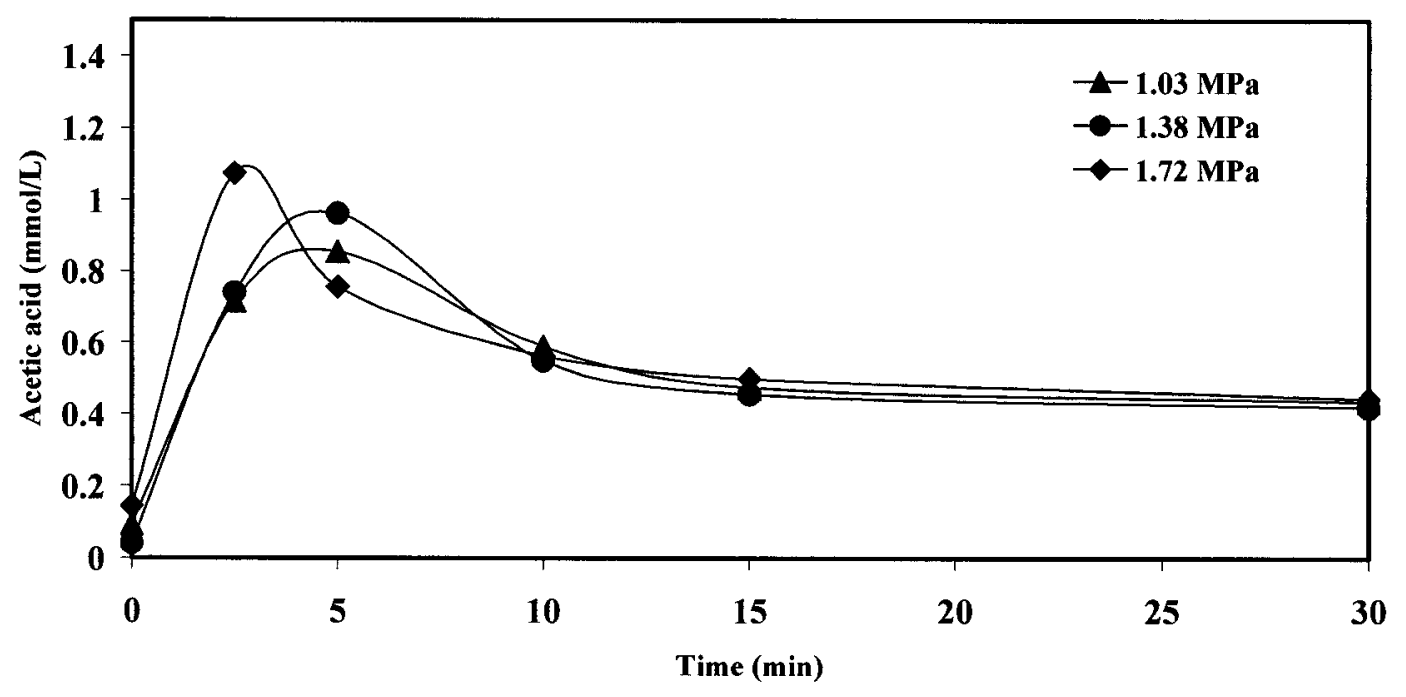

Figure 5.18: Effect of Pressure on Acetic Acid, $\mathrm{T}=240^{\circ} \mathrm{C}, \mathrm{pH}=4$. 


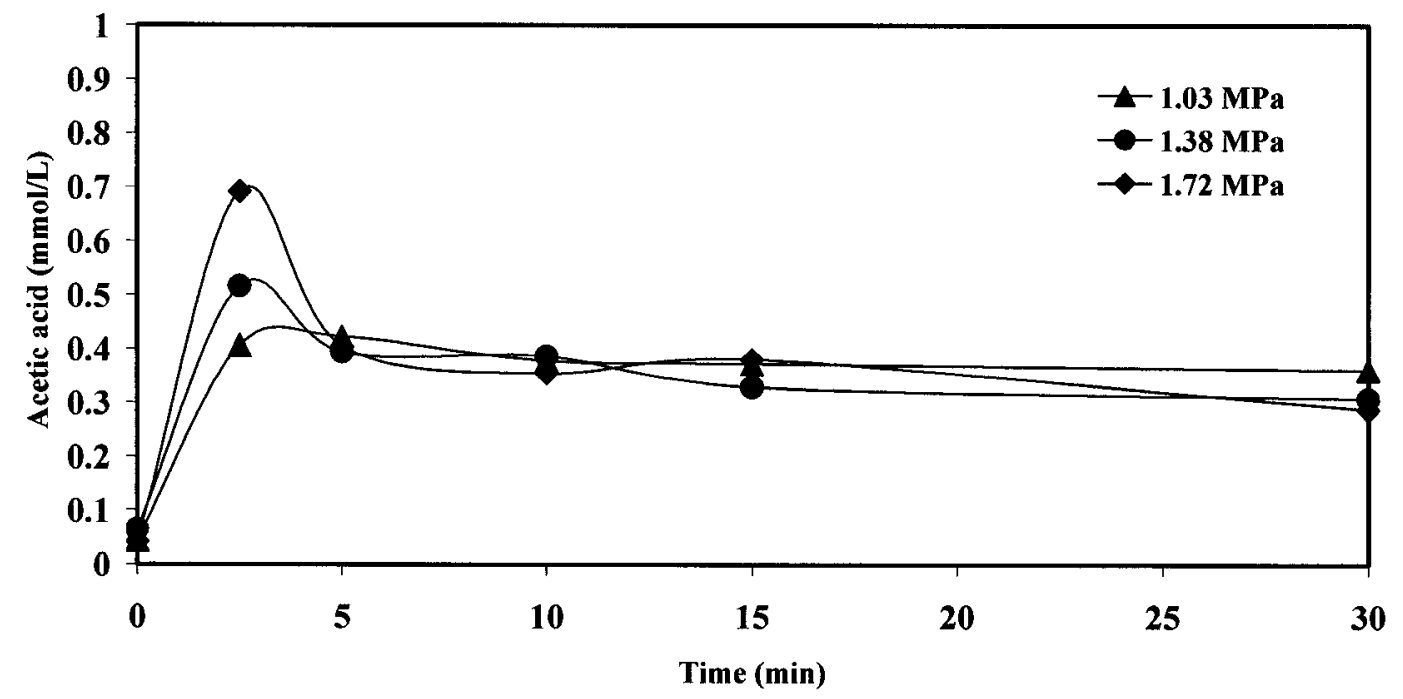

Figure 5.19: Effect of Pressure on Acetic Acid, $\mathrm{T}=260^{\circ} \mathrm{C}, \mathrm{pH}=4$.

Figures 5.20, 5.21 and 5.22 show the effect of the oxygen pressure on the formic acid formation at $\mathrm{pH} 4$ and 220,240 , and $260^{\circ} \mathrm{C}$, respectively. As the oxygen pressure increased more formic acid was produced. The degradation of the formic acid was faster at the higher oxygen pressure. At $240^{\circ} \mathrm{C}$, all of the formic acid produced during the reaction was degraded after 30 minutes, while at $260^{\circ} \mathrm{C}$ no formic acid was detected among the reaction products after 15 minutes at any given oxygen pressure. At $220^{\circ} \mathrm{C}$, only a small amount of the formic acid was detected after 30 minutes. 


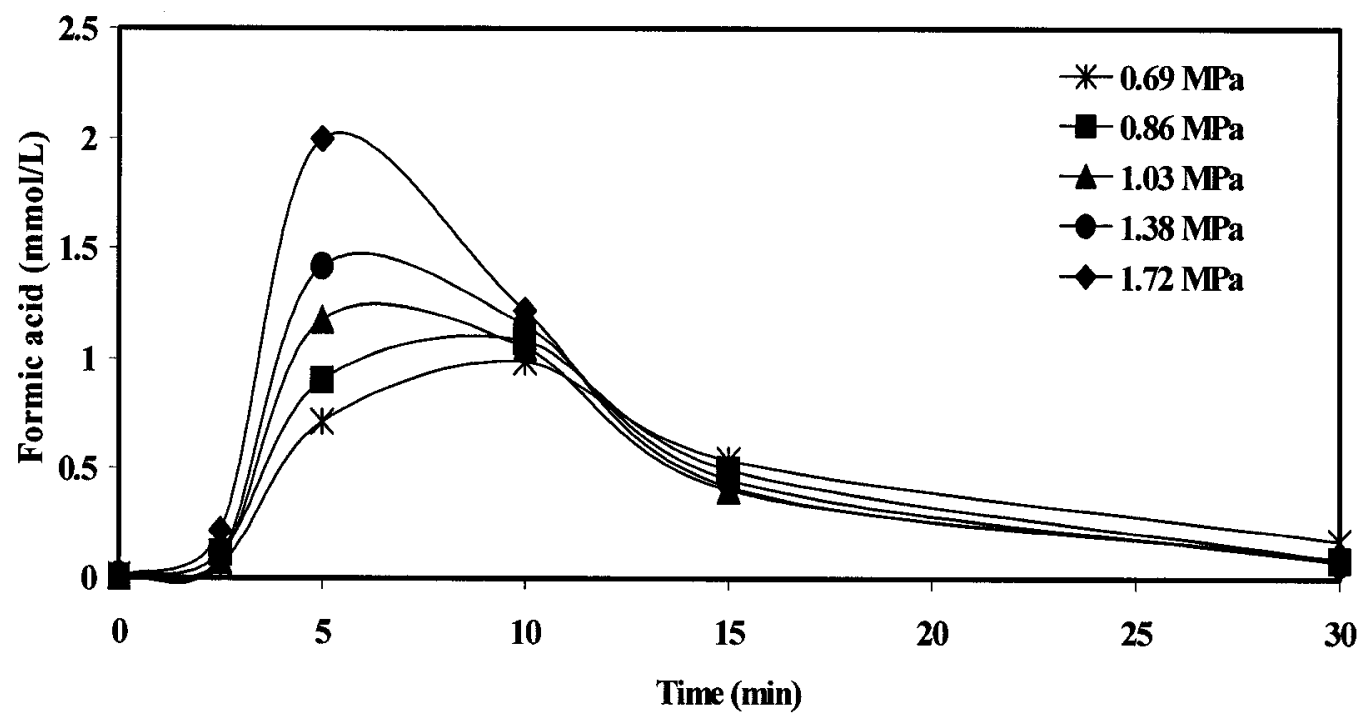

Figure 5.20: Effect of Pressure on Formic Acid, $\mathrm{T}=220^{\circ} \mathrm{C}, \mathrm{pH}=4$.

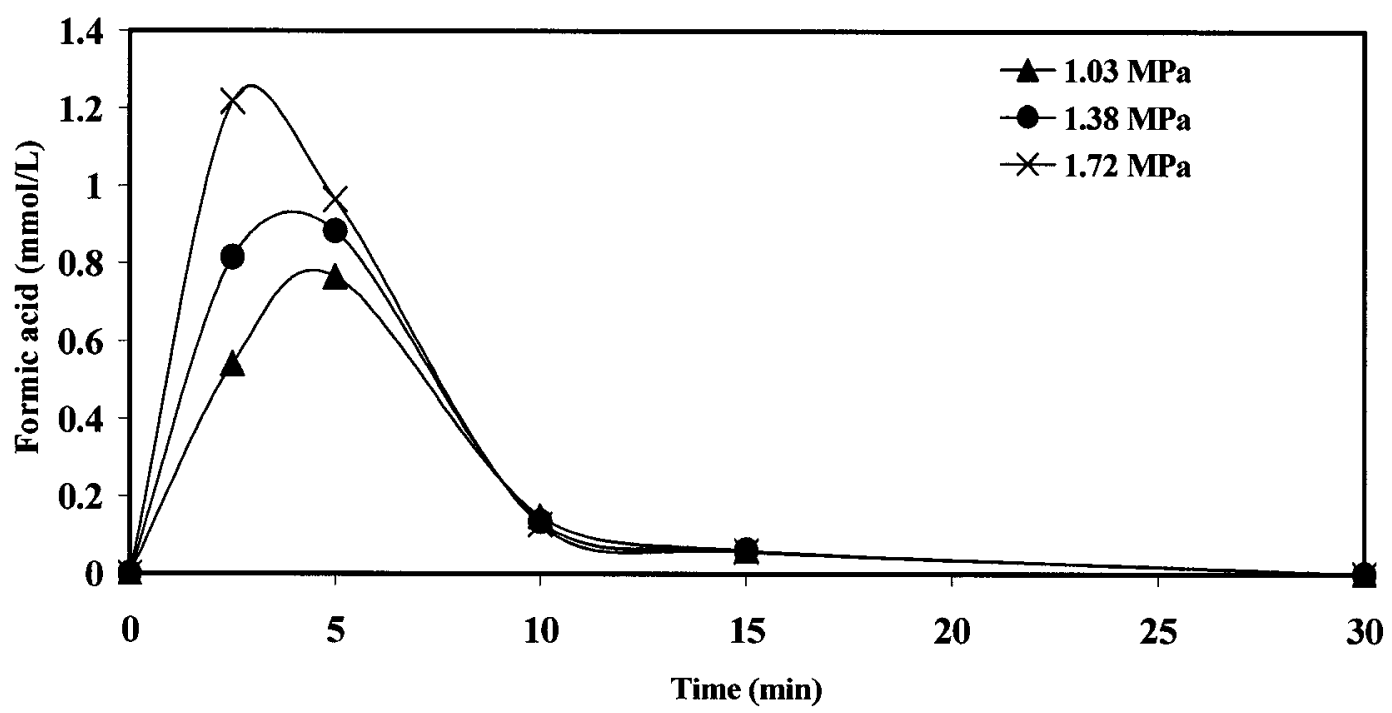

Figure 5.21: Effect of Pressure on Formic Acid, $\mathrm{T}=240^{\circ} \mathrm{C}, \mathrm{pH}=4$. 


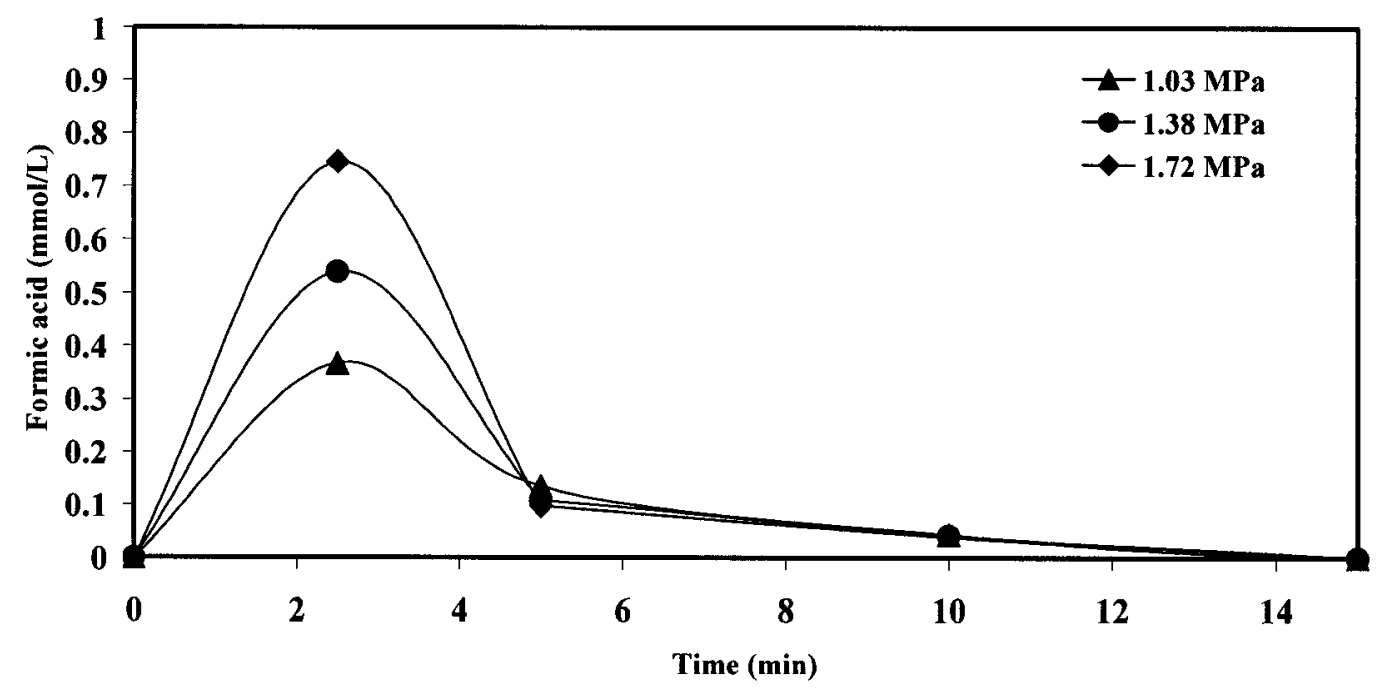

Figure 5.22: Effect of Pressure on Formic Acid, $\mathrm{T}=260^{\circ} \mathrm{C}, \mathrm{pH}=4$.

\subsection{Effect of pH on Acetic and Formic Acids}

As mentioned before, the initial $\mathrm{pH}$ of the reaction medium has a significant effect on the benzene oxidation; it affects both the production as well as the degradation of both the acetic and the formic acids, as is evident in Figures 5.23 and 5.24, respectively. The experiments were done at $220^{\circ} \mathrm{C}$ and $1.38 \mathrm{MPa}$. It should be mentioned that some of these results were obtained and reported before (Figures 5.11-5.14). At pH 6, the production of both acids started late because the oxidation of the benzene was slow. However, at lower $\mathrm{pH}$, the production of both acids started early. Also, more acids were produced at $\mathrm{pH} 5$ than that at $\mathrm{pH}$ 4. The main reason is that at the lower $\mathrm{pH}$ most of the benzene was oxidized to the final products (Section 4.4). Unlike $\mathrm{pH} 6$, faster degradation was achieved at both $\mathrm{pH} 4$ and $\mathrm{pH} 5$. At $240^{\circ} \mathrm{C}$, again higher concentrations of acids were produced at the lower $\mathrm{pH}$ and both the production and the degradation rates of the acids were faster at 
lower $\mathrm{pH}$, as seen in both Figures 5.25 and 5.26. Figures 5.27 and 5.28 show that lower $\mathrm{pH}$ produced faster rates than the higher $\mathrm{pH}$ at $260^{\circ} \mathrm{C}$. As it appears in the figures, considerably lower concentrations of acids were produced at $\mathrm{pH} 4$ than that at $\mathrm{pH} 6$. The formic acid was degraded appreciably faster at $\mathrm{pH} 4$. While no formic acid was noticed after 15 minutes at $\mathrm{pH} \mathrm{4}$, it took more than 30 minutes at $\mathrm{pH} 6$. The results show that higher temperatures and lower $\mathrm{pH}$ gave better results for both the production and the degradation of the acids. However, it should be noted that at the lower temperatures, slightly higher benzene oxidation was achieved after 30 minutes when larger amounts of acids were produced, thus further lowering the $\mathrm{pH}$ of the reaction medium (See Figures 4.17-4.19).

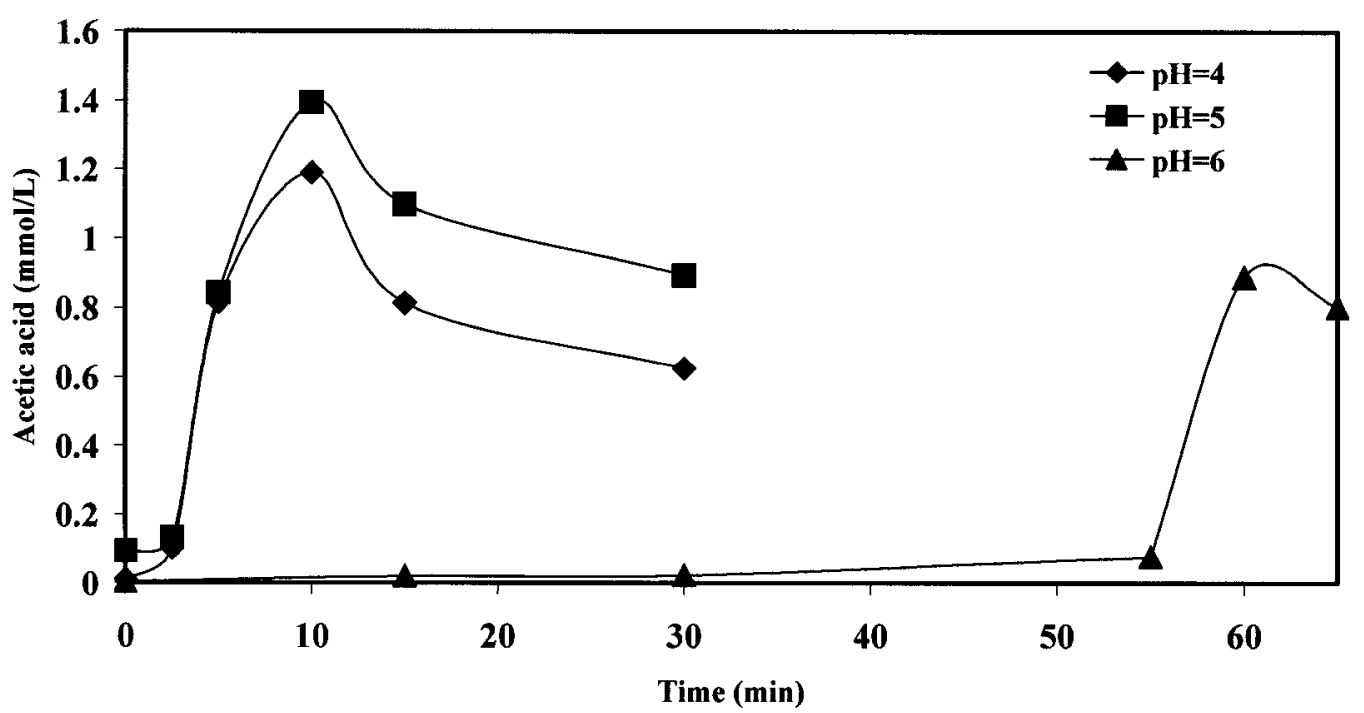

Figure 5.23: Effect of $\mathrm{pH}$ on Acetic Acid, $\mathrm{T}=220^{\circ} \mathrm{C}, \mathrm{pH}=4, \mathrm{P}_{\mathrm{O} 2}=1.38 \mathrm{MPa}$. 


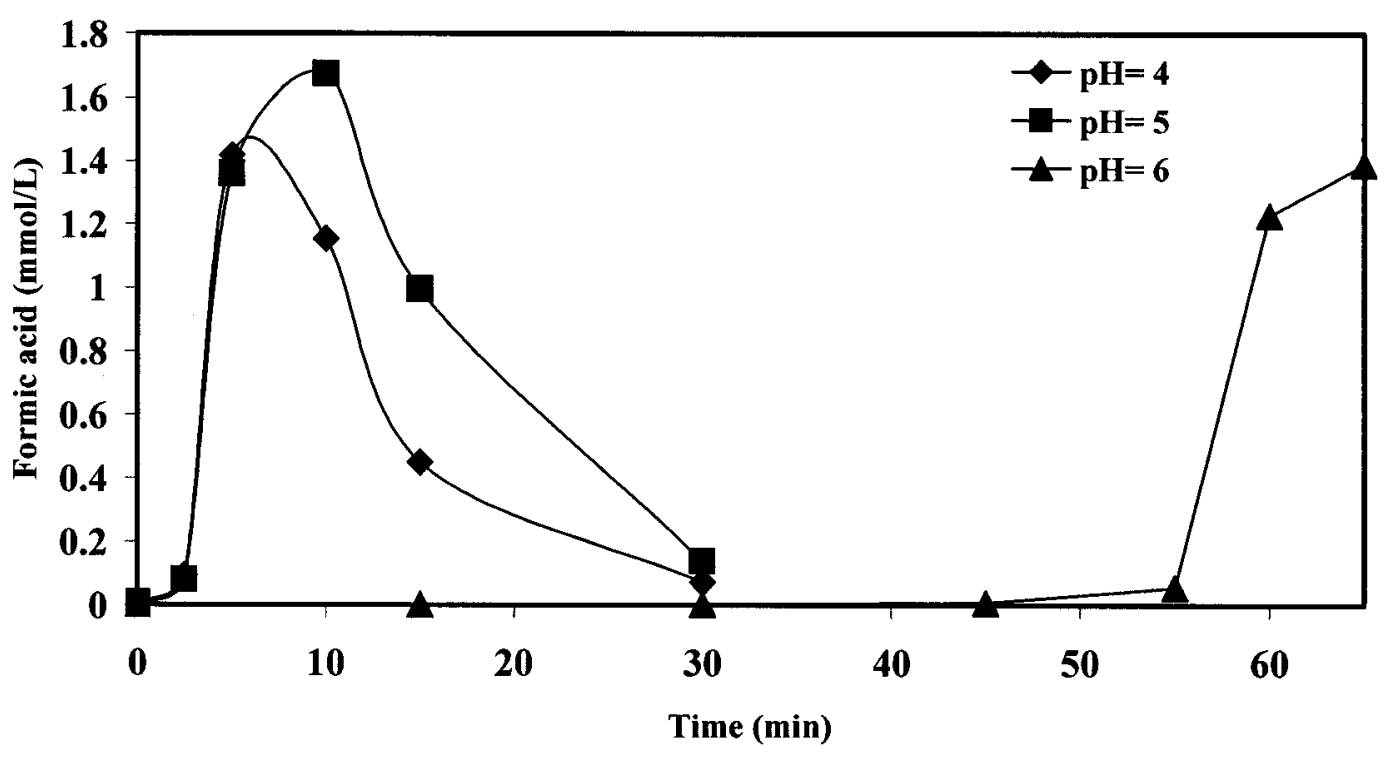

Figure 5.24: Effect of $\mathrm{pH}$ on Formic Acid, $\mathrm{T}=220^{\circ} \mathrm{C}, \mathrm{pH}=4, \mathrm{P}_{\mathrm{O} 2}=1.38 \mathrm{MPa}$.

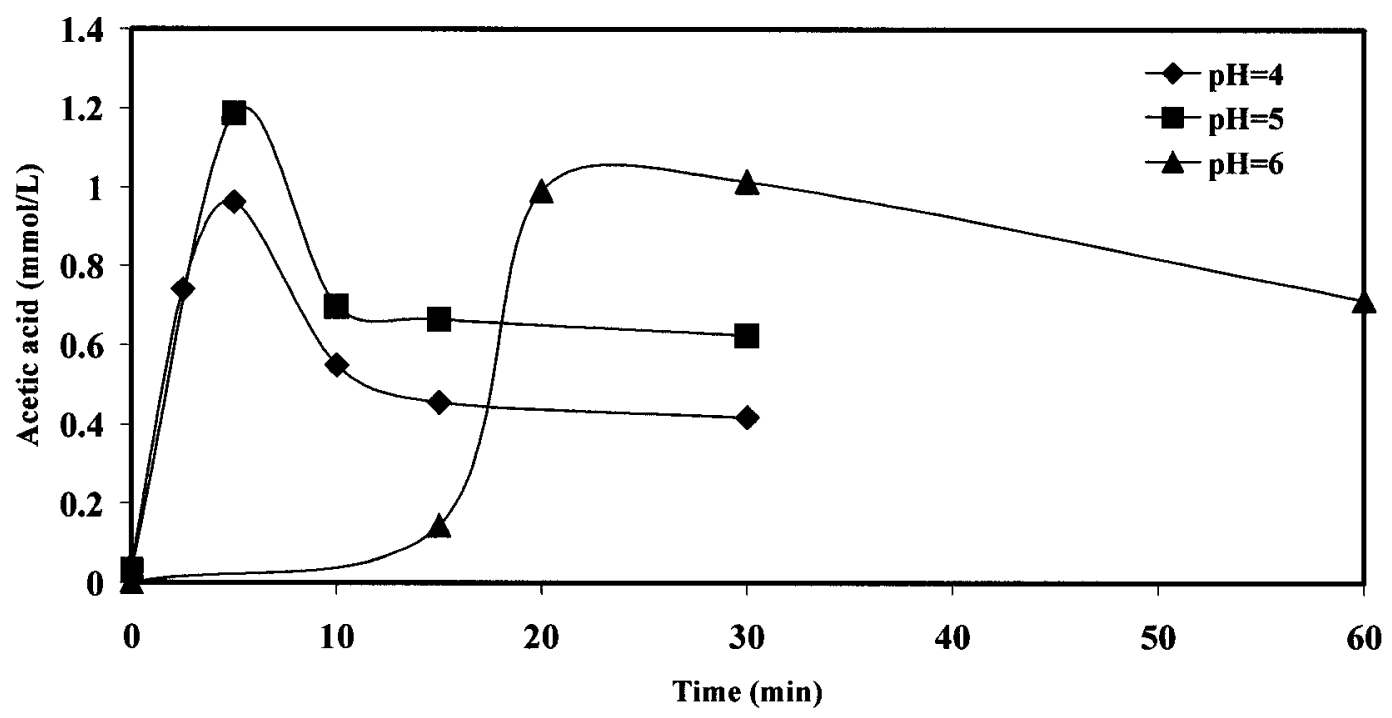

Figure 5.25: Effect of $\mathrm{pH}$ on Acetic Acid, $\mathrm{T}=240^{\circ} \mathrm{C}, \mathrm{pH}=4, \mathrm{P}_{\mathrm{O} 2}=1.38 \mathrm{MPa}$. 


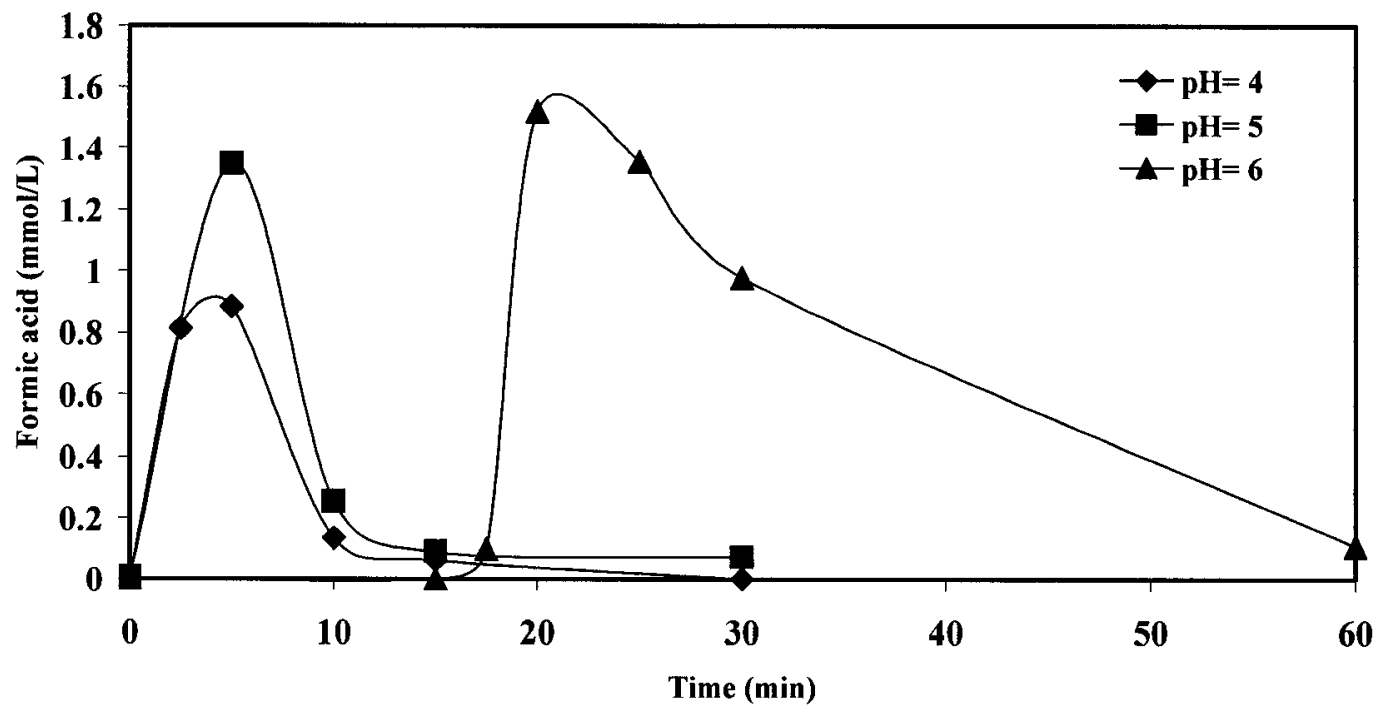

Figure 5.26: Effect of $\mathrm{pH}$ on Formic Acid, $\mathrm{T}=240^{\circ} \mathrm{C}, \mathrm{pH}=4, \mathrm{P}_{\mathrm{O} 2}=1.38 \mathrm{MPa}$.

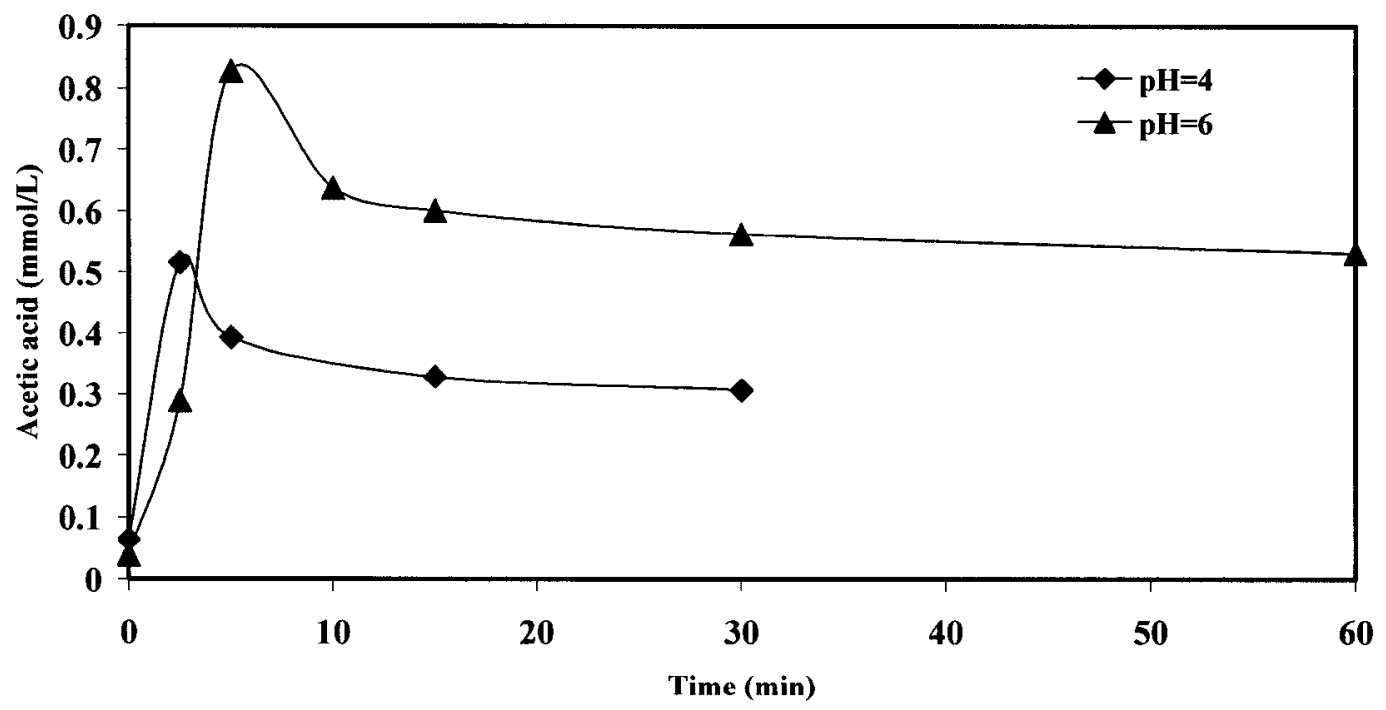

Figure 5.27: Effect of $\mathrm{pH}$ on Acetic Acid, $\mathrm{T}=260^{\circ} \mathrm{C}, \mathrm{pH}=4, \mathrm{P}_{\mathrm{O} 2}=1.38 \mathrm{MPa}$. 


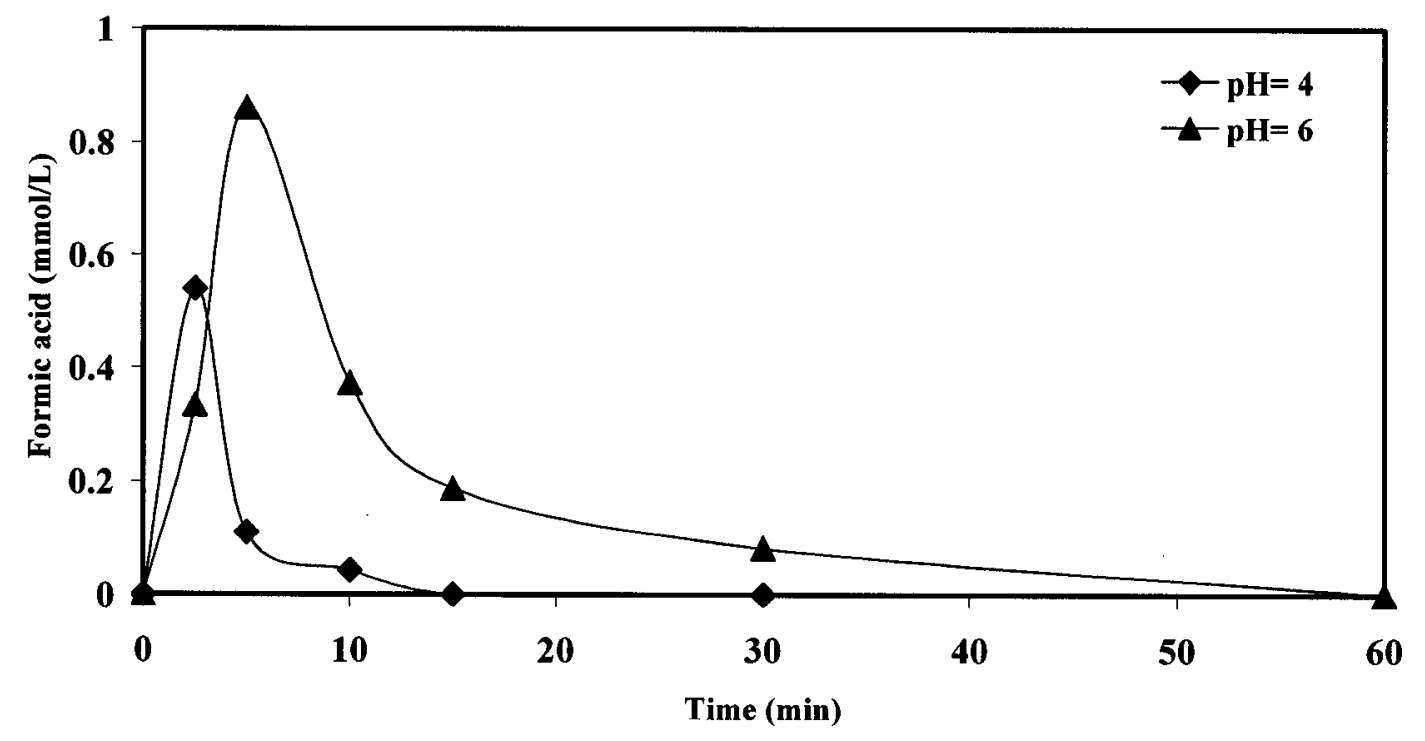

Figure 5.28: Effect of $\mathrm{pH}$ on Formic Acid, $\mathrm{T}=260^{\circ} \mathrm{C}, \mathrm{pH}=4, \mathrm{P}_{\mathrm{O} 2}=1.38 \mathrm{MPa}$.

\subsubsection{Effect of Acidification Methods on the Intermediates}

As mentioned before, nitric acid was usually used to lower the $\mathrm{pH}$. However, sulfuric acid was also tried in order to find out whether the anion would have any effect on the process. The results shows that the same trend has been obtained for both acetic acid and formic acid, which means that the type of acid did not have any impact on the results, as long as the initial $\mathrm{pH}$ was similar (Figures 5.29 and 5.30). The difference in the amount of acids can be attributed to the slightly different initial amount of the benzene used in the experiments. 


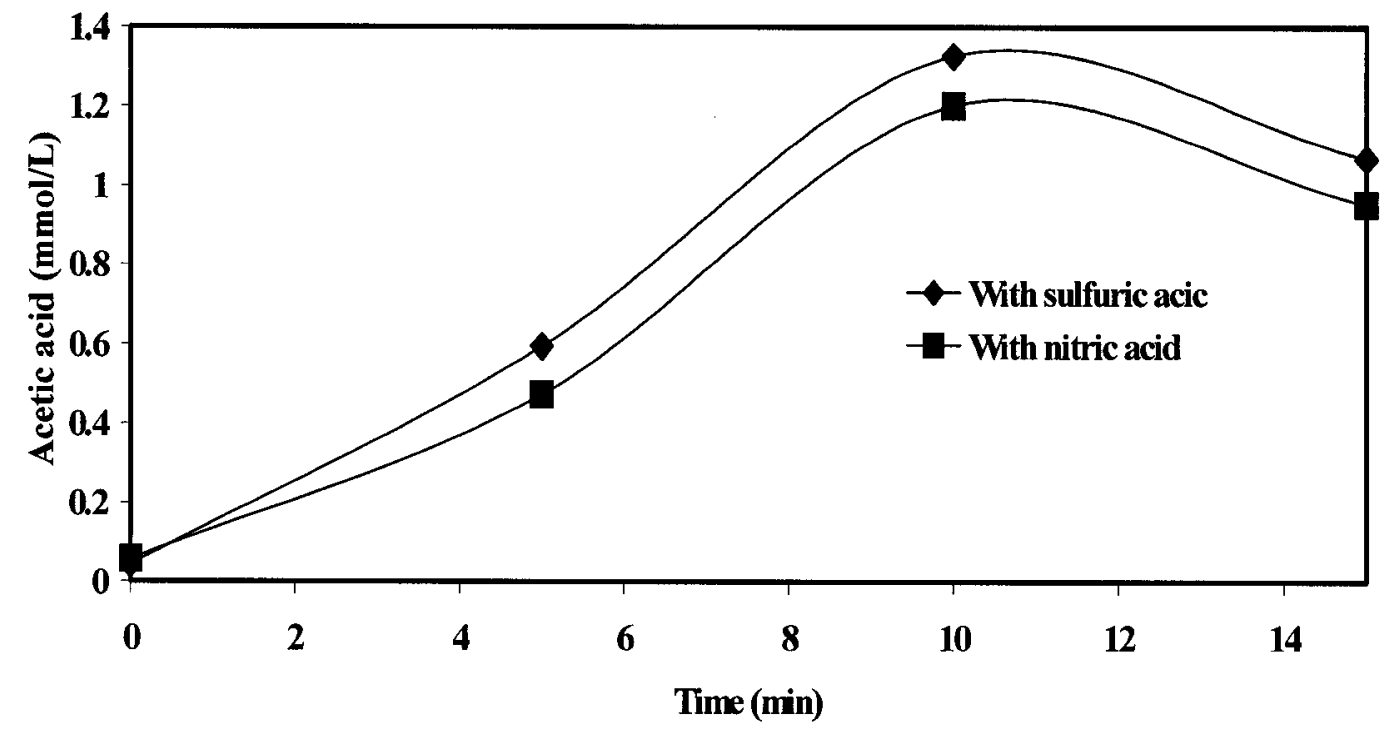

Figure 5.29: Effect of Acidification Methods on Acetic Acid, $\mathrm{T}=220^{\circ} \mathrm{C}, \mathrm{P}_{\mathrm{O} 2}=1.38 \mathrm{MPa}$, $\mathrm{pH}=4$.

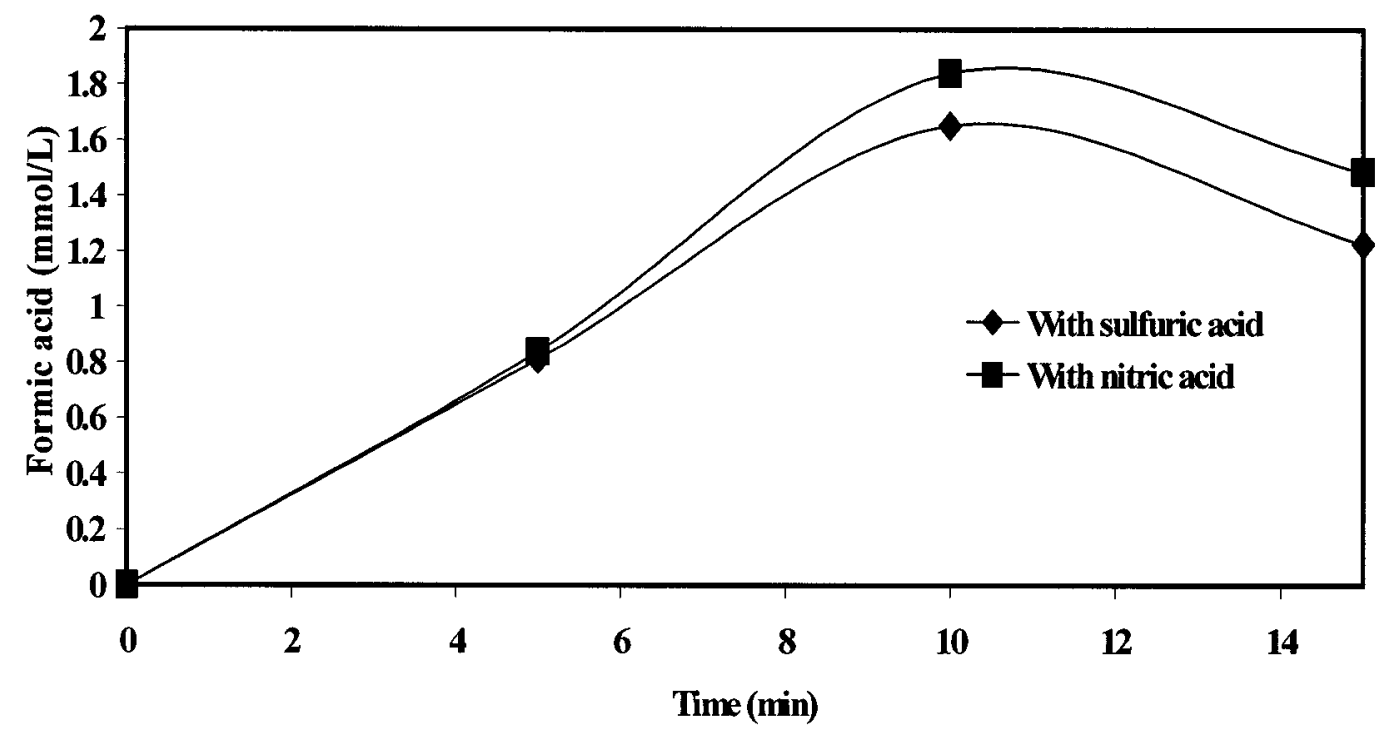

Figure 5.30: Effect of Acidification Methods on Formic Acid, $\mathrm{T}=220^{\circ} \mathrm{C}, \mathrm{P}_{\mathrm{O} 2}=1.38 \mathrm{MPa}$, $\mathrm{pH}=4$. 


\subsection{Effect of Initial Benzene Concentration on Both Acetic and Formic Acids}

Two experiments were done at $\mathrm{pH} 4$ with an initial benzene concentration of 11.25 $\mathrm{mmol} / \mathrm{L}$, which was double the amount that was typically used in this study (See section 4.5). The initial oxygen pressure was set to be $2.76 \mathrm{MPa}$. From the Figures 5.31 and 5.32 for acetic and formic acids, respectively, it is apparent that the higher amount of acids was produced when compared with results obtained from lower initial amount of benzene (See Figures 5.12 and 5.14). Since the oxidation of benzene was faster at $240^{\circ} \mathrm{C}$ the production of both acids started faster at this temperature. More acids were produced at $220^{\circ} \mathrm{C}$ than $240^{\circ} \mathrm{C}$ and no formic acid was noticed after 15 minutes at $240^{\circ} \mathrm{C}$. At both temperatures, acetic acid was preserved as a final product.

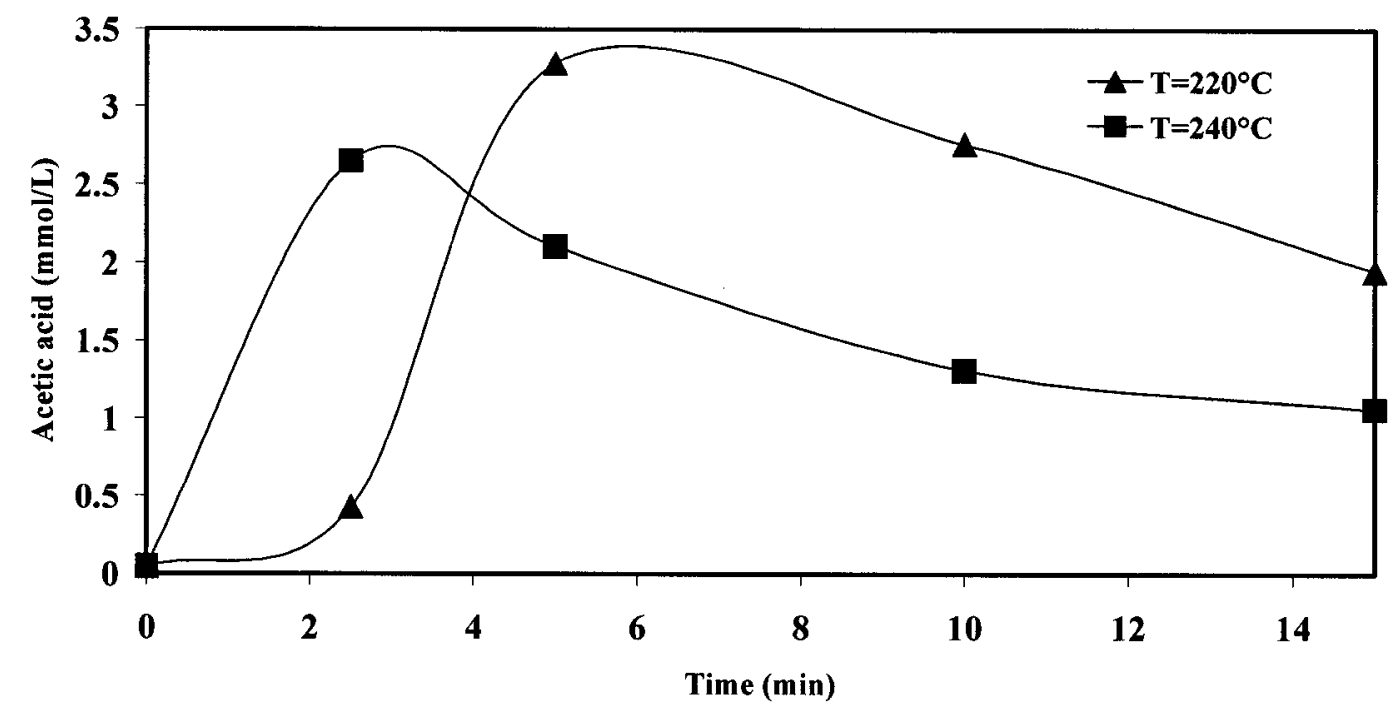

Figure 5.31: Effect of Temperature on Acetic Acid, $\mathrm{P}_{\mathrm{O} 2}=2.76 \mathrm{MPa}, \mathrm{pH}=4$, Initial Benzene Concentration $=11.25 \mathrm{mmol} / \mathrm{L}$. 


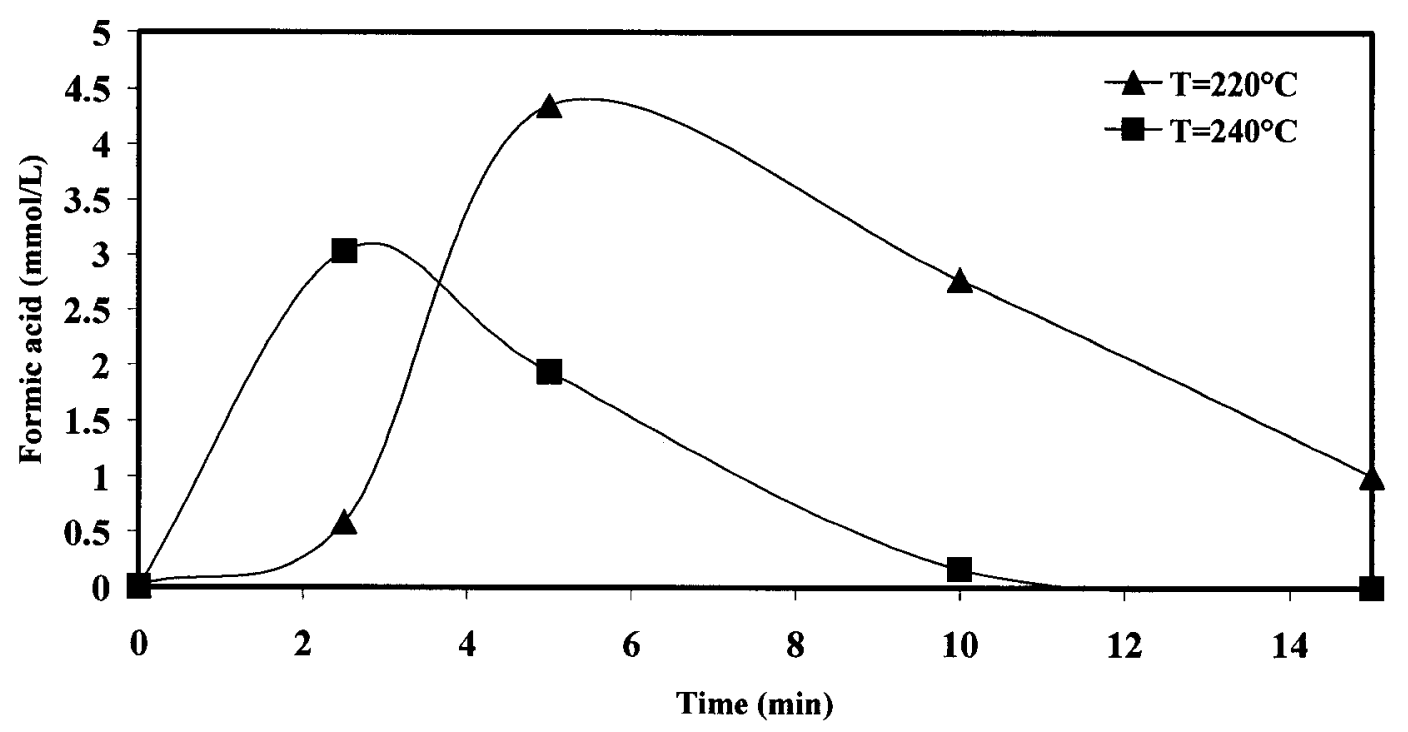

Figure 5.32: Effect of Temperature on Formic Acid, $\mathrm{P}_{\mathrm{O} 2}=2.76 \mathrm{MPa}, \mathrm{pH}=4$. Initial Benzene Concentration $=11.25 \mathrm{mmol} / \mathrm{L}$.

\subsection{Wet Air Oxidation of Both Acetic and Formic Acids}

The wet air oxidation of both the acetic and formic acids was studied in order to determine what will happen if they exist alone in the effluent. The wet air oxidation of acetic acid was studied at $260^{\circ} \mathrm{C}$ and oxygen pressure of $2.07 \mathrm{MPa}$, which were the extreme conditions used in this study. It was found that at these conditions no degradation was achieved (Figure 5.33). A comparison of this result with those shown in Figure 5.12 shows that the presence of other organic compounds (such as unreacted benzene and formic acid) enhanced the degradation of acetic acid. This phenomenon is widely observed in WAO and is the subject of the next chapter.

The wet air oxidation for formic acid was studied at both $260^{\circ} \mathrm{C}$ and oxygen pressure of $2.07 \mathrm{MPa}$ and at $220^{\circ} \mathrm{C}$ and oxygen pressure of $1.38 \mathrm{MPa}$. In both experiments, almost all of the formic acid disappeared before the addition of the oxygen (Table 5.2), which 
suggests that decomposition of the formic acid took place either by decarbonylation or decarboxylation [73].

$$
\begin{aligned}
& \mathrm{HCOOH} \longleftrightarrow \mathrm{CO}+\mathrm{H}_{2} \mathrm{O} \quad \text { (Decarbonylation) } \\
& \mathrm{HCOOH} \longleftrightarrow \mathrm{CO}_{2}+\mathrm{H}_{2} \quad \text { (Decarboxylation) }
\end{aligned}
$$

Furthermore, an experiment was done with formic acid, in which samples were collected every 10 minutes in the heating up period. In this experiment no oxygen was added. The results (Table 5.3) show that the concentration of formic acid started to drop when the temperature reached around $193^{\circ} \mathrm{C}$ and after that it decreased even faster. At around $227^{\circ} \mathrm{C}$, most of the formic acid disappeared. This suggests that at certain temperature and in the absence of oxygen the formic acid starts to decompose as mentioned above.

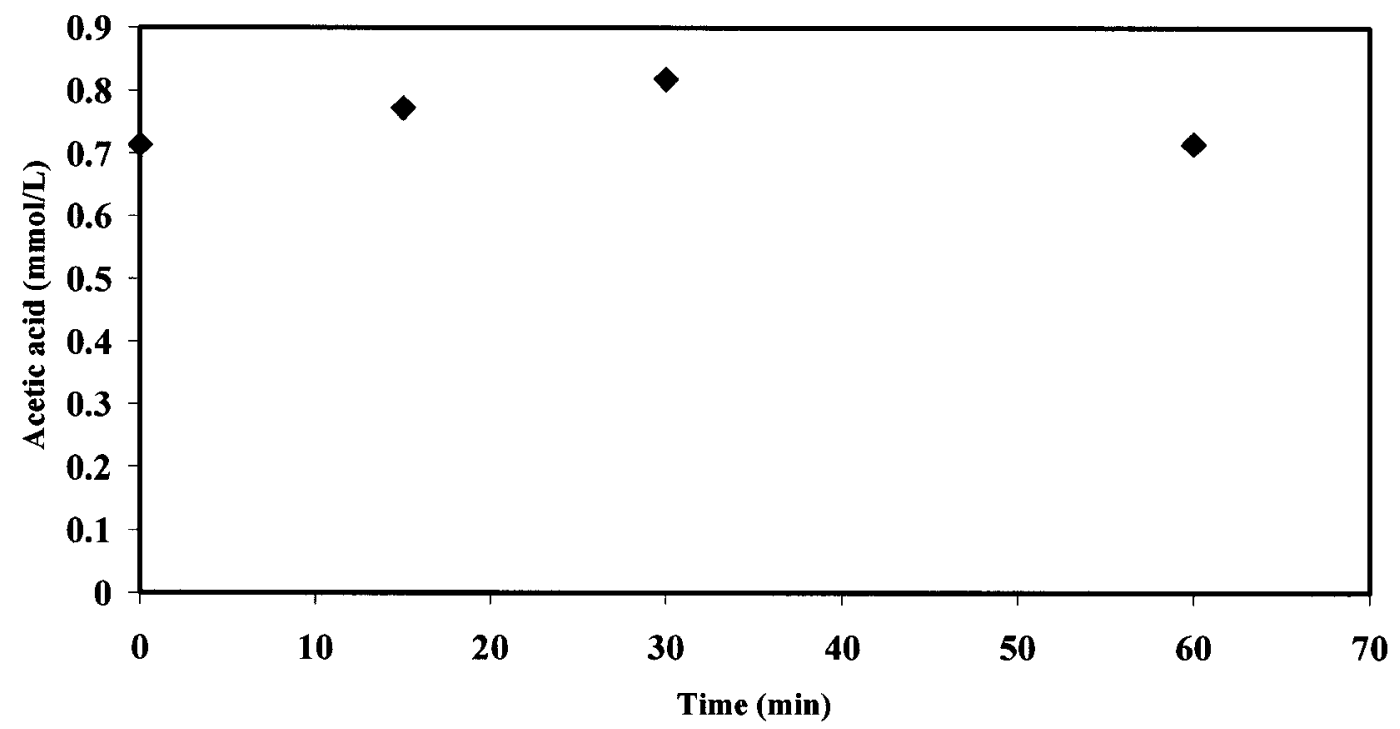

Figure 5.33: Degradation of Acetic Acid, $\mathrm{T}=260^{\circ} \mathrm{C}, \mathrm{P}_{\mathrm{O} 2}=2.07 \mathrm{MPa}$. 
Table 5.2: Effect of Temperature on Formic Acid.

\begin{tabular}{|c|c|c||}
\hline $\begin{array}{c}\text { Time } \\
(\mathrm{min})\end{array}$ & $\begin{array}{c}\text { mmol Formic Acid } \\
\left(220^{\circ} \mathrm{C}, \mathrm{P}_{\mathrm{O} 2}=1.38 \mathrm{MPa}\right)\end{array}$ & $\begin{array}{c}\text { mmol Formic Acid } \\
\left(260^{\circ} \mathrm{C}, \mathrm{P}_{\mathrm{O} 2}=2.07 \mathrm{MPa}\right)\end{array}$ \\
\hline Original Sample & 2.1 & 2.1 \\
\hline 0 & 0.1 & 0 \\
\hline 15 & 0 & 0 \\
\hline
\end{tabular}

Table 5.3: Concentration of Formic Acid at Different Temperatures.

\begin{tabular}{||c|c|c|c||}
\hline \hline Time $(\mathrm{min})$ & Temperature $\left({ }^{\circ} \mathrm{C}\right)$ & Total pressure (MPa) & mmol Formic acid/L \\
\hline 0 & 17 & 0.20 & 1.97 \\
\hline 10 & 21 & 0.19 & 2.03 \\
\hline 20 & 32 & 0.19 & 2.04 \\
\hline 30 & 49 & 0.20 & 2.10 \\
\hline 40 & 68 & 0.23 & 1.92 \\
\hline 50 & 88 & 0.28 & 1.96 \\
\hline 60 & 109 & 0.37 & 2.01 \\
\hline 70 & 132 & 0.52 & 2.06 \\
\hline 80 & 153 & 0.78 & 2.03 \\
\hline 90 & 173 & 1.15 & 1.91 \\
\hline 100 & 193 & 1.65 & 1.76 \\
\hline 110 & 211 & 2.27 & 0.84 \\
\hline 120 & 227 & 3.03 & 0.06 \\
\hline 130 & 241 & 3.86 & 0.01 \\
\hline 150 & 257 & 4.90 & 0.00 \\
\hline
\end{tabular}

\subsection{Repeatability of the Results}

Since the initial benzene concentration was not exactly the same for the replicates it was expected not to have exactly the same results. The results that were obtained for replicates for acetic acid can be seen in figures 5.34, 5.35 and 5.36 while those for formic 
acid can be seen in figures $5.37,5.38$ and 5.39 both at 220,240 and $260^{\circ} \mathrm{C}$, respectively. These figures show that the trend in all experiment were comparable.

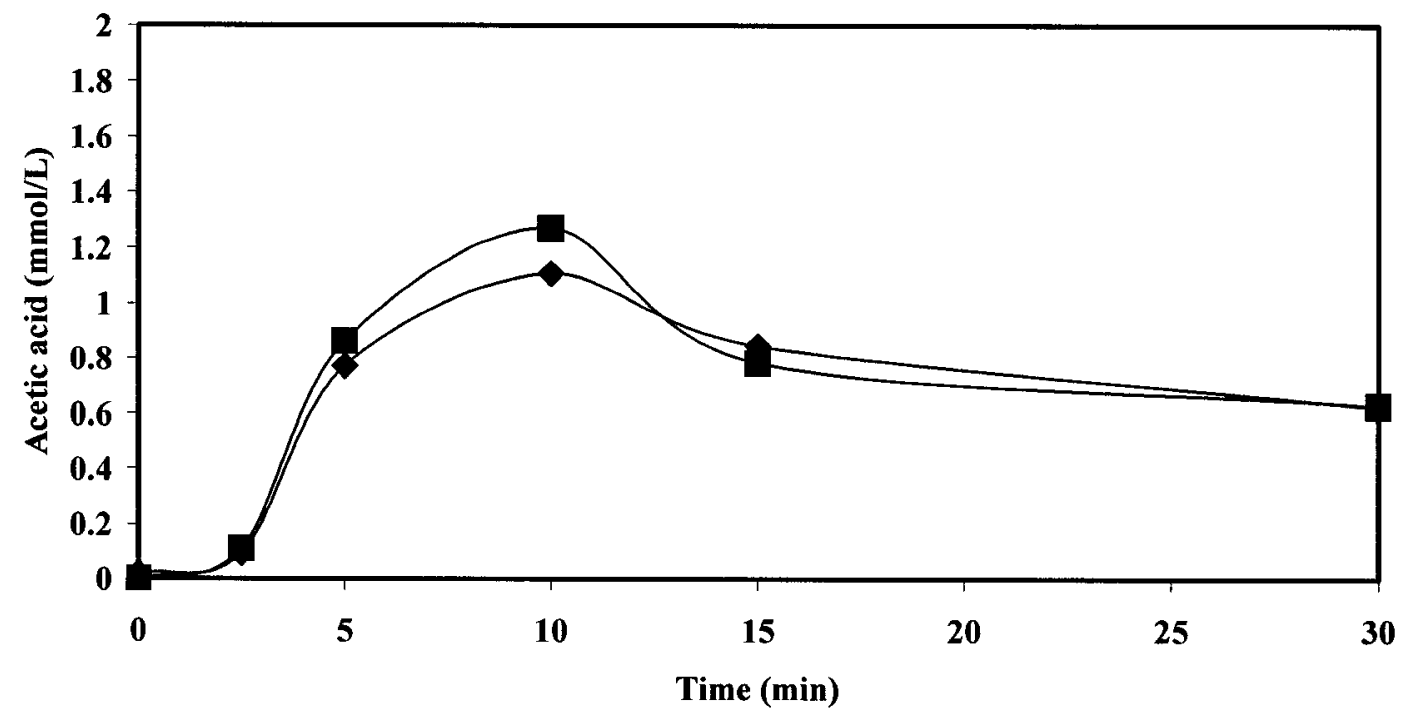

Figure 5.34: Acetic acid profile for replicates, $\mathrm{T}=220^{\circ} \mathrm{C}, \mathrm{P}_{\mathrm{O} 2}, 1.38 \mathrm{MPa}, \mathrm{pH}=4$.

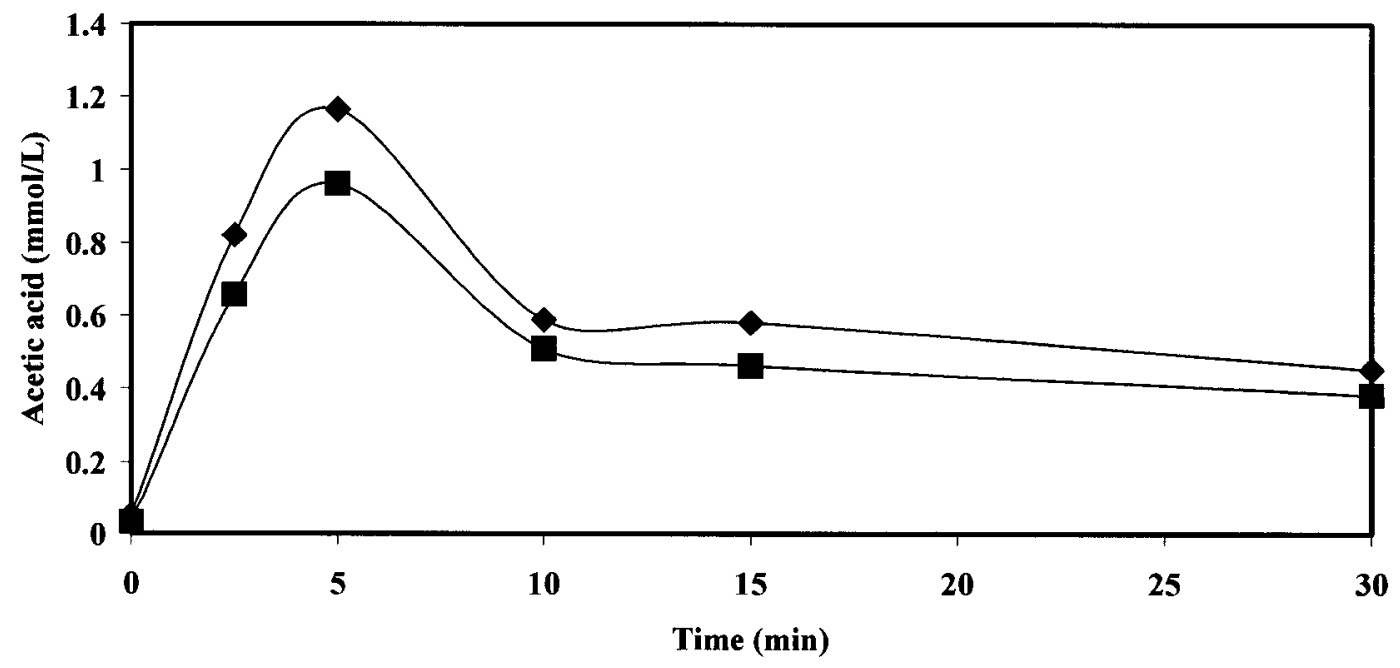

Figure 5.35: Acetic acid profile for replicates, $\mathrm{T}=240^{\circ} \mathrm{C}, \mathrm{P}_{\mathrm{O} 2}, 1.38 \mathrm{MPa}, \mathrm{pH}=4$. 


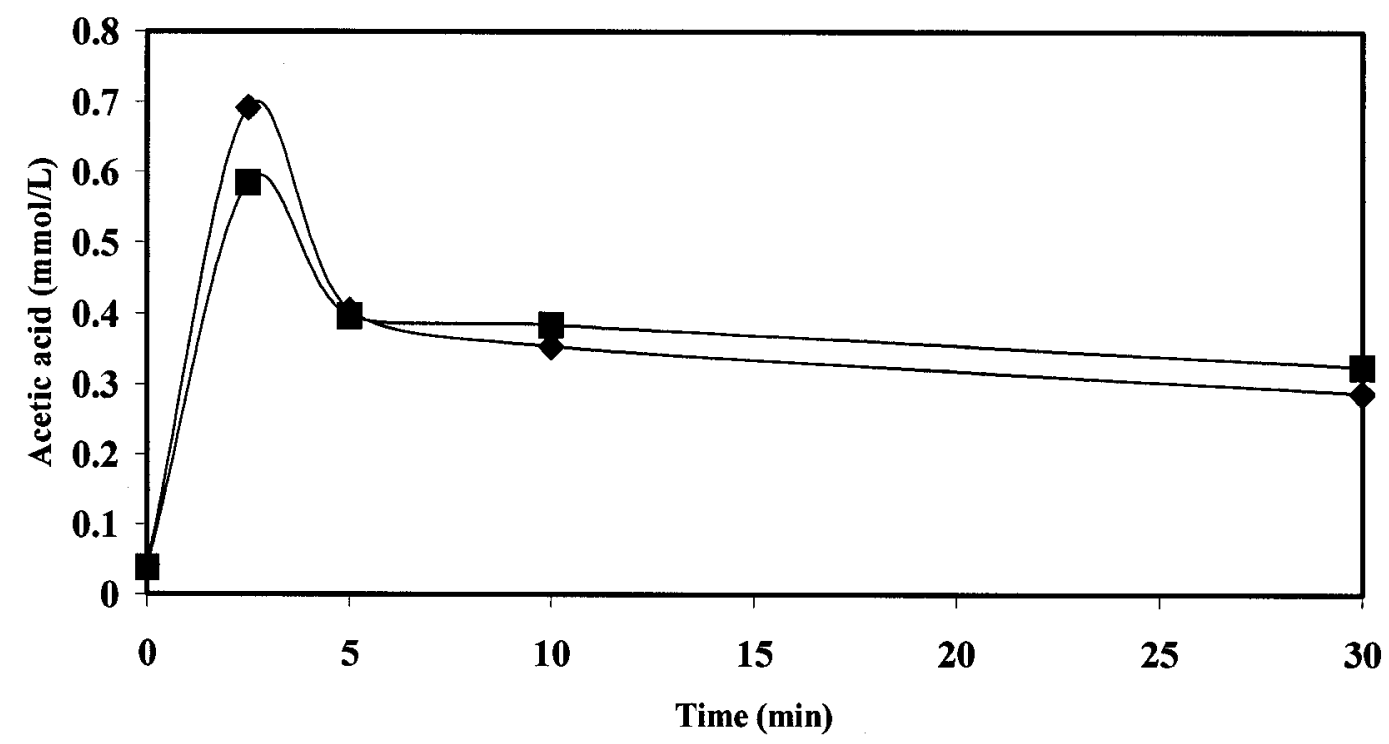

Figure 5.36: Acetic acid profile for replicates, $\mathrm{T}=260^{\circ} \mathrm{C}, \mathrm{P}_{\mathrm{O} 2}, 1.72 \mathrm{MPa}, \mathrm{pH}=4$.

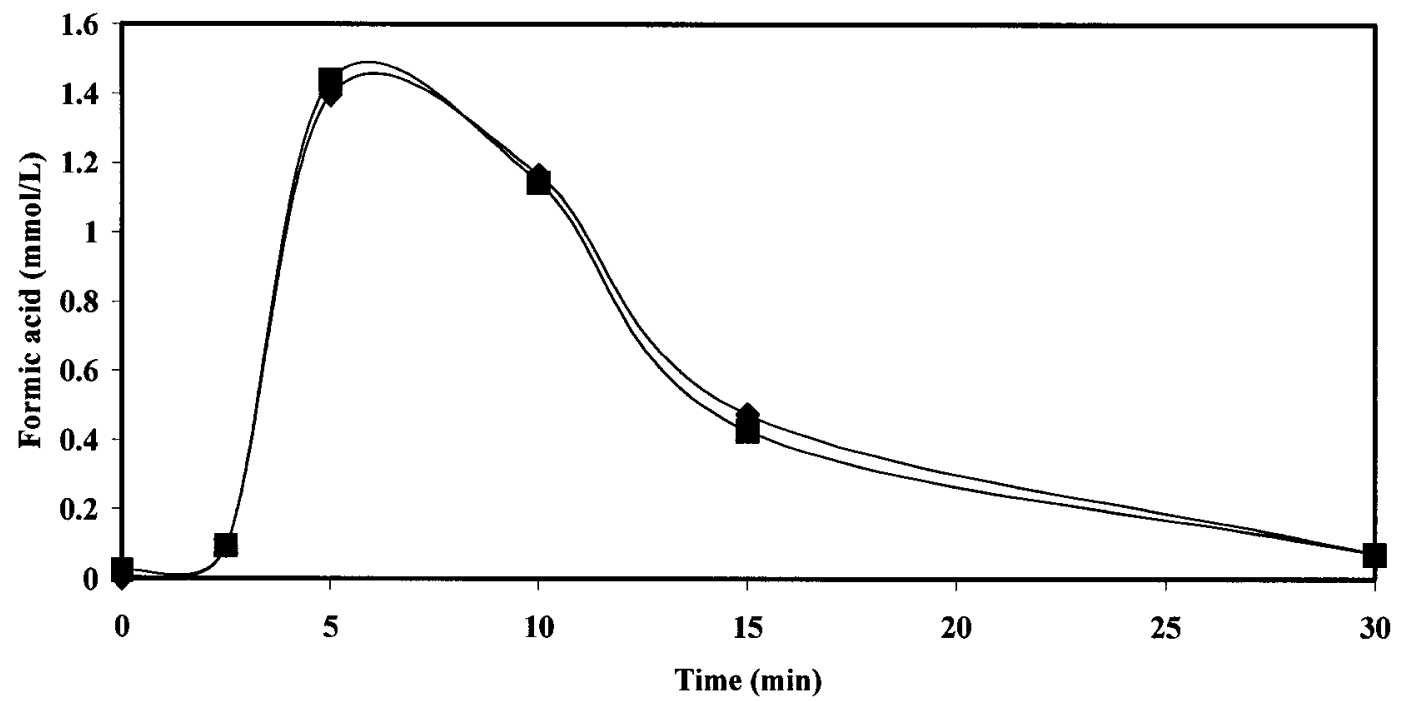

Figure 5.37: Formic acid profile for replicates, $\mathrm{T}=220^{\circ} \mathrm{C}, \mathrm{P}_{\mathrm{O} 2}, 1.38 \mathrm{MPa}, \mathrm{pH}=4$. 


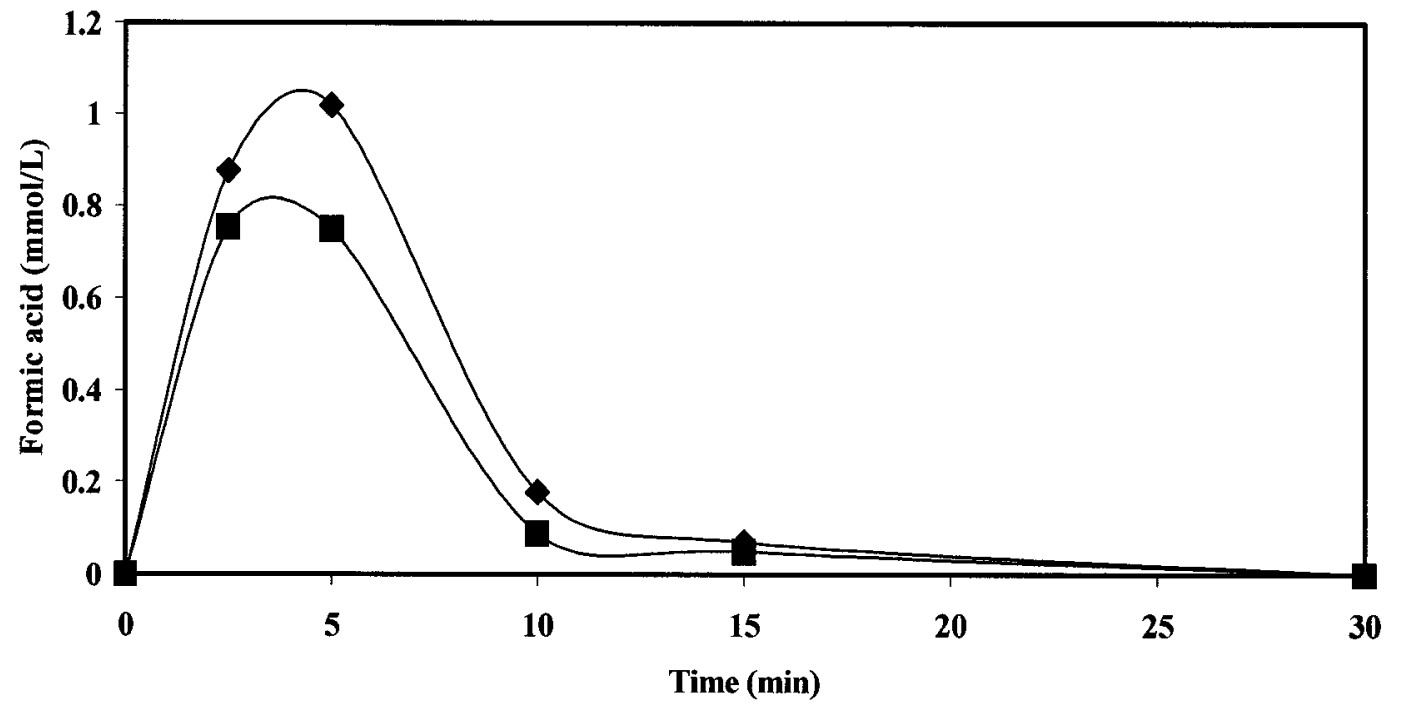

Figure 5.38: Formic acid profile for replicates, $\mathrm{T}=240^{\circ} \mathrm{C}, \mathrm{P}_{\mathrm{O} 2}, 1.38 \mathrm{MPa}, \mathrm{pH}=4$.

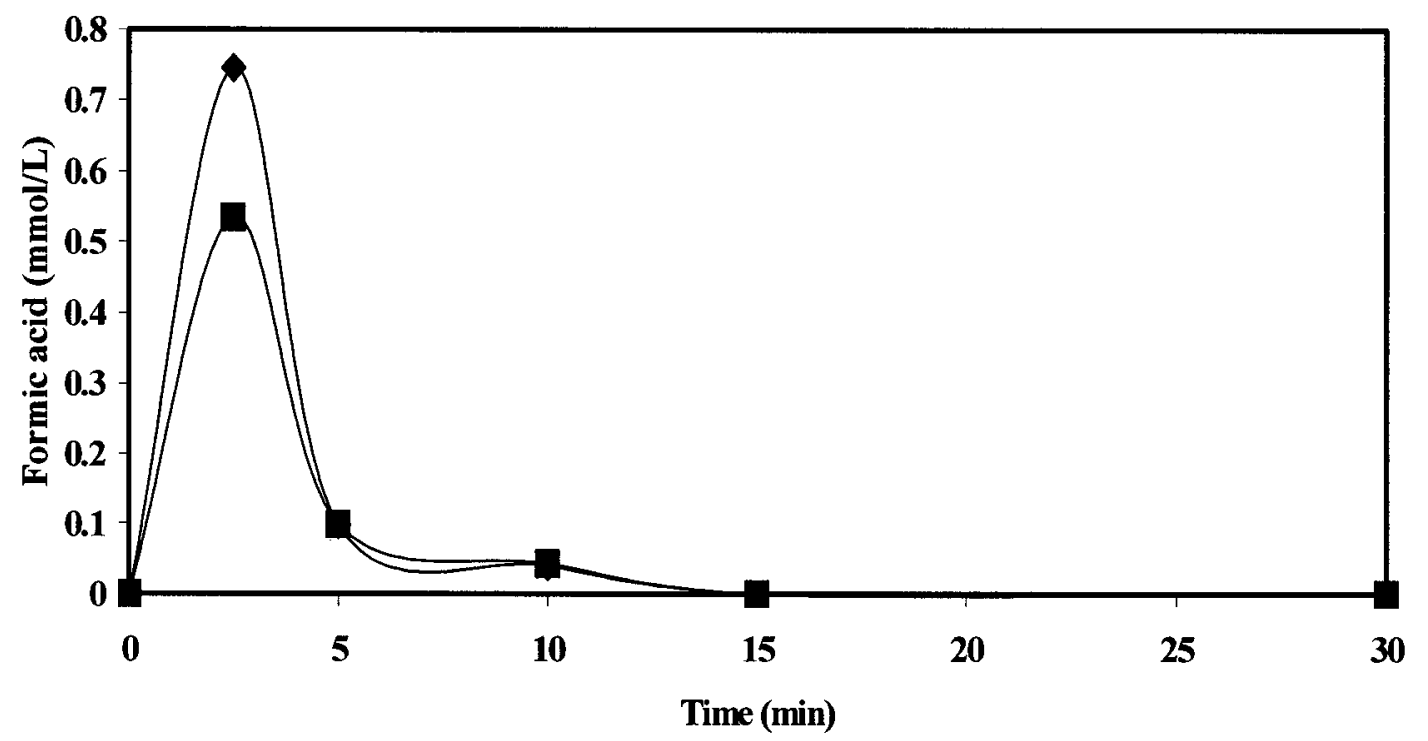

Figure 5.39: Formic acid profile for replicates, $\mathrm{T}=260^{\circ} \mathrm{C}, \mathrm{P}_{\mathrm{O} 2}, 1.72 \mathrm{MPa}, \mathrm{pH}=4$. 
In summary, the results show that the main intermediates were found to be acetic acid and formic acid. Negligible amounts of both propanoic acid and glycolic acid were also detected. In addition, a negligible amount of benzoquinone was identified by the Gas Chromatography Mass Spectrometry (GCMS). Most of the intermediates were degraded to $\mathrm{CO}_{2}$ and $\mathrm{H}_{2} \mathrm{O}$ as the reaction proceeded. However, only some of the acetic acid produced during the oxidation was degraded and the remaining stayed as a final product. 


\section{CHAPTER SIX}

\section{RESULTS AND DISCUSSIONS}

\section{WET AIR OXIDATION OF BENZENE ENHANCED BY PHENOL}

The co-oxidation method is used to enhance the wet air oxidation of many compounds (see Section 2.5). In this study, phenol was used to enhance the benzene degradation. Simultaneous benzene and phenol oxidation has been studied at a temperature range of $160-220^{\circ} \mathrm{C}$. In most experiments the initial phenol concentration ranged from 0.11 to $2.13 \mathrm{mmol} / \mathrm{L}$ while the concentration of benzene was kept constant at $5.63 \mathrm{mmol} / \mathrm{L} .100 \%$ excess of oxygen was used. However, at the beginning of this study, different conditions were applied, as described below.

\subsection{Wet Air Oxidation of Phenol in Absence of Benzene}

The wet air oxidation of phenol in the absence of benzene showed that $99.5 \%$ degradation can be achieved in 2.5 minutes at $220^{\circ} \mathrm{C}$ and oxygen pressure of $2.07 \mathrm{MPa}$. The initial phenol concentration was $5.31 \mathrm{mmol} / \mathrm{L}$ and the initial $\mathrm{pH}$ was set to be 4 . This experiment was repeated at $\mathrm{pH} 6$ with $1.38 \mathrm{MPa}$ of oxygen pressure and again more than $99 \%$ degradation was achieved within 2.5 minutes. In contrast to benzene, this shows that the $\mathrm{pH}$ in the range of 4 to 6 does not have a significant influence on the phenol degradation. An experiment using $2.13 \mathrm{mmol} / \mathrm{L}$ as the initial concentration of phenol has been conducted at $\mathrm{pH} 6$ with $100 \%$ excess of oxygen, which is the same as the excess that was used throughout this part of study. In this experiment, 95\% degradation was achieved within 2.5 minutes and after 5 minutes no phenol was detected. Those experiments 
showed that the degradation of phenol was very fast under the experimental conditions.

The above results are summarized in Table 6.1.

Table 6.1: Degradation of Phenol at $220^{\circ} \mathrm{C}$.

\begin{tabular}{|c|c|c|c||}
\cline { 2 - 4 } \multicolumn{1}{c|}{} & \multicolumn{3}{c||}{${\mathrm{C} / \mathrm{C}_{0} \text { of Phenol }}^{1}$} \\
\hline $\begin{array}{c}\text { Time } \\
(\mathrm{min})\end{array}$ & $\begin{array}{c}\mathrm{P}_{\mathrm{O} 2}=2.07 \mathrm{MPa} \\
\mathrm{pH}=4\end{array}$ & $\begin{array}{c}\mathrm{P}_{\mathrm{O} 2}=1.38 \mathrm{MPa} \\
\mathrm{pH}=6\end{array}$ & $\begin{array}{c}100 \% \text { excess of } \mathrm{P}_{\mathrm{O} 2} \\
\mathrm{pH}=6\end{array}$ \\
\hline 0 & 1 & 1 & 1 \\
\hline 2.5 & 0.005 & 0.006 & 0.05 \\
\hline 5 & 0.002 & 0 & 0 \\
\hline 10 & 0 & 0 & 0 \\
\hline
\end{tabular}

Both acetic acid and formic acid were identified as intermediates during phenol degradation. While the formic acid was further degraded, the acetic acid stayed as a final product, as seen on Figures 6.1-6.3. Also, it can be noted that at higher oxygen pressure and lower initial $\mathrm{pH}$ the degradation of formic acid was faster and slightly less amount of acetic acid was produced.

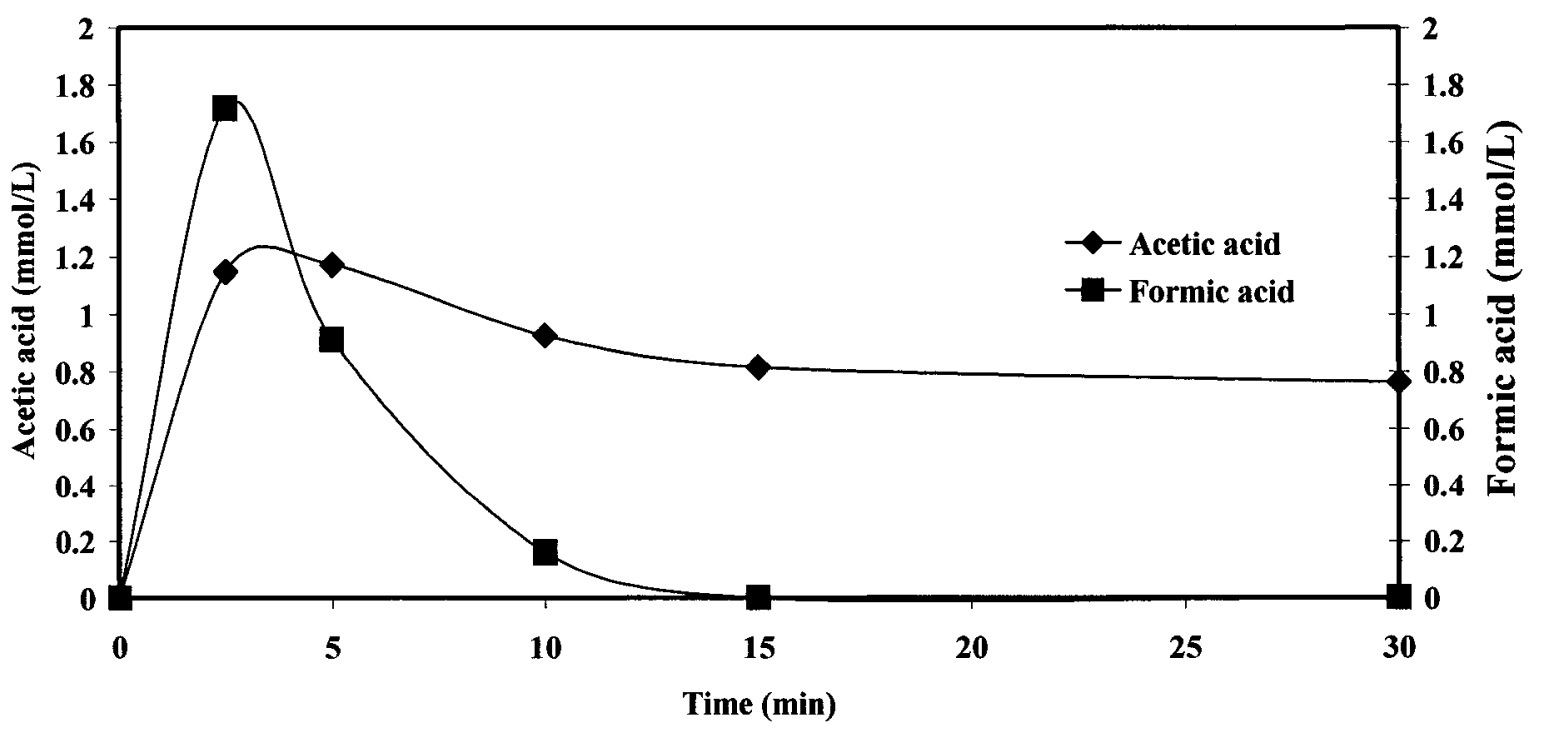

Figure 6.1: Acetic Acid and Formic Acid Profile, $\mathrm{T}=220^{\circ} \mathrm{C}, \mathrm{P}_{\mathrm{O} 2}=2.07 \mathrm{MPa}, \mathrm{pH}=4$. Initial Phenol Concentration $=5.31 \mathrm{mmol} / \mathrm{L}$. 


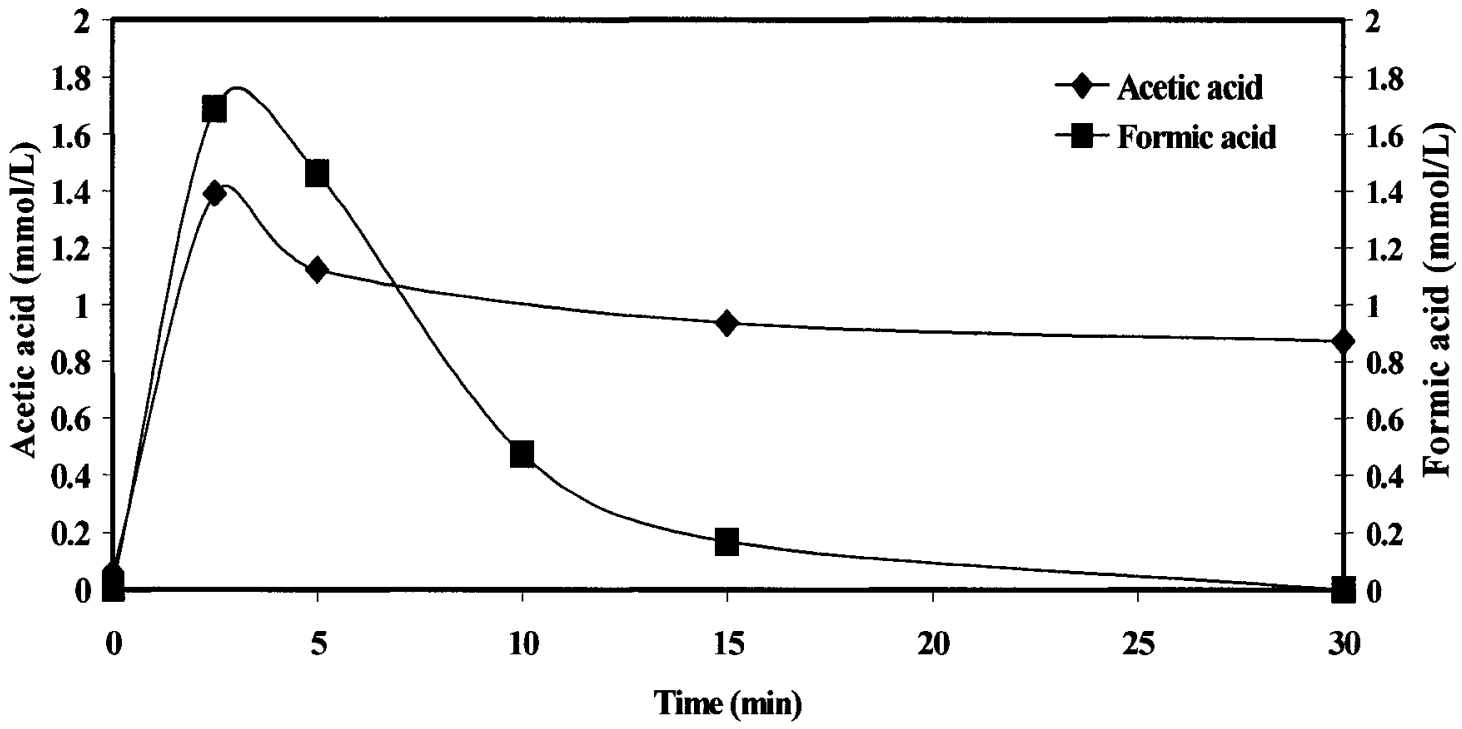

Figure 6.2: Acetic Acid and Formic Acid Profile, $\mathrm{T}=220^{\circ} \mathrm{C}, \mathrm{P}_{\mathrm{O} 2}=1.38 \mathrm{MPa}, \mathrm{pH}=6$. Initial Phenol Concentration $=5.31 \mathrm{mmol} / \mathrm{L}$.

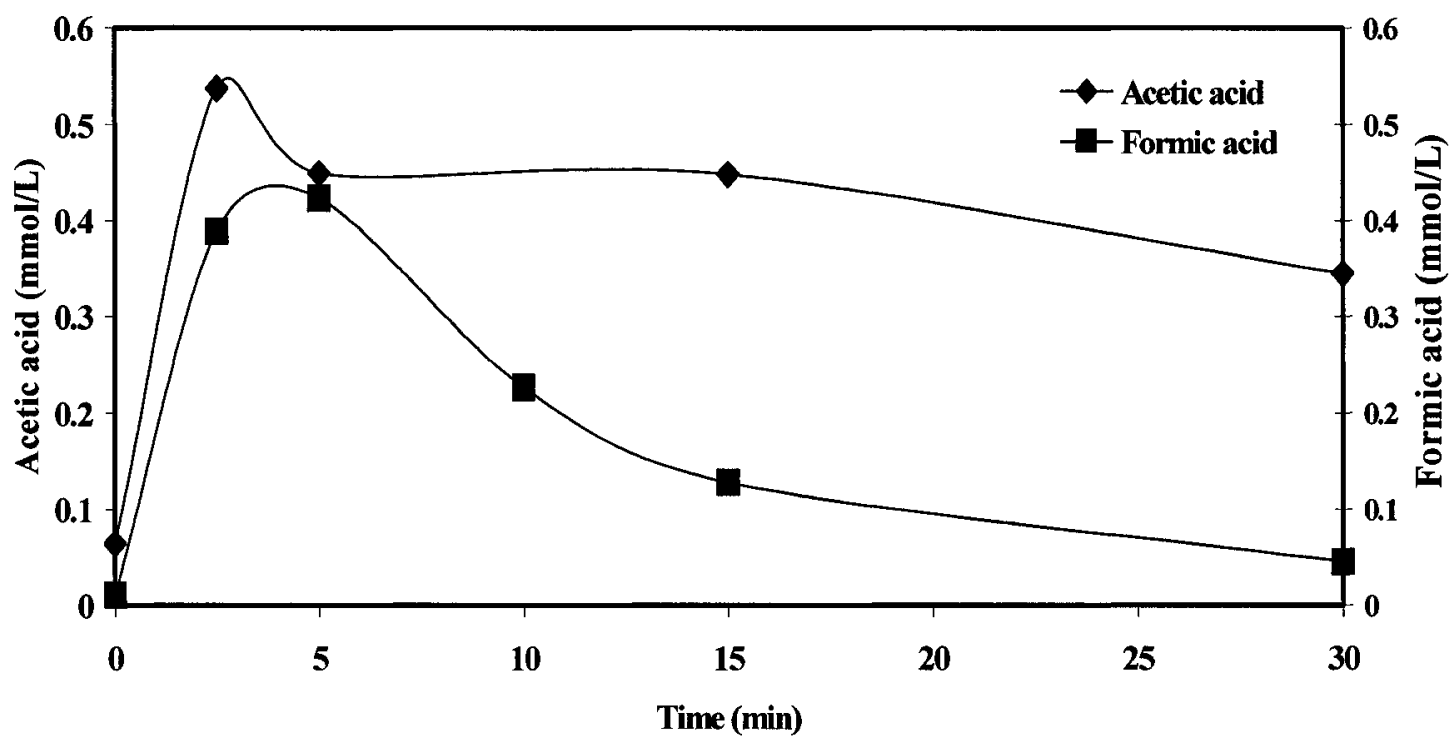

Figure 6.3: Acetic Acid and Formic Acid Profile, $\mathrm{T}=220^{\circ} \mathrm{C}, \mathrm{P}_{\mathrm{O} 2}=0.51 \mathrm{MPa}, \mathrm{pH}=4$. Initial Phenol Concentration $=2.13 \mathrm{mmol} / \mathrm{L}$. 


\subsection{Wet Air Oxidation of Benzene in Presence of Phenol}

Two experiments were done at $220^{\circ} \mathrm{C}$ and oxygen pressure of $1.72 \mathrm{MPa}$ at both initial pH 4 and pH 6 in order to study the effect of phenol on the degradation of benzene. The initial phenol concentration was $5.31 \mathrm{mmol} / \mathrm{L}$ while the initial benzene concentration was chosen to be the same as the initial concentration that was used in chapter 4 , i.e. $5.63 \mathrm{mmol} / \mathrm{L}$. It can be seen from Figure 6.4, that the fast oxidation of benzene was achieved in the presence of phenol and the results were almost identical for both $\mathrm{pH} 4$ and $\mathrm{pH} 6$, which means that in the presence of phenol the effect of initial $\mathrm{pH}$ was not significant. Figure 6.5 shows an extremely fast degradation of phenol and it also suggests that the initial $\mathrm{pH}$ of the reaction did not have any effect on the phenol degradation.

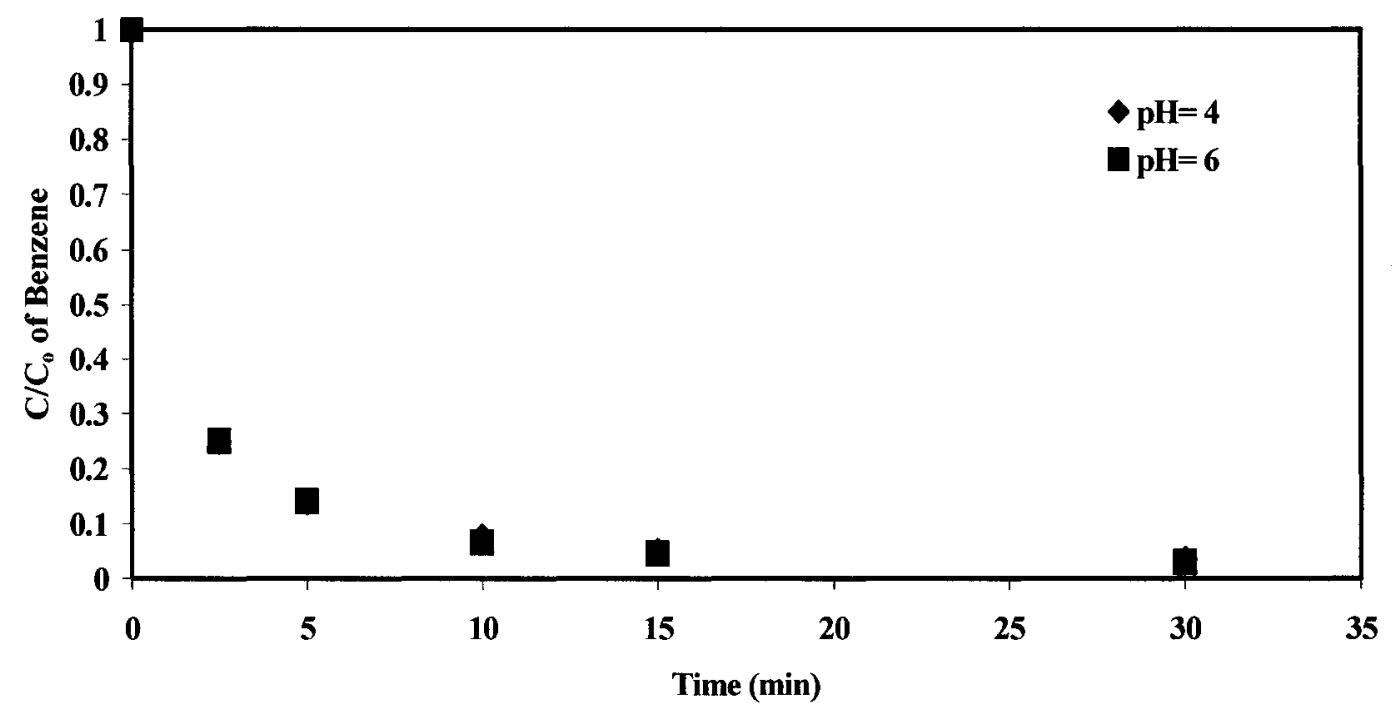

Figure 6.4: Degradation of Benzene at $220^{\circ} \mathrm{C}, \mathrm{P}_{\mathrm{O} 2}=1.72 \mathrm{MPa}$. 


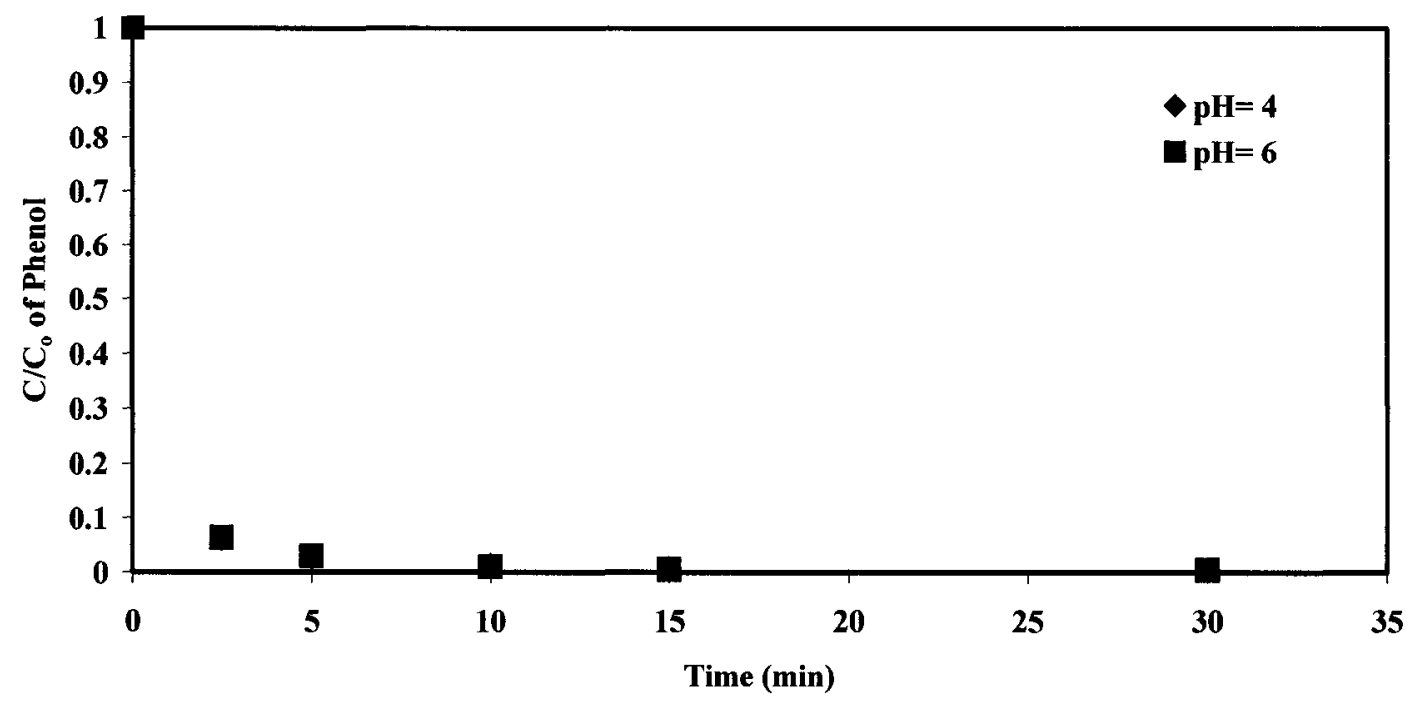

Figure 6.5: Degradation of Phenol at $220^{\circ} \mathrm{C}, \mathrm{P}_{\mathrm{O} 2}=1.72 \mathrm{MPa}$.

\subsubsection{Effect of the Initial Phenol Concentration on Benzene Degradation}

Several experiments have been carried out with initial concentrations of phenol ranging from 0.11 to $2.13 \mathrm{mmol} / \mathrm{L}$, in order to determine the effect of the initial phenol concentration on the wet air oxidation of benzene. The benzene concentration was kept constant at $5.63 \mathrm{mmol} / \mathrm{L}$. These experiments were done at $220^{\circ} \mathrm{C}$ and $100 \%$ excess of $\mathrm{O}_{2}$. The initial $\mathrm{pH}$ of the solution was 6 . From the Figure 6.6, it is apparent that the increased concentration of phenol enhanced the degradation of benzene dramatically, especially during the first 5 minutes. While no benzene degradation was achieved in 15 minutes in the absence of phenol, more than $95 \%$ degradation of benzene was achieved even with the smallest amount of phenol used in the experiment $(0.11 \mathrm{mmol} / \mathrm{L})$. After 15 minutes, the degradation rates were comparable. However, when the initial phenol concentration was increased from 1.59 to $2.13 \mathrm{mmol} / \mathrm{L}$, no change in the degradation rate was detected. 
As was mentioned earlier in Chapter 2, the effect of phenol can be attributed to the formation of free radicals and the active intermediates.

The effect of the initial phenol concentration at $200^{\circ} \mathrm{C}$ with $100 \%$ excess $\mathrm{O}_{2}$ can be seen in Figure 6.7. The results show that at lower temperature the initial phenol concentration has more effect on the benzene degradation than at $220^{\circ} \mathrm{C}$. While $89 \%$ benzene was degraded in 10 minutes with initial phenol concentration of $0.53 \mathrm{mmol} / \mathrm{L}$, only $27 \%$ degradation was achieved when the initial phenol concentration was lowered to $0.27 \mathrm{mmol} / \mathrm{L}$. However, after 30 minutes the results were comparable. The above results show that the presence of phenol, even at low concentration, enhanced the degradation of benzene dramatically. As was shown in Section 4.4, at this temperature the degradation of benzene was not reproducible, but in the presence of phenol, this was not observed. It appears that phenol acts as a catalyst by lowering the activation energy.

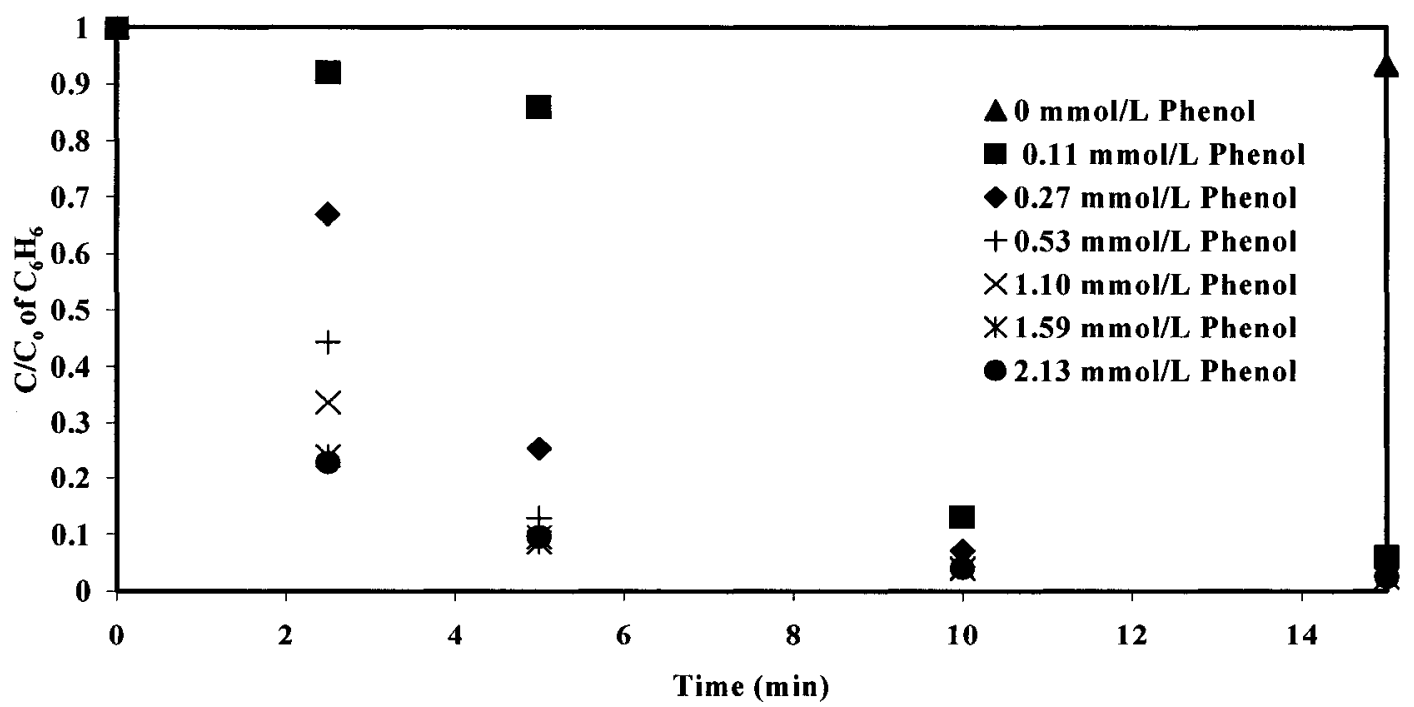

Figure 6.6: Degradation of Benzene at Different Initial Phenol Concentrations, $\mathrm{T}=220^{\circ} \mathrm{C}$, $100 \%$ Excess $\mathrm{O}_{2}$, Initial $\mathrm{pH}=6$. 


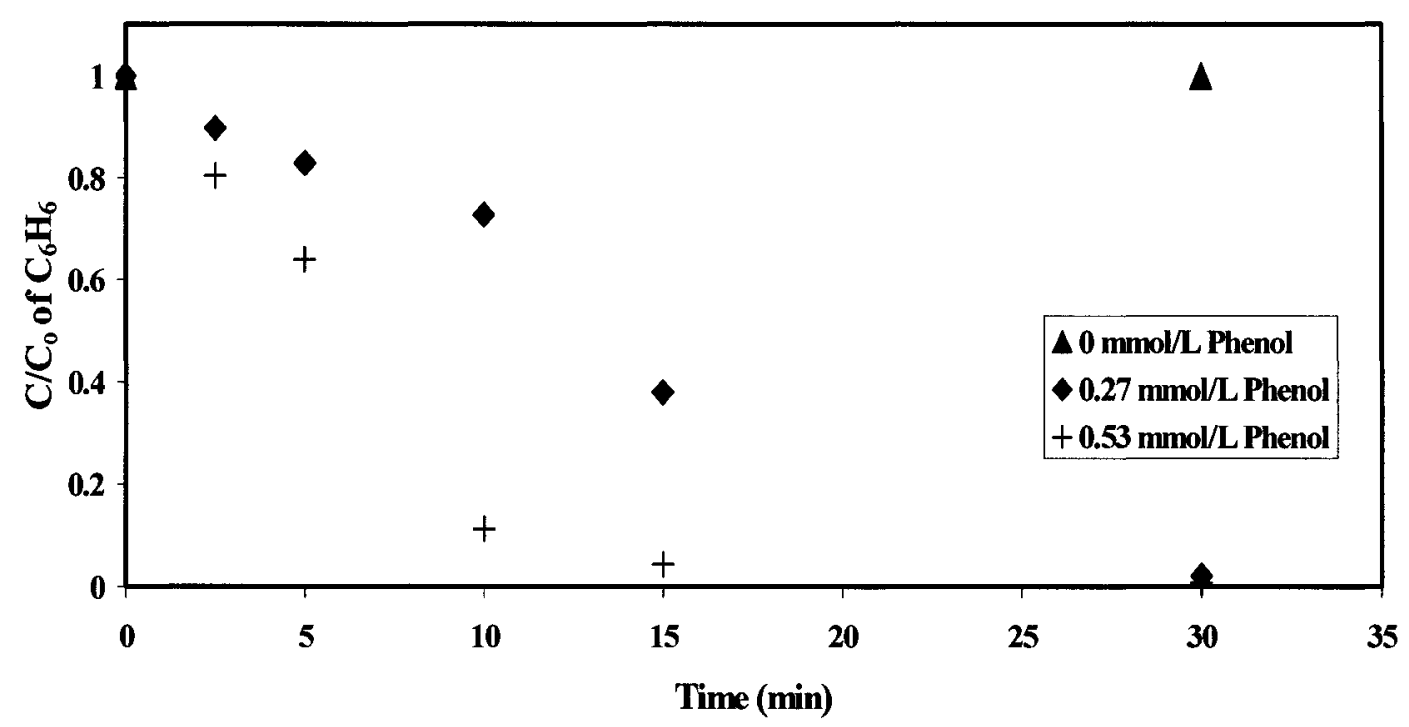

Figure 6.7: Degradation of Benzene at Different Initial Phenol Concentrations, $\mathrm{T}=200^{\circ} \mathrm{C}$, $100 \%$ Excess $\mathrm{O}_{2}$, Initial $\mathrm{pH}=6$.

\subsubsection{Effect of Temperature on Benzene Degradation in the Presence of Phenol}

In the previous section, the effect of the initial phenol concentration on benzene degradation was studied at constant temperature. However, in this section the initial phenol concentration was kept constant and the temperature was varied to study the effect of the temperature on the benzene degradation at constant initial phenol concentration. Two different initial phenol concentrations were used. The initial selected phenol concentration was the lowest phenol concentration that gave good results at the lowest temperature used, i.e. $0.27 \mathrm{mmol} / \mathrm{L}$, when the lowest temperature was $200^{\circ} \mathrm{C}$ and 0.53 $\mathrm{mmol} / \mathrm{L}$ when the lowest temperature was $160^{\circ} \mathrm{C}$. The oxygen concentration was kept at $100 \%$ excess and the initial $\mathrm{pH}$ was 6 . Figure 6.8 shows the degradation of benzene at both 200 and $220^{\circ} \mathrm{C}$. The initial phenol concentration was $0.27 \mathrm{mmol} / \mathrm{L}$. It can be seen that when the temperature was increased from 200 to $220^{\circ} \mathrm{C}$ a considerably faster 
degradation was achieved. The co-oxidation of benzene was further studied with the initial phenol concentration of $0.53 \mathrm{mmol} / \mathrm{L}$ at 4 different temperatures ranging from 160 to $220^{\circ} \mathrm{C}$ (Figure 6.9). The results show that the benzene degradation was rather slow at $160^{\circ} \mathrm{C}$ and only around $50 \%$ degradation was achieved within 60 minutes. However, with the increasing temperature, the degradation rate of benzene became faster and more degradation was achieved during the first 20 minutes. This implies that the higher the temperature, the faster phenol oxidation was achieved and this resulted in the rapid formation of the free radicals and the active intermediates. Also, as mentioned before higher temperatures lead to higher oxygen solubility in the liquid phase.

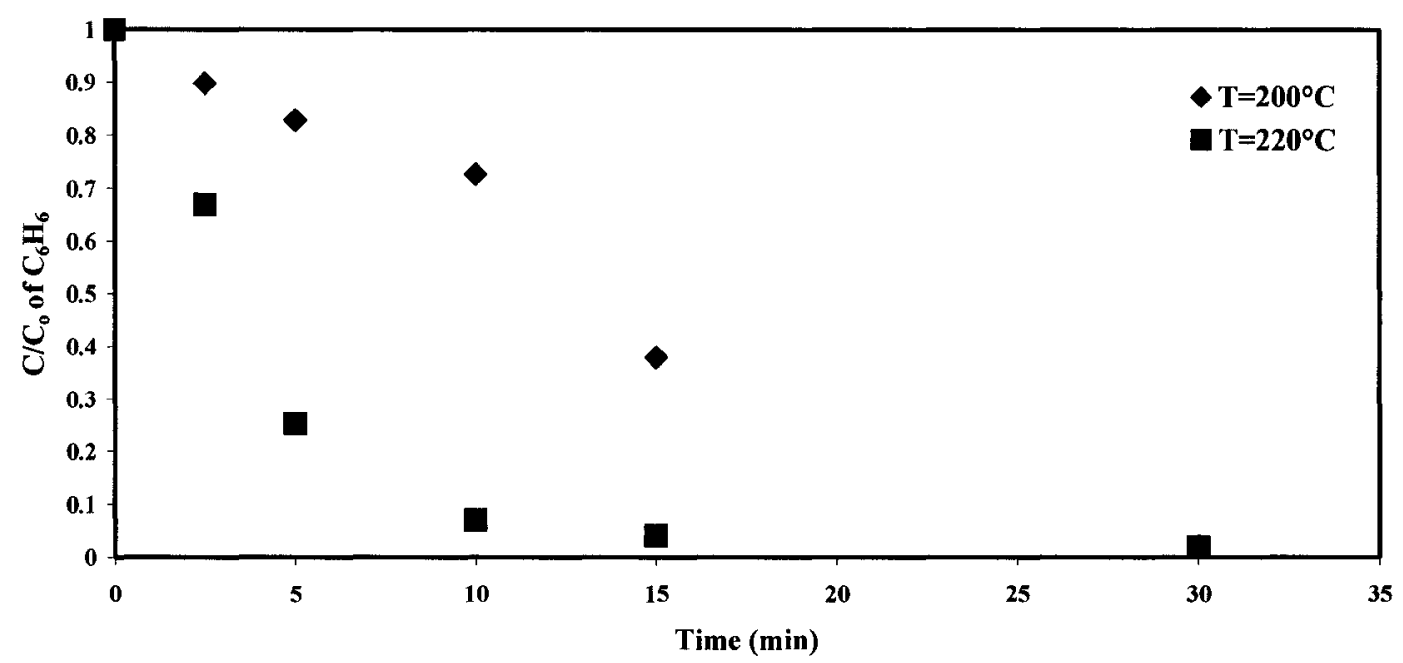

Figure 6.8: Degradation of Benzene at Different Temperatures, 100\% Excess $\mathrm{O}_{2}$, Initial Phenol Concentration $=0.27 \mathrm{mmol} / \mathrm{L}$, Initial $\mathrm{pH}=6$. 


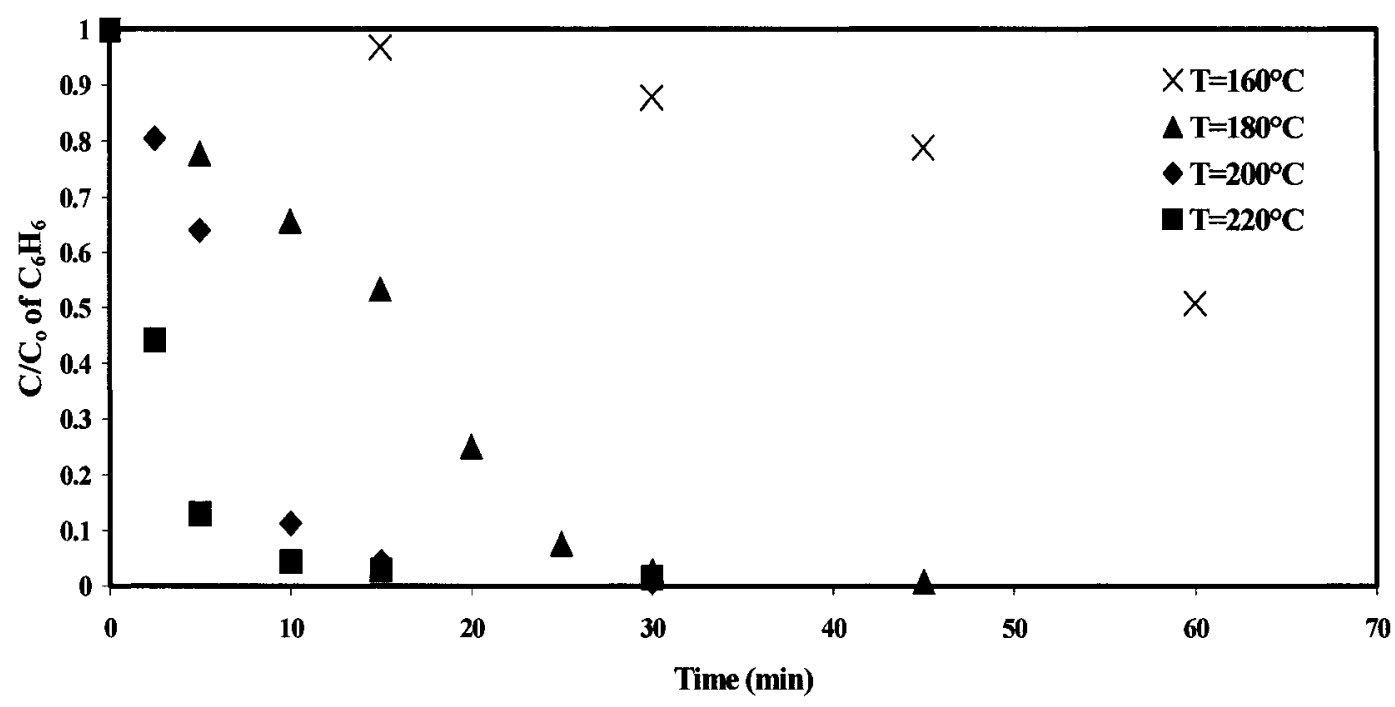

Figure 6.9: Degradation of Benzene at Different Temperatures, $100 \%$ Excess $\mathrm{O}_{2}$, Initial Phenol Concentration $=0.53 \mathrm{mmol} / \mathrm{L}$, Initial $\mathrm{pH}=6$.

\subsubsection{Effect of Benzene on the Phenol Oxidation}

Figure 6.10 shows the phenol profile at different temperatures when $0.53 \mathrm{mmol} / \mathrm{L}$ of phenol was used as initial concentration. It is apparent from the Figure that at $220^{\circ} \mathrm{C}$ the degradation of phenol was very fast. However, at $200^{\circ} \mathrm{C}$ the concentration of phenol decreased during the first 5 minutes of the oxidation, followed by the slight increase, and by final degradation of phenol. The same oxidation path can also be seen at $180^{\circ} \mathrm{C}$. This suggests that, at the beginning of the oxidation, the small amount of phenol was degraded, and it was followed by the partial conversion of benzene to phenol which was then degraded. However, the peaks were shifted to the right as the oxidation temperatures decreased. At $160^{\circ} \mathrm{C}$, the concentration of phenol increased with time, which implies that the rate of oxidation of benzene to phenol was faster than the rate of degradation of phenol during the duration of the experiment. 
Figure 6.11 shows the effect of benzene on the phenol profile when the initial phenol concentration was $0.27 \mathrm{mmol} / \mathrm{L}$. It can be seen that in first 2.5 minutes at $220^{\circ} \mathrm{C}$ the degradation of benzene was faster than the degradation of phenol which resulted in accumulation of phenol after which the phenol started to degrade. At $200^{\circ} \mathrm{C}$, the degradation of phenol was faster than that of benzene in the first 5 minutes, and after that the oxidation of benzene became faster hence the concentration of phenol started to increase and it reached a peak after 15 minutes. After that the concentration of phenol started to decrease. After 30 minutes of oxidation almost the same degree of phenol oxidation has been obtained. These results show that both the rate of production and the rate of degradation of phenol are highly affected by the temperature. While the rate of the production of phenol was higher than the rate of degradation at lower temperatures, i.e. at $160^{\circ} \mathrm{C}$, the opposite could be seen at higher temperatures i.e. at $220^{\circ} \mathrm{C}$. These results also showed that the first stage in the wet air oxidation of benzene was the oxidation of benzene to phenol.

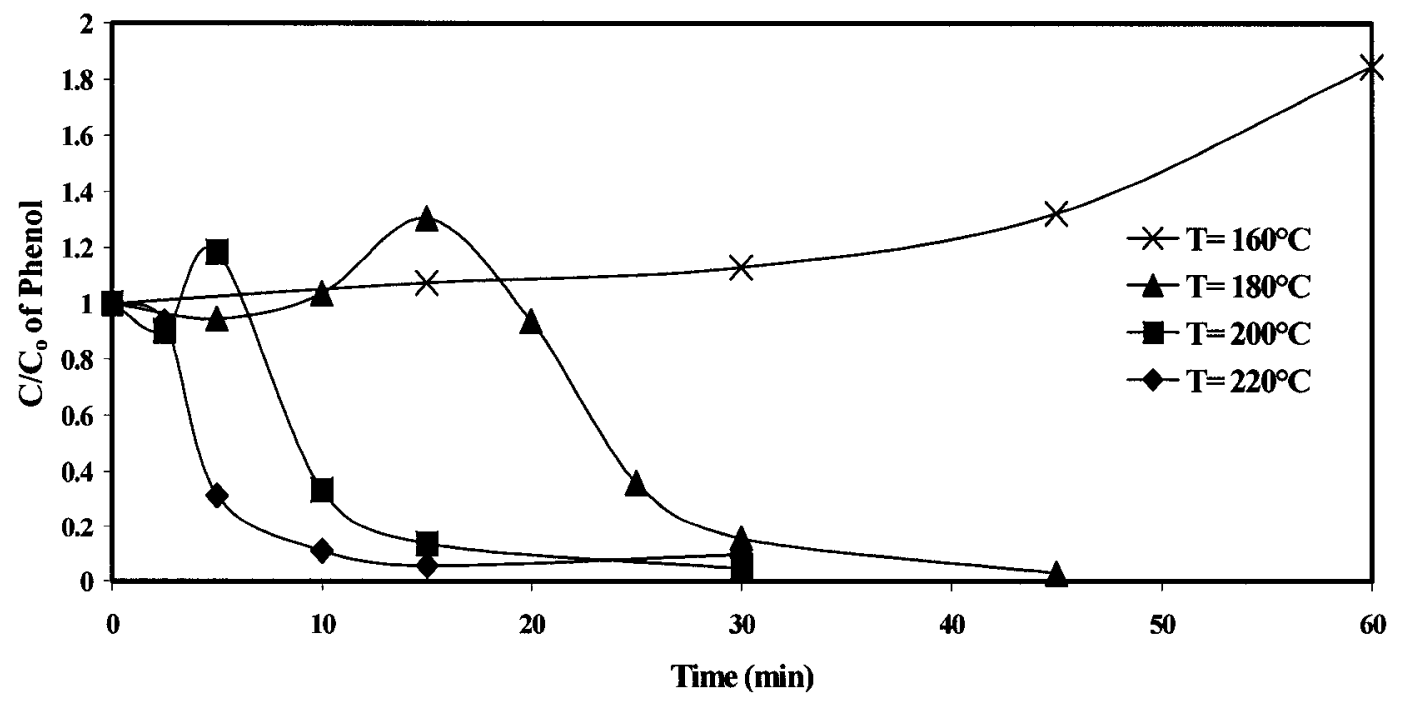

Figure 6.10: Normalized concentration of Phenol with Time, 100\% Excess $\mathrm{O}_{2}$, Initial $\mathrm{pH}=6$, Initial Phenol Concentration $=0.53 \mathrm{mmol} / \mathrm{L}$. 


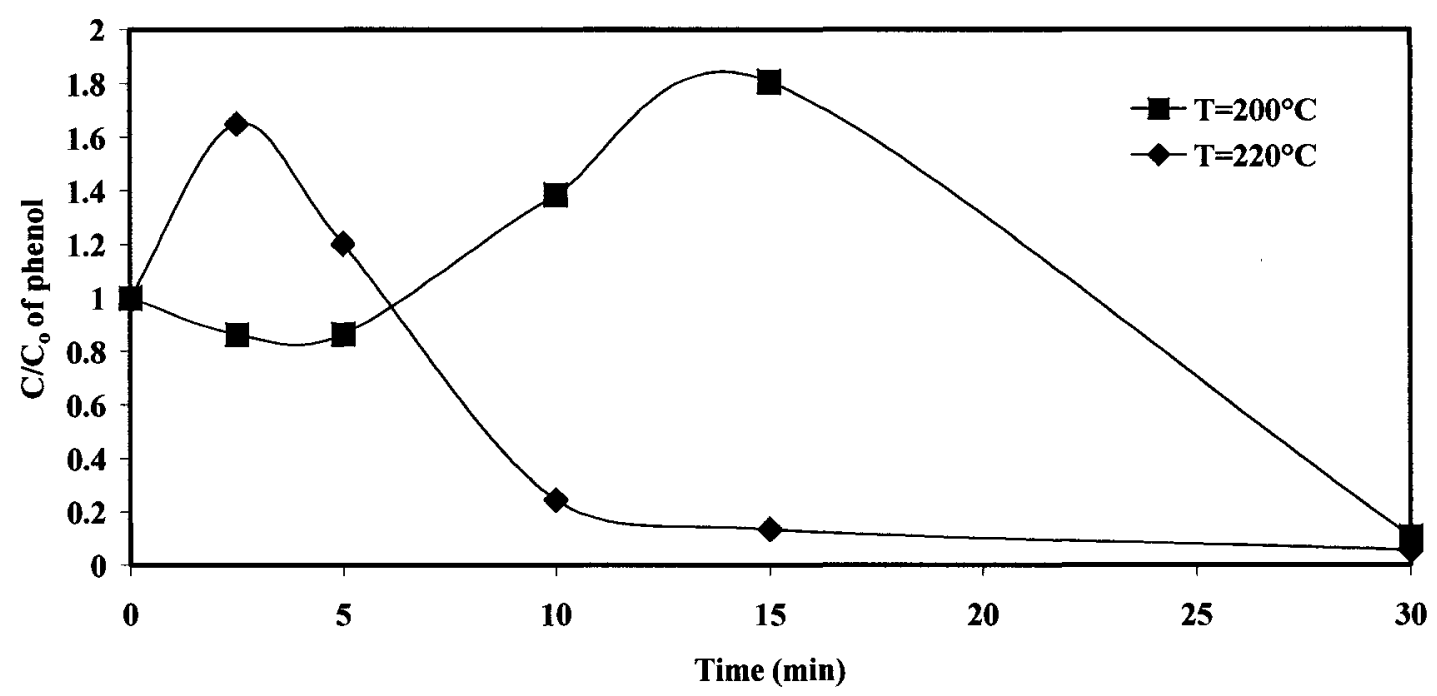

Figure 6.11: Normalized concentration of Phenol with Time, $100 \%$ Excess $\mathrm{O}_{2}$, Initial $\mathrm{pH}=6$, Initial Phenol Concentration $=0.27 \mathrm{mmol} / \mathrm{L}$.

\subsection{Reaction Kinetics of Benzene Oxidation}

The use of two first order reaction kinetics model represented well the WAO on many phenolic compounds [33, 39]. Lin et al. [41] also showed that this model worked in their study on the WAO of high concentration wastewater. It can be seen from figure 6.12 that this model fit our reaction well and it consists of 2 steps; namely the fast reaction step and the slow reaction step. While at $220^{\circ} \mathrm{C}$ only the fast step can be detected, at $160^{\circ} \mathrm{C}$ only the slow step exists. Figure 6.13 shows that the reaction follows the Arrhenius correlation and the activation energy was calculated to be $21.1 \mathrm{~kJ} / \mathrm{mol}$ and $1.2^{*} 10^{2} \mathrm{~kJ} / \mathrm{mol}$ for the fast and slow step, respectively. 


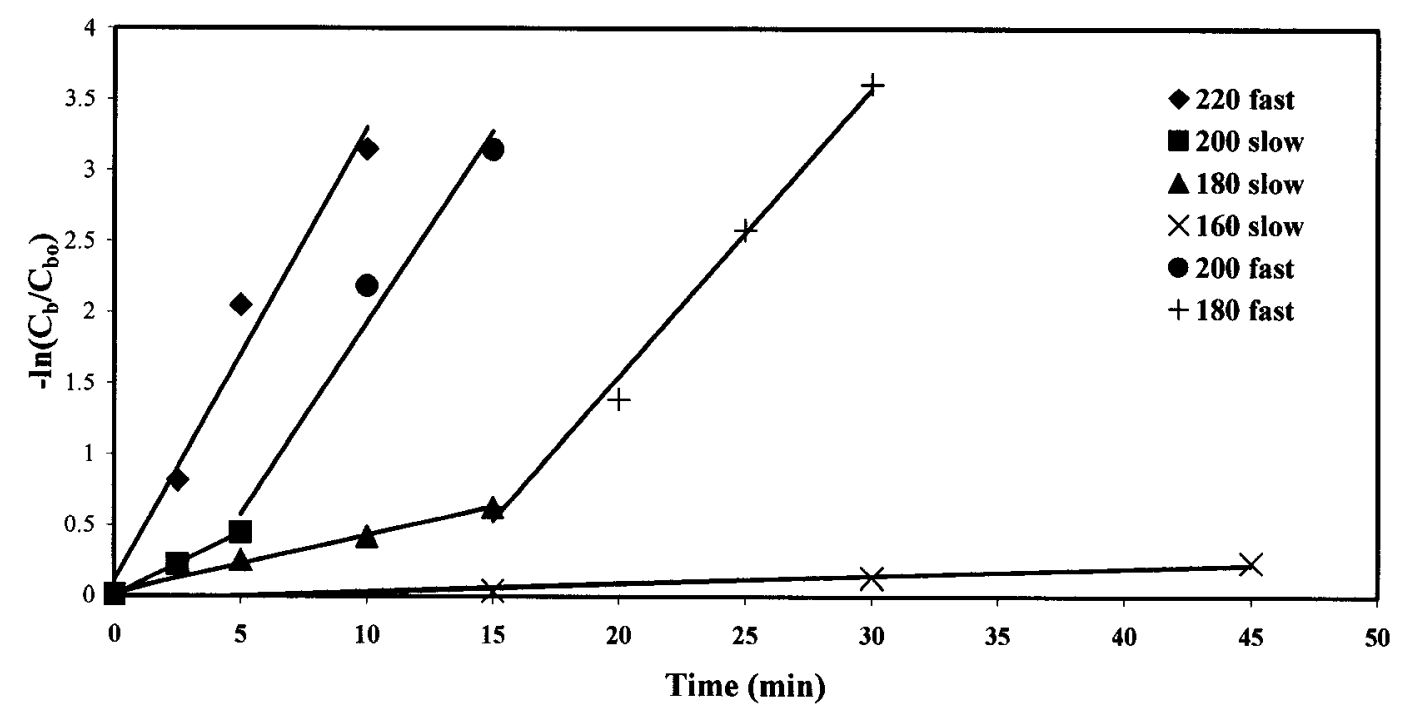

Figure 6.12: Pseudo First Order Kinetic Plot for Benzene.

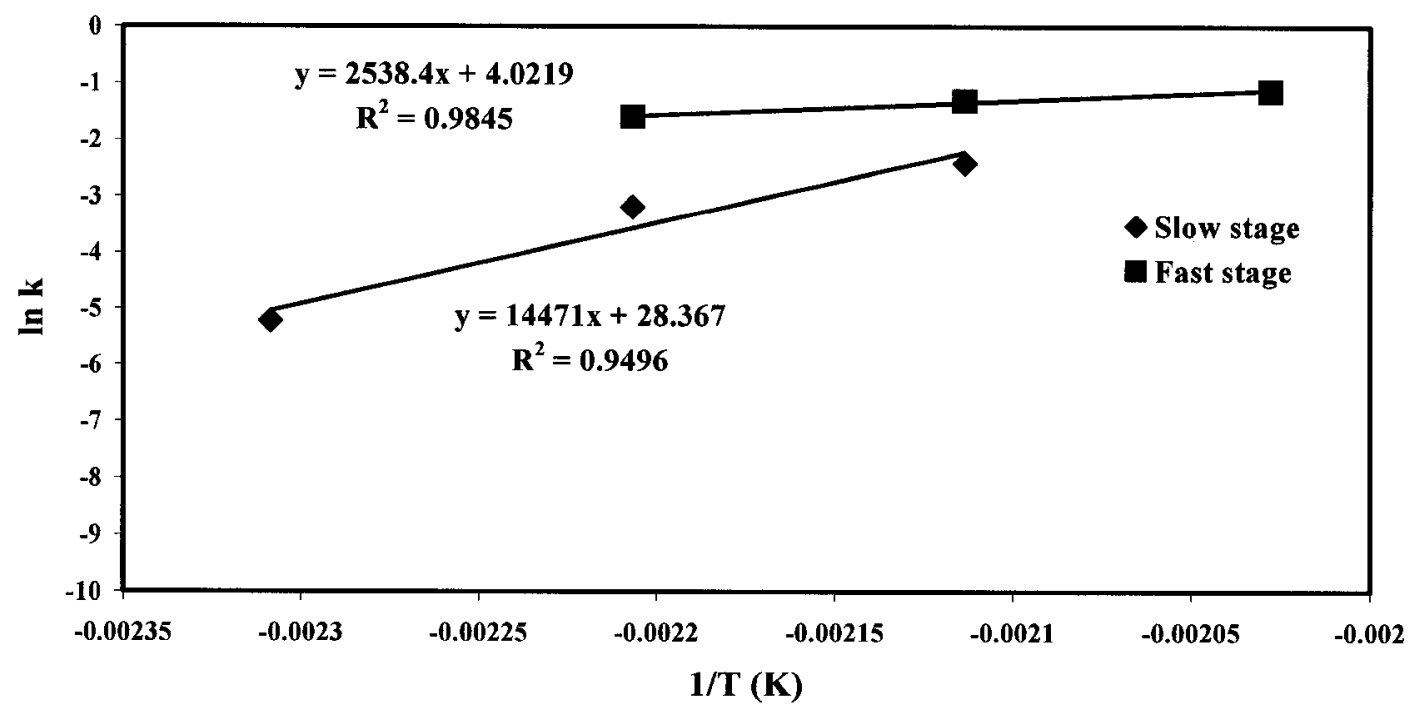

Figure 6.13: Arrhenius Plot for Pseudo First Order Rate Constant Calculated from Benzene Removal Data. 


\subsection{Repeatability of the Experiments}

The repeatability of both benzene and phenol has been tested. Figure 6.14 shows the repeatability of benzene data at $220^{\circ} \mathrm{C}$ and $100 \%$ excess of oxygen pressure with an initial $\mathrm{pH}$ of 6 . The initial phenol concentration was $0.27 \mathrm{mmol} / \mathrm{L}$. It is apparent that the excellent repeatability was achieved. A good repeatability was also achieved for phenol as appears in Figure 6.15.

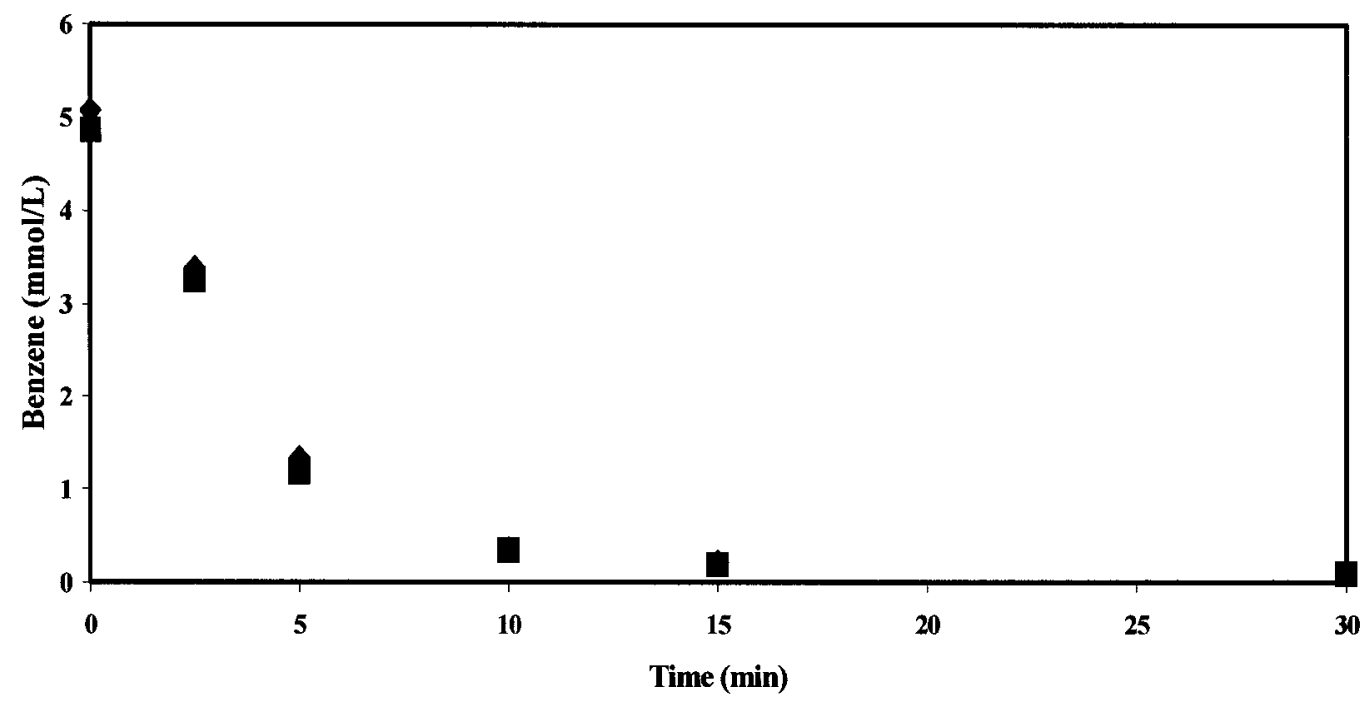

Figure 6.14: Repeatability of Benzene Result at $220^{\circ} \mathrm{C}, 100 \%$ Excess $\mathrm{O}_{2}$, Initial $\mathrm{pH}=6$, Initial Phenol Concentration $=0.27 \mathrm{mmol} / \mathrm{L}$. 


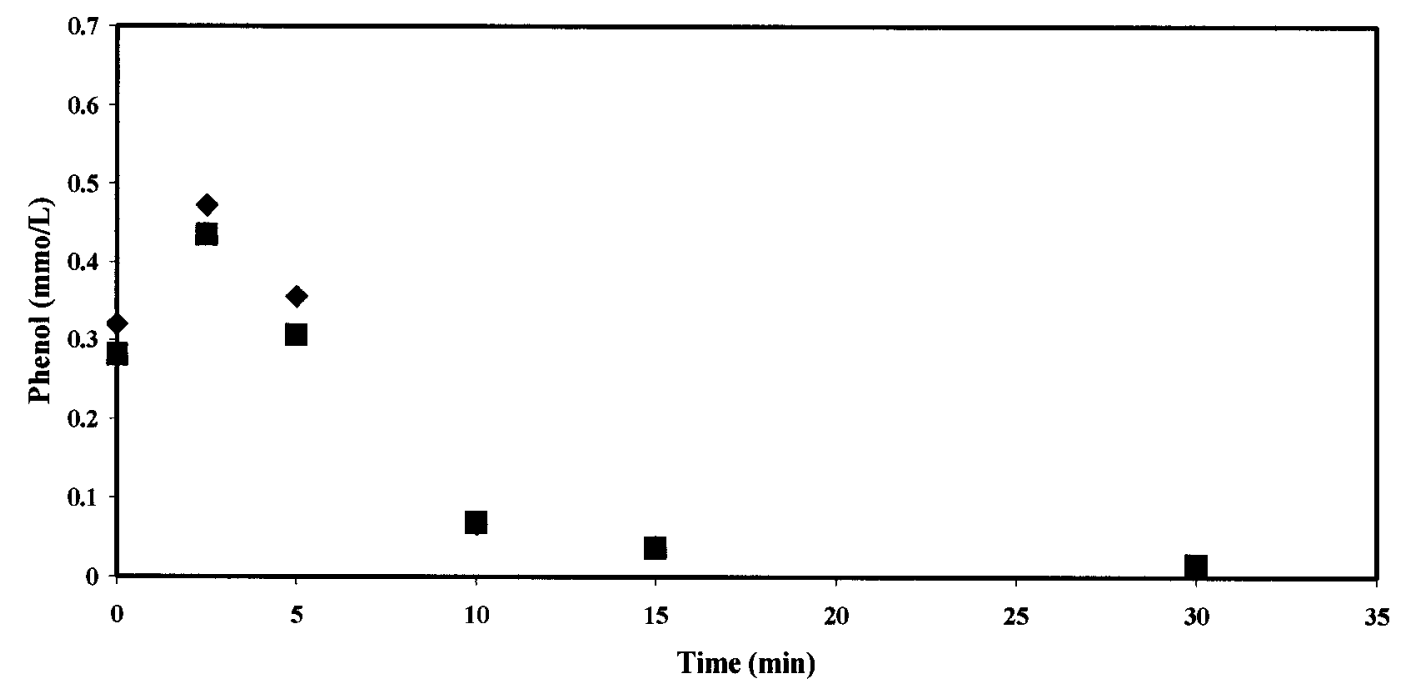

Figure 6.15: Repeatability of Phenol Result at $220^{\circ} \mathrm{C}, 100 \%$ Excess $\mathrm{O}_{2}$, Initial $\mathrm{pH}=6$, Initial Phenol Concentration $=0.27 \mathrm{mmol} / \mathrm{L}$.

\subsection{Proposed Simplified Pathway for Oxidation of Benzene}

From the results obtained in this chapter it was obvious that the benzene first oxidized to phenol and after that phenol further degraded. Also, as mentioned earlier, the benzoquinone has been identified by the GCMS. This means that the phenol was first degraded to either hydroquinone or catechol, or both of them, which was further degraded to the benzoquinone. The benzoquinone will further oxidized through many intermediates that have not been identified in this study. Later, those intermediates were degraded to low molecular weight organic acids. Some of these acids were identified in this study. Accordingly, the following pathway was proposed: 


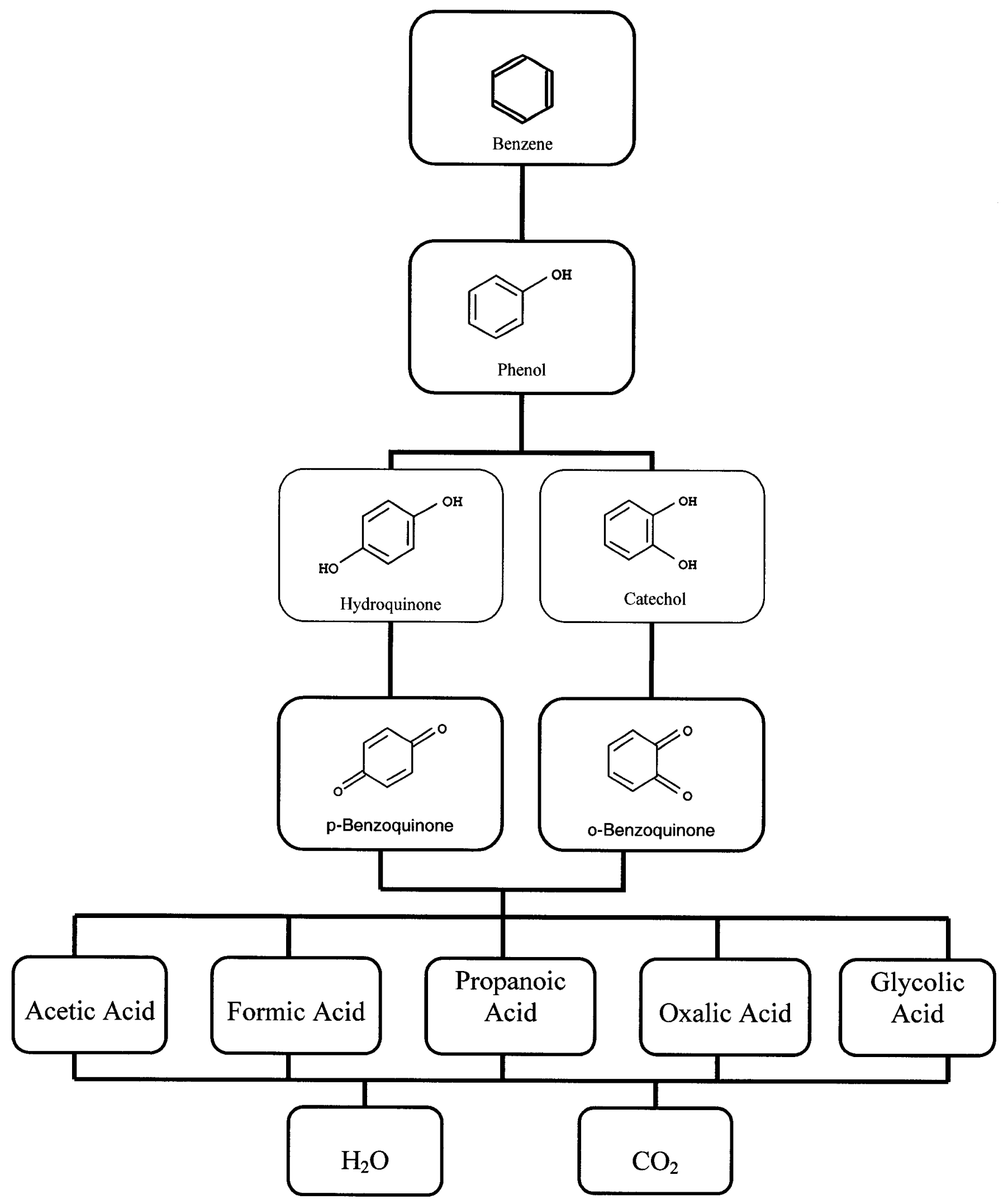

Figure 6.16: Simplified Pathway for Oxidation of Benzene. 


\section{CHAPTER SEVEN \\ CONCLUSIONS AND RECOMMENDATIONS}

\subsection{Conclusions}

The following can be concluded from the work:

- The rate of benzene degradation depends on temperature, pressure, $\mathrm{pH}$ and the compositions of the reaction medium.

- At fixed temperature, the lower the $\mathrm{pH}$ the higher the rate of benzene degradation because of the accumulation of the free radicals at the lower $\mathrm{pH}$. However, the major effect of $\mathrm{pH}$ was at lower oxidation temperatures.

- The $\mathrm{pH}$ of the solution kept changing throughout the reaction because of the production and degradation of the intermediates.

- Faster benzene degradation has been obtained with the increasing partial pressure of oxygen, especially at the first 5 minutes of the reaction time. The main reason is that the higher oxygen pressure resulted in the higher amount of oxygen dissolved in the liquid phase.

- The results showed that the reaction can be represented by two first order reaction with respect to benzene concentration and oxygen partial pressure. The reaction occurs in two steps, a fast step followed by a slow step. Most of the benzene was degraded during the fast step. When the initial $\mathrm{pH}$ was 4 , the activation energy for the fast step was found to be $10.3 \mathrm{~kJ} / \mathrm{mol}$. 
- Considerable TOC reduction was achieved and the degree of TOC reduction increased with temperature. This implies that the reaction tends to go to completion.

- Lower amounts of intermediates were produced at higher oxidation temperatures because at higher temperatures all reactions tend to go to completion.

- The main intermediates were found to be acetic acid and formic acid. Negligible amounts of both propanoic acid and glycolic acid were also detected. In addition, a negligible amount of benzoquinone was identified. Acetic acid was the most stable product.

- The optimum conditions for benzene degradation were found to be $220^{\circ} \mathrm{C}$ and oxygen partial pressure of $1.38 \mathrm{MPa}$ in the $\mathrm{pH}$ range of 4-5. However at these conditions higher amounts of acids was produced.

- Addition of phenol to the system enhanced the benzene degradation because the free radicals that were produced during the phenol oxidation were used to initiate the oxidation of benzene.

- Since phenol is a common component that can be found in many of the wastewater streams and since it can enhance the degradation of benzene and some other component, this can have a significant economic impact.

- The higher the concentration of phenol, the higher the benzene degradation at a given temperature. However, the addition of $1.59 \mathrm{mmol} / \mathrm{L}$ of phenol was found to 
be the optimum concentration. Above $1.59 \mathrm{mmol} / \mathrm{L}$, the benzene degradation was not increased.

- The degradation of benzene enhanced with phenol proceeds in two stages and the activation energy was determined to be $21.1 \mathrm{~kJ} / \mathrm{mol}$ and $1.2 * 10^{2} \mathrm{~kJ} / \mathrm{mol}$ for the fast and slow step, respectively

- A simplified pathway for the reaction suggested that the benzene first oxidized to phenol, followed by further phenol degradation.

\subsection{Recommendations for future work}

- Due to the present experimental setup, there was a limitation in the number of the samples that could have been collected during the experiments. It is recommended to modify the experimental setup so that more samples could be collected in order to test the kinetic model.

- It is recommended to use the High Pressure Liquid Chromatography (HPLC) to analyze the samples especially those that can be collected periodically when the oxidation is fast in order to identify if there are another intermediates produced in addition to those identified in this study.

- Different catalysts should be tried at different conditions to find out if they could enhance the benzene degradation. 
- Since the metal wall can destroy the free radicals it is recommended to study the effect of Pyrex liner.

- It is recommended to try different additives, other than phenol, which might enhance the benzene degradation. An example of such an additive is hydroquinone, which is known to be a free radical initiator.

- Oxidizing agent other than oxygen such as ozone and hydrogen peroxide can be used for the reaction.

- Effect of impeller speed on the benzene degradation should be studied at different experimental conditions.

\subsection{Contributions to Knowledge}

As to our knowledge, this is the first study that deals with the wet air oxidation of benzene. The results that were obtained were very promising. The degradation of benzene was enhanced by lowering the initial $\mathrm{pH}$ of the reaction medium and enhanced further by the addition of phenol. From the results that were obtained, the optimum conditions were found, such as the optimum temperature, pressure, $\mathrm{pH}$ and the amount of the initial phenol. In addition, kinetic study was performed for the oxidation of benzene. Some of the oxidation intermediates were identified and a simplified pathway for benzene oxidation was proposed. 


\section{REFERENCES}

1. Anderson, R. T.; Lovley, D. R. Ecology and biogeochemistry of in situ groundwater bioremediation. Adv. Microb. Ecol., 1997, 15, 289.

2. Annual book of ASTM standard, Water environmental technology, 2006, 11.02, D1252, 38.

3. Baillod, C. R.; Faith, B. M.; Masi, O. Fate of specific pollutants during wet oxidation and ozonation. Environ. Progress 1982, l (3), 217.

4. Baillod, C. R.; Lamparter, R. A.; Barna, B. A. Wet oxidation for industrial waste treatment. Chem. Eng. Prog. 1985, 81 (3), 52.

5. Banerjee, S; Yalkowsky, S. H.; Valvani, S. C. Water solubility and octanol/water partition coefficients of organics. Limitations of the solubility-partition coefficient correlation. Environ Sci Technol, 1980, 14, 1227.

6. Bhargava, S.K., Tardio, J., Prasad, J., Foger, K., Akolekar, D.B., and Grocott, S.C., Wet Oxidation and Catalytic Wet Oxidation., Ind. Eng. Chem. Res. 2006, $45(4), 1221$.

7. Birchmeier, M.J., Hill, C.G., Houtman, C.J., Atalla, R.H., Weinstock, I.A., Enhanced wet air oxidation: synergistic rate acceleration upon effluent recirculation. Ind. Eng. Chem. Res.2000, 39, 55.

8. Chowdhury, A. K.; Copa, W. C. Wet air oxidation of toxic and hazardous organics in industrial wastewaters. Ind. Chem. Eng. 1986, 28 (3), 3. 
9. Christensen, T.; Kjeldsen, P.; Albrechtsen, H.; Heron, G.; Nielsen, P.; Bjerg, P; Holm, P. Attenuation of landfill leachate pollutant in aquifers. Crit. Rev. Environ. Sci. Technol., 1994, 24, 119.

10. Coates, J. D.; Chakraborty, R.; Lack, J. G.; O'Connor, S. M.; Cole, K. A.; Bender, K. S.; Achenbach, L. A., Anaerobic benzene oxidation coupled to nitrate reduction in pure culture by two strains of Dechloromonas, Nature, 2001, 411,1039.

11. Collyer, M.J.; Kubes, G. J.; Berk, D. Catalytic wet oxidation of thermomechanical pulping sludge. J. Pulp Pap. Sci. 1997, 23, J522.

12. Earhart, J. P.; Won, K. W.; Wong, H. Y.; Prausnitz, J. M.; King, C. J. Recovery of organic pollutants via solvent extraction. Chem. Eng. Progress 1977, 73 (5), 67.

13. Emanuel, N. M.; Zaikov, G. E.; Maitus, Z. K. Oxidation of Organic Compounds. Medium Effects in Radical Reactions; Pergamon Press: Oxford, U.K., 1984.

14. Fajerwerg, K.; Debellefontaine, H. Wet oxidation of phenol by hydrogen Peroxide using heterogeneous catalysis Fe-ZSM-5: a promising catalyst. Appl. Catal. B 1996, 10, L229.

15. Fajerwerg, K.; Foussard, J. N.; Perrard, A.; Debellefontaine, H. Wet oxidation of phenol by hydrogen peroxide: The key role of $\mathrm{pH}$ on the catalytic behavior of $\mathrm{Fe}-$ ZSM-5. Water Sci. Technol. 1997, 35 (4), 103.

16. Farhataziz, P. C.; Ross, A. B. Selected specific rates of radicals of transients from water in aqueous solutions. National Bureau of Standards, 1977, Washington, DC, NSDRS-NBS59,

17. Fisher, W. J. Oxidation of sewage with air at elevated temperatures. Water Res 1971, $5(5), 187$. 
18. Foussard, J. N.; Debellefontaine, H.; Besombes-Vailhe, J. Efficient elimination of organic liquid wastes: wet air oxidation. J. Environ. Eng. (Reston, VA, U.S.) 1989, $115(2), 367$.

19. Friedman, A. A.; Smith, J. E.; DeSantis, J.; Ptak, T.; Ganley, R. C. Characteristics of residues from wet air oxidation of anaerobic sludges. J. Water Pollu Control Fed. 1988, 60(11), 1971.

20. Fu, D., Chen, J., Liang, X., Wet air oxidation of nitrobenzene enhanced by phenol, Chemosphere, 2005, 59, 905.

21. Glass, D. C.; Gray, C. N.; Jolley, D. J.; Gibbons, C.; Sim, M. R. Health Watch exposure estimates: Do they underestimate benzene exposure? Chemico-Biological Interactions, 2005, 153-154, 23.

22. Greminger, D.C.; Burns, G.P.; Lynn, S.; Hanson D.N., King, C.J., Solvent extraction of phenol from water. Ind. Eng. Chem. Process Des. Dev. 1982, 21, 51.

23. IARC. Evaluation of the carcinogenic risk of chemicals to humans, Vol. 29. Benzene. International Agency for research on cancer, Lyon, 1982.

24. Imamura, S. Catalytic and Noncatalytic Wet Oxidation. Ind. Eng. Chem. Res. 1999, $38(5), 1743$.

25. Imamura, S.; Fukuda, I.; Ishida, S. Wet oxidation catalyzed by ruthenium supported on cerium (IV) Oxides. Ind. Eng. Chem. Res. 1988, 27 (4), 718.

26. Imamura, S; Fukuhara, M.; Kitao,T. Wet oxidation of amides, J. Chem. Soc. Jpn. $1980 b, 270$. 
27. Imamura, S.; Hirano, A.; Kawabata, N. The wet oxidation of organic compounds catalyzed by Co-Bi complex oxide. Bull. Chem. Soc. Jpn. 1982, 55 (11), 3679.

28. Imamura, S.; Nakamura, M.; Kawabata, N.; Yoshida, J.; Ishida, S. Wet Oxidation of Poly (ethylene glycol) Catalyzed by Manganese-Cerium Composite Oxide. Ind. Eng. Chem. Prod. Res. Dev. 1986, 25 (1), 34.

29. Imamura, S.; Shimai, J.; Kitao, T. wet air oxidation of dyes. Mizu Shori Gijutsu 1980a, 21, 109.

30. Imamura, S.; Tonomura, Y.; Kawabata, N.; Kitao, T. Wet oxidation of water soluble polymers. Bull Chem. Soc. Jpn. 1981, 54, 1548.

31. Imamura, S.; Tonomura, Y.; Terada, M.; Kito, T., Oxidation of oxygen containing organic compounds in water. Mizu Shori Gijutsu 1979, 20, 317.

32. Ingale, M. N.; Joshi, J. B.; Mahajani, V. V.; Gada. M. K. Waste treatment of an aqueous waste stream from a cyclohexane oxidation unit: A case study. Process Safety Environ. Protect. 1996, 74 (4), 265.

33. Joglekar, H.S.; Samant, S.D.; Joshi, J.B. Kinetics of wet air oxidation of phenol and substituted phenols Water Research, 1991,25 (2), 135.

34. Keen, R.; Baillod C. R. Toxicity to daphnia of the end products of wet oxidation of phenol and substituted phenols. Water Res. 1985, 19 (6), 767.

35. Kindzierski, W. B.; Jackson, L. G., Evaluation of Canadian drinking water guidelines using probability modeling of population exposure, 1998, 38 (6), 229. 
36. Kolaczkowski, S. T.; Beltran, F. J.; McLurgh, D. B.; Rivas, F. J. Wet air oxidation of phenol: Factors that may influence global kinetics. Process Safety Environ. Protect. 1997, 75 (B4), 257.

37. Krajnc, M.; Levec, J. On the kinetics of phenol oxidation in supercritical water. AIChE J. 1996, 421977.

38. Li, L., Chen, P., Gloyna, E., Generalized kinetic model for wet oxidation of organic compounds. AIChE Journal, 1991, 37 (11), 1687.

39. Lin, S. H.; Chuang, T. S. Combined Treatment of Phenolic Wastewater by Wet Air Oxidation and Activated Sludge. Toxicol. Environ. Chem. 1994, 44, 243.

40. Lin, S.S.; Chang, D.J.; Wang, C.; Chen, C. C. Catalytic wet oxidation of phenol by $\mathrm{CeO} 2$ catalyst - effect of reaction conditions. Water Res. 2003, 37, 793.

41. Lin, S.H.; Ho, S.J.; Wu, C.L., Kinetic and performance characteristics of wet air oxidation of high-concentration wastewater., Ind. Eng. Chem. Res., 1996, 35 (1), 307.

42. Lin, S. H.; Wu, Y. F. Catalytic wet air oxidation of phenolic wastewaters. Environ. Technol. 1996, 17 (2), 175.

43. Lovley, D. R. Potential for anaerobic bioremediation of BTEX in petroleumcontaminated aquifers. J. Ind. Microbiol., 1997, 18, 75.

44. Luck, F. A review of Industrial Catalytic Wet air oxidation processes. Catal. Today 1996, 27(1-2), 195.

45. Mantzavinos, D.; Hellenbrand, R.; Livingston, A. G.; Metcalfe, I. S. Wet Oxidation as a Pretreatment Method for Wastewaters Contaminated by Bioresistant Organics. Water Sci. Technol. 1997, 36 (2-3), 109. 
46. Merchant, K. P. Studies in Heterogeneous Reactions. Ph.D. Dissertation, Department of Chemical Technology, University of Bombay, India, 1992.

47. Metcalf \& Eddy, Inc., Wastewater Engineering: Treatment, Disposal and Reuse. (3rd. ed.), McGraw-Hill, New York 1991.

48. Mishra, V. S.; Mahajani, V. V.; Joshi, J. B. Wet Air Oxidation (Review). Ind. Eng. Chem. Res. 1995, 34 (1), 2.

49. Patterson, D. A.; Metcalfe, I. S.; Xiong, F.; Livingston, A. G. Wet Oxidation of Linear Alkylbenzene Sulfonate 2. Effect of pH. Ind. Eng. Chem. Res. 2001, 40(23), 5517.

50. Peoples, R.F.; Krishnan, P.; Simonsen, R.N., Nonbiological treatment of refinery wastewater. J. water pollution control Fed 1972, 44 (6), 2120.

51. Pintar, A.; Levec, J, Catalytic Liquid phase oxidation of phenol aqueous solutions. A kinetic investigation. Ind. Eng. Chem. Res., 1994, 33(12), 3070.

52. Portela Miguélez, J.R.; López Bernal, J.; Nobot Sanz, E.; Martínez de la Ossa, E. Kinetics of wet air oxidation of phenol. Chem. Eng. J. 1997, 67(2), 115.

53. Rivas, F. Javier; Beltrán, Fernando J.; Carvalho, Fatima; Alvarez, Pedro M. OxonePromoted Wet Air Oxidation of Landfill Leachates. Ind. Eng. Chem. Res., 2005, 44 (4), 749

54. Rivas, F. J.; Kolaczkowski, S. T.; Beltran, F. J.; McLurgh, D. B. Development of a model for the wet air oxidation of phenol based on a free radical mechanism. Chem. Eng. Sci. 1998, 53 (14), 2575. 
55. Rivas, F. Javier; Kolaczkowski, Stan T.; Beltran, Fernando J.; McLurgh, David B. Hydrogen peroxide promoted wet air oxidation of phenol: influence of operating conditions and homogeneous metal catalysts. Journal of Chemical Technology \& Biotechnology, 1999, 74(5), 390.

56. Robert, R.; Barbati, S.; Ricq, N.; Ambrosio, M. Intermediates in wet oxidation of cellulose: identification of hydroxyl radical and characterization of hydrogen peroxide. Water Res. 2002, 36(19), 4821.

57. Standard method for examination of water and wastewater, $21^{\text {st }}$ edition, 2005, Chemical Oxygen Demand (5220), 5-14.

58. Shende, R. V.; Levec, J. Wet Oxidation Kinetics of Refractory Low Molecular Mass Carboxylic Acids. Ind. Eng. Chem. Res. 1999, 38(10), 3830.

59. Shende, R. V.; Mahajani, V. V. Kinetics of Wet Oxidation of Formic Acid and Acetic. Ind. Eng. Chem. Res. 1997, 36(11), 4809.

60. Tardio, J. Low temperature wet oxidation and catalytic wet oxidation of specific organic compounds in highly alkaline solution (synthetic Bayer liquor), Ph.D. Dissertation, Department of Applied Chemistry, RMIT University, Melbourne, Australia, 2002.

61. Tardio, James; Bhargava, Suresh K.; Eyer, Sharon; Akolekar, Deepak B. Lowtemperature wet oxidation of sodium salts of low molecular weight mono- and dicarboxylic acids in synthetic Bayer liquor. Ind. Eng. Chem. Res. 2004, 43 (3), 669.

62. Thomsen, A. B. Degradation of quinoline by wet oxidation-kinetic aspects and reaction mechanisms. Water Res. 1998, 32 (1), 136. 
63. Tromans, Desmond. Temperature and pressure dependent solubility of oxygen in water: a thermodynamic analysis. Hydrometallurgy. 1998, 48(3), 327.

64. Vaidya, P. D.; Mahajani, V. V. Insight into sub-critical wet oxidation of phenol. $A d v$. Environ. Res. 2002, 6(4), 429.

65. Vicente, J., Diaz, M. Thiocyanate/phenol wet oxidation interactions. Environ. Sci. Technol. 2003, 37(7), 1457.

66. Vicente, J.; Rosal, R.; Diaz, M. Noncatalytic Oxidation of Phenol in Aqueous Solutions. Ind. Eng. Chem. Res. 2002, 41(1), 46.

67. Wakabayashi, T.; Okuwaki, A. Oxidation of coals in liquid phases. Kinetics of the base-catalyzed oxidation of acetate ion by oxygen at elevated temperatures. Bull. Chem. Soc. Jpn. 1988, 61(12), 4329.

68. Ward, D. M.; Atlas, R. M.; Boehm, P. D.; Calder, J. A., Microbial biodegradation and chemical evolution of oil from the Amoco spill, $A M B I O, 1980,9(6), 277$.

69. Willms R.S.; Balinsky A. M.; Reible D.D.; Wetzel, D. M.; Harrison D.P. Analysis of high-pressure, multiphase reactor design. Environ. Prog. 1985, 4, 131.

70. Willms, R. S.; Balinsky, A. M.; Reible, D. D.; Wetzel, D. M.; Harrison, D. P. Aqueous-Phase Oxidation: The Intrinsic Kinetics of Single Organic Compounds. Ind. Eng. Chem. Res. 1987, $26(1), 148$.

71. Willms, R. S., Reible, D. D., Wetzel, D.M., Harrison, D.P., Aqueous-phase oxidation: rate enhancement studies. Ind. Eng. Chem. Res., 1987, 26, 606.

72. Wu, Y. C.; Hao, O. J.; Olmstead, D. G.; Hsieh, K. P.; Scholze, R. J. Wet air oxidation of anaerobically digested sludge. J. Water Poll Control Fed. 1987, 59 (1), 39. 
73. Yasaka, Yoshiro; Yoshida, Ken; Wakai, Chihiro; Matubayasi, Nobuyuki; Nakahara, Masaru. Kinetic and Equilibrium Study on Formic Acid Decomposition in Relation to the Water-Gas-Shift Reaction. Journal of Physical Chemistry A, 2006, 110 (38), 11082. 


\section{Appendix A}

\section{Calculation of Oxygen Pressure Needed}

The amount of oxygen needed at given condition was calculated using the ideal gas law as follows:

$\mathrm{C}_{6} \mathrm{H}_{6}+7.5 \mathrm{O}_{2} \rightarrow 3 \mathrm{H}_{2} \mathrm{O}+6 \mathrm{CO}_{2}$

1 mole of $\mathrm{C}_{6} \mathrm{H}_{6}$ needs 7.5 mole of $\mathrm{O}_{2}$

$0.5 m l \cdots C_{6} H_{6}\left|\frac{0.879 g}{m l}\right| \frac{m o l}{78.11 g} \mid \frac{1000 \text { mmole }}{\text { mole }}=5.63 \mathrm{mmol} \mathrm{C}_{6} \mathrm{H}_{6}$

So, $5.63 \mathrm{mmol} \mathrm{C}_{6} \mathrm{H}_{6}$ needs $42.23 \mathrm{mmol} \mathrm{O}_{2}$

Using Ideal Gas Law,

$\mathrm{PV}=\mathrm{nRT}$

$\mathrm{V}=0.24 \mathrm{~L}$

Therefore, $P_{O_{2}}\left(\right.$ at $\left.220^{\circ} \mathrm{C}\right)=\frac{(0.0422) *(0.0821) *(493.15)}{0.24}=7.12 \mathrm{~atm}=104.6 \mathrm{psi}$ 


\section{Appendix B}

\section{Oxygen Solubility in Water}

In order to calculate the amount of oxygen dissolved in water the following equation that was developed by Tromans (63) was used:

$$
c_{\mathrm{aq}}=P_{\mathrm{O}_{2}} \exp \left\{\frac{0.046 T^{2}+203.35 T \ln (T / 298)-(299.378+0.092 T)(T-298)-20.591 \times 10^{3}}{(8.3144) T}\right\}
$$

Where:

$\mathrm{C}_{\mathrm{aq}}$ : Molal concentration of dissolved $\mathrm{O}_{2}\left(\mathrm{~mol} / \mathrm{kg} \mathrm{H}_{2} \mathrm{O}\right)$.

$\mathrm{P}_{\mathrm{O} 2}$ : Oxygen partial pressure (atm).

$\mathrm{T}:$ Temperature $\left({ }^{\circ} \mathrm{K}\right)$ 


\section{Appendix C}

\section{Calculation of Theoretical Amount of Carbon Dioxide Generated}

Since the benzene is not totally converted to $\mathrm{H}_{2} \mathrm{O}$ and $\mathrm{CO}_{2}$ and since acetic acid was determined in the final product, the following equations were used to calculate the total amount of carbon dioxide during the oxidation of benzene:

$\mathrm{C}_{6} \mathrm{H}_{6}+5.5 \mathrm{O}_{2} \rightarrow \mathrm{H}_{2} \mathrm{O}+4 \mathrm{CO}_{2}+\mathrm{CH}_{3} \mathrm{COOH}$

$\mathrm{CH}_{3} \mathrm{COOH}+2 \mathrm{O}_{2} \rightarrow 2 \mathrm{CO}_{2}+2 \mathrm{H}_{2} \mathrm{O}$

From the first equation it can be seen that

1 mole $\mathrm{C}_{6} \mathrm{H}_{6}$ produces 4 moles of $\mathrm{CO}_{2}$

And 1 mole of $\mathrm{C}_{6} \mathrm{H}_{6}$ produces 1 mole of $\mathrm{CH}_{3} \mathrm{COOH}$

However, it can be seen from the second equation that

1 mole of $\mathrm{CH}_{3} \mathrm{COOH}$ produces 2 moles of $\mathrm{CO}_{2}$.

The following results were obtained at $260^{\circ} \mathrm{C}$ and $1.38 \mathrm{MPa}$ of oxygen pressure

\begin{tabular}{|c|c|c|}
\hline Time & $\mathrm{mmol}_{6} \mathrm{H}_{6} / \mathrm{L}$ & $\mathrm{mmol} \mathrm{CH}_{3} \mathrm{COOH}$ \\
\hline Original sample & 3.83 & 0 \\
\hline $\begin{array}{c}\text { Final product After } \\
120 \text { min }\end{array}$ & 0.07 & 0.59 \\
\hline
\end{tabular}


From the results,

Amount of benzene oxidized $=3.83-0.07=3.76 \mathrm{mmol}$

$\therefore 3.76 \mathrm{mmol} \mathrm{C}_{6} \mathrm{H}_{6}$ produces $15.04 \mathrm{mmol}$ of $\mathrm{CO}_{2}$ and $3.76 \mathrm{mmol}$ of $\mathrm{CH}_{3} \mathrm{COOH}$

Also, the amount of $\mathrm{CO}_{2}$ produces from the oxidation of $\mathrm{CH}_{3} \mathrm{COOH}$ is

$2 *(3.76-0.59)=6.34 \mathrm{mmol} \mathrm{CO}_{2}$

$\therefore$ Theoretical Amount of $\mathrm{CO}_{2}$ produced $=15.04+6.34=21.38 \mathrm{mmol}$ 